UCRL-50027-87

Distribution Category UC-11

\title{
DISCLAIMER
}

UCRL- $-50027-87$

This report was prepared as an account of work sponsored by an agency of the United States Government. Neither the United States Government nor any agency thereof, nor any of their DE88 010367 employees, makes any warranty, express or implied, or assumes any legal liability or responsibility for the accuracy, completeness, or usefulness of any information, apparatus, product, or process disclosed, or repesents that its use would not infringe privately owned rights. Reference herein to any specific commercial product, process, or service by trade name, trademark, manufacturer, or otherwise does not necessarily constitute or imply its endorsement, recommendation, oi favoring by the United States Government or any agency thereof. The views and opinions of authors expressed herein do not necessarily state or reflect those of the United States Govertment or any agency thereof.

\section{Environmental Monitoring at the Lawrence Livermore National Laboratory Annual Report 1987}

\author{
R. C. Holland \\ D. D. Brekke
}

Manuscript date: April 1988

\section{LAWRENCE LIVERMORE NATIONAL LABORATORY University of California - Livermore, California - 94550}

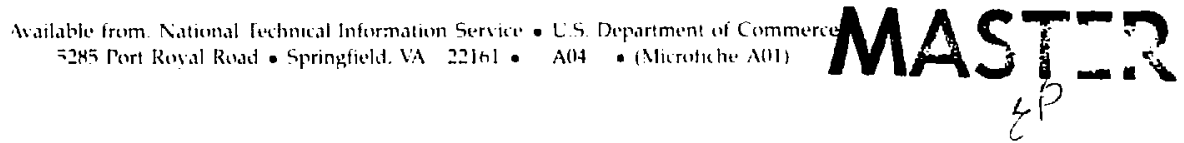




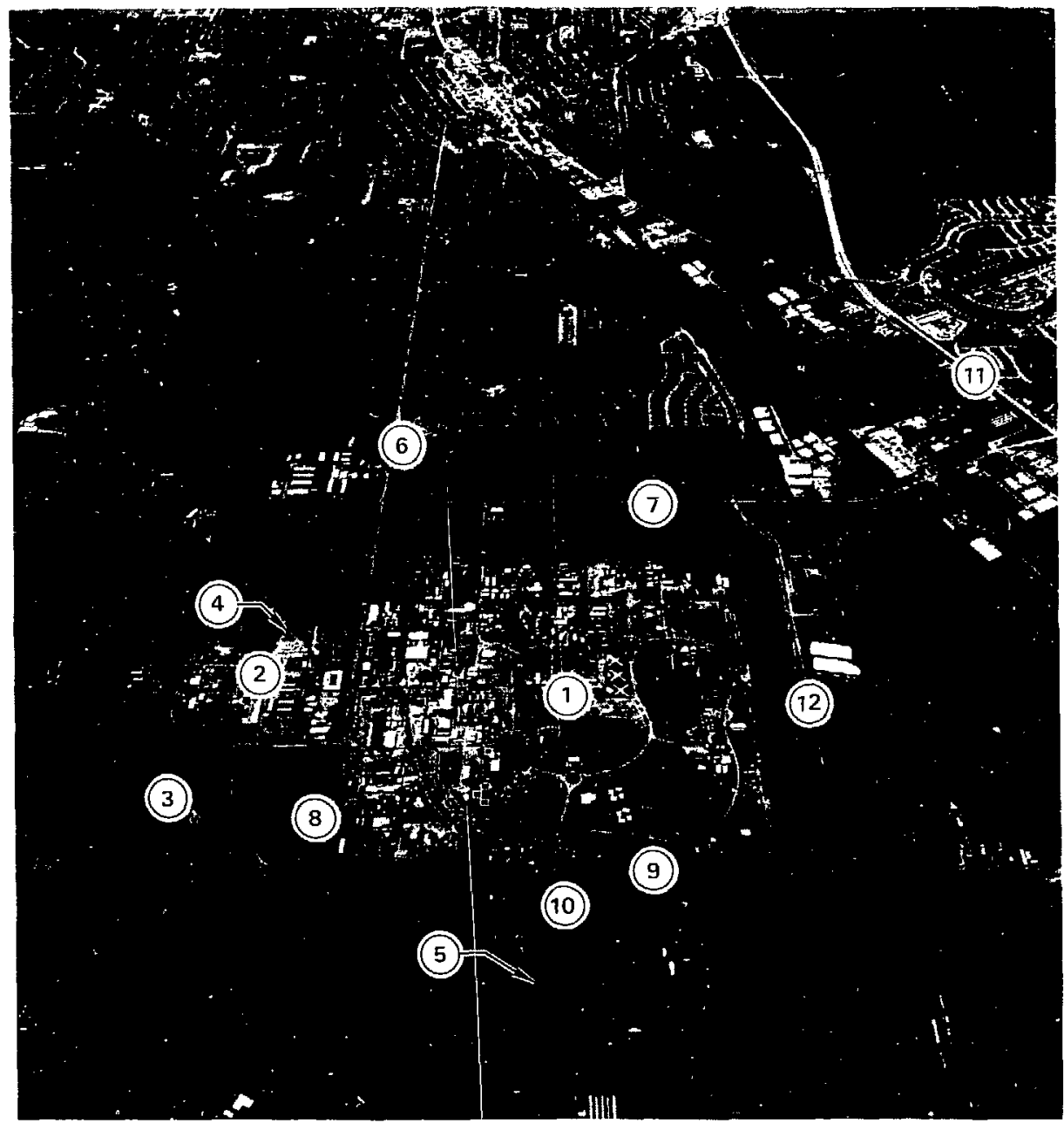

1 Lawrence Livermore National Laboratory

2 Sandia National Laboratory

3 South Bay Aqueduct

4 Arroyo Seco

5 Arroyo Las Positas

6 Nearest residential area
7 Vasco Road

8 East Avenue

9 Greenville Road

10 Lupin Way

11. Interstate 580

12 New Patterson Pass Road

Frontispiece. Lawrence Livermore National Laboratory (looking west). 


\section{Preface}

Thie report in prepared for the L:S. Department of Energy by the Environmental Ciutance and

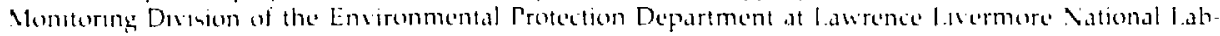
oratory: It reports the results of the Envirommental Quality Verification Group, which is responsible for environmental montering. Data are obtained through the combined efforts of the Environmental i'rotestion Department, the Nuclear Chemistry Division, and the Hazards Control Department. In addition to the authors listed. the following personnel made significant contributions to this report:

C. Aratne (1)

V. E. Arga. bright (1)

I. K. Bartun (2)

1. M. Beiriger (1)

I. F. Bover (2)

1. Braun (2)

5. 1.. Brigdon (2)

N. G. Brown (1)

T. M. Carlsen (1)

[). W. Carpenter (2)

1. A. Carter (2)

I. Chase (1)

C. E. DeGrange (2)

E. C. Draney (2)

K. I. Essary (2)

L. F. Finnie (1)

I. Garrisom (1)

C. H. Grandfield (2)

A. R. Grayson (2)

M. G. Heaton (1)

R. K. Henry (2)

F. Hoffman (2)

C. S. Jackson (2)

M. Johansen (1)

I. R. Jenkins (2)

D. L. Kendrick (2)

I. C. Kleiher (1) f. Kelly (1)

5. I. Kirst (2)

k. M. I.antu (2)

M. A. l.opuist (2)

S. C. Nactean (1)

I.. K. Mancini (?)

K. V. Marsh (2)

K. A. Narshall (2)

M. R. Marzano (2)

W. A. McConachie (2)

N. W. Nathans (2)

H. E. Pfeifer (2)

M. B. Pineda (2)

C. T. Pyles (2)

R. C. Ragaini (1)

D. Ramsey (1)

N. H. Rogers (2)

M. R. Ruggieri (1)

G. L. Seibel (2)

1. S. Silvers (2)

J. Steenhoven (2)

C. W. Sundbeck (2)

R. D. Szidon (2)

T. Torry (1)

K. Visbeck (1)

J. M. Westermark (2)

A. Yee (2)

(1) Environmental Quality Verification Personnel

(2) Administrative and Technical Support Personnel 


\section{Contents}

lint if higuren

inetrast

Sumomins

Introduction

Eoncronmerntal Momutormes

The Laborators and Adjacent siter

the lisemore site

Site 3an

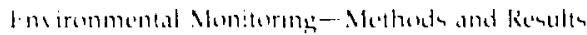

12

Mir Momburing $\quad 12$

Sivil Momitoring $\quad 1.3$

havage Monitoring

Routine Mater Monituring

lighotation and foudstuff Mhonitoring

Mill. Nomboring

Environmental Radiation Monituring _ . . . 2 20

Voise Nemitoring: $\quad \ldots .24$

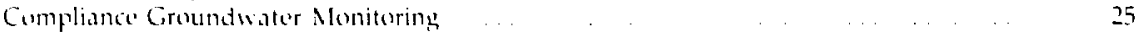

Remult ... . . . . 25

Air Monitoring $\quad \ldots \ldots \ldots \ldots \ldots \ldots \ldots \ldots \ldots$

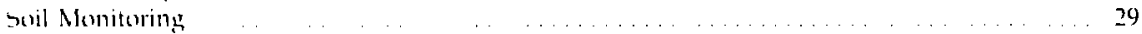

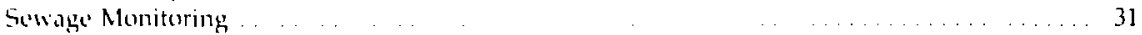

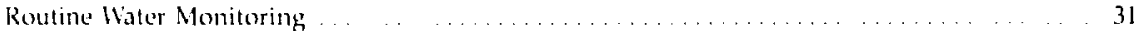

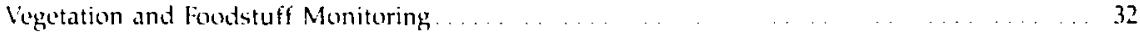

Milk Monitorin

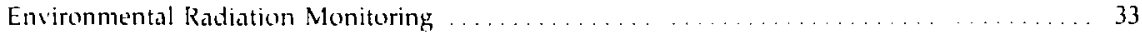

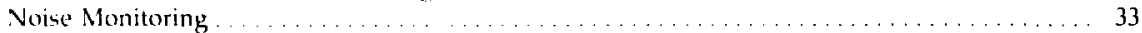

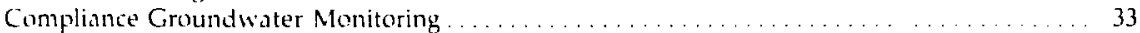

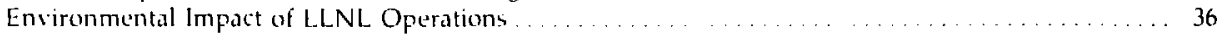

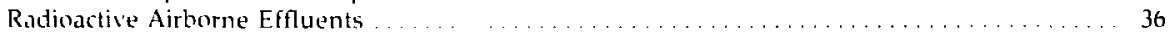

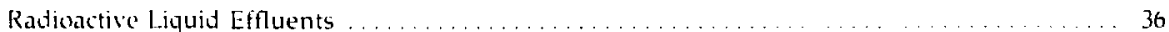

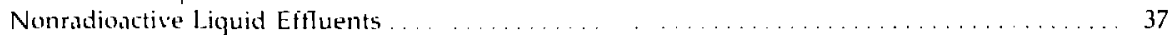

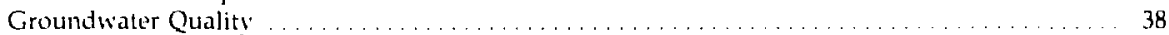

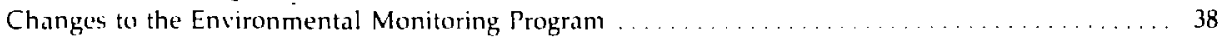

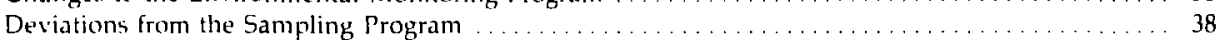

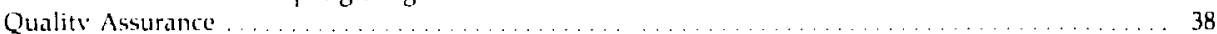

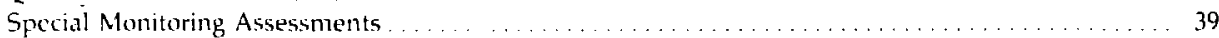

Livermore Site Groundwater Project . . . . . . . . . . . . . . . . . . . . . . . . . . 39

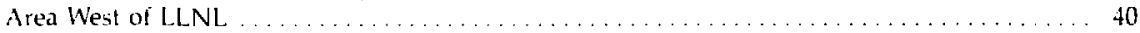

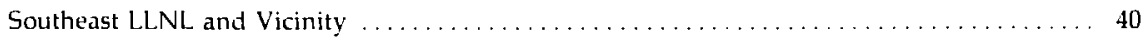

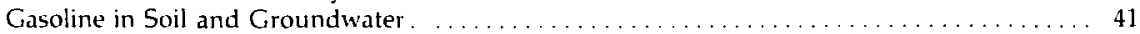

East Traffic Circle Landfill and Taxi Strip/Old Salvage Yard Areas . . . . . . . . . . . . 41

EG\&G Aerial Survey . . . . . . . . . . . . . . . . . . . . . 41

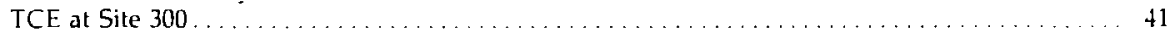

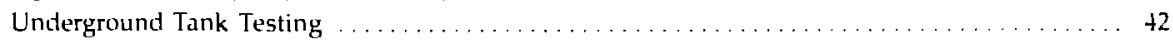

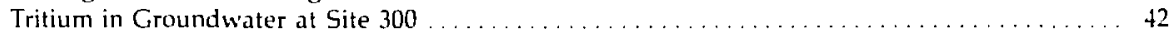

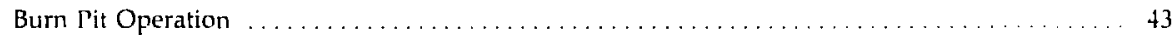

High-Explosives Wastewater Lagoons and Impoundments, Site $300 \ldots \ldots \ldots \ldots \ldots \ldots \ldots+3$

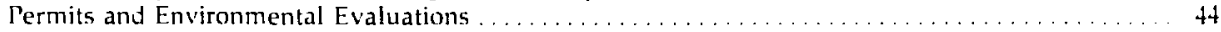

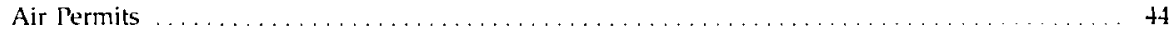

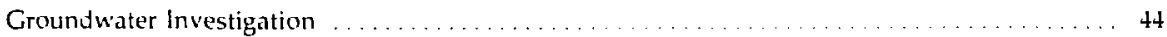

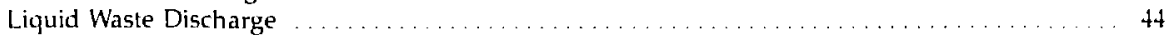


Soldit Wante I andills

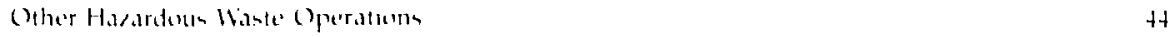

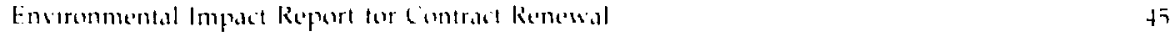

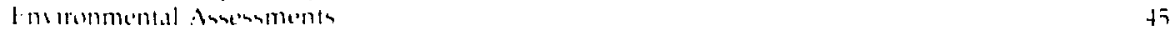

Citalions and Agremente t5

Appendice's

Appendix $A$. Data Tables ti

Appendix B. Statistical Methode 4;

Appendix C. Radiation Probetem Standards

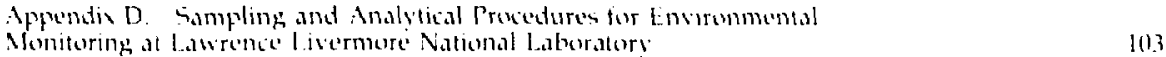

Appendak Decharge limits to the Samitary Sewer sistem
of the City at livermarc.

Appendivi: Metheds ai Dose Calculations.

Appendia G. Devations trom the Sampling Program 123

Appendia H. Quality Assuraneo Plan 127

Roterences IG? 


\section{List of Figures}

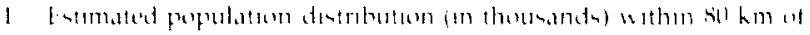
Inermole he resurn

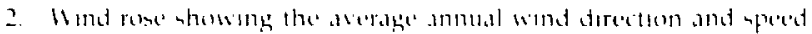
during 145 .

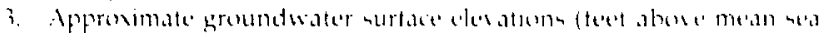
ferel), $11 \times$ and vionity

4. Topegraphy and groundwater atutate thestum. Site 3109

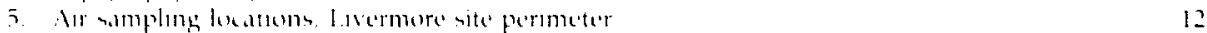

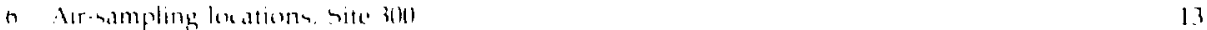

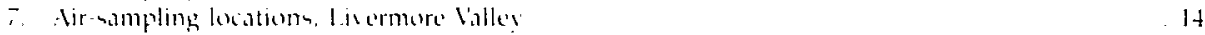

S. Suil sampling lecations, lisermore Valley 15

9. Suil-nampling locations, Situ 3ar) In

10. Water sampling locations l.vernore lalley

11. Water-sampling locations, Site 310)

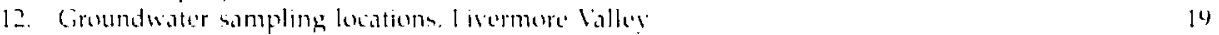

1.3. Stormwater-runoti ampling locations

14. Vigetation-ampling locations, livermore Valley 21

15. Vigetation-sampling locatums Site 300 . . . . 21

16. lociations of gamma and neutron desimeters, livermore site perimeter . . 23

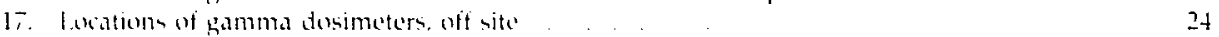

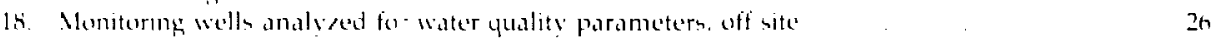

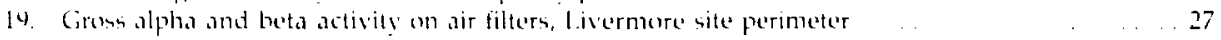

20. Grus alpha and beta activity on dir filters, Livernore Valley 27

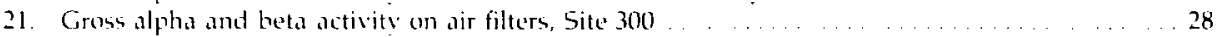

22. Concentration of beryllium on air filters: (a) livermore site and

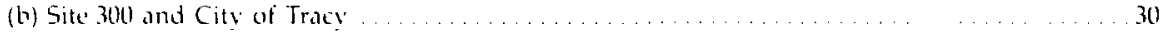

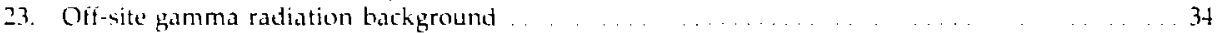

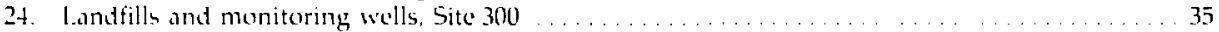




\title{
Environmental Monitoring at the \\ Lawrence Livermore National Laboratory Annual Report 1987
}

\begin{abstract}
This report documents the results of the Environmental Monitoring Program at the Lawrence Livermore National Laboratory (LLNL) for 1987. To evaluate the effect of LL.NL operations on the local environment, measurements were made of direct radiation and a variety of radionuclides and chemical pollutants in ambient air, soil, sewage effluents, surface water, groundwater, vegetation, foudstuff, and milk at both the Livermore site and nearby Site 300. This report was prepared to meet the requirements of Department of Energy: Order 5484.1 . Evaluations were made of LLNL's compliance with all applicable guides, standards, and limits for radiological and nonradiological releases to the environment. The data indicate that the only releases in excess of applicable standarts were four releases to the sanitary sewer. LLNL operations had no adverse impact on the environment during 1987.
\end{abstract}

\section{Summary}

The Environmental Quality Verification Group (EQVG) at the Lawrence Livermore National Laboratory (LLNL) conducts an environmental monitoring program to verify the effectiveness of control measures and to assess the potential impacts to the environment resulting from LLNL operations. Potential hazardous emiscions include tritium, plutonium, uranium metals, solvents. and common laboratory chemicals. This report, prepared in compliance with U.S. Department of Energy (DOE) Order 5484.1, presents the environmental monitoring data for the Livermore site and nearby Site 300, LLNL's high-explosives testing site.

To evaluate the impact of LLNL operations on the environment, measurements were made of direct radiation and a variety of radionuclides and chemical pollutants in ambient air, soil, surface and groundwater, vegetation and foodstuff, and sewage effluents. In addition, evaluations were made of LLNL's compliance with regulations, guides, and orders for environmental monitoring and concentrations of pollutants in environmental media. Measurements and evaluations are summarized below:

\section{Air Monitoring}

All measurements of airborne pollutants at the Iivermore site perimeter, Livermore Valley: and Site 300 sampling locations were well below. regulatory limits in 1987.

Location 15 showed the highest annual average ${ }^{234} \mathrm{Pu}$ concentration at $1.00 \times 10^{17} \mu \mathrm{Ci} / \mathrm{mL}$. This is approximately twice the highest annual average observed in 1986, but still represents only $0.05 \%$ of the regulatory limit. Location 15 also showed the highest annual average ${ }^{23 x} \mathrm{U}$ concentration at $1.03 \times 10^{4} \mu \mathrm{g} / \mathrm{m}^{3}$, which is only slightly above the highest annual average observed in 1986 . This value represents $0.03 \%$ of the regulatory limit. No gamma-enitting radionuclides were detected above hackground levels. Location 15 also showed the highest annual average concentration of beryllium at $5.1 \times 10^{\circ} \mu \mathrm{g} / \mathrm{m}^{3}$. 
wheth in slightly lese than the highest anmusl a. erage obererved in losio. Thes value represents

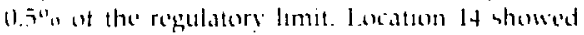
the highent annual average tritium concentration

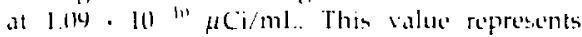
17.189"in of the regulatory limit and is approsimalely. one-half of the highest 1986 value.

Gross radionetivity medsurements are made for the purpose of screening and trending airlorme radreactivity saldes. The gross alpha and gross beta values showed no significant tremets in 1987.

The total amount of tritiun released to the atmosphere by I.LNL in 1987 was $2731 \mathrm{Ci}$. approximately $1329 \mathrm{Ci}$ in the form of tritiated water. An additional $370 \mathrm{Ci}$ of tritiated water were released by Sandia National 1.aboratories. Livermore (SNI.l). The tetal yuantity of ${ }^{1 /} \mathrm{N}-{ }^{12} \mathrm{O}$ released in 1967 was 48 C $i$ at the livermore site and $14 \mathrm{Ci}$ at Site 300 . The maximum off-site dose attributable to these airborne radianative enissions rias 0.08 nuren, which is lar less than the Envirommental Protection Agency (EPA) limit of $25 \mathrm{mrrm} / \mathrm{s}$

\section{Soil Monitoring}

The concentrations of ${ }^{234} \mathrm{Pu}$ in the soil of the Livermore Valley are similar to those observed in previous years, with the exception of elevated values in samples taken at the Livermore Water Reclamation Plant (LWRD). The highest value of $526 \times 10^{4} \mu \mathrm{Ci} / \mathrm{g}$ represents $4.2 \%$ of the proposed EPA soil standard for unrestricted use of $12 \times 10^{\circ} \mu \mathrm{Ci} / \mathrm{g}$. The remaining areas reflect world-wide fallout and naturally occurring concentrations of nuclides.

The soil samples collected at Site 300 show that greater-than-background concentrations of ${ }^{2} \mathrm{k} \mathrm{U}$ are limited to isolated regions near the firing tables. The highest value of $149 \mu \mathrm{g} / \mathrm{g}$ is typical of previous y'ars' data.

During 1987, a number of special assessments were performed that involved the analyses of soil samples. These assessments were done to investigate the contamination, if any, at Site 300 (landfills and an environmental test facility) and at LLNL (a gasoline tank leak, an inactive landfill, and potential groundwater contamination sources). The soil samples were analyzed for various contaminants (metals, gasoline, chlorinated hydrocarbons, ridioactivity, etc.) as appropriate for the specific assessment. A summary of each of these investigations is presented in the "Special Monitoring Assessments" section of this report.

\section{Water Monitoring}

\section{Compliance Groundwater Monitoring}

Some groundwater monitoring wells near land. tills at Site 300 showed sharply elevated concentrations of tritiated water. The highest value measured was $+10^{\prime} \mu \mathrm{Cj} / \mathrm{nul}_{\text {; }}$ this value is above the California Department of Health Services (DOMS) drinking water limit (State of California, 1977), but was found in an ayuifer that is not used for water supplies. Traces of halogenated hydrocarbons were detected in wells downgradient of this area wat in groundwater downgradient from another landfill at Site 300. The highest trichlorocthylene value observed during routine monitoring in 1987 was 113 pph in the Bidg. 817 area. Higher values have been observed in areas undergoing special investigations. Nitrate levels in 12 monitoring wells were ahove DOHS drinking water limits (State of California, 1977). These levels are thought to be naturally occurring.

During 1987, a number of spectial assessments were performed that involved the analyses of groundwater samples for various contaminants as appropriate for the specific assessment (see the "Special Monitoring Assessments" section of this report).

\section{Routine Water Monitoring}

The amount of tritiated water discharged into the sanitary sewer system in 1987 was $1.4 \mathrm{Ci}$. The discharge of ${ }^{274} \mathrm{Pu}$ was $6.9 \times 10^{+} \mu \mathrm{Ci}$, a 46 -fold increase over the amount released in 1986 but still less than $0.01 \%$ of the DOE annual discharge limit. The elevated ${ }^{237} \mathrm{Pu}$ was the result of an inadvertent release to the Livermore site sewer system during May 1987. The exact circumstances of the release are still under investigation.

Tritium analyses were also made on water samples collected from monitoring wells near the LWRP. These analyses, begun in 1977, are made to determine the extent to which low levels of tritium in the LWRP effluent may be migrating into groundwater. As was found during earlier surveys, the highest tritium values $\left(8.2 \times 10^{7} \mu \mathrm{Ci} / \mathrm{mL}\right)$ were detected in test wells downgradient from the I.WRP near Arroyo Las Positas. Since the LWRP effluent has not been discharged to the Arroyo Las Positas since 1980, the primary means of tritium movement to nearby groundwater has been eliminated and the concentrations observed are generally decreasing. Tritium soncentrations observed in local water supply wells in 1987 were generally the same as in previcus years and reflect background levels of tritium. 
Water samples collected in the Livermore Val. lev and at site 300 exhibit gross beta and tritium activitles wathin the ranges previously observed in these sampling areas. Six water sanple's from Site 300 showed ahove-average levels of gross alpha activity $\left(32,25,21,20,18\right.$, and $7 \times 10^{4} \mu \mathrm{Ci} / \mathrm{ml}$ ). This activity has been found to be naturally occurring uranium at concentrations well within those specified by DOE (U.S. Department of Energy: 1987 a) and helow the health advisory level recommended by the DOHS.

\section{Vegetation and Foodstuff Monitoring}

Tritium levels found in the Liverntere Valley and Site 300 vegetation were generally comparable to those observed in 1986 . Vegetation collectest from a landfill area at Site 300 contained substantially higher levels of tritium (up to $2.84 \times 10^{\circ}$ $\mu \mathrm{Ci} / \mathrm{mL}$ of recowered water) than other a:eas, a phenomenon also retorded in 1985 and 1986 . This area is under investigation for soil and groundwiter tritium contamination, as described in the "Special Monitoring Assessments" section of this report.

As a means of evaluating the possible impact of LLNL effluents on locally grown foodstuff, the tritium content of Livermore Valley wines was compared with values from other California and European wines. The ritium levels in Valley wines are comparable to those found in European wines, but are somewhat higher than those in other California wines.

Honey produced in the Livermore Valley contained tritium levels comparable to those found in honey from neighboring areas. Milk samples from goats pastured within $5 \mathrm{~km}$ of LLNL showed no impact attributable to L.LNL activities.

\section{Environmental Radiation Monitoring}

The maximum potential radiological impact from LLNL operations during 1987 , as indicated

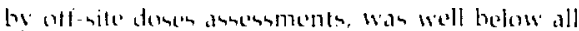
appliable regulatory limits; moreover it was substantialiv less than the dose received from back ground radiation.

The 1987 alerage external gamma-radiation "fence-post") doses mensured at the livermore site perimeter and off-site locatims were 65 mrem and tot mrem, respectively, indicating no significant difference botwere the average perimeter dose and the average off-site dose (which is considered to represent batkground). In addition, these doses are consistent with the 1986 results, which indicates there was no significant external dose to any member of the public in the vicinity bI I.J.NI.

The annual derage neutron dose at the Livermore site perimeter was $5.0 \mathrm{mrem}$. The neutron dose nodar the south perimeter showed slightly elevated levels for the second yuarter of $1987.5 .7 \mathrm{mrem}$. This was caused hy the operation of a $1-\mathrm{MeV}$ neutron generator in Bldy. 212 during that time.

The maximum combined inhalation/submersion duses from airtorne emissions at the site perimeter and to the nearest resident were 0.08 nirem and 0.06 mrem, respectively. This is well below the ECA's limit of $25 \mathrm{mrem} / \mathrm{y}$ for this pathway. The calculated committed $\left(50-y^{\prime}\right)$ effective dose equivalent to the maximally exposed member of the public from all sources and pathwavs during 1987 was 0.3 niren. The $D O E$ radiation protection limit to the public is $100 \mathrm{mrem} / \mathrm{y}$. For comparison, the average resident of the Livermore Valley received a dose of approximately 100 mrem from natural background radiation during this same time period. The estimated collective effective dose equivalent to the population wtithin $80 \mathrm{~km}$ ( 50 miles) of LLNL was 0.52 person-rem during 1987.

The doses presented above were calculated using conservative assumptions; they are not the doses actually received by anyone. The doses received by any actual individual would be consid. erably less. Thus these maximum credible toses show that LLNL operations had no significant impact on the public during 1987. 


\section{Introduction}

The Environmental Quality Verification Group (E) QV G) at the l.awrence livernore National l aboratory (LINI.) conducts an environmental monitoring program to verify the effectiveness of control measures and to assess the potential impacts to the enviromment and public resulting from op. erations at l.L.NI. and. incidentally, from Sandia National Laboratories, Livermore (SNILL). Poter tial hayardous emissions include tritium, uranium, plutonium, metals, solvents, and common laboratory themicals. Because of its proximity to the liv' ermore site and the extensive environmental monitoring program at I.I.NI., SNI.I. does not duplicate l.l.NL's program. This report presents the environmental monitoring data for botin laboratorie's and Site 300): however, the ratiological dose assessment. investigations, environmental assessments, and permitting artivities have been perforned for livermore site and Site 300 emissions only.

\section{Environmental Monitoring}

Strict effluent-control programs that emphasize controlling effluents at the source have been in effect at LLNL and SNLL since operations began. The data collected by the EQVG are used for three purposes: (I) to assess the effectiveness of these control measures at the Livermore site, Site 300, and SNL_L: (2) to assess compliance with applicable standards; and (3) to estimate the impact of these operations on the environnent. Sensitive monitoring equipment is used that can detect radioactive and nonradioactive pollutants at environmental background levels. The program include's the collection and analysis of air, soi". water. sewage effluent, vegetation, foodstuffs, and milk samples. In addition, environmental radiation levels are measured at numerous locations in the vicinity of LLNL using gamma and neutron dosimeters.

Each spring, LLNL reports the results of environmental monitoring for the previous year, noting significant changes in either the scope of the program or the levels of effluents. This report is prepared in compliance with DOE Order No. 5484.1. Environmental Protetion, Safolli, and Health Protection luformation Reporting Reifuireme'nts (U.S. Department of Energ!, 1981).

Apfendix $A$ is a tabulation of 1987 environmental monitoring data. Radioactivity values are tabulated with the associated counting uncertamtics at the $2 \pi$ (4)5"w confidence) level. Sec Appendix B for a discussion of the statistical methods used to calculate these chata. The impact on the publit caused by releases of radionctive materials in the vicinity of I I N1 is assessed based on effluent discharges and medsurements of envirommental media. Doses are colculated at the points of maximum exposure in an area accessible to the puthic and to the (otal population residing within an 80 km (50)-mile) radius of l.I.NL. Doses from natural sources are also reported for comparison. These doses are compared with radiation protection standarts in Appendix C. This assessment is made for I i.Nl effluents only. The dose assessment and other detailed environmental information for SNLL. are contained in the 1987 Lnvirnmental Monitoriug Roporl, Sandia Vational Laburatorits, Lievmore (Devlin. 1988).

\section{The Laboratory and Adjacent Sites}

LLNL is located about $64 \mathrm{~km}$ ( 39 miles) cast of San Francisco, California, in the Livermore Valley of eastern Alameda County, approximately $5 \mathrm{~km}$ (3 miles) east of the City of Livermore. SNLL is located adjacent to LLNL's southern boundarv. Nearly 6 million people live within $80 \mathrm{~km}(50$ miles) of LLNL (see Fig. 1); of these, approximately 54000 live in Livermore.

LLNL, operated by the University of California for the United States Department of Energy (DOE), was established in 1952 to conduct nuclear weapons and magnetic fusion energy research. Since then, other major programs have been atded, including laser fusion and laser isotope separation, biomedical and euvironmental sciences, and applied energy technology. These programs require research in such basic scientific disciplines as chemistry and materials science, computer science and technology, engineering, and physics LLNL also carries out a variety of projects for other federal agencies.

Much of LLNL's materiais testing and highexplosives ( $(\mathrm{HE})$ diagnostic work is conducted at Site 300 , located in the sparsely populated hills of the Diablo sange, $24 \mathrm{~km}$ (15 miles) southeast of Livermore. Figure 1 show's the location of the Liv. ermore site with respect to its surrounding areas. In 1987. LLNL employed approximately 8200 people. 


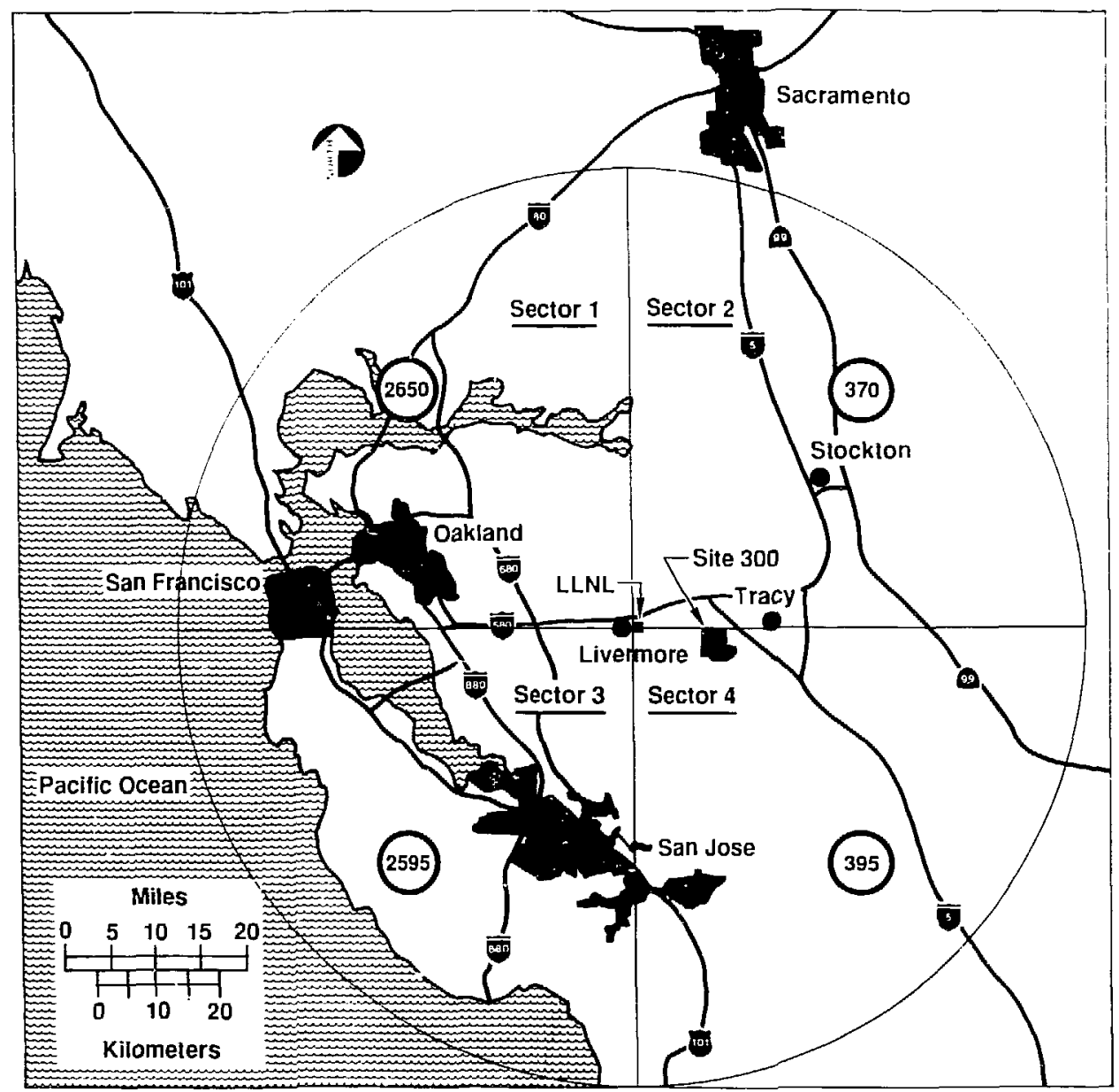

Figure 1. Estimated population distribution (in thousands) within $80 \mathrm{~km}$ of Livermore, by secinrs.

SiNLL is operated by AT\&T Technologies, Inc., under contract to DOE. SNLL's primary mission is research and development associated with nuclear weapons systems engineering and related national security tasks. In addition, it has energ: programs involving combustion, fusion, and solar research, and conducts research and development projects for other federal agencies. In 1987, SNLL employed approximately 1100 people.
LLNL_ and SNLL are separate facilities, with different DOE operations headquarters and different local management. Some of SNLL's monitoring data are included here because the two sites are adjacent and they conduct similar operations. The complete report of environmental monitoring data for SNLL is published in the 1987 Enironmental Monitoring Repur, Santia Vational Laboratories, Litermere' (Devlin. 1988). 


\section{The Livermore Site}

I.I.NI S livernore ste is located in the south. eastern portion of the Livermore Valley, whith is an tast-west oriented topographic and structural depression within the Diablo Range of the California Coast Range Province. The Livermore Valley forms an irregularly shaped lowland area approximately $26 \mathrm{~km}$ ( 16 miles) long, eust to west, and averages $11 \mathrm{~km}$ (7 miles) wide, north to south. The floor of the valley slopes to the west from an elevation of approximately $200 \mathrm{~m}(660 \mathrm{ft})$ at the eastern end to approximately $90 \mathrm{~m}(295 \mathrm{ft})$ at its drainage outlet, which is located near the south. western corner.

The climate of the Livermore Valley is characterized by mild, rainy winters and warm, dry summers. The mean annual temperature is $12.5^{\circ} \mathrm{C}$ $\left(59^{\circ} \mathrm{F}\right)$; the normal seasonal temperature range is defined by nighttime winter low's in the vicinity of $0^{\circ} \mathrm{C}\left(32^{\circ} \mathrm{F}\right)$ and summer daytime highs around $38^{\circ} \mathrm{C}\left(100^{\circ} \mathrm{F}\right)$. Annual wind data are given in Fig. 2. Prevailing winds are from the west and southwest from April through September; during the remainder of the year, wind directions are variable. Both rainfall and wind exhibit a strong seasonal pattern. Mlost of the precipitation occurs between October and April, with very little rainfall during the warmer months of the year. The highest and lowest annual rainfalls on record are $782 \mathrm{~mm}$ (30.8 in.) and $138 \mathrm{~mm}$ (5.4 in.). Rainfall at the Livermore site for 1987 was $315 \mathrm{~mm}$ (12.4 in.). Previously, rainfall was calculated for a water year running from October 1 to September 30 of the following year. For simplicity, we are now reporting by calendar year. The last three months of 1986 (which were not included in the 1986 water year) had rainfall of $26.4 \mathrm{~mm}$ (1.04 in.).

Surface drainage is by westward-flowing intermittent streams (arroyos) that merge in the west end of the valley to form the southwardflowing Arroyo de la Laguna, a tributary to the Alameda Creek drainage system. Winter flows that are not captured as groundwater recharge flow out of the southwestern corner of the valley and eventually enter San Francisco Bay by way of Alameda Creek. Surface water bodies near the Livermore site and SNLL include the South Bay Aqueduct, which runs from northeast to southwest, $0.2 \mathrm{~km}(0.1 \mathrm{miles})$ to the southeast of the Livermore site; the treatment tanks and reservoir of the Patterson Pass water treatment facility, about $1.2 \mathrm{~km}(0.7$ miles) east of the Livermore site; Frick Lake, an area of enclosed drainage $4 \mathrm{~km}(2.4$ miles) north of the livernore site, where winter stormflow's accumulate in an intermittent pond; and the Springtown pond, an artificial decorative pond maintained in a community recreation area $2.6 \mathrm{~km}$ (1.6 miles) northwest of the Livermore site. l.ake Del Valle, a water storage reservoir $8 \mathrm{~km}(4.9$ miles) south of the Livermors site, provides aquatic recreation (swimming, hoating, and fishing), as does the Shadow Cliffs Regional Park, $11 \mathrm{~km}$ (6.7 miles) to the west. Lake Isabel, $9 \mathrm{~km}$ ( 4.9 miles) to the southwest, is a fee-for-fishing area. Both Lake isabel and the Shadow Cliffs facility are excavations produced by gravel quarry operations, which continue to develop additional pits in the same general area. Both the Livermore site and SNLL normally receive their treated water supply from the Hetch Hetchy Aqueduct (which supplies San Francisco), located $11 \mathrm{~km}$ (b.7 miles) southwest of Livermore.

The hydrogeology and groundwater occurrence and movement in the vicinity of the laboratories have been the subjects of several recent and continuing investigations (see the "Compliance Groundwater Monitoring" subsections and the "Special Monitoring Assessments" section of this report). More detailed discussions of these investigations can be found in Stone et al., 1982; Stone and Ruggieri, 1983; Carpenter et al., 1984; and Weiss Associates, 1985. The remainder of this subsection has been summarized from the reports of these investigations and from data supplied by Zone 7 of the Alameda County Flood Control and Water Conservation District, the agency responsible for groundwater management in the Livermore Vailey basin.

The Livermore Valley is bound in the east by the Altamont Hills, where the miocene-age Neroly and Cierbo Formations and rocks of the Late Cretaceous Great Valley sequence are exposed. Within the valley, lacustrine and fluvial valley fill deposits occur to depths in excess of $1 \mathrm{~km}$. The oldest of these is the Lower Livermore Formation of late Tertiary age, a hard, locally lithified, predominantly fine-grained sedimentary sequence that is exposed in the hills south of the Livermore Valley and is encountered beneath the Livermore and SNLL sites at depths ranging from $7 \mathrm{~m}(23 \mathrm{ft})$ in the east to $119 \mathrm{~m}(389 \mathrm{ft})$ in the west. Above the Lower Livermore Formation are the heterogeneous, unconsolidated da."'vial sediments of the Pleistocene-age Upper Liv':2rmore Formation, which consist of complexly interbedded layers of poorly sorted clay, silt, sand, and gravel. The late Pleistocene and Holocene-age alluvial 


\section{Livermore}

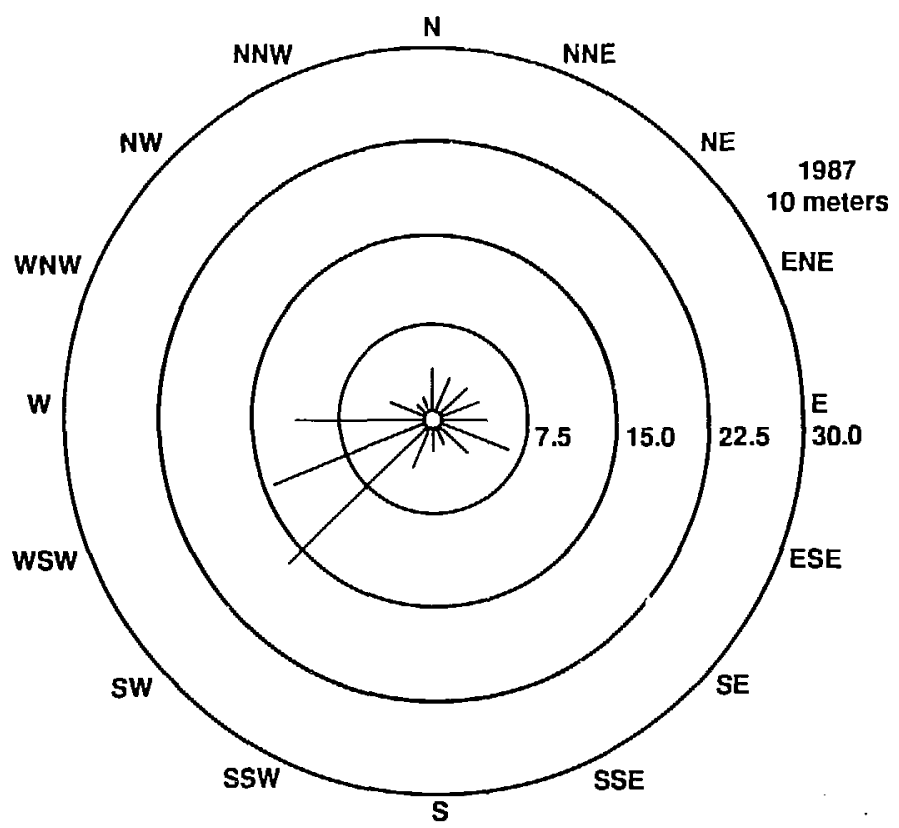

Livermore 10 meters 1987

\begin{tabular}{|c|c|c|c|c|c|c|c|c|c|c|c|}
\hline \multirow[b]{2}{*}{ Direction } & \multirow[b]{2}{*}{$0-2$} & \multirow[b]{2}{*}{$2-3$} & \multicolumn{8}{|c|}{ Average annual percent frequency of wind direction vs, wind speed $(\mathrm{m} / \mathrm{s})$} & \multirow{2}{*}{$\begin{array}{c}\text { Average } \\
\text { speed } \\
\text { (m/s) }\end{array}$} \\
\hline & & & $3-5$ & $5-7$ & 7.9 & $9-11$ & $11-16$ & $10-24$ & $>20$ & Total & \\
\hline $\mathbf{N}$ & 1.4 & 0.4 & 0.8 & 0.8 & 0.6 & 0.2 & 0.0 & 0.0 & 0.0 & 4.3 & 4.3 \\
\hline NNE & 1.3 & 0.8 & 1.1 & 0.4 & 0.2 & 0.0 & 0.0 & 0.0 & 0.0 & 3.9 & 3.2 \\
\hline NE & 1.5 & 1.1 & 1.2 & 0.1 & 0.0 & 0.0 & 0.0 & 0.0 & 0.0 & 3.9 & 2.4 \\
\hline ENE & 1.7 & 1.0 & 1.0 & 0.3 & 0.0 & 0.0 & 0.0 & 0.0 & 0.0 & 4.0 & 2.5 \\
\hline E & 3.3 & 0.7 & 0.3 & 0.1 & 0.0 & 0.0 & 0.0 & 0.0 & 0.0 & 4.3 & 1.6 \\
\hline ESE & 5.8 & 0.5 & 0.0 & 0.1 & 0.1 & 0.0 & 0.0 & 0.0 & 0.0 & 6.5 & 1.4 \\
\hline SE & 3.4 & 0.3 & 0.1 & 0.0 & 0.0 & 0.0 & 0.0 & 0.0 & 0.0 & 3.9 & 1.4 \\
\hline SSE & 2.0 & 0.2 & 0.1 & 0.1 & 0.0 & 0.0 & 0.0 & 0.0 & 0.0 & 2.4 & 1.4 \\
\hline $\mathbf{S}$ & 2.3 & 0.2 & 0.1 & 0.0 & 0.0 & 0.0 & 0.0 & 0.0 & 0.0 & 2.7 & 1.5 \\
\hline SSW & 2.6 & 1.0 & 0.6 & 0.2 & 0.0 & 0.0 & 0.0 & 0.0 & 0.0 & 4.4 & 2.1 \\
\hline $\mathbf{s W}$ & 3.9 & 3.7 & 6.2 & 2.8 & 0.6 & 0.0 & 0.0 & 0.0 & 0.0 & 17.2 & 3.5 \\
\hline WSW & 4.2 & 4.1 & 4.9 & 1.0 & 0.1 & 0.1 & 0.0 & 0.0 & 0.0 & 14.4 & 3.0 \\
\hline$w$ & 2.4 & 2.7 & 5.1 & 0.9 & 0.0 & 0.0 & 0.0 & 0.0 & 0.0 & 11.2 & 3.2 \\
\hline WNW & 1.5 & 0.8 & 1.0 & 0.5 & 0.0 & 0.0 & 0.0 & 0.0 & 0.0 & 3,8 & 2.9 \\
\hline NW & 1.5 & 0.3 & 0.1 & 0.0 & 0.0 & 0.0 & 0.0 & 0.0 & 0.0 & 1.9 & 1.5 \\
\hline NNW & 1.4 & $0 . n$ & 0.3 & 0.2 & 0.1 & 0.0 & 0.0 & 0.0 & 0.0 & 2.2 & 2.3 \\
\hline Calm & - & - & - & - & - & - & - & - & - & 9.1 & - \\
\hline Total & 40.2 & 18 & 23 & 7.5 & 1.7 & 0.4 & 0.1 & 0.0 & 0.0 & 100.0 & 2.5 \\
\hline
\end{tabular}

Winds are based on 15-min averages.

Figure 2. Wind rose showing the average wind direction and speed during 1987. 
deposits that form the uppermost sequence of val lev sodiments are virtually identical to the Upper Livermore formation.

The Lisermore Formation (and owerlying alluvial deposits) contains the aculufers of the Liv'ermore Valley groundwater basin, and is an important water-bearing formation. During 1987, approximately 10 million cubic meters ( 8500 acre-ft) of groundwater were evtracted for domestic and agricultural use in the livermure Valley. Mlost of this volume was pumped from municipal supply wells in Pleasanton and Livermore. In 1987, groundwater use represented approximately $27 \%$ of total water tonsumption in the livermore Valley:

Natural recharge occurs primarily along the fringes of the hasin and through the arroyos during periods of winter flow: Zone 7 conducts artificial recharge as needed to maintain groundwater levels. This is done by releasing water from Lake Del Valle or the South Bay Aqueduct into arroyo channels in the eastern portion of the valley: Groundwater flow in the valley generally moves toward the central east-west axis of the valley and then westward through the central basin. Groundwater flow in the basin is generally assumed to be primarily horizontal, although a significant vertical component probably exists in fringe areas and under localized sources of recharge.

Beneath the Livermore site, the depth to water table varies from about $43 \mathrm{~m}(140 \mathrm{ft})$ to $8 \mathrm{~m}$ (25 ft) according to observations during 1987. Figure 3 show's a contour map of water table elevations (feet ahove mean sea level) for April, 1987. Although water table elevations vary with seasonal and year-to-year variations in both natural and artificial recharge the qualitative patterns shown in Fig. 3 are generally maintained. At the eastern edge of the Livermore site, groundwater gradients (change in elevation per unit of horizontal distance) are quite steep. but under mest of the site and farther to the west, the contours flatten out to a gradient of approximately 0.003 . Groundwater flow under the northem and westem portions of the site is generally westward. Under the southeast corner of the site, there is an apparent groundwater depression, a phenomenon that has been further investigated; a detailed description of findings to tate is provided in Dresen and Nichols (1986). Aquifer tests on monitoring wells in the vicinity of the Livermore site indicate that the hydraulic conductivity of the permeable sediments ranges from 1 to $16 \mathrm{~m} / \mathrm{day}$ (Weiss Associates, 1985). This, in combination with the observed water table gradi- ints, vielde groundwater velocity estimates of 5 to $9(1 \mathrm{~m} / \mathrm{y}$. The range in the we values reflects the heterogermety typical of the more permeable of the alluvial sediments that underlie the area.

On the livermore site, storm water is channeled through storm sewers designed to accommodate a 10-y flow. Open ditches are used in undeveloped areas of the site. The Arroyo las Pusitas flow is channeled north to the northeast corner of the site, and then west along the north perimeter to an outlet at the northwest corner. This sutlet, which also constitutes the main pathway for the site's surface drainage (storm and irrigation runoff), runs north to the Western Pacific tracks, then west where it joins the Arroyo Seco. The main channel of the Arrovo Seco crosses the conter of the SNLL site from the southeast and then the southwest corner of the Livermore site.

The combined sewage from tha Livermore site and SNLL is discharged into the City of Livermore's sanitary sewer system and processed at the Livermore Water Reclamation Plant (LWRP). As part of the Livermore-Amador Valley Wastewater Management Program, the treated sanitary wastewater is transported out of the valley through a pipeline and discharged into the San Francisco Bay: A small portion of the treated affluent from the LWRP is used for summer irrigation of nearby livermore city property.

The developed portion of the livermore site occupies an area of $2.54 \mathrm{lim}^{2}\left(1.0\right.$ miles$\left.^{2}\right)$; additional land has recently been acquired for security' buffer zones on the west and north sides of the existing site, increasing the total area to $3.28 \mathrm{~km}^{2}$ (1.3 miles $\left.{ }^{2}\right)$. The developed portion of the SNLL site occupies an area of $0.75 \mathrm{~km}^{2}\left(0.2\right.$ miles $\left.{ }^{2}\right)$; additional lands are being acquired for security buffer zones on the east and west sides of the SNLL site. There is a business park to the southwest of the Livermore site and one to the north. Although most of the land adjacent to L.LNL is presently in agricultural use (grazing and forage crops), much of it has been rezoned for industrial use and development is anticipated in the near term. The nearest residential area is $0.8 \mathrm{~km}$ ( 0.5 miles) from the west perimeter of the developed portion of the Livermore site.

\section{Site 300}

Site 300 , l.LNI's HE testing site, is located $24 \mathrm{~km}$ (15 miles) east of the Livermore site in the Altamont Hills of the Diablo Range. It occupies an area of 


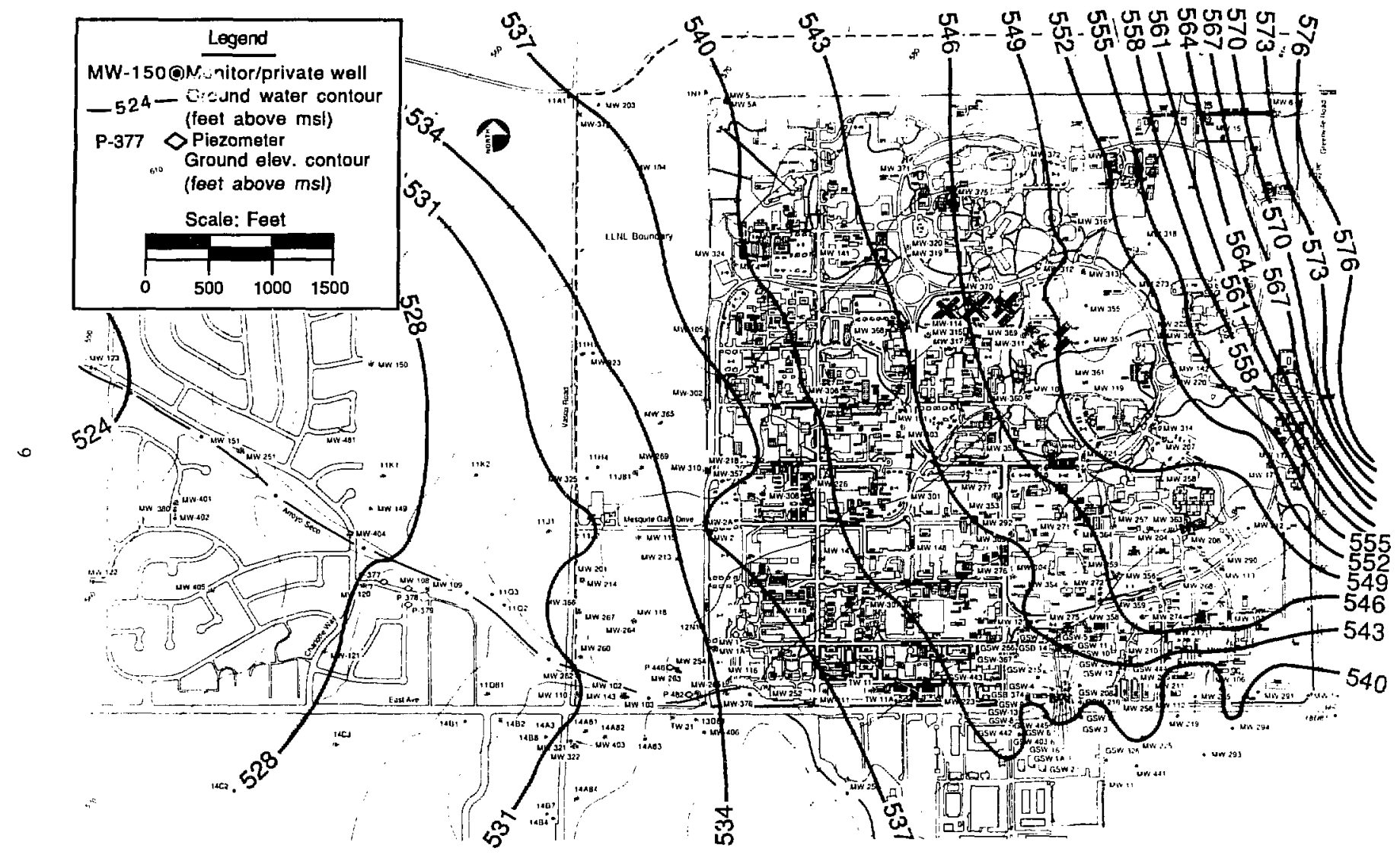

Figure 3. Approximate groundwater surface elevations (f́et above mean sea level), Livermore site and vicinity. 
$30.3 \mathrm{~km}^{2}\left(10.2\right.$ miles $\left.{ }^{2}\right)$. The topography of the site is irregular, with a series of steep hills and ridges onented along a generally northwest/southeast trend: these hills and ridges are separated by intervening ravines. The elevation ranges from approximately $150 \mathrm{~m}(506 \mathrm{ft})$ at the southeast corner of the site to approximately $538 \mathrm{~m}(1750 \mathrm{ft})$ in the northwestern portion. The climate is generally similar to that at the Livermore site, but is modified by the higher elevation and greater relief. The temperature range is somewhat more extreme, and surface wind patterns are influenced by local topography.

Rainfall for the last three months of 1986 totaled $16.9 \mathrm{~mm}$ (0.69 in.). Rainfall for 1987 was $224 \mathrm{~mm}$ (9.15 in.). For the $15-y$ period from 1973 through 1987, the average rainfall was $266 \mathrm{~mm}$ (10.87 in.), with a maximum of $518 \mathrm{~mm}$ (21.16 in.) and a minimum of $145 \mathrm{~mm}$ (5.93 in.).

Knowledge of the geology and hydrugeology of Site 300 is based on regional geologic mapping by Dibblee (1980) and Raymond (1969) and has been supplemented by detailed hydıogeologic studies of portions of Site 30ti in recent years (Raber and Carpenter, 1983; Carpenter et al., 1983; Buddemeier, 1985; and Carpenter et al., 1986).

The bedrock underlying most of Site 300 consists chiefly of sedimentary rock of the late Tertiary Neroly Formation, which is composed of interbedded sandstones, siltstones, claystones, and conglomerates. This formation is underiain by sandstones and claystones of the older Cierbo and Panoche Formations that outcrop in some places. The bedrock is overlain locally by older alluvial and terrace deposits, and more generally by Quaternary colluvial and valley fill deposits.

Groundwater within Site 300 largely occurs within sandstone and conglomerate beds of the Neroly Formation and probably moves through both pores and fractures. Fractures in claystone beds locally convey water (Raber and Carpenter, 1983; Carpenter et al., 1983; and Buddemeier, 1985). Preliminary aquifer tests on interbedded sand-, silt-, and claystones in the northwest portion of the site vielded hydraulic conductivity values ranging from $5 \times 10^{-6}$ to $3 \times 10^{-3} \mathrm{~cm} / \mathrm{s}$ (Buddemeier et al., 1987). Groundwater flow is strongly influenced by geologic structures, tending to follow the dip of the Neroly aquifers. Folds and faults within the bedrock sequence appear to locally influence groundwater gradients and movement (Raber and Carpenter, 1983). In the southern part of Site 300 . groundwater is present in alluvial deposits beneath Corral Hollow (Carpenter et al., 1983).
Drinking and process waler supplies for Site 300 are drawn from production wells located in the southeastern cormer of the site adjacent to Corral Hollow: The water supplies are obtained from deep confined alyuifers; shallow water-bearing zones are not used for supply purposes.

Figure 4 presents a generalized groundwater map based upon data from the significant waterbearing zones present beneatio those portions of Site 300 for which data are avalable. The map also includes the locations of fault systems that appear to have hydrologic significance. Localized perched water-bearing zones have been identified adjacent to the 834 complex in the southeastern portirn of Site 300 and in the vicinity of Bldg. 815 in the south-central portion of the site. The spring south of the HE Process Area wastewater impoundment is a groundwater outcrop of the Bldg. 815 perched water-bearing zone. Other perched springs and isolated groundwater bodies may exist.

The water level map shown in Fig. 4 is based upon elevations measured in several geohydrologic units that do not strictly correlate with one another, although they appear to be in communication at some locations. In the northwestern portion of Site 300 , water surface elevations shown are for a shallow perched water-table aquifer (Raher and Carpenter, 1983; Carpenter et al., 1983; Carpenter, 1983; Buddemeier, 1985; and Carpenter et al., 1986). In portions of this area, boreholes drilled to a depth of nearly $92 \mathrm{~m}$ (300 ft) heneath the perched aquifer have failed to encounter any deeper water-yielding zones (Raher and Carpenter, 1983). Northeast of the Elk Ravine Fault, data depicted is for a semi-confined aquifer that is the uppermost of a sequence of aquifers with differing heads and geochemical properties (Raber and Carpenter, 1983). Beneath the southeastern portion of Site 300 , both a water-table aquifer and a deeper confined aquifer are present. Contours shown are based upon data points obtained from the water-table aquifer.

Sewage from the administrative area in the southeast corner of Site 300 is discharged to a lined pond for digestion and evaporation. Other facilities at Site 300 are served by septic tanks.

The Carnegie State Vehicular Recreation Area is located south of the western portion of Site 300 . Adjacent to Site 300 to the east is an HE test facility operated by $\Gamma$ hysics International; a similar facility operated by SRI International is located approximately $1 \mathrm{~km}(0.6 \mathrm{miles})$ south of Site 300 . An increasing number of power-generating windmills 
are being installed northwest of the site. The re mainder of the land around Site 300 is in agricultural use, primarily as grazing land for cattle and sheep. The nearest residential area is the City of Tracy (population 25000 ). located $10 \mathrm{~km}$ (6 miles) to the northeast.

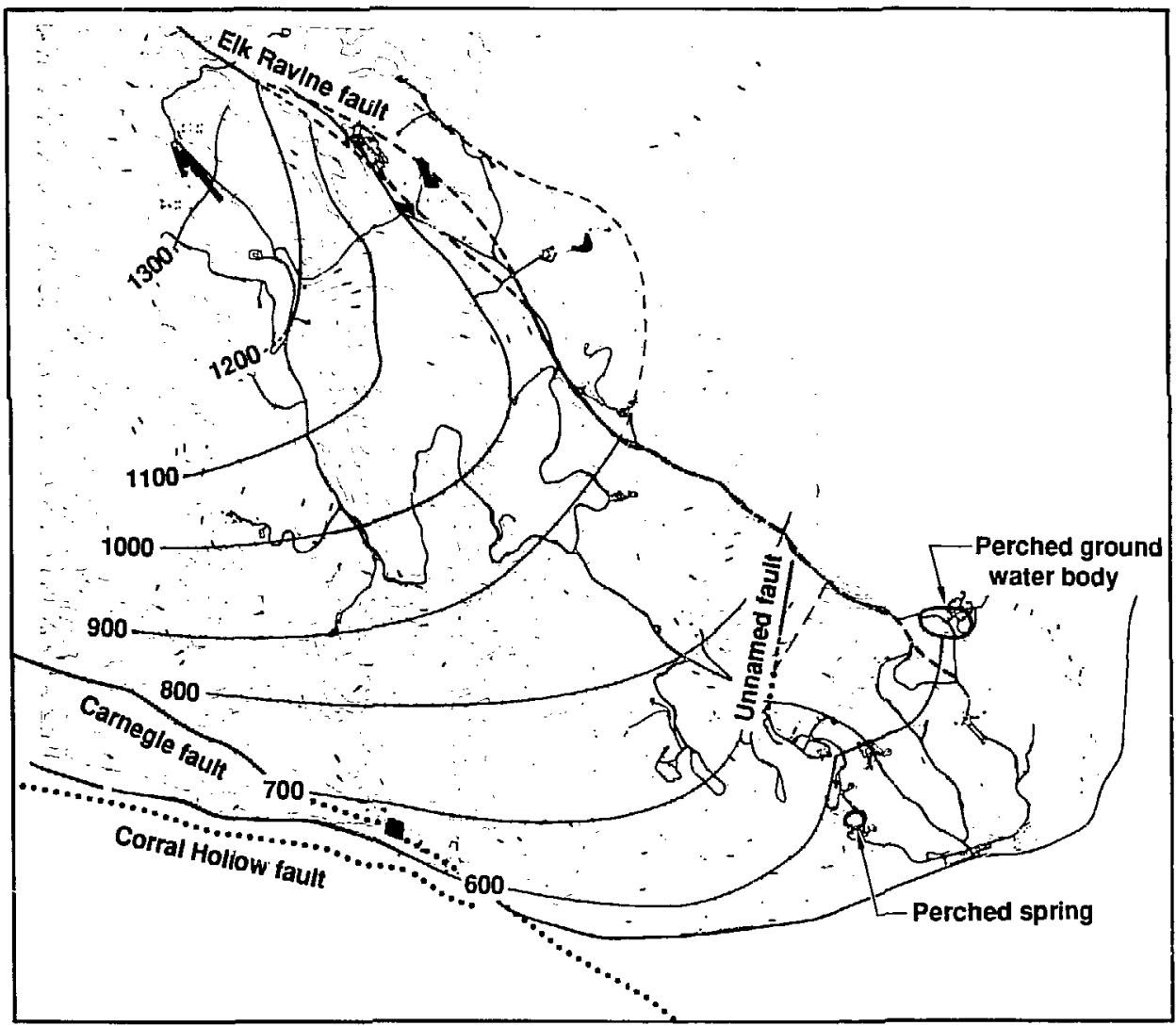

\section{Legend}

Fault:

Dashed where inferred; dotted where concealed; querled where existence doubtful

-800- Groundwater surface elevation contour

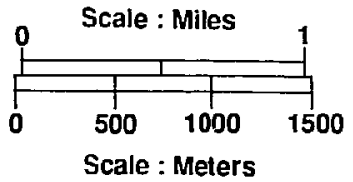

Figure 4. Topography and groundwater surface elevations, Site 300. 


\section{Environmental Monitoring-Methods and Results}

\section{Methods}

Environmental monitoring samples are analyzed by LLNL or commercial laboratories. When applicable, Environmental Protection Agency (EPA) standard methouss are used to collect and analyze the samples. If EPA standard methods are not available. LLNL develops its own procedures. Appendix $D$ is a synopsis of those procedures.

\section{Air Monitoring}

Concentrations of various airhorne radionuclides and beryllium are measured at the Livermore site perimeter, at off-site locations near the Livermore site, and at Site 300 . Sampling locations are shown in Figs. 5 through 7 . The six samplers on the Livermore site perimeter (Fig. 5), the eight samplers at Site 300 (Fig. 6), and seven of the offsite Livermore Valley samplers (Fig. 7) use

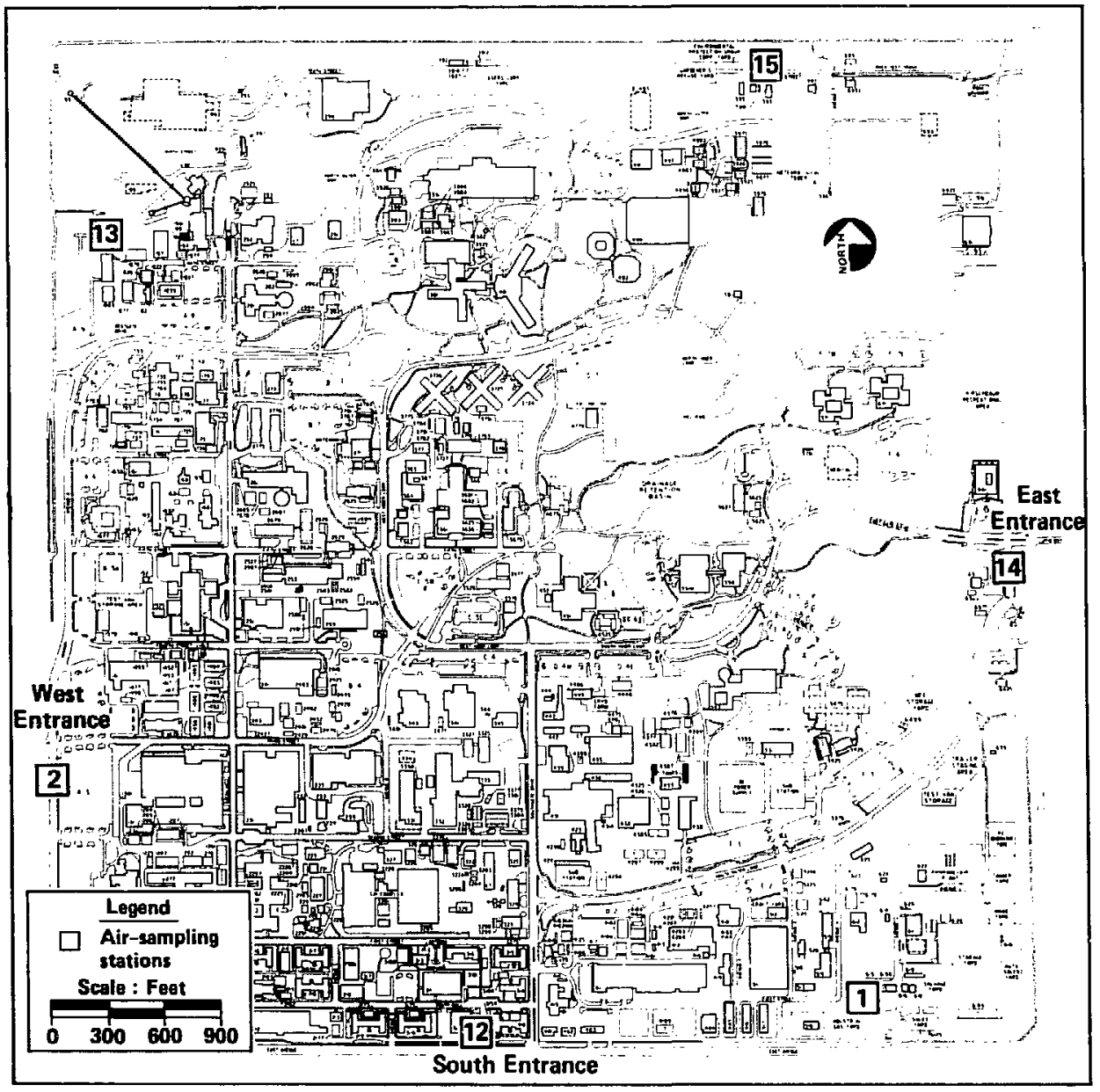

Figure 5. Air-sampling locations, Livermore site perimeter. 
$5.2 \times 10^{-} \mathrm{m}^{2}$ Whatman +1 cellulose filters. These samplers are operated at average flow rates of 400 to $1000 \mathrm{~L} . / \mathrm{min}$. The filters are cut in half; one half of each filter is retained for beryllium analysis (as a monthly composite). An easily dissolvable filter and a low trace-metal background are required for these analyses. Whatman 41 represents a balance between such requirements and particulate-collection efficiency (Lindeken et al., 1963). The remaining offsite samplers (Fig. 7) use $8.11 \times 10^{-3} \mathrm{~m}^{2}$ glass-fiber filters (Flanders F-700) and are operated at a flow rate of $85 \mathrm{~L} / \mathrm{min}$. All air filters are changed weekly.

After a four-day delay for decay of the radon-thoron daughters, gross alpha and beta activities on the filters are determined with an automatic gas-flow proportional counter. Monthly composites of Livermore site perimeter and Site 300 filters are also counted for gamma-emitting radionuclides using low-background $\mathrm{Ge}(\mathrm{L} i)$ detec- tors. Following gamma counting, the site perime ter filters from individual locations and the site 300 composites are analyzad for the presence of ${ }^{27 *} \mathrm{Pu},{ }^{2 i n} \mathrm{U}$. and ${ }^{2 k \mathrm{U}} \mathrm{U}$. Selected off-site samples from the Livermore Valley and the City of Tracy are analyzed for ${ }^{234} \mathrm{Pu}$.

Concentrations of airborne tritium are determined for each of the Livermore site perimeter air-sanpling locations, off-site locations 51 and S2, and four additional Livermore Valley locations. Water vapor is collected on silica-gel samplers operated at a flow rate of about $0.7 \mathrm{~L} / \mathrm{min}$ for a two-week period. The collected water is recovered by freeze-drying. and the tritiated water is measured by liquid-scintillation counting.

\section{Soil Monitoring}

An intensive soil-sampling program conducted in 1971 and 1972 provided a data base for the concentration ranges of various radionuclides

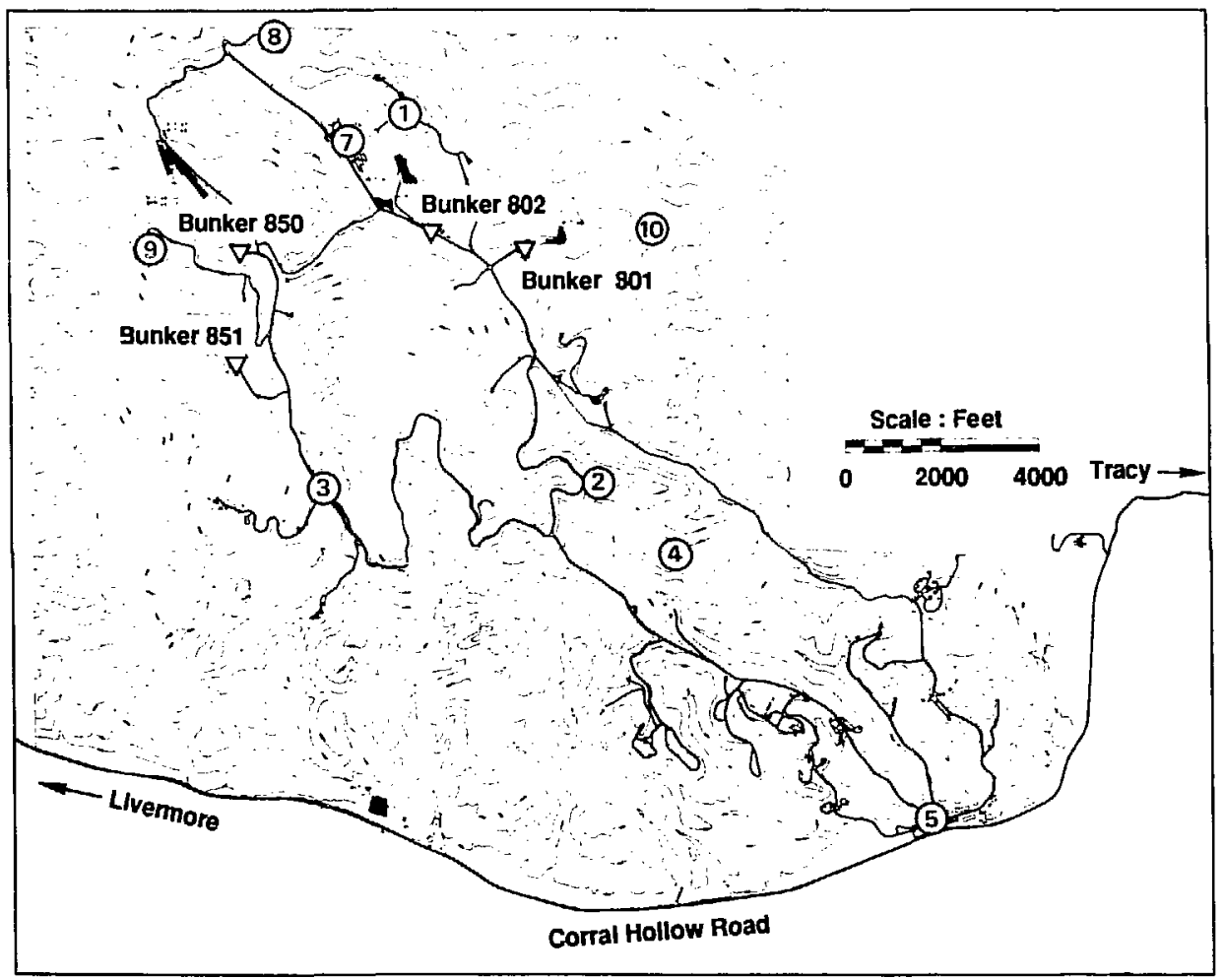

Figure 6. Air-ampling locations, Site $\mathbf{3 0 0}$. 


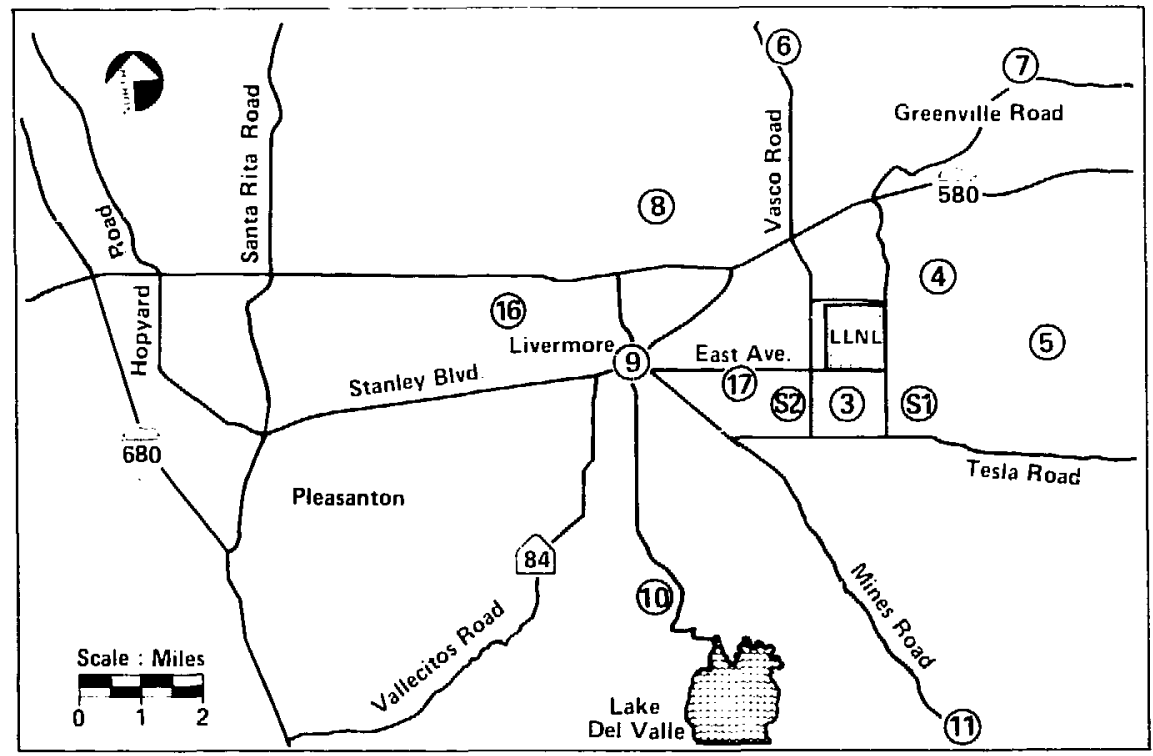

Figure 7. Air-sampling locations, Livermore Valley.

in soil near the Livermore site and at Site 300. Since 1972, soil sampling in the vicinity of the Livermore site and at Site 300 has been part of a continuing LLNI_ monitoring program to document any changes in environmental levels of radioactivity that have occurred and to evaluate any increase in radioactivity that might have resulted from LLNL operations. As in previous years, a group of soil samples was collected at sites selected at random from the list of Livermore Valley locations sampled in the 1971-1972 study. Figure 8 shows the 1987 soil-sampling locations in the Livermore Valley, and Fig. 9 indicates the locations at Site 300 . Eleven of the Site 300 soil samples were collected from locations that have been sampled annually since 1973. In 1986, two additional sample locations were added in drainage channels where surface runoff might be expected to concentrate suspendable particulate material.

All samples are collected to a depth of $5 \mathrm{~cm}$. After collection, the samples are dried, ground, and blended. Plutonium-239 content is determined in each sample following an acid-leaching procedure. For gamma-spectra analysis, approximately $300-\mathrm{g}$ aliquots of the soils are sealed in $200-\mathrm{cm}^{3}$ thin-walled cans of aluminum and counted with a $\mathrm{Ge}(\mathrm{Li})$ detector.

\section{Sewage Monitoring}

The Livermore site discharges approximately 400000 gal per day of wastewater to the City of Livermore sewer system. This wastewater contains sanitary sewage and industrial effluent from both LLNL and SNLL. The wastewater is controlled to minimize contamination. A small amount of the effluents from LLNL buildings exceeds permissible pollutant levels and is treated to reduce pollutants to the lowest levels practical and below applicable standards. Radioactive materials in the waste are reduced to levels well below DOE and LWRP discharge limits (U.S. Department of Energy, 1987a). An on-line monitoring system and flow proportional sampler are located at the outfall from the Livermore site. The effluent is continuously monitored for $\mathrm{pH}$, selected metals, and radioactivity. If warning levels are exceeded, an alarm is registered at the LLNL Fire Dispatchers Station, which is manned $24 \mathrm{~h}$ a day. A sanitary sewer spill plan and a trained response team have been established to minimize effects of a spill should one occur. The monitoring system provides a continuous check on waste control. It also provides an alert mechanism that is triggered if waste is discharged above set limits. 


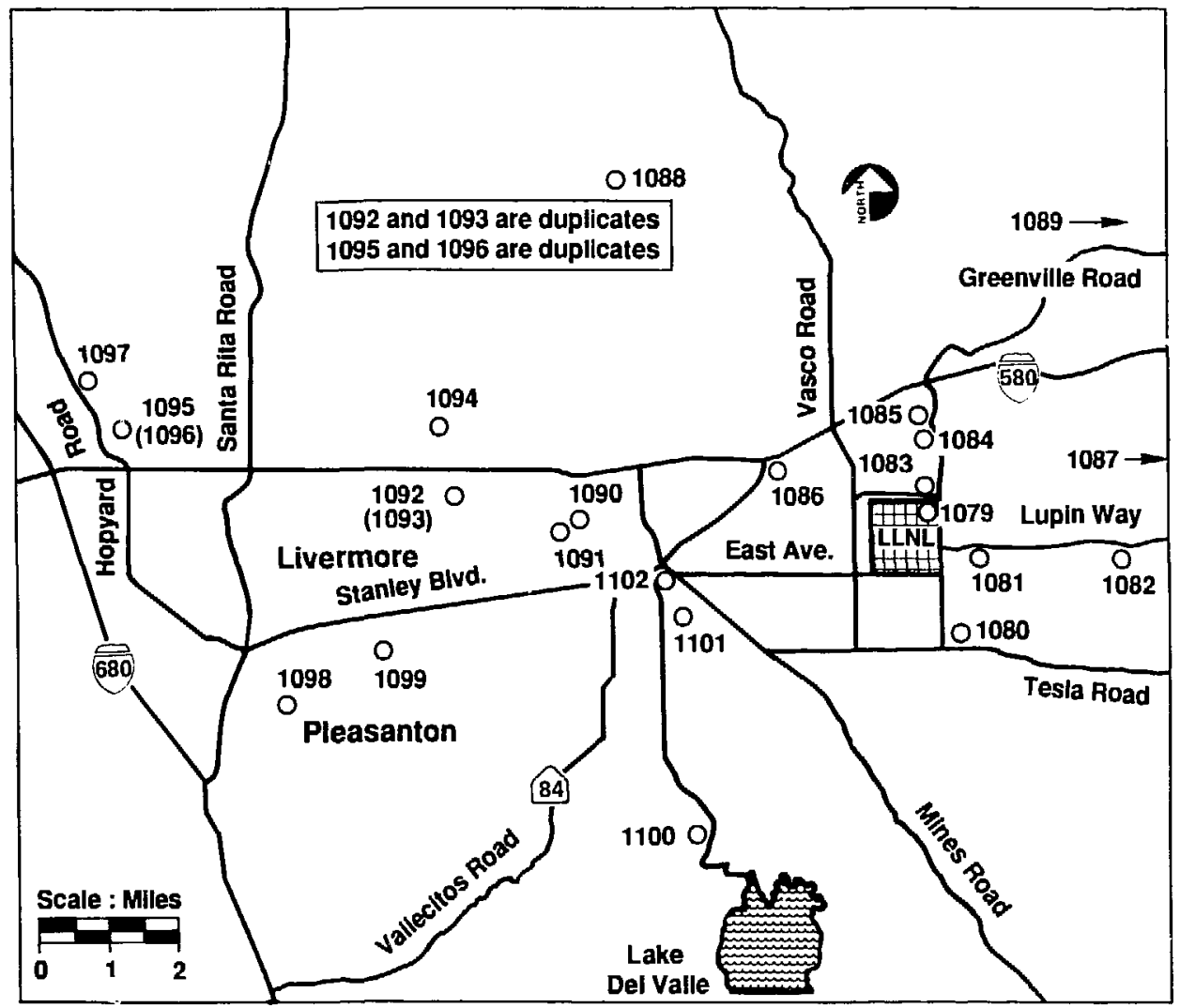

Figure 8. Soil-sampling locations, Livermore Valley.

LLNL is in the process of upgrading the existing liquid effluent outflow monitoring system to allow more accurate assessment of many of the parameters of concern. In addition, LLNL is evaluating a system of satellite monitoring stations and a diversion structure to operate in conjunction with the sewer monitoring system. The diversion system would help to ensure that wastewater triggering an alarm is retained at LLNL for evaluation and disposal. The satellite monitoring stations would be positioned in the outflow lines of those buildings with historical records of accidental releases. They would not monitor the full range of parameters, but only those pertaining to the building or facility being monitored.

A representative fraction of the total waste stream is collected by a flow proportional sampler and composited over a $24-h$ period. These samples along with grab samples from the LWRP effluent are collected daily. The daily composite samples are analyzed for gross alpha, gross beta, and tritium activity. Samples of the Livermore site and LWRP effluent are also each combined to form a monthly composite for ${ }^{137} \mathrm{Cs}$, ${ }^{239} \mathrm{Pu}$, and heavy metal analyses. The LWRP digesters are sampled monthly and analyzed for gross radioactivity and heavy metals; they are also sampled quarterly for plutonium analysis. In addition, samples of the LLNL sewage effluent are collected quarterly and analyzed for parameters specified on LWRP's National Pollutant Discharge Elimination System permit. Discharge limits imposed by the City of Livermore are shown in Appendix E. 


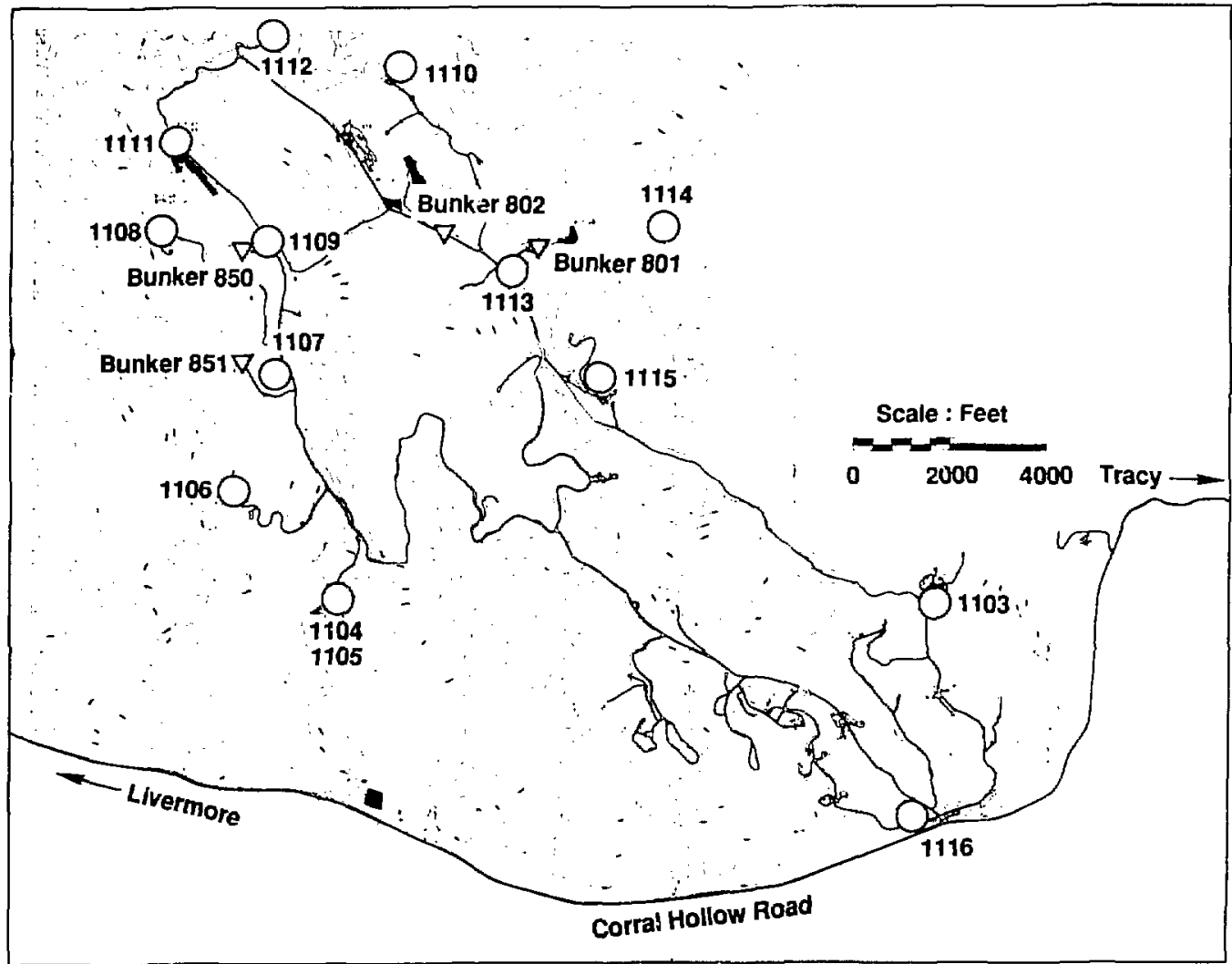

Figure 9. Soil-sampling locations, Site 300. 


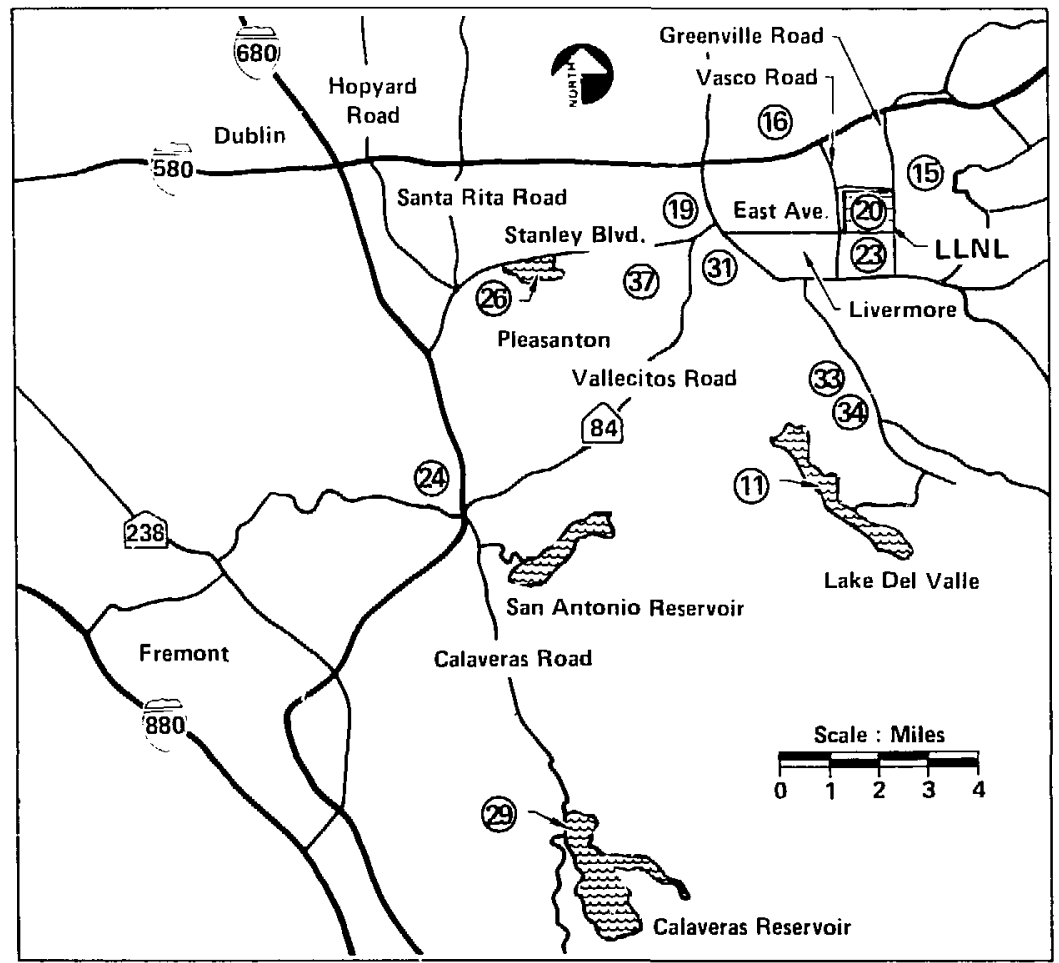

Figure 10. Water-sampling locations, Livermore Valley.

Since February 1980, the LWRP has been connected to a pipeline constructed as part of the Liveimore-Amador Valley Wastewater Management Program to transport wastewater out of the valley for discharge into the San Francisco Bay. Although some treated LWRP effluent is still used to irrigate municipal property during summer months, sewage is no longer discharged into Arroyo Seco. This has eliminated the primary means of tritium migration to local and downstream ground water from the LWRP.

\section{Routine Water Monitoring}

This subsection describes the ongoing monitoring program for surface ana domestic water in the vicinity of the Livermore site and at Site 300 . Expanded water-quality monitoring efforts are described in the "Compliance Groundwater Monitoring" subsections; special investigations relating to groundwater quality are presented in the "Special Monitoring Assessments" section.
Livermore Valley water-sampling locations are shown in Fig. 10. Locations 11, 15, 16, 23, 24, 26 , and 29 are surface water sources (ponds, creeks, aqueducts, or reservoirs). Location 20 is the rainfall collection site for the Livermore site. The other six locations are domestic water supply wells. Site 300 water samples (Fig. 11) were collected from on-site wells (locations 1 through 6 and 22, 24), off-site wells (location 23), and two off-site creeks (locations 7 and 14). Location 20 is the Site 300 rain gauge, and location 21 is a spring-fed pond near Bunker 812 . The water samples from both the Livermore Valley and Site 300 are analyzed for gross alpha, gross beta, and tritium activity. Because of the low tritium levels typically found, it is necessary to distill and enrich the samples before liquid-scintillation counting.

As noted previously, a small fraction of treated effluent from the LWRP is used to irrigate nearby municipal property. This effluent contains low levels of tritium that come from normal LLNL 


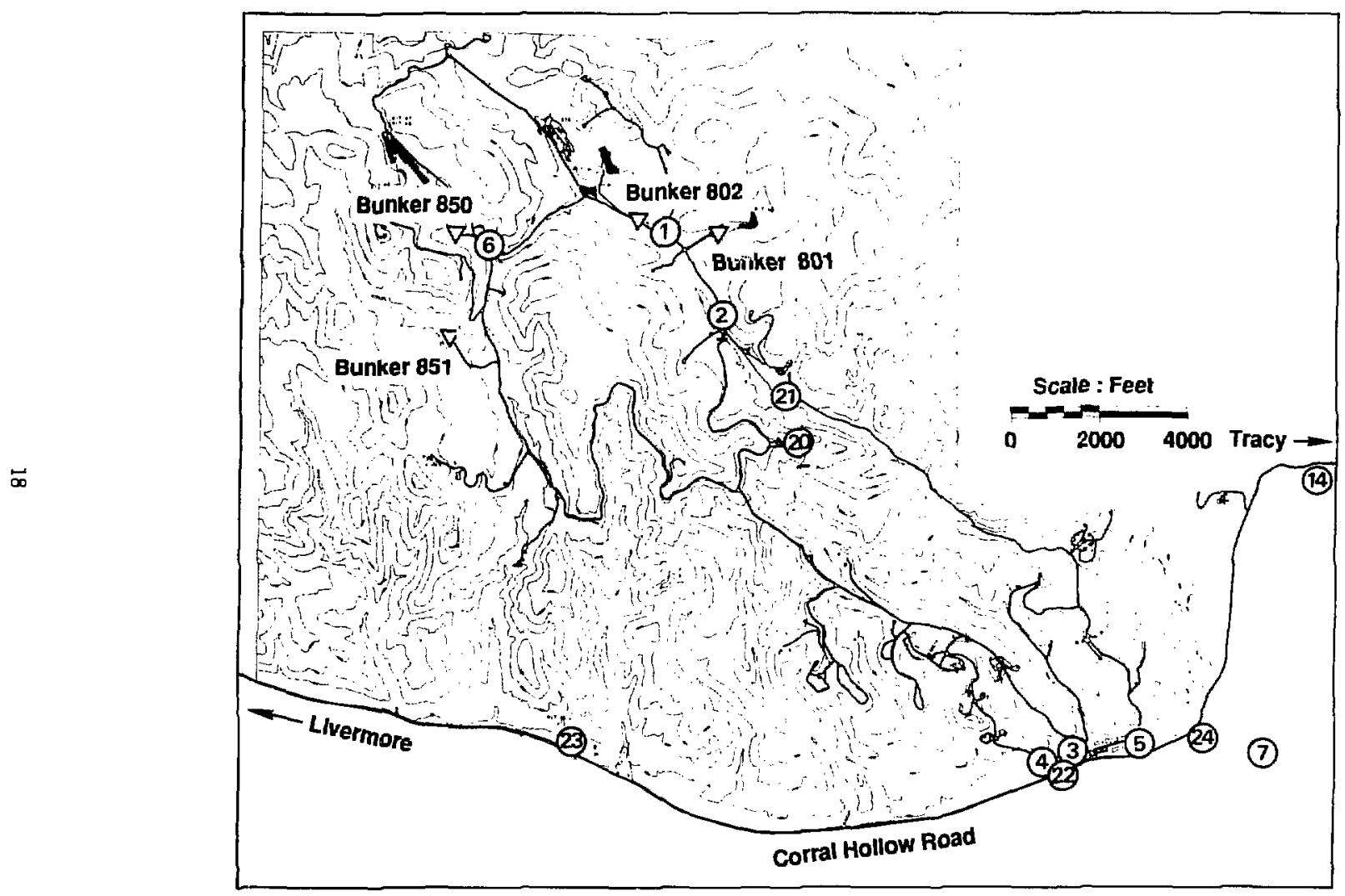

Figure 11. Water-sampling locations, Site 300. 


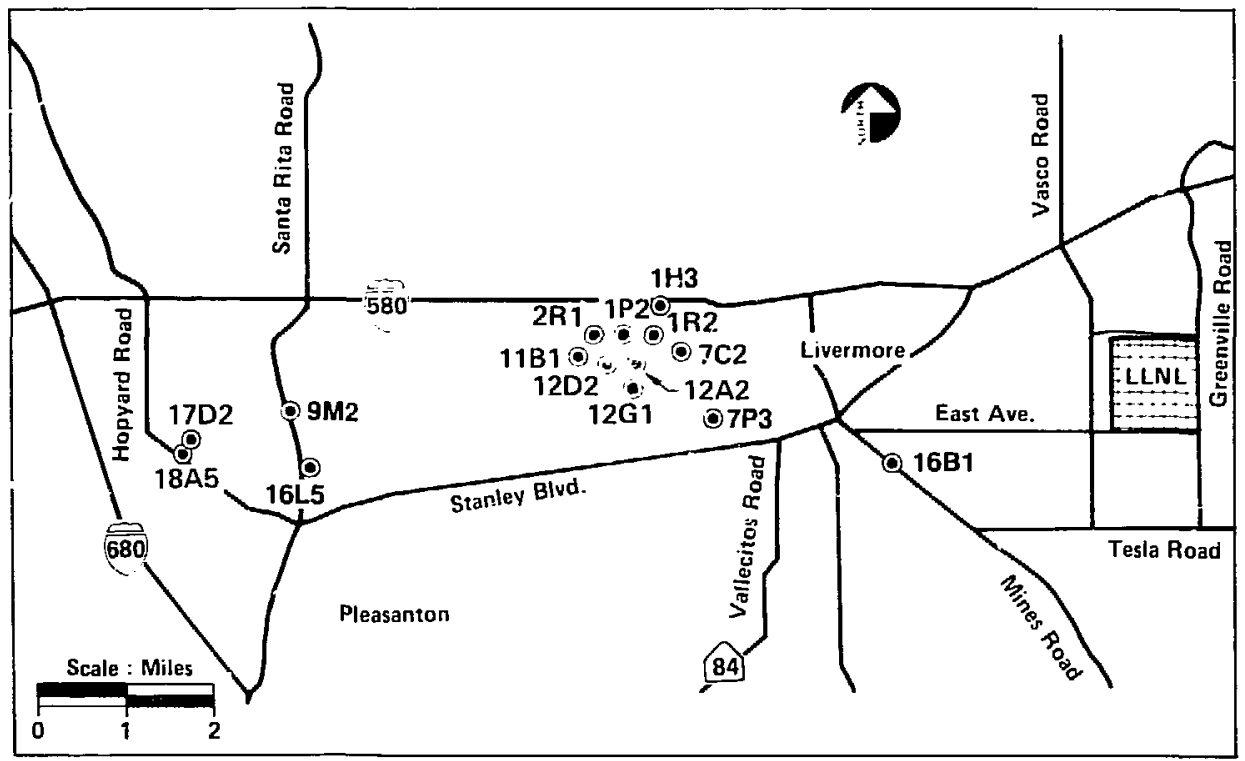

Fig.tz 12. Groundwater-sampling locations, Livermore Valley.

and SNLL operational releases to the sanitary sewer system. As part of a study begun in 1977. triijum measurements are now made annually on well-water samples collected from neighboring wells to determine the extent of tritium migration into the groundwater. Many of the wells are in the immediate vicinity of the LWRP; however, additional samples were also collected from areas at some distance away. Locations sampled during 1987 are show' n in Fig. 12.

Beginning in 1975, L.LNL's Environmental Monitoring Program was expanded to include surface runoff monitoring. The program was originally designed to detect the pesticides used at LLNL, which include herbicides, fungicides, and insecticides, in samples collected from the drainage ditch at the northwest corner of the Laboratory following the first major storm. Additional sampling points were subsequently added and samples analyzed for metals, radioactivity, general water-quality parameters, and other priority pollutants, in addition to pesticides.

As presently designed, the runoff monitoring program calls for the sampling of six locations (Fig. 13) during the period of active surface water flow following the first major storm of the rain season. Station 1 is the influent to the east side of the Livermore site that feeds the Arroyo Las Positas flow; station 2 is from the on-site "lake"; and station 3 is the effluent into the redirected $\mathrm{Ar}$ royo Las Positas channel at the northwest site boundary. Station 4 is in the Arroyo Seco channel influent to the SNLL. site; station $\mathbf{5}$ is the effluent to the Arroyo Seco channel of a culvert that collects surface drainage from the southeast area of the Livermore site; and station 6 is the Arroyo Seco channel effluent at the western boundary of the Livermore site buffer zone (Vasco Road). No storms created sufficient runoff for sampling during the spring of 1987 . Therefore, only data for runoff during the fall of 1987 are presented.

Water samples from 22 locations surrnunding Site 300 were collected during the spring and summer of 1987 and analyzed for the DOHS drinking water parameters (State of California, 1977). This analysis was designed to characterize the general water quality (both surface and groundwater) of the area around Site 300 .

\section{Vegetation and Foodstuff Monitoring}

Vegetation samples are collected quarterly at locations in the Livermore Valley (Fig. 14) and at 


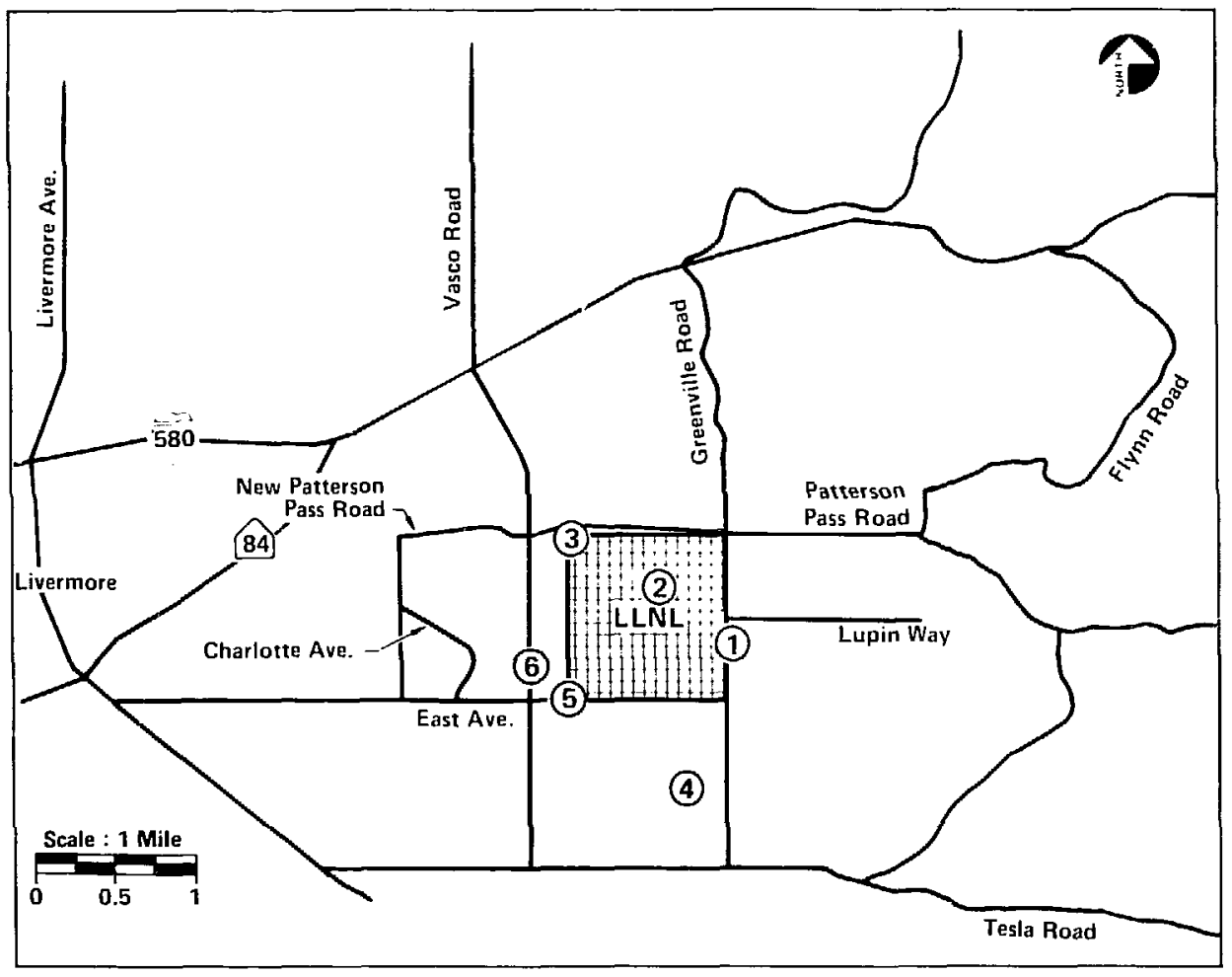

Figure 13. Stormwater-runoff sampling locations.

Site 300 (Fig. 15). These samples are freeze-dried and the tritium activity in the recovered water is determined by liquid-scintillation counting.

Wine samples obtained in 1987 were analyzed for tritium. The wine samples were vacuumdistilled and analyzed by liquid-scintillation counting. Because of a laboratory instrument malfunction, the wines could not be analyzed with the usual procedure, which consists of oxidizing the wine to water and carbon dioxide, then measuring the water by gas proportional counting.

Samples of honey produced from a variety of flower sources both inside and outside the Livermore Valley were also analyzed for tritium content. Following oxidation of the samples in a Parr oxygen bomb, the content of the water produced was determined by gas proportional counting.

\section{Milk Monitoring}

During 1987, goat-milk samples were obtained from five farms within about $5 \mathrm{~km}$ of the
Livermore site. Three of these farms produced milk only during the spring, and are no longer producing milk. A portion of each sample was freeze-dried and the water analyzed for tritium activity by liquid-scintillation counting. Another portion was preserved with formalin, and a $1-\mathrm{L}$ aliquot was gamma counted in a Marinelli beaker on a $\mathrm{Ge}(\mathrm{Li})$ system.

\section{Environmental Radiation Monitoring}

External dose rates from penetrating radiation (primarily gamma rays) are measured at 22 Livermore site perimeter locations (Fig. 16) and 55 off-site locations (Fig. 17). These measurements are made with thermoluminescent dosimeters (TLDs) using previously published procedures (Lindeken et al., 1975). The TLDs contain two types of phosphors: $\mathrm{CaF}_{2}: \mathrm{Dy}_{\text {y }}$ (Harshaw TLD-200) and LiF (Harshaw TLD-700). The TLD chips are housed in a plastic holder $350 \mathrm{~mm}$ in diameter and $3 \mathrm{~mm}$ thick, and are held in place by a thin 


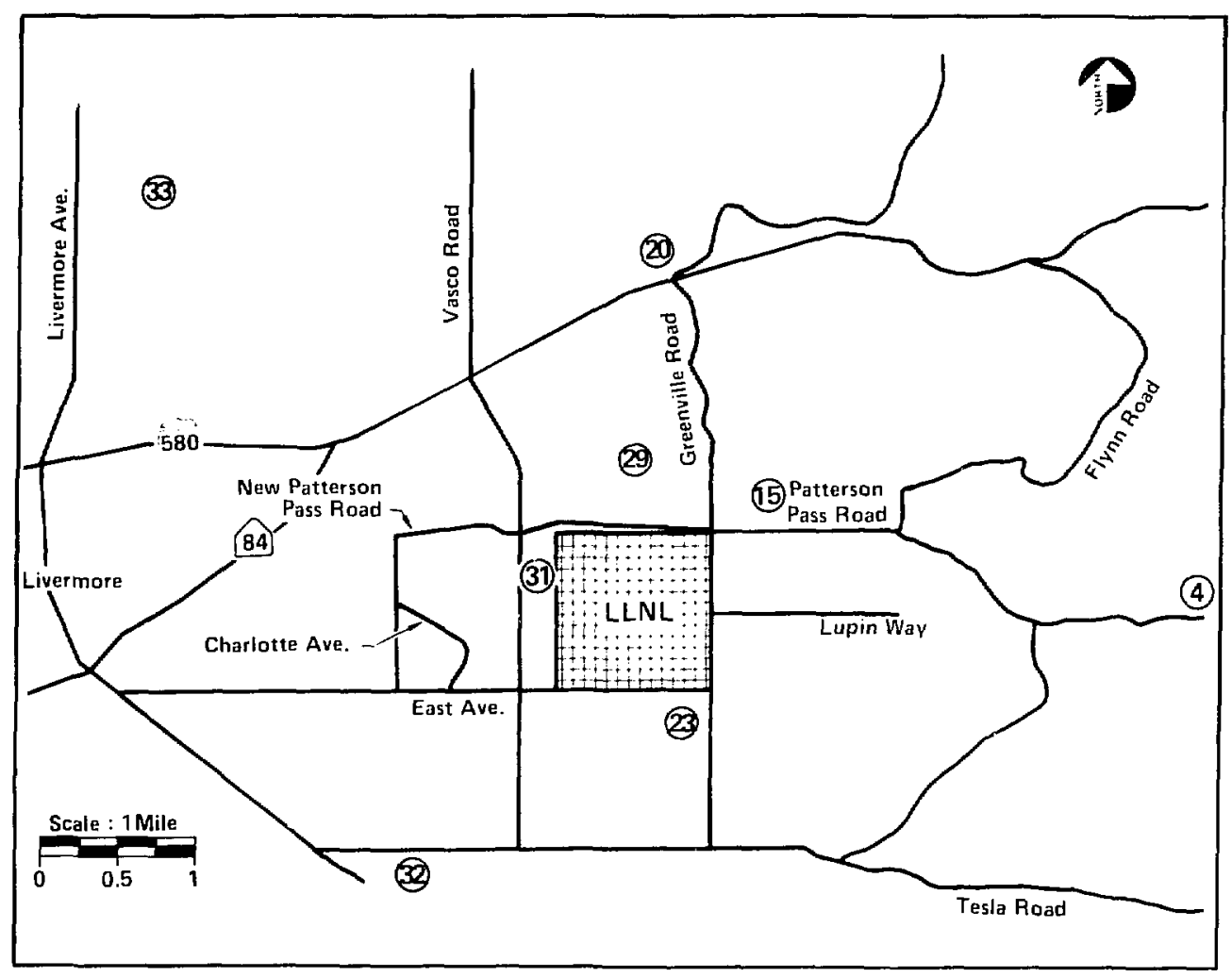

Figure 14. Vegetation-sampling locations, Livermore Valley. 


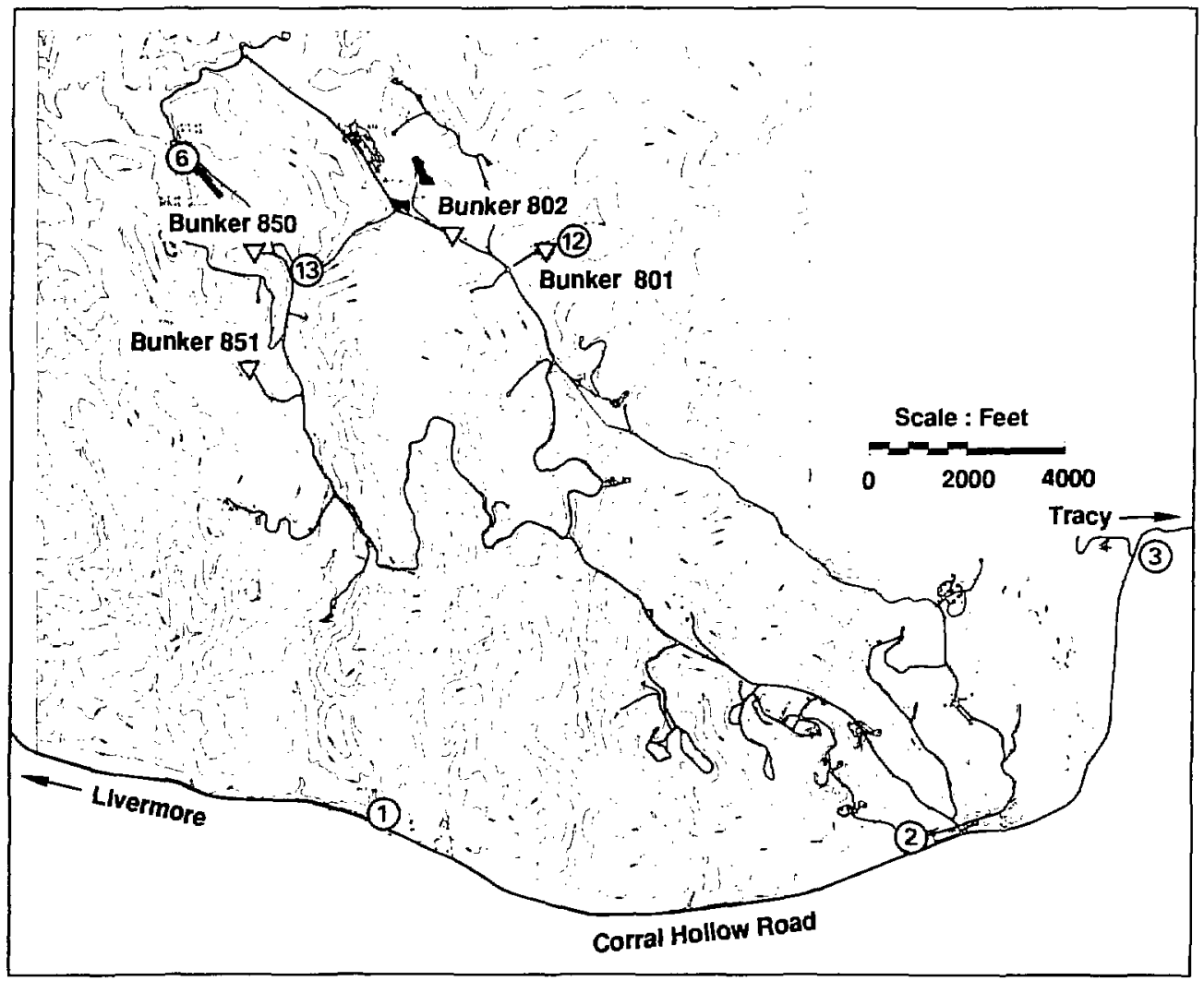

Figure 15. Vegetation-sampling locations, Site 300. 


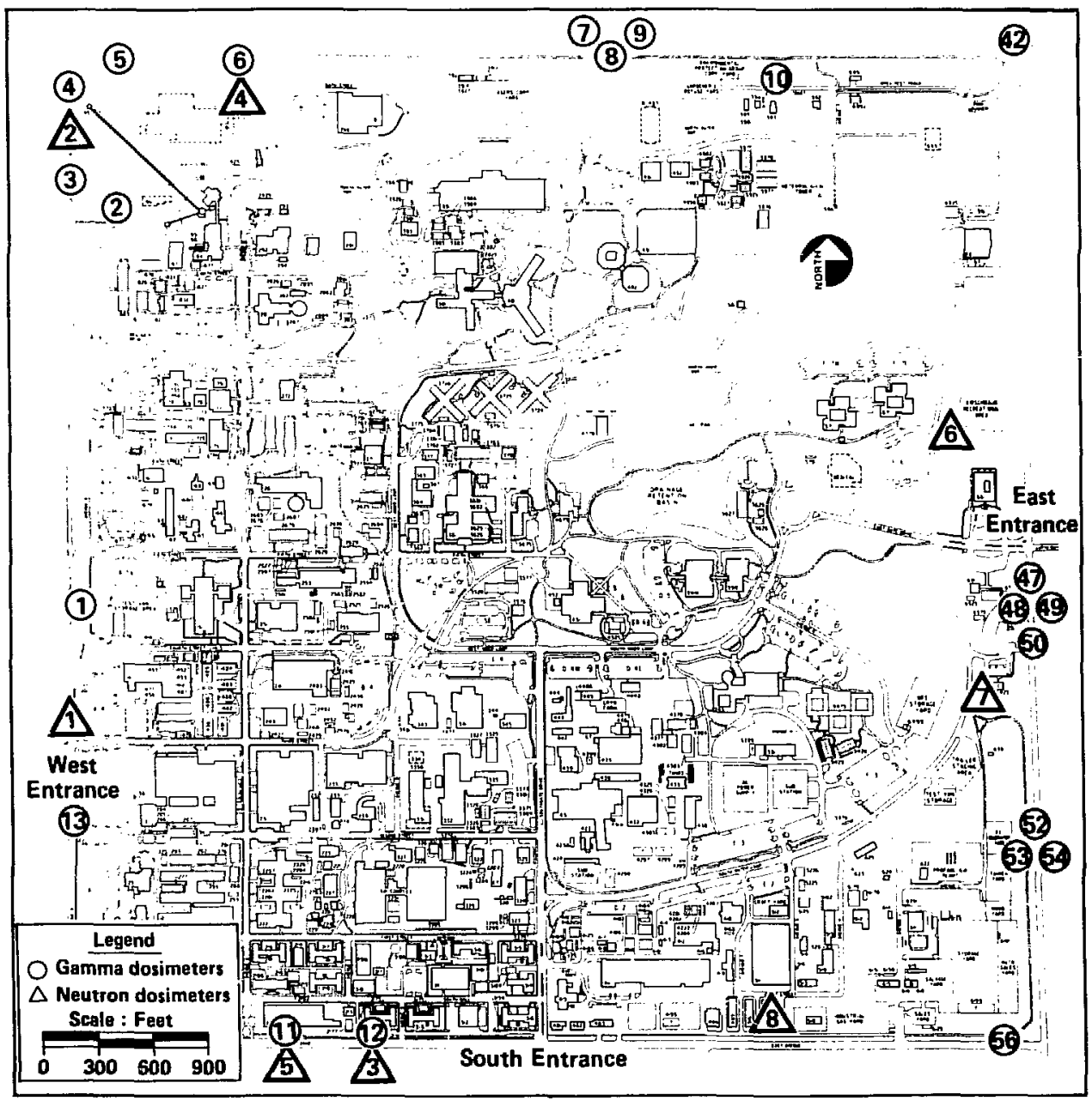

Figure 1b. Locations of gamma and neutron dosimeters, Livermore site perimeter. 


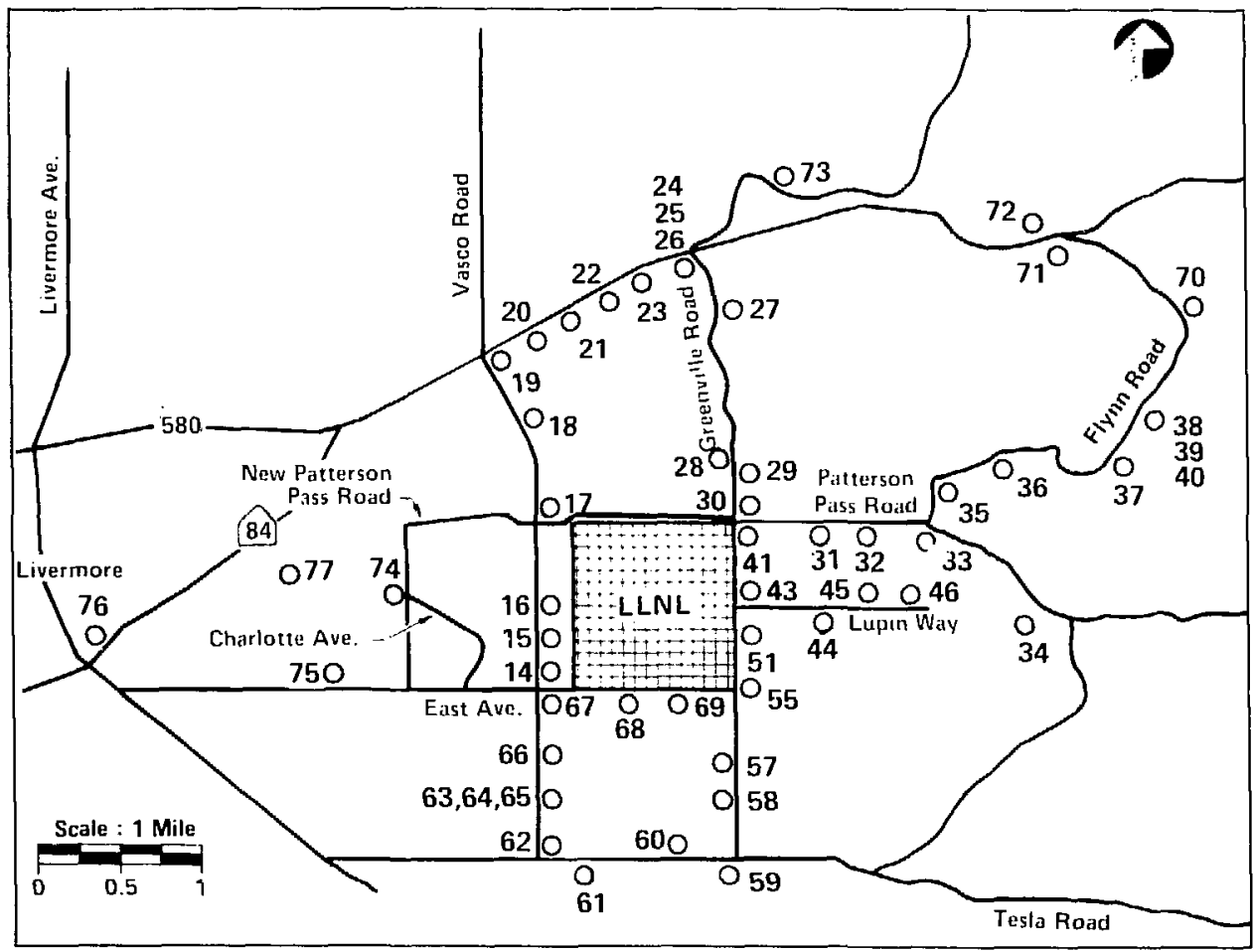

Figure 17. Locations of gamma dosimeters, off site.

plastic cover. The dosimeters are mounted in the field on existing structures (such as fence lines) at approximately $1 \mathrm{~m}$ above ground level. The dosimeters are exchanged quarterly.

The TLDs measure environmental radiation exposure rates in milliroentgens $(m R)$. The exposure rates are converted to dose equivalent units (mrem) to compare with existing dose standards. Throughout this report, the conversion factor relating $\mathrm{mR}$ to mrem in a beta/gamma radiation field is assumed to be 1.0 .

The TLDs measure radiation exposure from all sources of penetrating radiation. These include natural sources, fallout from nuclear weapons testing, as well as any contribution from LLNL. Off-site dosimeters are located in areas where access to the general public is not restricted. These areas are considered background and are used for comparison with the perimeter dosimeters.
LLNL is in the process of changing the TLDs from the Harshaw's to a Panasonic UD 814 that employs thulium-activated calcium sulfate phosphor.

Environmental neutron dose rate measurements using ${ }^{2} \mathrm{U}$ track-etch detectors are also mate at eight locations on the livermore site perimeter. A detailed description of the detector and the spark-counting procedure used may be found in Fisher, 1976. Neutron-monitoring locations are shown in Fig. 16.

\section{Noise Monitoring}

As noted earlier, LLNL's HE open-air diagnostic work is conducted at Site 300 . Because the site is remote, these experiments can be performed with minimal off-site impact from annoying noises or damaging overpressures. On the basis uf meteorological measurements made at least twice each dav, a limit is set on the weight of HE 
that can be detonated without impact in populated areas. To monitor this limit, five microbarograph sensors are maintained in or near the City of Tracy because Tracy in in the direction of the prevailing winds.

\section{Compliance Groundwater Monitoring}

Groundwater monitoring is conducted under two programs at LLNL. One program is designed is meet regulatory commiments established for specific site investigations, such as the Livermore Ground Wiater Project and the Site 300 Trichloroethylene (TCE) Investigation. These efforts and others are described in the "Special Monitoring Assessments" section of this report. The other program inclutes groundwater quality monitoring for drinking water parameters as well as routine compliance monitoring around landfill and wastewater surface impoundment units, as required by the California Regional Water Quality Control Board (CRIVQCB), Central Valley Region, and the EPA. The latter program is described below.

In the vicinity of Site 300 landfills, groundwater monitoring is regulated by the CRWQCB, DOHS, and EPA. There are two active landfill monitoring programs. At Pit 1 . groundwater samples from eight monitoring wells are analyzed quarterly for drinking water parameters, groundwater quality parameters, and indicators of groundwater contamination, as specified in Title 40, Part 265.92, of the Code of Federal Regulations (Office of the Federal Register, 1986a). At Pit 7. eight monitoring wells are sampled quarterly for purgeable priority pollutants (pursuant to 40 CFR 265.92), lead, beryllium, gross alpha, gross beta, and tritium. Pit 7 wells also provide monitoring for inactive landfills 3,4 , and 5 .

Groundwater from wells that monitor Pits 2 and 8 is also analyzed as described for $P i t 7$, as well as for nitrate, nitrite, ammonia, and total kjeldahl nitrogen. Wells K2-04, K2-04S, and K204D were sampled during the fourth quarter of 1987; the results of the analysis are incluted in this report. Well NC2-07. located at the site's western boundary, is the most downgradient monitoring point for Pits 2, 3, 4, 7, and 8. This well is analyzed quarterly for tritium and semiannually for gross alpha, gross beta, and purgeable priority pollutants.

Pit 6 is monitored for drinking water parameters, groundwater quality parameters, and indicators of groundwater contamination, as specified in Title 40. Part 265.92, of the Code of Federal Regulations (Office of the Federal Register, 1986a), because records indicate that waste, including capacitors suspected to be contaminaled with polychlori. nated biphenyle ( $\Gamma C^{-} B$ ). heryllium mercurs: misceslaneous chemicals. and other potentially has ardous wasten were buried in this pit betweon 1964 and 1973.

In 1985. the Contral Valley kegion of the CRWQCB issued new groundwater monitoring requirements as part of Wasle Discharge Order No. 85-188 for I.I.NI s wo new Clase II surface impoundments. These impoundments contain treated nonhazardous $\mathrm{HE}$ process wastewater and photo rinse water. Samples from four wells are amalyzed quarterly for $\mathrm{pH}^{\mathrm{H}}$, total organie halides (TOX), total organic carbon (TC, ), specific conductance, several explosives compounds (HMIX, RDX, nitrate, nitrite), purgeable priority pollutants, and metallic elements. Quarterly, an attempt is made to sample the five lysimeters underlying the surface impoundments. If water is present it is analyzed for HE compounds.

As part of the special assessments studies at Site 300, a monitoring network was established in the southeastern area of the site. These wells are sampled on a quarterly or monthly hasis for volatile organit compounds (VOCs) using EPA method 601 . This network is described in more detail in the section titled "Special Monitoring Assessments."

Site 300 has eight standby wells that are, or have been, used for the production of drinking water. Only three are currently being used for production. Quarterly samples from these wells are analyzed for gross alpha, gross beta, tritium, chromium, copper, lead, beryllium, and purgeable priority pollutants. The radiological analyses are considered to be part of the "Routine Water Monitoring" Program and are discussed earlier in the subsection by that name.

As described in the "Special Monitoring Assessments" section, numerous wells were installed as part of the LLNL Groundwater Project. As these new wells were installed. water samples were collected and analyzed for the DOHS primary drinking water standarts (State of California, 1977) and for organic compounds identified by EPA method $624 / 625$. Well locations are shown in Fig. 18.

\section{Results}

\section{Air Monitoring}

Airborne Radioactivity. Figure 19 shows airhorne gross alpha and gross beta activities for the Livermore site perimeter. Figure 20 shows these activities for the Livermore Valley, and fig. 21 


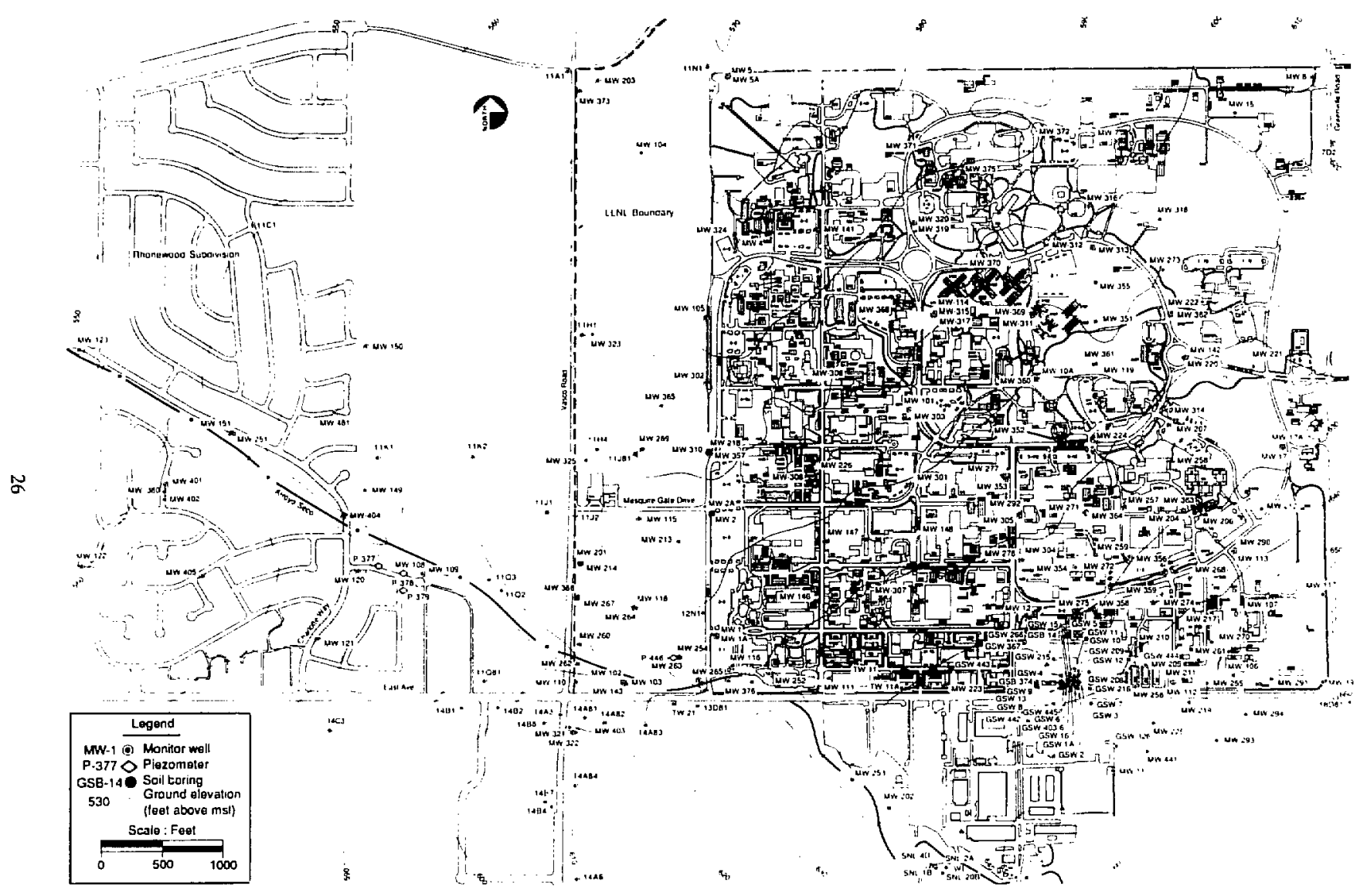

Figure 18. Monitoring wells analyzed for water-quality parameters, off site. 


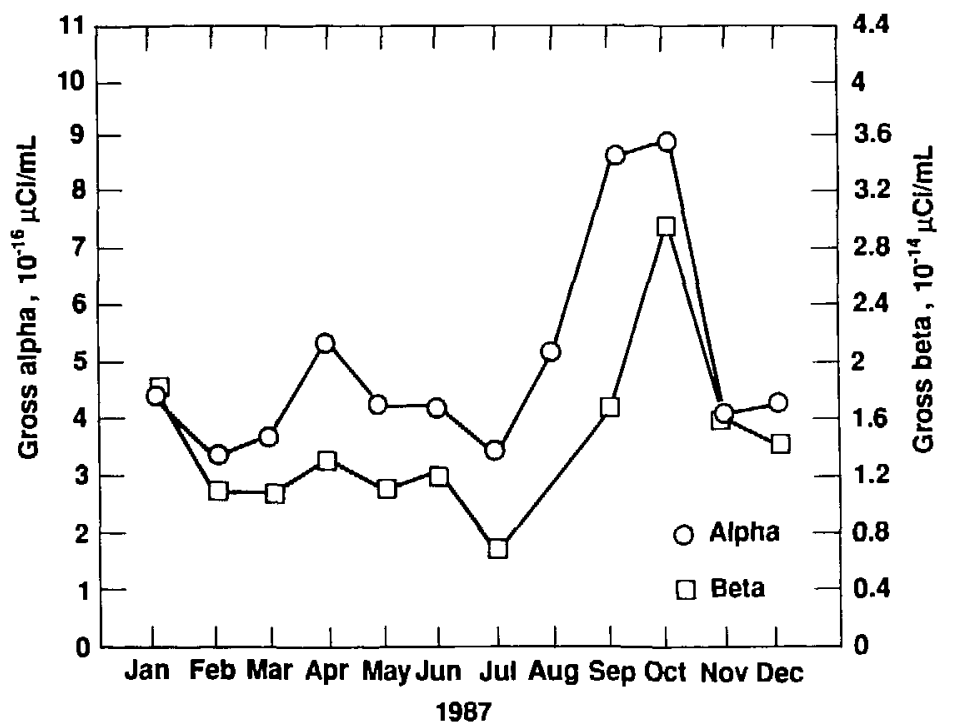

Figure 19. Gross alpha and beta activity on air filters, Livermore site perimeter.

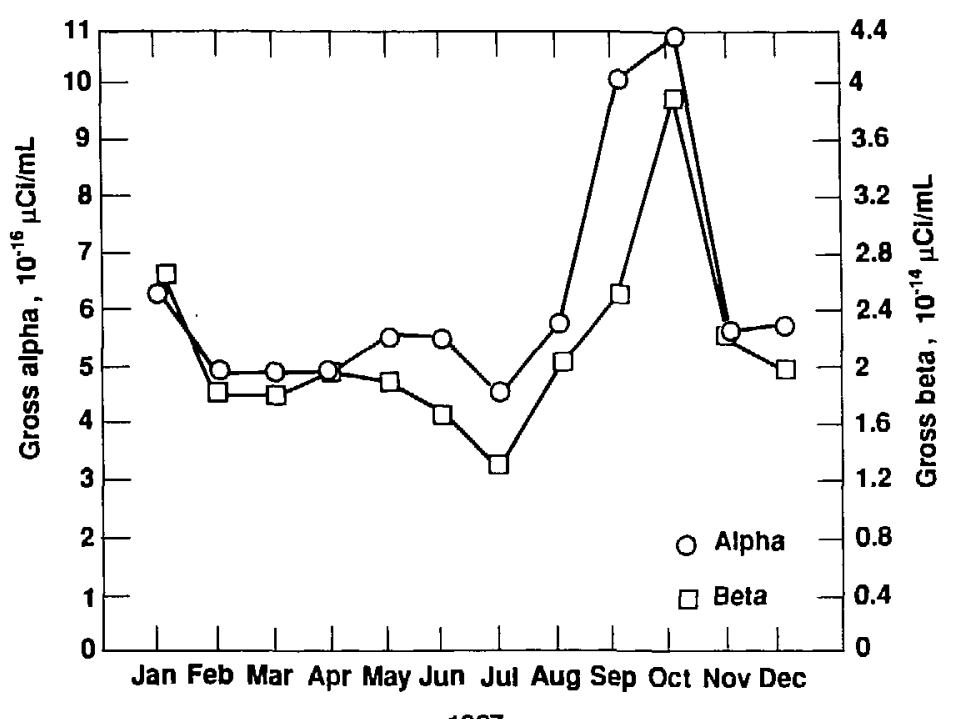

Figure 20. Gross alpha and beta activity on air filters, Livermore Valley. 


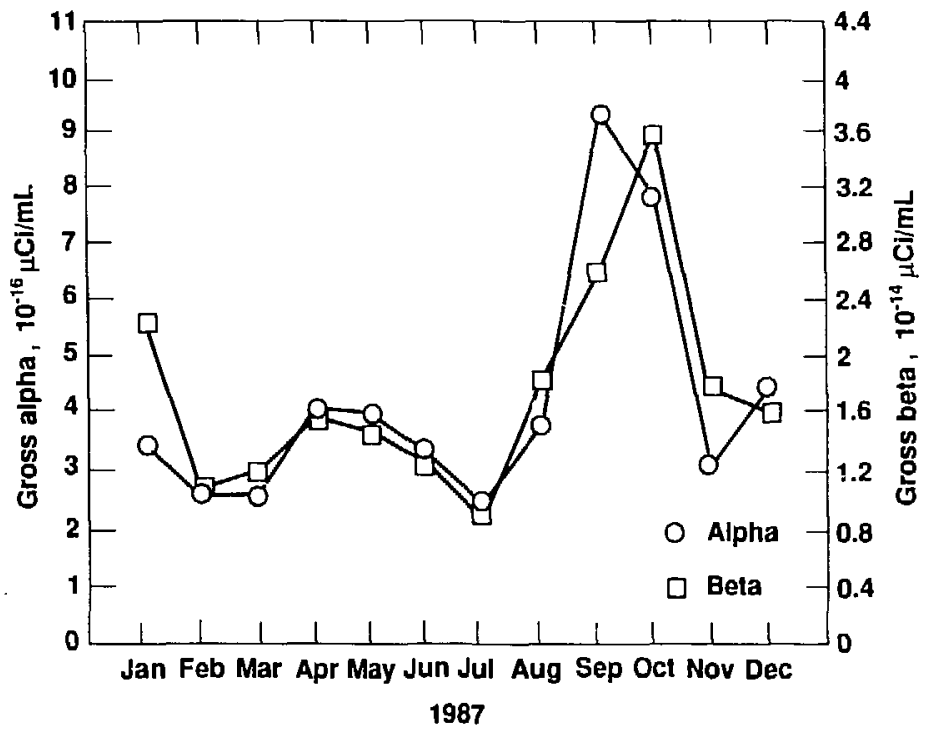

Figure 21. Gross alpha and beta activity on air filters, Site 300.

shows them for Site 300. Analysis for gross alpha and gross beta activity is not required by Federal, State, or local regulations; nor is it required by DOE. LLNL collects these data to ensure that releases of radionuclides other than those specifically analyzed for (see below) will be detected and to identify trends in the LLNL environs. The values reported are similar to those observed in 1986. Gross alpha and gross beta values show no significant differences between samples taken at Site 300, the Livermore site perimeter, and Livermore Valley. Most of the gross alpha determinations were at or near the detection limit of the method. Most of the observed alpha and beta activity results from the naturally occurring radioisotopes of uranium and thorium and their decay products.

Tables A-1 and A-2 list the activities of selected gamma-emitting radionuclides that normally contribute to the gross beta activity in the Livermore site perimeter and Site 300 samples. Of the nuclides tabulated, ${ }^{7} \mathrm{Be}$ and ${ }^{40} \mathrm{~K}$ are naturally occurring. The primary source of the ${ }^{137} \mathrm{Cs}$ is normally long-term global fallout and fallout resuspension; its measurement provides an index of fallout deposition that can be used to evaluate the sources of nuclides, such as ${ }^{239} \mathrm{Pu}$, which could be either from fallout or from LLNL operations.
Other fission products are normally detectable only after such events as atmospheric nuclear tests by other nations or by releases such as the Chernobyl accident. In addition to providing baseline data on global fallout, analysis of these fission products enables LLNL to monitor the containment of the small inventories of mixed fission products and radiochemical tracers used at the Laboratory.

Table A-3 shows the concentration of plutonium on air filter samples collected in Tracy and the Livermore Valley. Tables A-4 and A-5 show the concentrations of airborne ${ }^{239} \mathrm{Pu},{ }^{137} \mathrm{Cs},{ }^{235} \mathrm{U}$, and ${ }^{234} U$ (depleted uranium) in the Livermore site perimeter and Site 300 air samples, respectively. Location 1 at the southeast corner of the Livermore site showed slightly higher concentrations of plutonium in air than the other sample locations. The highest monthly sample was collected during May at location 15. This concentration of $10.85 \times 10^{-17} \mu \mathrm{Ci} / \mathrm{mL}$ represents $0.5 \%$ of the DOE derived concentration guide value (U.S. . Department of Energy, 1987). No other significant differences between locations or samples were noted, and the overall levels determined were essentially the same as those reported in 1986 . Small quantities of ${ }^{234} \mathrm{U}$ are used at Site 300; in years previous 
to 1986 and in 1987 , higher concentrations of this nuclide were obsersed at Site 300 than * the Livermure site perimeter. The 1986 ratios $\mathrm{U}^{-i n} \mathrm{~L}$ showed very little deviation from the concentra. tion in natural uranium. The " $\mathrm{U} / \mathrm{z}$ " $\mathrm{U}$ ratios for two months of 1987 show significant deviations from the natural ratio, indicating the presence of depleted uranium from Site 300 operations. The measured concentrations of ${ }^{274} \mathrm{U}$ are well below the derived concentration guides (U.S. Department of Energy: 1987a).

Table A-6 shows the arerage biweekly tritiated water-vapor concentrations observed at each sampling location; the overal! annual average concentration was $7.0 \times 10^{11} \mu \mathrm{Ci} / \mathrm{mL}$ at the Livermore site perimeter. The highest biweekly concentration occurred in January and was observed at location 2. This concentration, $85.3 \times 10^{11}$ $\mu \mathrm{Ci} / \mathrm{mL}$, is $0.9 \%$ of the DOE standard. Location 14 showed the highest annual average concentration, $10.9 \times 10^{11} \mu \mathrm{Ci} / \mathrm{mL}$. These values were gonerally similar to those reported in other years, except for slightly elevated concentrations at ten locations between January and May.

Elevated tritium values were first observed in the routine analysis of data from September through December 1986. Tritium concentrations in early fall were elevated, then decreased until the last two w'eeks in December, when tritium levels peaked. The highest concentration for 1986 and 1987 was reported during this period at Livermore site perimeter location 14 at $4480 \times 10^{12} \mu \mathrm{Ci} / \mathrm{mL}$. $2.2 \%$ of the DOE derived concentration guides (Department of Energ!; 1987b). Similarly high values were reported at perimeter locations 14 and 15 in that same period. Concentrations of tritium in the first part of 1987 were elevated, but showed a generally decreasing trend until May of 1987. when they reached normal levels.

An investigation of these tritium elevations showed that tritium in vegetation data corroborated tritium in air data, as four locations in the first quarter of 1987 showed values ranging from 3.2 to 20.4 times the peak values reported in 1986 (see the subsection titled "Vegetation and Foodstuff Monitoring"). The locations with the highest values were in the same vicinity as the air samplers showing the highest concentrations. Sample locations showing the highest concentrations were also in the path of the most prevalent wind through the Livermore site and SNLL. A re-analysis of samples showing the highest concentration confirmed the initial values, and discussions with the technical staff ruled out any possibility of sample contamination. The tritium quality-assurance data collected for the tritium monitoring program were evaluated by the LeVG Quality Asburance Program courdinator and were judged as generally good. Thus, lhis portion of I.I.NISt investlgation indicated that the tritium elevation was real.

Stach emission data from tritium-using facilities at the Livernore sit. indicated no unusually large releases of tritium during the periods showing the highest values. SNiLL also indicated that no unusual releases had occurred. LI.NI's investigation revealed no other facilities in the area likely to be using large guantities of tritium. In summary: LLNL measured a significant increase in envirommental tritiated water levels, most likely the result of a large release of tritiated water vapor whose source could not definitely he attribuled to [.LNL or SNLL operations.

Beryllium in Air. Tables $A \cdot 7$ and $A \cdot 8$ show avarage monthly concentrations of airborne beryllium for the Livernore site perimeter and Site 300 (including the City of Tracy) sampling locations. The concentrations, which average less than $1 \%$ of the ambient concentration limit established by the Bay Area Air Quality Management District and the San Joaquin County Air Polluiion Control District, can be attributed to resuspension of surface soil containing naturally occurring beryllium. Local soils contain approximately $1 \mathrm{ppm}$ of beryllium, and Livermore's air typically contains 10 to $100 \mu \mathrm{g}$ of particulates per cubic meter. By using a value of $50 \mu \mathrm{g} / \mathrm{m}^{3}$ for an average dust load and $1 \mathrm{ppm}$ for beryllium content of this dust, an airborne berylIium concentration of $5.0 \times 10^{5} \mu \mathrm{g} / \mathrm{m}^{3}$ can be calculated. In view of the range of natural variation to be expected in these background values, this value is in excellent agreement with the data in Tables A-7 and A-8. The monthly airborne beryllium concentrations for the Livermore site, Site 300, and the City of Tracy are plotted in Fig. 22.

\section{Soil Monitoring}

Table A-9 presents data on the concentrations of ${ }^{214} \mathrm{Pu},{ }^{411} \mathrm{~K},{ }^{137} \mathrm{Cs},{ }^{232} \mathrm{Th}$, and ${ }^{234} \mathrm{U}$ in soil at the Livermore Valley sampling locations. The rationale for including the naturally occurring nuclides ("11 $\mathrm{K},{ }^{232} \mathrm{Th}$, and ${ }^{21 \mathrm{~N}} \mathrm{U}$ ) and the long-lived fission product $\left({ }^{1.5} \mathrm{Cs}\right)$ has been presented above in the subsection "Airborne Radioactivity." The concentrations and distributions observed are within the ranges reported in previous years. Elevated levels of ${ }^{2.34} \mathrm{Pu}$ were first observed in soils near the LWRP during the early 1970 s.

Table A-10 shows the ${ }^{234} \mathrm{Pu},{ }^{41} \mathrm{~K},{ }^{137} \mathrm{Cs}$, and ${ }^{2} \mathrm{H} \mathrm{U}$ activities in the Site 300 samples. Because HE tests 
<smiles>C#CC#CC#C</smiles><smiles>C#CC#CC#CC#C</smiles> 
at Site 300 occasionally involve the use of depleted uranium, one of the purposes of the annual soil samples is to determine how these rests perturb the uranium content of the soil. Uranium measurements were made by gamma spectrometry. As in the past, the analyses indicated that perturbation is essentially limited to areas adjacent to the firing bunkers (Griggs et al., 1986; Gudiksen et al., 1973; and Holland et al., 1987). With the exception of variations in the elevated ${ }^{238} \mathrm{U} \mathrm{cnn}$ centrations near the bunkers, there were negligible changes from activities observed in previous samples collected in the same locations.

\section{Sewage Monitoring}

Radioactivity in Sewage. The concentrations of tritium (as tritiated water), ${ }^{137} \mathrm{Cs}$, and ${ }^{234} \mathrm{Pu}$ measured in the sanitary sewer effluent from LLNL and LWRP are presented in Table A-11. During 1987. there were no inadvertent releases of radioactive materials to the sanitary sewer system that exceeded any discharge limits. The annual average concentration of tritium in the LLNL sanitary sewer effluent was $2.3 \times 10^{\circ} \mu \mathrm{Ci} / \mathrm{mL}$, about $0.02 \%$ of the DOE allowable discharge limit to a public sewer system. The annual average ${ }^{13} \mathrm{Cs}$ concentration of $5.2 \times 10^{-10}$ $\mu \mathrm{Ci} / \mathrm{mL}$ is only $0.003 \%$ of the DOE discharge limit. The concentrations of tritium and ${ }^{137} \mathrm{Cs}$ remain generally consistent with those observed during 1986.

Elevated levels of ${ }^{239} \mathrm{Pu}$ were observed in the LLNL sanitary sewer effluent starting in May, decreasing to near average levels by the end of 1987 . The annual average ${ }^{139} \mathrm{Pu}$ concentration in the sanitary sewer was $1.1 \times 10^{-4} \mu \mathrm{Ci} / \mathrm{mL}$, about $0.008 \%$ of the DOE allowable discharge limit. This represents a 37-fold increase over the 1986 average, but is still well within health and safety standards. Correspondingly, elevated ${ }^{239} \mathrm{Pu}$ levels were observed in effluent and sludge at the LWRP (see Table A-11). The unusually high ${ }^{239} \mathrm{Pu}$ levels are discussed further in a subsequent section, "Environmental Impact of LLNL Operations."

On August 4, 1987, $11000 \mathrm{~L}$ of liquid waste containing small amounts of the radionuclides ${ }^{1{ }^{2} \mathrm{~T}} \mathrm{Ta},{ }^{45} \mathrm{Zr}$, and ${ }^{95} \mathrm{Nb}$ were released to the sanitary sewer system, causing a radiation alarm at the LLNL sewer monitoring station. The highest concentrations of ${ }^{182} \mathrm{Ta},{ }^{95} \mathrm{Zr}$, and ${ }^{95} \mathrm{Nb}$ measured in the waste stream were $2.8 \times 10^{-6}, 1.2 \times 10^{-6}$, and $2.1 \times 10^{-6} \mu \mathrm{Ci} / \mathrm{mL}$, respectively. The $\mathrm{DOE}$ discharge limit to a public sanitary sewer system is $1 \times 10^{-4}, 2 \times 10^{-4}$, and $3 \times 10^{-4} \mu \mathrm{Ci} / \mathrm{mL}$ for ${ }^{t{ }^{2} 2} \mathrm{Ta},{ }^{95} \mathrm{Zr}$, and ${ }^{95} \mathrm{Nb}$, respectively. The entire release was less than $3 \%$ of the limit and well within LLNL guidelines. These rationuclides were not detected by the routine analysis performed pror to a release from a retention tank to the sewer system. More routine analyses are now performed to prevent further occurrences of this nature.

Nonradioactive Pollutants in Sewage. The monthly average metal concentrations in the LLNL sanitary sewer efflient are listed in Table A-12. The results of quarterly monitoring for metals and other physical and themical characteristics of the sanitary sewer effluent are provided in Table A-13. These tables present the average concentration of various parameters and reflect LLNL's usual compliance with the City of Livermore ordinance (Appendix E).

LLNL also has a monitoring alarm system that automatically collects sewer effluent samples if preset warning levels are exceeded. Four such excursions occurred in 1987. Personnel at the LWRP were notified of each of the events before the material reachec the plar:. During two of the events, they chose to divert the influent as a precaution, but returned hoth diversions to the treatment plant waste stream when metal concentrations were confirmed to be normal.

\section{Routine Water Monitoring}

Radioactivity in Water. Tables A-14 and A-15 show the gross alpha activities in Livermore Valley and Site 300 water samples. Gross beta activities for Livermore and Site 300 samples are shown in Tables A-16 and A-17. Gross alpha and beta activities in these surface and domestic water samples collected in 1987 were below EPA and DOHS standards for drinking water (U.S. Environmental Protection Agency, 1977; State of California, 1977). Location 4 , a well near the Site 300 entrance, showed an elevaled gross alpha concentration of $20 \times 10^{-9} \mu \mathrm{Ci} / \mathrm{mL}$ during the first quarter and $25 \times 10^{4} \mu \mathrm{Ci} / \mathrm{mL}$ during the third quarter. Location 3 , another well near the entrance to Site 300 , showed a value of $21 \times 10^{4} \mu \mathrm{Ci} / \mathrm{mL}$ during the third quarter. Location 5 , also a well near the Site 300 entrance, showed a value of $32 \times 10^{-9} \mu \mathrm{Ci} / \mathrm{mL}$ during the third quarter. Location 21, an on-site creek, showed an elevated gross alpha level of $7.2 \times 10^{4} \mu \mathrm{Ci} / \mathrm{mL}$ during the third quarter. Similar observations in the past have been traced to the natural uranium content of the groundwater. The DOHS recommends an action level of $10 \times 10^{4} \mu \mathrm{Ci} / \mathrm{mL}$ and a health advisory level of $40 \times 10^{4} \mu \mathrm{Ci} / \mathrm{mL}$ for natural uranium in srinking water. In the DOHS limit for gross alpha activity, uranium is specifically excluded from the total. The uranium concentrations 
(6) $\times 10^{\circ} \mu \mathrm{Ci} / \mathrm{mL}$ ) were well within those specified by DOE (U.S. Department of Enirgy 1987a) and below the health advisory level recommented by DOHS.

Stormwiter samples were collected at four locations during a major rain early in March: the influent to the Livermore site, effluent to the Arroyo Las Positas, SNLL effluent to the Arroyo 5 eco, and the Livermore site effluent to the Arroyo Seco. The samples sere analyzed for gross alpha, gross beta, tritiated water, and various physical and chemical pollutants.

Table A-18 contains the data for radioactivity in stormwater runoff. All gross alpha concentrations were below the detection limit. Gross beta concentrations did not differ significantly between the LLNL influent and effluent. The highest tritium value was $1.85 \times 10^{\circ} \mu \mathrm{Ci} / \mathrm{ml}$. measured at location 5, which is the outfall to Arroyo Seco, near the southwest corner of LINL. This is a small fraction of the DOE derived concentration guide limit.

Tables A-19 and A-20 show the tritium data for the Livermore Valley and Site 300 samples, respectively. The samples have concentrations that are well below recommended concentration guide values. The highest concentration of tritium in water, $36.3 \times 10^{\circ} \mu \mathrm{Ci} / \mathrm{mL}$, occurred in the Livermore Valley rain (location 20) that was collected during January. This represents $0.2 \%$ of the concentration guide and $20 \%$ of the permissible concentration specified by the DUHS for drinking water (State of California, 1977).

Tables A-19 and A-20 also include an estimate of the annual (effective) dose that may be delivered to an adult who consumes water containing the listed tritium concentrations. These doses, which are all less than 0.1 mrem, are based on a water consumption of $2 \mathrm{~L} / \mathrm{day}$ and the doseconversion factors contained in ICRP 30 (International Commission on Radiological Protection, 1980). The actual dose (if any) from these water sources would be considerably less since they are not used as drinking water sources. Methods used to calculate doses are presented in Appendix $F$.

Data for VOCs and metals from the production wells at Site 300 are covered under the "Compliance Groundwater Monitoring" results subsection of this report, as these wells fall under both sampling regimes.

Results from off-site water monitoring in the vicinity of Site 300 are presented in Table A-21. There are no indications of impacts attributable to Site 300 operations. Most samples were brackish, which is consistent with the marine origin of the
Altamont hills. Ten simples had nitrate levels in (xicess of the $10-\mathrm{mg} / \mathrm{l}$. maximum contaminant le'el (MCL) specified by the DOHS s State of California, 1977). In addition, one sample had lead and one sample had gross beta levels in excess of MCLs. LLNI. helieves the gross beta and nitrate to be of natural origins. The lead may be of natural origins, or it may be an artifact of well equipment installation.

The tritium data for wells in the vicinity of the LWRP and for production wells used b. local water-supply agencies are shown in Table A.22. The highest tritium values appear in wells downgradient of the LWRP. These wells are used to monitor the groundwater quality in the vicinity of the LWRP, and are not used as drinking water sources. Tritium activities in the production wells were at normal hackground levels, and all samples were well below the limits for water adopted by the State of California (1977). The tritium levels in these wells are similar to those observed in the 1986 samples.

In accordance with the CRWQCB, Central Valley Region, Waste Discharge Order No. 80-184, surface water has to be collected at active landfills (Pits 1 and 7) during the rainy season and analyzed for groc, alpha, gross beta, tritium, and beryllium. No samples were collected this year because no tunoff was generated from the landfill sites.

Pollutants in Storm Runoff. Most potential pollutants in the storm runoff were not present at detectable levels. Of those species with measurable concentrations, none exceeded the permissible concentrations set forth in the State of California's regulations for public water supplies (State of California, 1977). Since the runoff is not used for, and does not directly enter any water used for, public supplies, these standards are cited for comparison onlv: The data are shown in Table A-23.

\section{Vegetation and Foodstuff Monitoring}

Table A-24 shows the tritium data for vegetation collected in the Livermore Valley. The effective dose equivalents shown in this table ivere derived using the dose-conversion factors in ICRP 30 (International Commission on Radiological Protection, 1980) and the dose-pathway model from NRC Reg. Guide 1.109 (U.5. Nuclear Regulatory Commission, 1977). Conservatively assuming that an adult's diet includes vegetables with the highest observed average tritium concentration and meat and milk derived from livestock fed on grasses with the same concentration, the maximum fo- $^{-}$ tential dose is approximatrly $0.08 \mathrm{mrem} / \mathrm{y}$. 
Table A-25 shows th: tritium data for Site 300 vegetation. Locations 6 and 13 are adjacent to areas that contain tritium-containing debris from a firing table. As a result of seasonal rains, the tritium is present in the soil and groundwater in the area where these samples are routinely collected. The highest observed concentration (location 13) was $3.9 \times 10^{i} \mu \mathrm{Ci} / \mathrm{mL}$. The calculated annual average dose from v'egetation at this location is 0.3 mrem. using the conservative pathway modeling assumptions. In actuality, this dose would never be received since vegetation at Site 300 is neither consumed directly nor used for grazing livestock. This tritium is further described in the "Special Monitoring Assessments" section of this report.

The data in Table A-26 represent the analy'ses of wine samples purchased in 1987. A comparison of the wines purchased this vear showed that the tritium levels of Livermore Valley wines were somewhat greater than those of California wines produced from grapes grown outside the Vallev. The average tritium level of the Livermore Valley wines was somewhat above that of the European wines sampled, but the ranges overiapped considerably: The levels of tritium measured in Livermore Valley wines represent no health concern.

The data in Table A-27 show that the tritium content of Livermore Valley honey samples is not significantly different than that of honey from neighboring areas.

\section{Milk Monitoring}

The activities of ${ }^{117} \mathrm{Cs}$, ${ }^{41} \mathrm{~K}$, and ${ }^{3} \mathrm{H}$ in goatmilk samples collected this year are shown in Table A-28; no cther nuclides were present at detectable levels. The highest concentration of tritium in milk was $4.3 \times 10^{\prime} \mu \mathrm{Ci} / \mathrm{mL}$. Also shown are the calculated annual whole-body or criticalorgan radiation doses that could be received from consuming this milk. These calculations are based on a milk intake of $310 \mathrm{~L} / \mathrm{y}$ and on the models previously referenced. The dose resulting from ${ }^{3} \mathrm{H}$ (Table A-28) was calculated using dose factors from ICRP 30 (International Commission on Radiological Protection, 1980).

\section{Environmental Radiation Monitoring}

Table A-29 shows the quarterly and annual gamma radiation dose-equivalents for the perimeter locations, and Table A-30 presents data for the off-site locations. When a $T^{\prime} D$ is missing, the annual dose is calculated as four times the average quarterly dose determined from available data. The average annual dose equivalent of $65 \mathrm{mrem}$ at the perimeler daes not differ significantly from the 6t-mrem off-site dererge.

The Tl.Ds measure radiation exposure from all sources of penetrating radiation. These include matural sources (cosmic and terrestrial), fallout from nuclear weapons testing, and any contribution from l.L.NL operations. Based on past measurements (Lindekenl et al., 1973). environmental terrestrial exposure rates in the Livermore Valley vary from 30 to $60 \mathrm{mR} / \mathrm{y}$. Cosmic radiation, calculated from local elevation and geomagnetic latitude according to the data of Lowder and Beck (1966), is about $35 \mathrm{mR} / \mathrm{y}$. The exposures measured at the LLNL perimeter fall within these predicted values. In addition, the external dose rates measured at the LLNL perimeter are identical to the off-site dose rates, which are considered natural background. This indicates that there is no significant contribution to the external dose rate at or beyond the Livermore site fenceline from LLNL operations.

Figure 23 presents the 1987 frequency distribution of environmental gamma dose rates measured at the $\mathbf{5 5}$ off-site locations. The dose rate has remained the same as previous years.

Table A-31 presents the data for the perimeter neutron dosimeters. The highest annual dose occurred at location 3, which historically has had the highest neutron dose rate because of its proximity to the $14-\mathrm{MeV}$ neutron generator in Bldg. 212. The average neutron dose for 1987 was 5 mrem, not significantly higher than the 1986 value.

\section{Noise Monitoring}

There were no complaints of overpressures attributed to LLNL operations at Site 300 during 1987.

\section{Compliance Groundwater Monitoring}

Data for the groundwater monitoring wells at Site 300 (Fig. 24) are presented in Table A-32a. In Pit 1 (Table A-32b), during the first quarter, 0.0012 $\mathrm{mg} / \mathrm{L}$ of mercury and $53 \mu \mathrm{g} / \mathrm{L}$ of TOX were observed in the upgradient well K1-07. These constituents were not observed again in this well for the remainder of the year. There were isolated occurrences of $10 \mu \mathrm{g} / \mathrm{L}$ of a pentane in well $\mathrm{K} 1-03$ during the third quarter and $4 \mu \mathrm{g} / \mathrm{L}$ of toluene in $\mathrm{K} 1.07$ and $26 \mu \mathrm{g} / \mathrm{L}$ of TOX in K1-01C during the fourth yuiuiter Xylenes, which appeared sporadically in 1986 below State of California action levels, were not observed in 1987. The elevated levels of nitrate in the Pit 1 wells have been show'n to be natural constituents of the area groundwater (Budtemeier et al.. 1987a; Carlsen et al., 1987). 


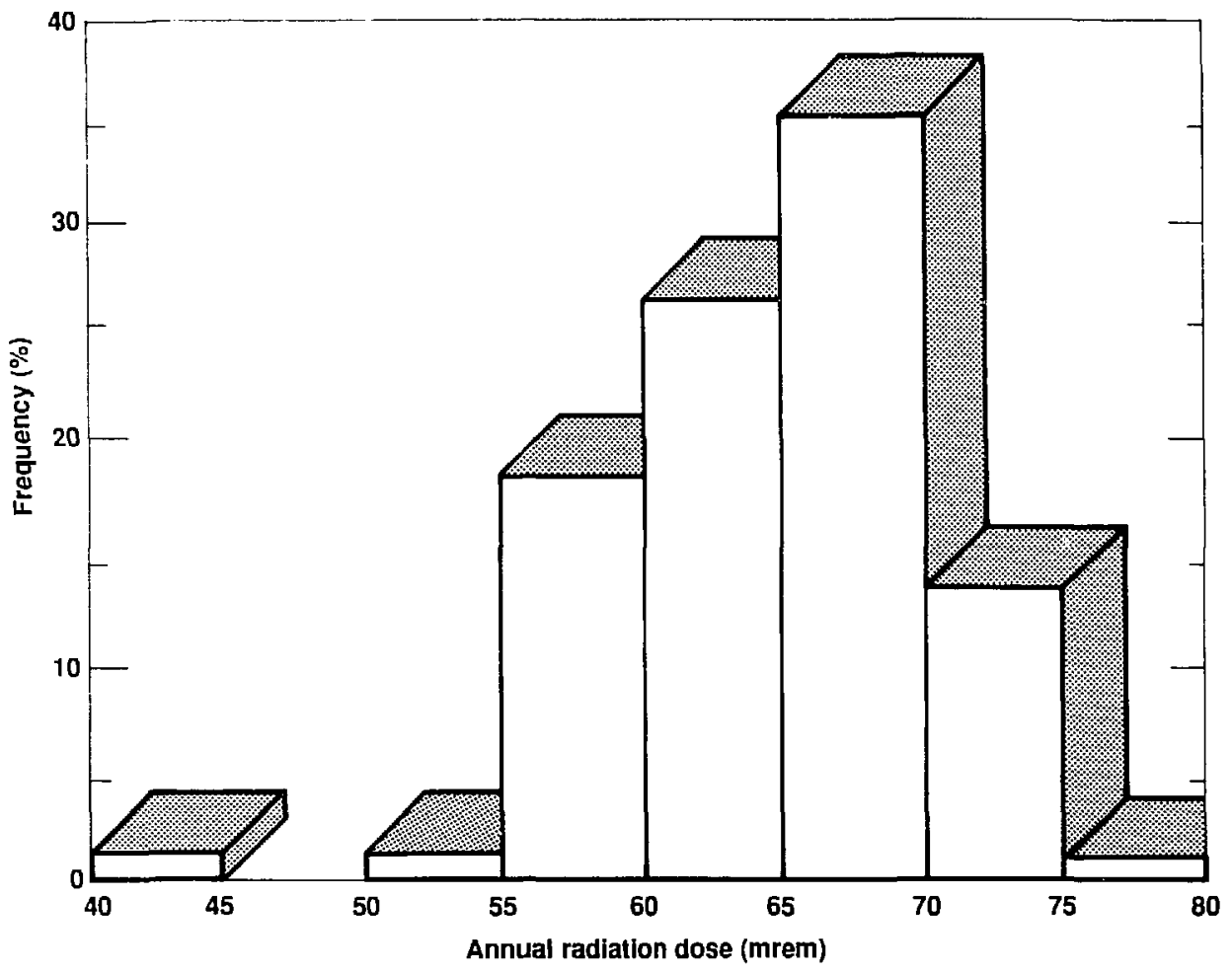

Figure 23. Off-site gamma radiation background.

Table A-32c show's TCE, 1,1-dichloroethylene, and tritium concentrations in the Pit 7 area to be similar to those reported last year. The investigations of TCE and tritium at Site 300 are further discussed in the "Special Monitoring Assessments" section of this report. Trimethyl silanol was observed in well NC7-25 in the second quarter. There were isolated occurrences of very small amounts of purgeable halocarbons in NL7-25 and NC7-47. Trichlorofluoromethane was observed sporadically throughout the year, but never consistently in any one well. Trichlorofluoromethane is a very common laboratory reagent, and its presence is considered to be the result of laboratory contamination.

Table A-32d includes monitoring data from Pit 2 (wells K2-01B, K2-04, K2-04D, and K2-04S), Pit $\tau$ (well K8-01), and well NC2-07. As mentioned abose, the elevated nitrate levels are considered to be natural constituents of this area's groundwater.
In the third and fourth quarters, TCE began to be detected in well K8-01 at the State of California action level of $5 \mu \mathrm{g} / \mathrm{L}$. Additional characterization of this pit is being conducted as part of the continuing investigation of TCE in the soils and groundwater of Site 300. Wells K2-01C and K2045 showed tritium above the $\mathrm{MCL}$, and are part of the Site 300 Tritium Investigation. Both of these investigations are discussed in the "Special Monitoring Assessments" section.

The trace organics observed in Pit 6 well EP6-08 (Table A-32e) during the second quarter returned to below detection limits during the third quarter. Similarly, the trichlorofluoromethane detected in well $\mathrm{Ko}-04$ during the third quarter was not detected in the fourth quarter. TOX in well K6-04, which was slightly elevated in the fourth quarter of 1986, was not observed above detection limits in this well during 1987. Starting in the second quarter and continuing through the fourth 


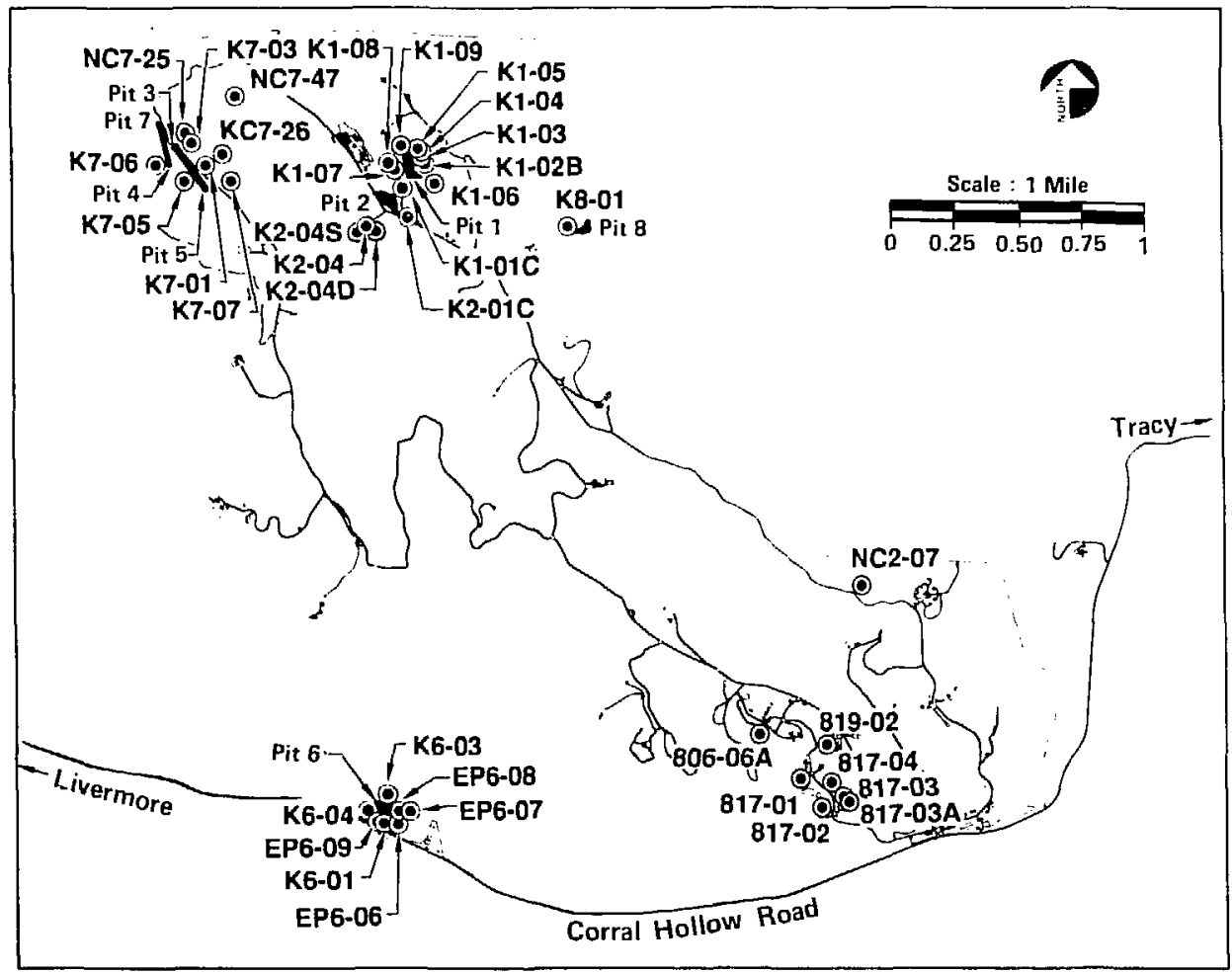

Figure 24. Landrills and monitoring wells, Site 300.

quarter. small amounts of TCE were detected in weil EPG-09. A slight increase in TOX was also observed in this well during these quarters. Further investigation of this TCE occurrence in the vicinity of Pit 6 is planned for 1988.

Data for the HE Process-Water Surface Impoundments are given in Table A-32f. The lysimeters underlying the impoundments produced no water throughout the year. Monitoring well 817-01 continues to show levels of RDX (an HE compound) just ahove the detection limit. Levels of TOX slightly above detection levels continue to be detected in all wells, although inconsistently between quarters. [RCRA mandates that the Stutent's t-tests comparing 1987 TOX concentrations to the 1986 buckground set be performed. These tests show'ed no statistically significant increase in TOX concentrations throughout 1987 (Armstrong and Brown, 1987; Buddemeier et al., 1987a; Brown et al., 1987: and Carlsen et al., 1987).] Elevated nitrate, selenium, and arsenic levels have heen consistenlly detected in all 817 area wells since
1985, and are considered natural constituents of the groundwater (Carlsen et al., 1987). Levels of TCE in excess of the State of California action level were ohserved in wells 817-03 and 817-04 and piezometer $817-03 \mathrm{~A}$. Investigations into the RDX in 817-01 and the TCE occurrences are discussed further in the "Special Monitoring Assessments" section.

Results of org inic and inorganic analyses of the production wells, hoth used and unused, at Site 300 are presented in Table A-32g. Radiological results are presented in Tables A-15, A-17, and A-20 and are discussed in the "Routine Water Monitoring" subsection of this report. Various hydrocarbons were observed in unused production wells 3, 6, and 7. Wells 6 and 7 are in the General Service Area, which is currently part of the TCE investigation. Well 3 is downgradient of Pit 8. As discussed ahove, investigations are planned for 1988 to determine the extent to which this pit may be impacting groundwater quality. 


\section{Environmental Impact of LLNL Operations}

\section{Radioactive Airborne Effluents}

In acoordance with DOE environmental protection urders and other Federal and State requirements, the EOVG assessed the environmental impact irom radiological operations at 1.LNI. during 1458. Fotential ratiation doses to the public were calculated from radionuclide concentrations in envirunmental media (determined by sampling) and emissions of radioactive materials to the atmosphere. The ridiological dose assessment inducted each of the significant ensironmental transport and exposure pathways; inhalation/submersion from the air pathway, ingestion of locally grown fords, and ingestion of drinking water.

In 1987, a total of $2751 \mathrm{Ci}$ of tritiun were released to the atmosphere from operations at L.LNI. Of the $2751 \mathrm{Ci}$ approximately $1329 \mathrm{Ci}$ were released as tritiated water, the quantity used to calculate dose's since the contribution from tritiated hydrogen gas (which comprised the remain. der of the releases) to the dose is insignificant. Approxinntely $570 \mathrm{Ci}$ of tritiated water were released by SNIL; this quantity is not included in dose calculations for LI.NI operations. Releases of the short-lived radionuclides ${ }^{13} \mathrm{~N}-{ }^{15} \mathrm{O}$ from Bldg. 194 (the electron-positron linear accelerator) totalled $+8 \mathrm{Ci}$. An additional $1+\mathrm{Ci}$ of ${ }^{17} \mathrm{~N}-{ }^{17} \mathrm{O}$ were released from the Advanced Test Accelerator (ATA) at Site 300 . This was the total airborne radioactive emission from Site 300. Because of the distance of Site 300 from the livermore site, the dose assessment for site 300 is conducted separately, and is not included with the livermore site doses. Comparative relcases of radioactive effluents at LLNI. (including Site 300 ) during the $7-y$ period from 1981 through 1987 are shown in Table A-33.

During 1987, an open-air experiment was conducted at the ATA. Calculations predicted that small quantities of short-lived ${ }^{17} \mathrm{~N}$ and ${ }^{15} \mathrm{O}$ could he produced by the experiment. Measurements made to monitor the production of activated air indicated trace quantities in the immediate vicinity of the ATA; however, at greater distances from the ATA, still on site, and at the nearest site perimeter, no such traces were detectable.

The DOE requires all contractors to calculate air pathway dose's using the ETA's Clean Air Act Code $(C A A C)$, which contains the AIRDOS-EPA and RADRISK models. I.I.NL has not yet fully tailored the $C A N C$ to site-specific exposure and meteorological parameters. For this reason, the
CAAC Wa" run by Oak Ridge National Laboratory using a variely of assumptions, which were necessary to complete the calculations. In the fu. ture, site-specific meteorology and exposure data will be developed for I.I.NI's use in the CAAC. The results of this calculation are presented in Table A-3ta. We also computed doses using our previous Continuous-Point-Source Code. The results of this calculation are presented in Table A-34h.

The annual average external dose at the Liv(2rmore site houndary (that is, the fence-post dose) was 65 mrem (Tables A-29 and A-31). This dose is not statistically different from the off-site annual average hackground dose of at mrem (Table A-30).

The inhalation/submersion dose calculations are based on the total quantity of radioactive material released to the atmosphere during 1987. These doses and their respective locations are as follows:

- The site boundary: 0.18 mrem.

- The nearest resident: $0.10 \mathrm{mrem}$.

- The maximum off-site exposure: 0.18 mrem.

The maximally exposed individual is a hypothetical member of the public who receives the maximum potential radiation dose from all realistic environmenial exposure pathways. The effective dose equivalent to the hypothetical maximally exposed member of the public was 0.3 mrem (Table A-34c).

The collective population dose to all individuals residing within an $80-\mathrm{km}$ radius of LLNI. was 0.52 person-rem (Table $A-34 d$ ). This dose is based on a population of $6.0 \times 10^{\mathrm{h}}$ within $80 \mathrm{~km}$ of l.L.NI.. Using $100 \mathrm{mrem} / \mathrm{y}$ as a typical average from natural sources, the comparable naturai radiation dose is $6.0 \times 10^{5}$ person-rem.

Table $A-3+$ t compares the dose to the public resulting from LLNL operations with the dose to the public from natural or other background sources. The dose resulting from LLNL operations is negligible.

Appendix $F$ contains definitions of the doses discussed in this subsection and the nuathematical ecpuations used to calculate them.

\section{Radioactive Liquid Effluents}

Facility liquid effluents with the potential of comtaining radionctive materials are routed to retention tanki; they are not discharged directly to the anitary a'wer system. Thend retention tanks 
function to collect potentially contaminaled liquids until a thorough characterization can be performed. When a retention tank hesomes full, a sample of the liquid is analyzed to determine pollutant concentrations. If needed, the wastewater can he trealed at l.LNL's Hazardous Waste Management Facility to reduce radionctivity to the lowest levels reasinably achievalye and well below discharge limits. Once treated and betow acceptable limits (verified by resampling and analysis). the liquid waste in discharged to the City of livermore sanitary sewer system.

Table A-33 summarizes the liquid and airborne releases over the past sevell years. During 1987. a total of $1.4 \mathrm{Ci}$ of tritiated water were discharged to tha sanitary sewer. This anount is well within envirommental protection standards established by DOE, and is within the range reported over the past seven years.

Elevated levels of "Pu were olserved in the L..NI. sanitary sewer effluent during 1987. These measurements were made at the LLNI. sewer monitoring station, located at the sanitary sewer outfall. These samples are a representative fraction of the combined sanitary effluent from the Livermore site. The highest concentration $\left(1.1 \times 10^{*} \mu \mathrm{Ci} / \mathrm{mL}\right)$ occurred in May, followed by decreasing levels through the end of the year.

A total of $6.9 \times 10^{4} \mathrm{Ci}$ of ${ }^{234} \mathrm{Pu}$ was estimated to have been released during 1987. The highest concentration was well below fonly $0 .\left(1080^{\circ}\right)$ the DOE discharge limit for ${ }^{214} \mathrm{Pu}$.

The sanitary sewage from the Livermore site is discharged to the City of Livermore sanitary sewer swstem and treated at the LWRP. Consequently higher than normal levels of ${ }^{234} \mathrm{Pu}$ were also observed in the LWRP effluent and digester sludge (Table A-11). The LWRP composite sample for May had the highest value $\left(8.4 \times 10^{11}\right.$ $\mu(\mathrm{i} / \mathrm{mL}$ ) in 1987 , compared to the 1986 average of $4.0 \times 10^{13} \mu \mathrm{Ci} / \mathrm{mL}$. The second yuarter sludge sample from the LWRP showed a ${ }^{214} \mathrm{Pu}$ concentration of $1 \times 10^{*} \mu \mathrm{Ci} / \mathrm{g}$, compared to $7.7 \times 10^{*}$ $\mu \mathrm{Ci} / \mathrm{g}$ for the first quarter.

The DOE has established limits for discharging radionuclides to a public sewer system. These limits have been derived to adequately protect public health and minimize detriment to the environment; thus these limits are very restrictive. The levels of ${ }^{214} \mathrm{Pu}$ observed in the LLNL effluent during 1987 were substantially below the DOE limit $(0.01 \%)$, representing negligible impact to public health or the environment. Moreover, a release to the sanitary sewer presents even less risk because
If the absence of possitile router of intake. An evaluation has identified the lecation at which the material entered the sewer sytem: howevere the 'xact circumstances behind the release are still be ing investigated.

\section{Nonradioactive Liquid Effluents}

Four incidents of materials in the sanitary sewer system in excess of l.LNL's internal alarm linits were recorded in 1487 . None of these releases resulted in damage to the I.WRR.

On lanuary 6, an LI.N1. employee erronenusly released wastewater from a retention tank before properly neutralizing it. The release, which did not impact the LWRP, caused a high $\mathrm{pH}$ excursion that lasted approximately $25 \mathrm{~min}$. The maximum $\mathrm{pH}$ was 10.6. Appropriate LLNL personnel were reinstructed in proper retention tank release guidelines, and $\mathrm{pH}$ verification procedures were improved to prevent future incidents.

On Octoher 24, approximately 9500 gal of sewage containing slightly elevated concentrations of zinc and chromium were discharged to the sanitary sewer system. As a precaution, LWRP operators diverted the sewage, but returned the material to the waste stream when analysis showed metal concentrations to be normal. The exact cause of the excursion could not be confirmed, but may have been associated with a release from a cooling tower earlier in the day. As a precaution, a new ccoling tower additive was obtained to replace the zinc-containing material previously used in all cooling towers, and a procedure for analyzing the cooling tower water prior to discharge was implemented.

On December 7, an unexplained low $\mathrm{pH}$ of 2.75 was detected in the sanitary sewer. The $\mathrm{pH}$ returned to normal in approximately $6 \mathrm{~min}$. The discharge did not impact the LWRP.

On December 13, approximately $2700 \mathrm{gal}$ of sewage containing elevated levels of copper and zinc were discharged into the sanitary sewer system. The approximately $5 \mathrm{oz}$ of metals were accompanied by a low $\mathrm{pH}$ believed to be due to sulfuric acid. Metal concentrations returned to allowable discharge limits in less than $30 \mathrm{~min}$ and the $\mathrm{pH}$ within $45 \mathrm{~min}$. As a precaution, the LWRP operator diverted approximately $4 \mathrm{~h}$ of influent flow to a retention hasin. Metal concentrations in the diverted flow were determined to be equivalent to normal levels, and the sewage was pumped back into the waste stream for treatment. 
The stormwater runoff showed no detectable level of specified identifiable chlorinated hydrocarbons and only a few other pollutants at detect. able levels. The influent enters LLNL at the east perimeter, and flows into the lake; the effluent exits LLNL. primarily at the northwest comer, with a lesser outflow at the southwest corner.

\section{Grcundwater Quality}

The tritium and TCE in groundwater at Site 300 are considered to has'e minimal adverse im- pact because they have not migrated off site, and the tritium-and TCE-containing aquifers are not used for potable water supplies.

The solvents in groundwater at or near the livermore site are not considered to have any majur atverse impacts since they are not in portions of aquifers that are currently used for pctable water supplies. Corrective actions are being investigated.

\section{Changes to the Environmental Monitoring Program}

During 1987, the Environmental Monitoring Program instituted a number of changes. These changes are permanent in nature and, therefore, differ 'rom the deviations from the sampling program discussed in the next section.

- A comparison between the old air particu. late samplers and a new model was conducted in 1987. The results indicated that no significant hias existed. The new model samplers will gradually be placed in service, replacing the old ones.

- In 1987, milk-sampling locations 8 and 11 were dropped. The owners of the goats informed LLNL of their intention to stop milking the goats. In May, sampling location 12 was added, and in October, sampling location 13 was added.

- Doses at the site perimeter are now calculated to the outer edge of the newly acouired buffer zone.

- The Environmental Monitoring Annual Report was changed as follows:
- Data for gross alpha and gross beta on air filters are now presented in graphs rather than in tabular form.

- Violations brought to LLNL's attention are reported to appropriate regulatory agencies.

- An air emission inventory has been included.

- Several new groundwater monitoring wells were added at the Livermore site, as described in the "Special Monitoring Assessments" section of this report.

- Well K1-06 was officially dropped from the monitoring program at Site 300 because of insufficient water for pumping.

- Wells K2-04S and K2-04D were added at Site 300 to sample the two aquifers sampled by K2-04. Well K2-04 was drilled out and grouted to prevent it from becoming a conduit between the two aquifers.

\section{Deviations from the Sampling Program}

Appendix $G$ lists those regularly scheduled samples for which data is not reported either because of an inability to collect the sample or loss during analysis. Table G-1 lists air particulate de- viations, air tritium deviations, groundwater deviations, vegetation deviations, milk deviations, and environmental radiation monitoring deviations.

\section{Quality Assurance}

On September 18, 1987, the EQVG issued a Quality Assurance Plan (attached as Appendix H). This document meets the requirements of the
American National Standard Institute/American Society of Mechanical Engineers: Resource Conservation Recovery Act; and the Comprehensive 
Envirommental Response, Compensation, and Li. ability Act. It is now being implemented. Implementation is expected to be complete by the end of 1988 . The Quality Assurance Plan sets forth the following data quality goals:

- Accuracy- $\pm 10 \%$ as determined by interlaboratory comparisons or analysis of samples with known concentrations of the parameters of interest

- Precision- $130 \%$ at the $95 \%$ confidence level as determined by the use of duplicate sampling techniques.

- Completeness-data capture (number of samples actually collected divided by the number of samples scheduled to be taken) equal to or greater than 85 o for all sampling media.

In addition to the above requirements, the Data Analysis Procedure" (issued by EQVG as part of the implementation of the Quality Assurance $\Gamma$ lan) requires that a regression analysis be performed on all data from the duplicate sampling regime if more than eight datr pairs are available. Data quality goals for the regression are as follows:

- Correlation coefficient of 0.8 or greater.

- Y-intercept of the regression line of -0.5 to 0.5 .

- Slope of the regression line of 0.9 to 1.1.

During 1987. LLNL participated in the EPA's Environmental Radioactivity Laboratory Intercomparison Studies Program. Table A-35a show's the comparison of analyses by LLNL with the known values and the averages of all the participants. The errors are calculated at the $1 \sigma$ level. The only analyses sutside of the EQVG accuracy goals and the EГA control limits were the gross beta on air filter analyses for the April 20, 1987 and August 28, 1987 intercomparison studies. These gross bota values have been investigated and found to be the result of calibration practices employed by l.I.NI is Hazarts Control Laboratory, which routinely analyzes environmental air filters for gross radicactivity. Since the gross radioactivity numbers are used solely for screening and trending purposes, it is nol considered cost effective to modity the calitration procedures at this time. The ${ }^{\text {h }} \mathrm{Zn}$ in water value was not considered critical since this isotope is not commonly used at II.NI.

LI.NI. also participated in the 1987 intercomparisen study by the DOE Environmental Measurements Laboratory: The data from this study is presented in Table $35 \mathrm{~b}$. Seven of the analyses fall outsicte of the $\pm 10 \%$ accuracy goal. Of these seven, ${ }^{2 w} \Gamma u$ in soil, ${ }^{23} \Gamma \mathrm{r}$ in water. ${ }^{12} \mathrm{Cs}$ in water and : $U$ in air are far enough from the goal to be of concern. These analyses are being investigated by I.I.NL. \& Nuclear Chemistry Division.

Table $\wedge-36$ presents data generated by the duplicate sampling regims. The regression analyses for these sample media where enough data pairs were generated to allow the analyses show good agreement between the routine samples and the quality assurance duplicates, with the exception of the IWR tritium samples. This teviation is considered to be caused by the proximity of the levels to the detection limit. Individual ratios of the quality assurance duplicates to the routine samples do occasionally exceed the data goal of $\pm 30 \%$, but never for a sustained period, which would indicate a bias in the sampling and analysis system. The ratio of 8.51 for 5 ite 300 vegetation is the result of spatial variation in tritium concentrations near areas contaminated with tritium from firingtable debris. It is aiso the result of the need to collect the samples over a large area because of the scarcity of vegetation.

\section{Special Monitoring Assessments}

The following is a brief description of the special monitoring assessments that were initiated or were in progress in 1987 and are being disrussed with State, Federal, or local environmental agencies. Included is a summary of each project. the status of the assessment, and any remedial action as of December 31, 1987. References are cited that give the detailed status of special assessments for which additional reports have heen published.

\section{Livermore Site Groundwater Project}

In 1987, investigations continued to define the extent of VOCs in groundwater and to evaluate various remedial action alternatives. The CRWQCB issued Site Clean-up Orter No. 87-108 to update and replace Waste Discharge Order 85-134.

I.INI. was placed on the National Priorities list on luly 21. 1987. This will bring more EPA 
oversight. Negotiatlons are currently in progress for an inter-agency agreenent corering investigation and remediation activities.

Ficld efforts in 1987 included installation of 53 monitoring wells. completion of 19 two-blay pump tests, testing of experimental remedial water trontment systems, and the installation of a vapor/ water extration well in the Bldg. $4(1.3$ area. These activitien are discusised in monthly progress reporth, which are sulmitled to regulatory agrencies (Dresen et al., 1987a-r; Devany et al., 1987; and Violsiter-Schulten et at., 1987a,b).

In of Decomber 31. 1987 the groundwater momitoring network consisted of 184 LLN1. monitoring wells and 18 private or county wells. The andytical results for samples collected from these wells are presented in the above mentioned monthly progress repurts. Background investigatiom of the use, storage, and disposal of hazardous materials at I.LNI is presented by Dreicer (1985). Recent evidence shows that operations associated sith the former livermore Natal Air Station and its successors. who occupied the LI.NL site from 1942 to 1951 , were major contributors of VOCs in groundwater (U.S. Department of Energy, 1987a).

The current status of various location-specific project phases is discussed below:

\section{Area West of LLNL}

As a result of discussions with the CRWQCB, 11 new monitoring wells were installed west of the southwest corner of L.I.NI. to further define the vertical and horizontal extent of VOCs. As a result of data obtained from these wells, the composite VOC plume is now believed to be $1300 \mathrm{~m}$ ( $4200 \mathrm{ft}$ ) long by $1100 \mathrm{~m}$ (3600 ft) wide by about 3 to $40 \mathrm{~m}(10 \mathrm{to} 120 \mathrm{ft})$ thick, and consists of a main tetrachlorothylene (ГCE) plume and two smaller TCE subplumis.

The main plume is dominated by ГCE at concentrations of up to about $1100 \mathrm{ppb}$ at the apparent source. Analytical data indicating the presence of $\Gamma C E$ in unsaturated soil, collected near the storm sewer discharge in the Arroyo Seco, confirm that storm sewer discharge was the source for the main plume (Veloster-Scholten, 1987b). As previously reported, data indicate that VOCs associated with this source have migrated westward in interfingered northwest-dipping heterogeneous unconsolidated sediments. Near the apparent source of this plume, VOCs are present from $5 \mathrm{~m}$ (16 ft). the approximate depth of the Arroyo Seco channel. to about $50 \mathrm{~m}$ (170 fi). Near the leading edge of the plume, VOCs are not present helow about $60 \mathrm{~m}$ (200 $\mathrm{ft}$ ).
One of the smaller sulpplumes, located mear monitoring well 218, is dominaled by TCE al concentrations up to $590 \mathrm{ppl}^{\mathrm{b}}$. The source is currently believed to have been previous storm sewer discharges into an unlined drainage ditch near the west entrance, or discharge of solvents by the Nayy lo whal were unpaved areas on the west side of the landing mat. This plume extends about $460 \mathrm{~m}(150) \mathrm{ft})$ to the northwest of monitoring well 218, and does not appear to extend below a depth of $40 \mathrm{~m}$ (130 ft).

The other subplume, abo dominated by TCE. appears to have intersected the main plume. The origin of this plune may be past solvent use and disposal practices in the Bletg. 212 and Bldg. 227 areas.

Significant progress was made this year investigating remedial action alternatives. Hydraulic tests indicate that water-hearing sediments have hydraulic conductivities ranging from ahout 0.12 to $61 \mathrm{~m} /$ day (Dresen et al. 1987h). Horizontal hydraulic communication within the same waterbearing zone up to about $615 \mathrm{~m}(2000 \mathrm{ft})$ and vertical conmunication botween water-hearing zones up to alout $15 \mathrm{~m}(50 \mathrm{ft})$ have been observed. An inventory of private wells west of the Livermore site was conducted to help assess the beneficial uses of groundwater near the Livermore site (Dresen et al., 1987a). Modeling efforts using the analytical mass transport model PLUME and the numerical motel SUTRA (Rogers, 1987) are in progress. Rencedial alternatives are discussed in Drese'n et al. (1987h). A proposal for pilut groundwater extraction and treatment west of LLNL was submitted to the CRWQCB, EГA, and DOHS for review:

\section{Southeast LLNL and Vicinity}

Groundwater chemistry and site history indicate that there may have been three sources of VOCs, consisting primarily of TCE (in concentrations up to $2000 \mathrm{ppb}$ ) with differing ratios of other VOCs, which "fingerprint" each source in this area (M.Conachie and Hoffman, 1986; Dresen and Nichols. 1986).

In the Bldg. 518 area, VOCs extend no more than about 60 to $110 \mathrm{~m}$ (200 to $350 \mathrm{ft}$ ) to the west,

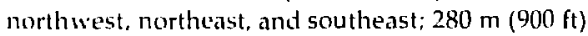
to the southwest, and to depths of less than $50 \mathrm{~m}$ (165 fl).

In the Bldg. 612 yard/Bldg. 514 area evidence of VOCs have been detected. Further plume definition is under was:

Hydratulic tests conducted this year, and dala generated from three new wells, corroborated the 
hrdrogeologic conclusions presented in Dresen and Nichols (1986). Hydraulic conductivities ranging from 0.32 to $11.8 \mathrm{~m} /$ day were olserved. These data, combined with gradient data and an assumed porosity of 0.25 yield an average groundwater velocity of 5.7 to $88.4 \mathrm{~m} / \mathrm{s}$. A summary of well installation and hydraulic testing in the southeast corner of LLNL is given in WebsterSchoiten et al. (1987b) and Dresen et al. (1987a-h).

\section{Gasoline in Soil and Groundwater}

An estimated $65000 \mathrm{~L}$ of gasoline leaked from four underground storage tonks located near Bldg. 40.3 prior to March 1979. Frevious reporting of investigative work conducted in the Bldg. 40.3 area includes Carpenter (1984), Materials (1985). and Dresen et al. (1986). These investigations indicated that concentrations of various gasoline components exceed State and Federal action levels for both soil and groundwater.

Further refinement in assessing the extent of gasoline in soil and ground water continued in 1987 . Unsaturated soil collected in borehole G.5B-15, near the suspected leak, showed up to $11000 \mathrm{ppm}$ of total fuel hydrocarbons (Webster-Scholten, 1987b). Eight new monitoring wells were installed, and new data generated from these wells indicate that fuel hydrocarbons have migrated in groundwater further south than previously reported. Our data indicate that the plume has migrated about $150 \mathrm{~m}(500 \mathrm{ft})$ north, west, and east, and about $250 \mathrm{~m}(800 \mathrm{ft})$ southeast.

During 1987 extensive testing was conducted of spray aeration and vacuum degasifier systems for use in remedial water processing. Discussion of the performance and design of these systems is presented in the above mentioned monthly reports. As a result of our testing, the vacuum degasifier sy'stem appears to be the most appropriate technolngy for removal of gasoline components from groundwater.

An experimental vapor/water extraction well was installed near the leak site to investigate whether gasoline can be removed efficiently in the unsaturated zone using vacuum extraction (WebsterScholten et al., 1987b). Testing of this well is expected to hegin in early 1988.

\section{East Traffic Circle Landfill and Taxi Strip/OId Salvage Yard Areas}

Work is currently under way to determine the extent of VOCs in groundwater in the east traffic circle landfill and the taxi strip/old salvage yard areas. VOCs dominated by TCE in concentrations up to $2800 \mathrm{ppb}$ are present in the groundwater in the east traffic circle landfill area. TCE and FCE are present in groundwater in the taxi strip/old al vage vard area in concentration up to $5800 \mathrm{pp}^{\text {b }}$ and 1300 ppterepectivels: (Ither VOCs appear in lower concentrations. Several hviratulic tests were conducted in this area during 1987.

\section{EG\&G Aerial Survey}

At the request of the DOE Office of Nuclear Safety, EG\&G (Las Vegas. Nevada) conducted radiation-survey overflights ahowe LINI. property and adjacent areas in April 1986. The purpose of the survey was twofold: (1) to document at a given point in time the loxation of areas where ganma radioactivity was detectable and (2) to aid in evaluating the magnitude and spatial extent of contamination from radioactive materials released to the environment (past, present, and future). A similar aerial survey wias conducted at LLNI and adjacent areas in August 1975.

Due to litigation concerning the survey procedures, the final report has not been issued. II.NI. plans to include survey results in the 1988 Environmental Monitoring Annual Report.

\section{TCE at Site 300}

TCE is used as a heat-exchange fluid in the environmental testing facilities and is also provided for shop use. At Site 300. pump and value leaks, system overflows, and housekeeping practices have resulted in TCE spills. TCE has heen fount in soil, rock, and/or water at five locztions at Site 300. Initially; in 1983, 23 exploratory and soil-sampling holes were drilled and 5 groundwater monitoring wells were completed to assess TCE distributions. The surficial two feet $(0.61 \mathrm{~m})$ of soil, containing up to $12000 \mathrm{mg} / \mathrm{kg}$ of TCE, was removed from portions of the Bldg. 834 and Bldg. 854 complexes, aerated, and replaced. The spill areas were covered with PVC sheeting to prevent infiltration and retard further percolation to groundwater (Carpenter et al., 1983). Equipment and housekeeping practices at these complexes have been improved to prevent future spills.

In 1985, following consultation with the CRWQCB, a second phase of studies was initiated. This work included the drilling of 5 additional soil sampling holes at 2 locations within Site 300 and the installation of 11 monitoring wells and piezoneters at 3 locations. Soil and water samples were found to contain up to $160000 \mathrm{ppt}$ of TCE. This work led to the identification of TCE 
in soil at one additional location, the Bldg. 83.3 area. Results of these investigations were reported to the CRWQCB, Central Valley Region, during 1986 (Carpenter et al. 1986).

In an effort to define the distribution of TCE and other VOCs at Site 300. atditional field stud. ies were undertaken during the latter portion of 1986 and during 1987. As a result of this work, 35 additional monitoring wells were drilled and several special purpose borings were completed. The TCE plume at the Bldg. 834 Complex, the area of largest concentration of TCE in groundwater at the site, has been delineated and a feasibility study is heing preparect. Investigations of TCE in soils and groundwater in other areas of Site 300 are continuing. Results are reported quarterly to the CRWQCB. Central Valley Region, and to the DOHS.

\section{Underground Tank Testing}

The LLNL Tank Project monitors and tests all underground tank systems to determine their structural integrity in accordance with the LLNL Tank Testing Program. This program complies with the testing requirements set forth in Title 23 of the California Administratine Code (State of California, 1986), Regienal Water Quality Control Board Waste Discharge orders, and Resource Conservation and Recovery Act regulations for hazardous waste tank systems.

Fifty-one product tank systems (diesel, gas(1line, etc.) were tested in 1987. Three systems failed the leak-tightness test (the precision test required by NFPA Code 329). Sites for potential leakage were discovered in all three systems. All leak sifes were located in the upper portions of the underground piping, ahove the normal operating level of liquid containment. Two of these systems were repaired and put back into service. One system was closed. In all cases, soil contaminated with diesel fuel in concentrations greater than $1000 \mathrm{ppm}$ was removed and disposed of as hazardous waste.

Product tank systems will continue to be monitored and tested on an annual basis. Testing underground portions of wastewater retention systems will resume in 1988 .

\section{Tritium in Groundwater at Site $\mathbf{3 0 0}$}

During 1983 and 1984, increases in tritium concentrations were observed in monitoring wells downgradient from experimental and waste dis- punal areas in the West Firing Area of Site 300. In 1984, concentrations in excess of the state limit for drinking water (2 $\times 10^{4} \mathrm{pCi} / \mathrm{l}$ or $2 * 10^{\circ} \mu \mathrm{Ci} / \mathrm{ml}$ ) were observed in wills $\mathrm{K} 7-(1) 1, \mathrm{~K} 7-(03$, and $\mathrm{K} 2-(01$ (see lig. 22). The CRWOCB, Central Valley Region. was notified and an investigation was initiated. Two antensive reports on the progress of this investigation have been prepared (Buddemeier, 1985: Buddemeier et al., 1987b). The information that follows is summarized from those reports. Table A.32 summarizes the analytical findings resulting from the Site 300 monitoring well program.

Pits 3 and 5 (inative landfills in the Pit 7 complex) have been identified as the sources of one combined plume of tritiun, in groundwater. An extensive drilling program has established bounds on the maximum extent of this plume and installed monitoring wells downgradient of the contaminated areas. The contaminated groundwater in the landfill area is limited to a shallow perched aquifer that is not a present or potential source of potable water supply. Groundwater flow is to the east and northeast, with maximum velocities of a few tens of meters per year; this rate and direction of flow poses no near-term threat to any on-or off-site water supplies. The highest concentration of tritium that has been observed is approximately $1 \times 10^{6} \mathrm{pCi} / \mathrm{L}$ (or $1 \mu \mathrm{Ci} / \mathrm{L}$ ). Concentrations of TCE that are detectable but below the state action level have also been observed in a few wells immediately adjacent to Pit 5 .

$A$ second plume of tritiated water appears to originate in the vicinity of Bldg. 850 , an HE firing area south of the $P$ it 7 complex. The concentrations and near-field hydrogeology of this plume are similar to the landfill plume; however, some tritium appears to have migrated into the East Firing Area, probably by streambed transport from the Bldg. 850 area. The investigation has showr that groundwater tritium found near Pit 2 is not a result of local tritium in the East Firing Area landfills, but is traceable to the 850 plume.

The present phase of the continuing investigation is directed toward improving our estimates of the velocity and direction of groundwater flow and tritium migration and determining the extent of tritium dispersal into East Firing Area groundwater. Through continued monitoring and well drilling, we are investigating the hydrologic effects of the Elk Ravine Fault and the hydrologic connections between the Bldg. 850 tritium source area and tritium plume in the East Firing Area. Results are routinely reported to the CRWQCB, Central Valley Region, and DOHS. 


\section{Burn Pit Operation}

Site 300 operates a burn pit area near Bldg. 829 to hurn waste and paper potentially contaminated with HE. The facility is regulated by the EPA and DOH5 and is operated in accordance with Title 40, Part 265.382, of the Code of Fideral Regulations (Office of the Federal Register, 1986a).

The burn pit area includes three trenches sit uated in a line running from west to east, and one furnace ("iron horse"). The most westerly trench is ecpuipped with a cage and is used to burn paper waste that may he contaminated with HE. The center trench was used in the past to burn pieces of $\mathrm{HE}$. The easterly trench is equipped with a steel pan and is currently used for burning pieces of $\mathrm{HE}$ up to $1 \mathrm{~kg}$ in size. The furnace is used to burn wet $\mathrm{HE}$ fines collected from the HE process water clarifier sy'stems.

An operating plan for the lurn facility has been submitted to the DOHS. To prepare for closure of the existing HE burn facility, between November 1986 and February 1987 we investigated the soils and rocks underlying the pit area. Eight exploratory horings were drilled, one of which was converted to a groundwater monitoring well. Small quantities of HE compounds HMX and RDX as well as minor amounts of VOCs were detected in some of the horings. A summary of the investigation and the analytical results are presented in Ruggieri et al.. 1987.

\section{High-Explosives Wastewater Lagoons and Impoundments, Site 300}

For many years, process water at Site 300's HE formulation, pressing, and machining facilities has been directed through clarifiers and weirs to remove particulate $\mathrm{HE}$. The wastewater was discharged into unlined lagoons.

The industrial wastewater discharged to the lagoons has been tested in past years. Results indicated that effluents are not hazardous, based upon DOHS waste extraction tests (State of California, 1977) and EPA toxicity tests. Fish toxicity tests were also run.

In 1985, duplicate fish toxicity tests were run on effluents from three points in the system: the effluent as it exited the facility, the concrete hox where sludge collects, and the influent to the pond. Survival rates of $100 \%$ of the Pincphale's promelas (fathead minnow) were noted, indicating that the waste stream is nonhazardous.
In 1987, the CRWQCB determined (on the basis of data supplied by L..Nl.) that the wastewater and sludge/sand layer at the bottom of the impoundments are nonhazardous, and therefore the impoundments are not subject to the requirements of the Toxics Pit Cleanup Act. This information has also been supplied to EPA in support of the position that the impoundments are not sulviect to RCRA regulations.

In late 1984. four monitoring wells were installed in the vicinity of the impoundments, as required by Title 23, Chapter 3, Sulchapter 15 of the Califumin Atministratiz' Code' (State of California, 1986) in order to detect any groundwater quality changes arising from future operation of the new surface impoundments. During devtlopment of baseline data and subsequent routir, quarterly monitoring, the presence of small quantsies of an HE compound, RDX, was detected in groundwater samples obtained from the upgradient well. 817-1, in the network (see Fig. 22). As a result of this finding and because of the need to close the abandoned, unlined wastewater lagoons in the HE Processing Area, an investigation was begun during 1986.

Two additional upgradient monitoring wells were drilled during 1986 adjacent to well 817-1. No HE compounds were detected in water samples obtained from these wells. In addition, soil samples were obtained from boreholes at 12 locations within the 806/807 lagoon complex and analyzed for HE compounds. Low levels of the HEs HMX and RDX were detected at most locations, but TNT was detected in trace concentrations in only one sample. The maximum depth of $\mathrm{HE}$ penetration in soil and rock was $70 \mathrm{ft}(21.5 \mathrm{~m})$. The results of the investigation of the $806 / 807$ area were reported to the CRWQCB (Crow et al., 1986).

During late 1986 and 1987, soil samples were obtained from boreholes drilled in the other abandoned HE lagoons. Low levels of HE compounds and metals were detected in most samples (Buddemeier et al.. 1987c,d; Ruggieri et al., 1987).

Data from past and recent sampling were submitted in a report to the CRWQCB, Central Valley Region, to address provisions of the Toxics Pits Cleanup Act (Steenhoven, 1987).

The unlined lagoons were removed from service in 1984 and replaced with two Class II toublelined surface impoundments (evaporation ponds). The new impoundments have a synthetic tiner, underlain by a leachate collection system, and a clay secondary liner. 


\section{Permits and Environmental Evaluations}

During 1987, LLNI. held several environmental permits, orders, and notices that were issued for operations at the Livermore site and at Site 300.

\section{Air Permits}

In 19h. IINI. was issued 163 permits to operate equipment at Livermore and Site 300. The pernits allow the operation of 98 hot water/steam hoilers, 26 degreasers, 11 machine shops (which share a particulate abatement cyclone), 5 diesel fuel storage tanks, 5 paint spray booths, 2 gasoline pump islands, 2 gasoline storage facilities (with tanks), and 14 miscellaneous items. Livernore site permits expire July 1, 1988; Site 300 permits expire January 31. 1989. At the appropriate time LLNL will renew source permits. Livermore site air pollution sources are regulated by the Bay Area Air Quality Management District. The San Joaquin County Air Pollution Control District regulates Site 300 sources. Table I shows emissions for the various permitted sources.

\section{Groundwater Investigation}

As described in the "Special Monitoring Assessments" section of this report, LLNL is currently involved in a comprehensive groundwater investigation in the vicinity of the Livermore site. This investigation has been ongoing since September 1984

Table 1. Emissions by source category (lb per day. ertimated).

\begin{tabular}{|c|c|c|c|c|c|}
\hline & Part. & TOC & No, & SO & $\mathrm{CO}$ \\
\hline \multicolumn{6}{|l|}{ Livermore site } \\
\hline Boilers & 2 & 13 & 97 & & 10 \\
\hline Solvent clcaners & & 70 & & & \\
\hline Paint booths & & 14 & & & \\
\hline Incinerator & 1 & & & & 1 \\
\hline Miscellaneous & & 12 & & & 1 \\
\hline Totals & 3 & 109 & 97 & & 12 \\
\hline \multicolumn{6}{|l|}{ Site 300} \\
\hline Boilers & & & 16 & & 1 \\
\hline Service station & & 0.6 & & & \\
\hline Miscellaneous & & 0.2 & & & \\
\hline Totals & & 0.8 & 16 & & 1 \\
\hline
\end{tabular}

Note: Part. = Particulates, TOG = tolal organic gases (precursors and nonprecursors), $\mathrm{NO}_{3}=$ nitrogen oxides, $\mathbf{S O}_{\mathrm{k}}$ sulfur oxides, and $\mathrm{CO}=$ carbon monoxide.

\section{Liquid Waste Discharge}

An application was submitted to the CRWQCB in 1987 for renewal of Waste Discharge Requirement No. 82-105, whith covers cooling tower blowdown at Situ 300 .

Site Cleanup Order No. 87-108 was issued in 1987 by the Bay Region of the Water Quality Control Buard. This order rescinds Waste Discharge Requirements 85-134 and 86-95, which regulated liquid discharges from the livermore site groundwater investigation.

In 1987 1.l.N1. filed a National Pollution Discharge Elimination System permit application for distharge of groundwater from hydraulic pump tests at the Livermore site.

\section{Solid Waste Landfills}

Eight landfills are covared in Waste Discharge Order No. 80-184 issued by the CRWQCB, Central Valley Region. The two active landfills, Pits 1 and 7 , are also covered by DOHS Interim Status Document, No. CA2890090002. Diversion ditches, groundwater monitoring wells, and lysimeters have been installed to meet the specified requirements. As described in the "Compliance Groundwater Monitoring" methods subsection, the landfills are circled by wells so that changes in groundwater quality can be detected. Some tritium in groundwater has been detected in the Pit 7 area and is attributed to adjacent inactive landfills, Pits 3 and 5 . A discussion of the tritium investigation results can he found in the "Special Monitoring Assessments" section.

TCE in groundwater has been defected in the $\Gamma$ it 7 and HE areas. A discussion of the TCE investigation can he found in the "Special Monitoring Assessments" section.

\section{Other Hazardous Waste Operations}

Both Site 300 and the Livermore site have Interim Status Documents issued hy the DOHS for storage, treatment, and disposal of hazardous wastes. Hazardous waste facilities are heing upgraded, and the design for a new storage and treatment facility is complete. Permit applications for the planned facility have been prepared and submitted to DOHS and the Bay Area Air Quality Management Districl. 
The "Part B" application for the existing incinerator at the Livermore site is currently under review by the EPA and the DOHS. A trial burn is planned. The Operations Plan for the existing storage and treatment facility at the Livermore site was submitted to the DOHS in Decenber 1985; it is still being reviewed.

The "Part B" application for the tandfills at Site 300 designated as Pits 1 and 7 is currently under review by the ERA and the DOHS.

\section{Environmental Impact Report for Contract Renewal}

The University of California renewed its contract with DOE for the operation and management of LLNL. The decision to continue management and operation of LLNL constituted a "project" under the California Environmental Quality Act. Prior to making the decision, the University addressed environmental impacts associated with continuing LLNL activities. The University assessed these impacts through the environmental impact report (EIR) process. The final EIR w is published on July 28, 1987 (University of California, 1987) and certified by the University of Califomia on September 18, 1987.

\section{Environmental Assessments}

The National Environmental Policy Act (NEPA) requires an environmental evaluation to be performed for every new major federal action. This includes all new DOE funded major construction, programs or projects at the Livermore site and Site 300.

Several NEPA documents are in the process of being prepared, reviewed by DOE, or revised to reflect DOE comments. These include Environ- mental Assessments for the High Explosives Application Facility, a research facility with test and diagnostics equipment for performing advanced HE experiments; the Nuclear Directed Energy Research Facility, a facility that will provide an environment for basic research in physics, materials science, and engineering in support of the objectives of the Strategic Defense Initiative; the Nuclear Test Technology Complex, a facility that will house and consolidate LINL's physics and engineering support activities associated with the Nuclear Test Program; and the Environmental Compliance and Cleanup Project, LLNL's environmental remediation project.

In addition, an environmental impact statement (EIS) has been under preparation for the Decontamination and Waste Treatment Facility. a complete, modern facility to process and treat LLNL's radioactive, hazardous, and mixed waste. This EIS has heen reviewed by DOE and was provided to relevant State agencies for review in December 1987. The EIS is being revised to reflect the latest information affecting the projects.

\section{Citations and Agreements}

LLNL was cited by the Bay Area Quality Management District for using paints with a VOC concentration above regulatory limits. A settlement agreement was reached during the summer of 1987.

LLNL. was cited in 1986 by the EPA for violatoris relating to $P C B$ recordkeeping and leaking transformers. A settlement agreement was reached in February, detailing recordkeeping changes and giving a time schedule for the removal of 12 PCB transformers.

In late 1987, a settlement agreement was reached with the DOHS for violations noted during past inspections of Site 300. 
Appendix A. Data Tables 
Table A-1. Gamma activity on air filters-Livermore site perimeter.

\begin{tabular}{|c|c|c|c|c|c|}
\hline & ${ }^{7} \mathrm{Be}$ & ${ }^{40} K$ & ${ }^{137} C_{5}$ & ${ }^{60} \mathrm{Co}$ & ${ }^{125} \mathrm{sb}$ \\
\hline Month & {$\left[10^{-13} \mu \mathrm{Ci} / \mathrm{mL} \pm 2 \sigma(\%)\right]$} & \multicolumn{4}{|c|}{$\left[10^{-16} \mu \mathrm{Ci} / \mathrm{mL} \pm 2 \sigma\left(T_{0}\right)\right]$} \\
\hline Jan. & $1.02 \pm 2$ & $3.32 \pm 70$ & $0.16 \pm 60$ & $-\mathbf{b}$ & $-b$ \\
\hline Feb. & $1.07 \pm 2$ & $-\mathbf{b}$ & $0.15 \pm 64$ & $\mathbf{C}^{\mathbf{b}}$ & $-b$ \\
\hline Mar. & $1.78 \pm 2$ & $7.40 \pm 52$ & $0.19 \pm 38$ & $-\mathbf{b}$ & $-b$ \\
\hline Apr. & $2.26 \pm 2$ & $7.75 \pm 42$ & $0.20 \pm 72$ & $-{ }^{b}$ & $4.59 \pm 56$ \\
\hline May & $1.36 \pm 4$ & $5.95 \pm 28$ & $0.21 \pm 48$ & $0.16 \pm 44$ & $\mathbf{-}^{\mathbf{b}}$ \\
\hline June & $1.37 \pm 2$ & $6.18 \pm 42$ & $0.25 \pm 46$ & $0.16 \pm 68$ & $\ldots$ \\
\hline July & $0.74 \pm 2$ & $7.30 \pm 26$ & $0.21 \pm 56$ & $1.78 \pm 56$ & $\sim^{\mathbf{b}}$ \\
\hline Aug. & $1.31 \pm 2$ & $6.74 \pm 32$ & $-^{\mathbf{b}}$ & $2 B 4 \pm 38$ & $-^{\mathbf{b}}$ \\
\hline Sept. & $1.48 \pm 2$ & $7.11 \pm 46$ & $0.26 \pm 50$ & $-^{\mathbf{b}}$ & $-^{\mathbf{b}}$ \\
\hline Oct. & $1.35 \pm 2$ & $6.63 \pm 34$ & $0.23 \pm 38$ & $-\mathbf{b}$ & $-b$ \\
\hline Nov. & $1.10 \pm 2$ & $2.08 \pm 52$ & $0.11 \pm 34$ & $-\mathbf{b}$ & $-b$ \\
\hline Dec. & $0.84 \pm 2$ & $286 \pm 68$ & $-^{\mathbf{b}}$ & $-^{b}$ & $-{ }^{b}$ \\
\hline Average & 1.31 & 5.75 & 0.20 & 1.24 & $-^{c}$ \\
\hline SDM (F) & 30 & 33 & 22 & 92 & $-^{\mathrm{c}}$ \\
\hline $\operatorname{DCG}(\mu \mathrm{Ci} / \mathrm{mL})$ & $5 \times 10^{-8}$ & $9 \times 10^{-10}$ & $4 \times 10^{-10}$ & $8 \times 10^{-11}$ & $1 \times 10^{-9}$ \\
\hline Percent of DCG & $3 \times 10^{-4}$ & $6 \times 10^{-5}$ & $5 \times 10^{-6}$ & $2 \times 10^{-4}$ & $5 \times 10^{-5}$ \\
\hline
\end{tabular}

All Livermore site perimeter samples composited.

b Nol detected.

c Too small a data set to calculate an average or standard devialion. Percent of DCG is based on largest value. 
Table A-2. Gamma activity on air filters-Site 300.2

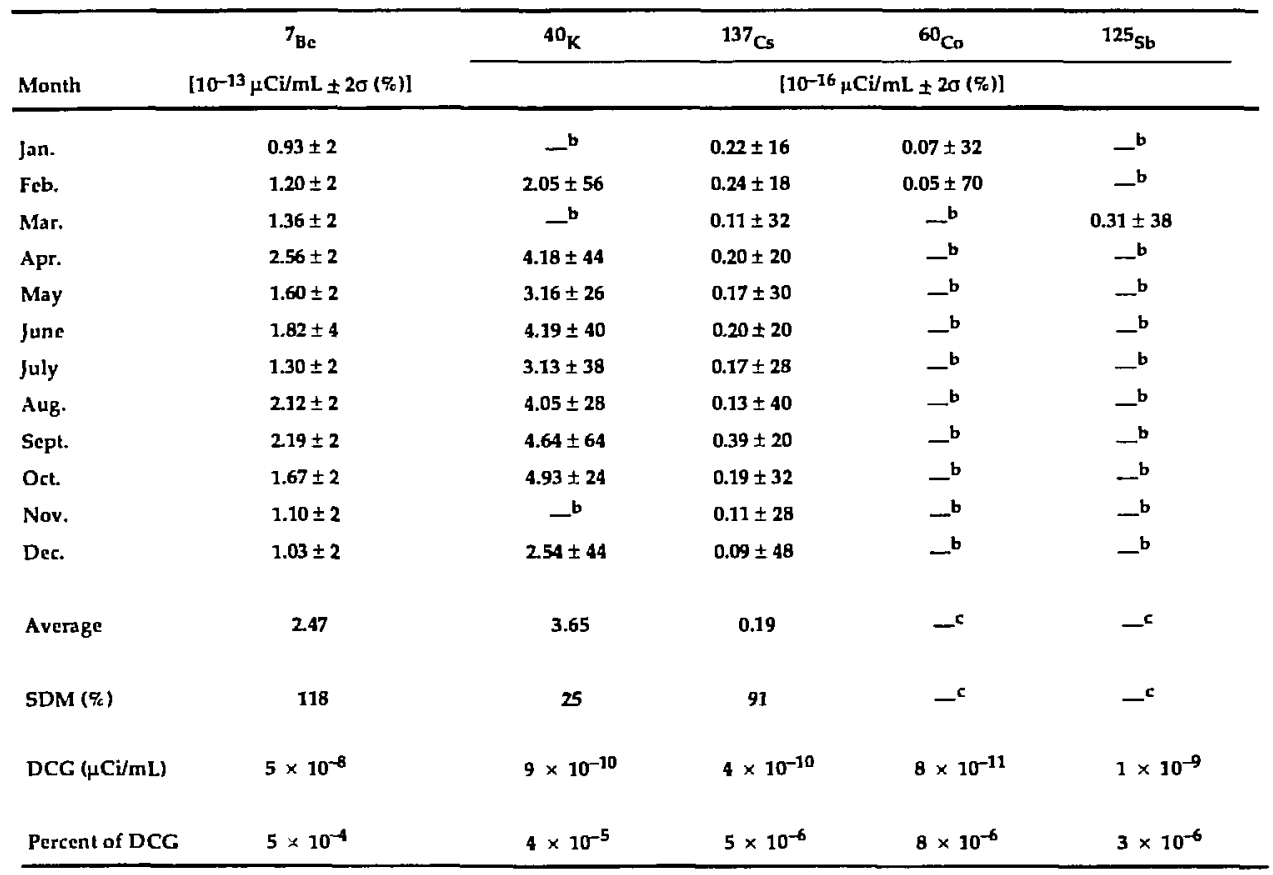

All Site 300 samples composited.

bot detected.

c Too small a data set to calculate an average or standard deviation. Percent of DCG is based on largest value. 
Table A-3. Plutonium-239 on air filters-Livermore Valley.

\begin{tabular}{|c|c|c|c|c|c|c|c|}
\hline \multirow[b]{3}{*}{ Month } & \multicolumn{6}{|c|}{ Sampling location ${ }^{a}$} & \multirow{3}{*}{6} \\
\hline & 3 & 4 & 8 & 10 & 16 & 17 & \\
\hline & \multicolumn{6}{|c|}{$\left[1 \sigma^{-17} \mu \mathrm{Ci} / \mathrm{mL} \pm 2 \sigma\left(q_{c}\right)\right]$} & \\
\hline Jan. & $0.01 \pm 50$ & $0.01 \pm 71$ & $\leq 0.01$ & $\leq 0.01$ & $0.02 \pm 50$ & $0.02 \pm 42$ & $\leq 0.01$ \\
\hline Feb. & $0.02 \pm 58$ & $0.02 \pm 41$ & $\leq 0.01$ & $0.03 \pm 34$ & $0.03 \pm 45$ & $\leq 0.01$ & $\leq 0,01$ \\
\hline Apr. & $0.01 \pm 46$ & $0.04 \pm 21$ & $0.02 \pm 29$ & $0.03 \pm 26$ & $0.02 \pm 40$ & $0.03 \pm 35$ & $0.03 \pm 38$ \\
\hline May & $0.04 \pm 29$ & $0.02 \pm 49$ & $0.03 \pm 43$ & $0.02 \pm 47$ & $0.06 \pm 20$ & $0.03 \pm 43$ & $0.01 \pm 73$ \\
\hline June & $0.06 \pm 29$ & $0.52 \pm 9^{b}$ & $0.01 \pm 60$ & $0.03 \pm 28$ & $0.01 \pm 48$ & $0.03 \pm 41$ & $0.03 \pm 46$ \\
\hline July & $0.02 \pm 50$ & $0.04 \pm 21$ & $0.03 \pm 32$ & $0.01 \pm 51$ & $0.04 \pm 27$ & $\leq 0.01$ & $0.05 \pm 22$ \\
\hline Nov. & $\leq 0.01$ & $0.01 \pm 65$ & $\leq 0.01$ & $0.02 \pm 41$ & $0.04 \pm 37$ & $\leq 0.01$ & $0.01 \pm 81$ \\
\hline Dec. & $0.03 \pm 55$ & 50.01 & $0.06 \pm 34$ & 50.01 & $0.08 \pm 26$ & $0.03 \pm 39$ & $\leq 0,01$ \\
\hline \multirow[t]{2}{*}{ Average } & 0.04 & $(0.10)^{b}$ & 0.02 & 0.02 & 0.04 & 0.03 & 0.04 \\
\hline & & 0.05 & & & & & \\
\hline \multirow[t]{2}{*}{$\operatorname{SDM}(\%)$} & 103 & $(166)^{b}$ & 74 & 47 & 57 & 17 & 80 \\
\hline & & 121 & & & & & \\
\hline Percent of DCG & $2 \times 10^{-3}$ & $\begin{array}{l}\left(5 \times 10^{-3}\right)^{b} \\
2.5 \times 10^{-3}\end{array}$ & $1 \times 10^{-3}$ & $1 \times 10^{-3}$ & $2 \times 10^{-3}$ & $1.5 \times 10^{-3}$ & $2 \times 10^{-3}$ \\
\hline
\end{tabular}

See Fig. 7 for sampling locations. Location 6 is in the City of Tracy.

b Outlier. Values with outlier included are in parentheses.

c DCG for $\mathrm{Pu}$ in air $=2 \times 10^{-14} \mu \mathrm{Ci} / \mathrm{mL}$ or $2 \times 10^{-2} \mathrm{pCi} / \mathrm{m}^{3}$. 
Table A-4. Plutonium and uranium on air filters - Livermore site perimeter.

\begin{tabular}{|c|c|c|c|c|c|}
\hline Month & Location" & $\begin{array}{c}{ }^{239} \mathrm{Pu}^{\mathrm{b}} \\
{\left[10^{-17} \mu \mathrm{Ci} / \mathrm{mL}\right]}\end{array}$ & {$\left[1 \sigma^{-7} \mu g^{2} m^{3}\right]$} & {$\left[10^{-5} \mu \mathrm{g} / \mathrm{m}^{3}\right]$} & $\begin{array}{r}\left.{ }^{235} U\right)^{238} U \\
{\left[10^{-3}\right]}\end{array}$ \\
\hline \multirow[t]{6}{*}{ Jan. } & 1 & $0.04 \pm 58$ & 3.64 & 5.10 & 7.1 \\
\hline & 2 & $0.03 \pm 39$ & 3.02 & 4.33 & 7.0 \\
\hline & 12 & $0.01 \pm 58$ & 3.61 & 5.32 & 6.8 \\
\hline & 13 & $0.01 \pm 63$ & 3.62 & 5,08 & 7.1 \\
\hline & 14 & $0.02 \pm 28$ & 2.64 & 3.64 & 7.3 \\
\hline & 15 & $0.04 \pm 19$ & 2.94 & 4.14 & 7.1 \\
\hline \multirow[t]{6}{*}{ Feb. } & 1 & $0.01 \pm 30$ & 0.39 & 0.43 & 9.0 \\
\hline & 2 & $0.08 \pm 20$ & 2.80 & 3.93 & 7.1 \\
\hline & 12 & $0.04 \pm 35$ & 3.71 & 5.34 & 6.9 \\
\hline & 13 & $\leq 0.01$ & 3.07 & 4.35 & 7.1 \\
\hline & 14 & $0.02 \pm 48$ & 1.96 & 2.79 & 7.0 \\
\hline & 15 & $0.03 \pm 29$ & 3.43 & 4.86 & 7.1 \\
\hline \multirow[t]{6}{*}{ Mar. } & 1 & $0.77 \pm 7$ & 4.76 & 6.60 & 7.2 \\
\hline & 2 & $0.01 \pm 42$ & 2.90 & 4.18 & 6.9 \\
\hline & 12 & $0.03 \pm 39$ & 4.66 & 6.70 & 7.0 \\
\hline & 13 & $s^{0.01}$ & 4.46 & 6.38 & 7.0 \\
\hline & 14 & $0.02 \pm 43$ & 2.41 & 3.45 & 7.0 \\
\hline & 15 & $0.02 \pm 51$ & 9.46 & 13.30 & 7.0 \\
\hline \multirow[t]{6}{*}{ Apr. } & 1 & $0.99 \pm 9$ & 8.81 & 12.40 & 7.1 \\
\hline & 2 & $0.03 \pm 31$ & 5.86 & 8.14 & 7.2 \\
\hline & 12 & $0.26 \pm 21$ & 8.41 & 12.00 & 7.0 \\
\hline & 13 & $0.04 \pm 54$ & 9.45 & 13.20 & 72 \\
\hline & 14 & $0.07 \pm 32$ & 5.55 & 7.74 & 72 \\
\hline & 15 & $0.11 \pm 25$ & 11.10 & 15.50 & 72 \\
\hline \multirow[t]{6}{*}{ May } & 1 & $0.57 \pm 10$ & 7.29 & 10.28 & 7.1 \\
\hline & 2 & $0.04 \pm 26$ & 4.06 & 5.69 & 7.1 \\
\hline & 12 & $0.14 \pm 24$ & 6.83 & 10.01 & 6.8 \\
\hline & 13 & $0.02 \pm 59$ & 6.97 & 9.96 & 7.0 \\
\hline & 14 & $0.06 \pm 25$ & 4.03 & 5.69 & 7.1 \\
\hline & 15 & $10.85^{C} \pm 3$ & 7.58 & 10.85 & 7.0 \\
\hline \multirow[t]{6}{*}{ June } & 1 & $0.47 \pm 6$ & 6.51 & 9.31 & 7.0 \\
\hline & 2 & $0.01 \pm 37$ & 3.43 & 4.80 & 7.1 \\
\hline & 12 & $0.08 \pm 30$ & 7.33 & 10.44 & 7.0 \\
\hline & 13 & $0.04 \pm 23$ & 11.71 & 16.52 & 7.1 \\
\hline & 14 & $0.09 \pm 14$ & 4.00 & 5.62 & 7.1 \\
\hline & 15 & $0.04 \pm 28$ & 5.96 & 8.40 & 7.1 \\
\hline
\end{tabular}


Table A-4. (Continued).

\begin{tabular}{|c|c|c|c|c|c|}
\hline Month & Location & {$\left[\begin{array}{c}{ }^{239} \mathrm{Pu}^{b} \\
{\left[10^{-17} \mu \mathrm{Ci} / \mathrm{mL} .\right]}\end{array}\right.$} & ${ }_{\left[10^{-7} \mu \mathrm{g} / \mathrm{m}^{3}\right)}^{235}$ & $\begin{array}{c}{ }^{238} \mathrm{U} \\
{\left[1 \sigma^{-5} \mu \mathrm{g} / \mathrm{m}^{3}\right]}\end{array}$ & $\begin{array}{c}{ }^{235} U /^{238} U \\
{\left[10^{-3}\right]}\end{array}$ \\
\hline \multirow[t]{6}{*}{ July } & 1 & $0.53 \pm 7$ & 6.76 & 9.62 & 7.0 \\
\hline & 2 & $0.01 \pm 41$ & 3.14 & 4.35 & 72 \\
\hline & 12 & $0.04 \pm 35$ & 5.7 & 8.35 & 6.9 \\
\hline & 13 & $0.11 \pm 22$ & 9.09 & 12.75 & 7.1 \\
\hline & 14 & $0.15 \pm 13$ & 4.51 & 6.40 & 7.0 \\
\hline & 15 & $0.14 \pm 15$ & 7.07 & 10.09 & 7.0 \\
\hline \multirow[t]{6}{*}{ Aug. } & 1 & $1.84 \pm 5$ & 11.75 & 16.50 & 7.1 \\
\hline & 2 & $0.02 \pm 28$ & 3.82 & 5.34 & 7.1 \\
\hline & 12 & $0.04 \pm 43$ & 8.94 & 12.72 & 7.0 \\
\hline & 13 & $0.06 \pm 33$ & 9.51 & 13.35 & 7.1 \\
\hline & 14 & $0.06 \pm 27$ & 5.41 & 7.66 & 7.1 \\
\hline & 15 & $0.06 \pm 30$ & 7.02 & 9.96 & 7.1 \\
\hline \multirow[t]{6}{*}{ Sept. } & 1 & $0.38 \pm 11$ & 6.16 & 8.68 & 7.1 \\
\hline & 2 & $0.02 \pm 43$ & 4.66 & 6.52 & 7.1 \\
\hline & 12 & $0.10 \pm 25$ & 8.45 & 12.00 & 7.0 \\
\hline & 13 & $0.04 \pm 48$ & 1200 & 16.90 & 7.1 \\
\hline & 14 & $0.15 \pm 17$ & 5.90 & 8.28 & 7.1 \\
\hline & 15 & $0.58 \pm 9$ & B.96 & 12.60 & 7.1 \\
\hline \multirow[t]{6}{*}{ Oct. } & 1 & $0.30 \pm 8$ & 6.00 & 8,44 & 7.1 \\
\hline & 2 & $0.03 \pm 24$ & 4.51 & 6.33 & 7.1 \\
\hline & 12 & $0.08 \pm 16$ & 8.54 & 12.06 & 7.1 \\
\hline & 13 & $0.06 \pm 22$ & 7.52 & 10.58 & 7.1 \\
\hline & 14 & $0.06 \pm 20$ & 5.60 & 7.91 & 7.1 \\
\hline & 15 & $0.07 \pm 20$ & 10.53 & 14.90 & 7.1 \\
\hline \multirow[t]{6}{*}{ Nov. } & 1 & $0.05 \pm 23$ & 1.74 & 2.52 & 6.9 \\
\hline & 2 & $0.03 \pm 26$ & 2.16 & 3.10 & 7.0 \\
\hline & 12 & $0.10 \pm 15$ & 5.21 & 7.43 & 7.0 \\
\hline & 13 & $0.02 \pm 54$ & 3.17 & 4.61 & 6.9 \\
\hline & 14 & $0.04 \pm 33$ & 2.14 & 3,09 & 6.9 \\
\hline & 15 & $0.04 \pm 34$ & 6.67 & 9.48 & 7.0 \\
\hline \multirow[t]{6}{*}{ Dec. } & 1 & $0.07 \pm 21$ & 4.5 & 6.38 & 7.1 \\
\hline & 2 & $0.02 \pm 30$ & 4.43 & 6.24 & 7.1 \\
\hline & 12 & $0.08 \pm 20$ & 7.38 & $10.4]$ & 7.1 \\
\hline & 13 & $0.02 \pm 45$ & 5.52 & 7.43 & 7.4 \\
\hline & 14 & $0.05 \pm 24$ & 4.40 & 6.19 & 7.1 \\
\hline & 15 & $0.05 \pm 26$ & 6.42 & 9.01 & 3.1 \\
\hline
\end{tabular}


Table A-4, (Continued).

\begin{tabular}{|c|c|c|c|c|c|c|c|c|c|}
\hline \multicolumn{4}{|c|}{ Annual ayerages } & \multicolumn{3}{|c|}{${ }^{235} \mathrm{U}$} & \multicolumn{3}{|c|}{${ }^{238} \mathbf{U}$} \\
\hline Location & $10^{-17} \mu \mathrm{Ci} / \mathrm{mL}$ & $\operatorname{SDM}(\%)$ & Percent of DCGd & $1 \sigma^{-7} \mu g^{\prime} \mathrm{m}^{3}$ & $\operatorname{SDM}(\%)$ & Percent of DCG & $10^{-5} \mu g^{\prime} \mathrm{m}^{3}$ & $\operatorname{SDM}(\%)$ & Percent of DCG' \\
\hline 1 & 0.50 & 104 & 0.025 & 5.69 & 54 & 0.0012 & 8.02 & 54 & 0.027 \\
\hline 2 & 0.03 & 70 & 0.0014 & 3.73 & $\mathbf{2 7}$ & 0.0008 & 5.25 & 27 & 0.017 \\
\hline 12 & 0.08 & 80 & 0.0042 & 6.57 & 30 & 0.0014 & 9.4 & 28 & 0.031 \\
\hline 13 & 0.04 & 70 & 0.0021 & 7.17 & 45 & 0.0015 & 10.01 & 45 & 0.034 \\
\hline 14 & 0.07 & 68 & 0.0033 & 4.05 & 36 & 0.0009 & $5 . n$ & 36 & 0.019 \\
\hline \multirow[t]{2}{*}{15} & $(1)^{\mathbf{c}}$ & $(309)^{c}$ & $(0.05)^{c}$ & 7.26 & 35 & 0.0016 & 10.26 & 35 & 0.034 \\
\hline & 0.11 & 143 & 0.0054 & & & & & & \\
\hline
\end{tabular}

See Fig. 5.

b In all tables, activity listed as $239 \mathrm{Pu}$ includes activity due to $240 \mathrm{Pu}$.

c Outlier. Values with outlier included are in parentheses.

d $D C G=2 \times 10^{-14} \mu \mathrm{Ci} / \mathrm{mL}$ for $239 \mathrm{Pu}$ activity in air or $2 \times 10^{-2} \mathrm{pCi} / \mathrm{m}^{3}$.

- $D C G=1 \times 1 \sigma^{-13} \mu \mathrm{Ci} / \mathrm{mL}\left(=0.047 \mu \mathrm{g} / \mathrm{m}^{3}\right)$ for $235 \mathrm{U}$ activity in air.

f DCG $=1 \times 10^{-13} \mu \mathrm{Ci} / \mathrm{mL}\left(=03 \mu \mathrm{g} / \mathrm{m}^{3}\right)$ for ${ }^{238} \mathrm{U}$ activity in air. 
Table A-5. Plutonium, cesium, and uranium on air filters-Site 300 .

\begin{tabular}{|c|c|c|c|c|c|c|}
\hline Month & $\frac{{ }^{239} \mathrm{Pu}}{\left[10^{-17} \mu \mathrm{Ci} / \mathrm{mL} \pm 20(\%)\right]}$ & $\begin{array}{c}{ }^{137} \mathrm{Cs} \\
{\left[1 \sigma^{-16} \mu \mathrm{Ci} / \mathrm{mL}\right]}\end{array}$ & $\begin{array}{c}\left.{ }^{239} \mathrm{Pu}\right|^{137} \mathrm{Cs} \\
\left|10^{-2}\right|\end{array}$ & $\stackrel{235}{\left[1 \sigma^{7} \mu \mathrm{g} / \mathrm{m}^{3}\right]}$ & $\stackrel{{ }^{238} \mathrm{U}}{\left[10^{-5} \mu \mathrm{g}^{\prime} \mathrm{m}^{3}\right]}$ & $\begin{array}{c}{ }^{235} \mathrm{U}^{238} \mathrm{U} \\
{\left[10^{-3}\right]}\end{array}$ \\
\hline Jan. & $0.03 \pm 8$ & $0.22 \pm 16$ & 1.4 & 1.0 & 1.5 & 6.4 \\
\hline Feb. & $0.05 \pm 18$ & $0.24 \pm 18$ & 2.1 & 1.0 & 1.5 & 6.7 \\
\hline Mar. & $0.02 \pm 13$ & $0.11 \pm 32$ & 1.8 & 1.4 & 2.3 & 6.0 \\
\hline Apr. & $0.08 \pm 13$ & $0.20 \pm 20$ & 4.0 & 6.1 & 8.9 & 6.8 \\
\hline May & $\leq 0.27$ & $0.17 \pm 30$ & 15.9 & 5.4 & 14.1 & 3.8 \\
\hline June & $0.04 \pm 7$ & $0.20 \pm 20$ & 2.0 & 3.6 & 5.5 & 6.5 \\
\hline July & $0.05 \pm 7$ & $0.17 \pm 28$ & 2.9 & 2.9 & 4.3 & 6.8 \\
\hline Aug. & $0.03 \pm 10$ & $0.13 \pm 40$ & 2.3 & 4.1 & 5.8 & 7.0 \\
\hline Sept. & $0.08 \pm 9$ & $0.39 \pm 20$ & 2.1 & 5.0 & 7.1 & 7.0 \\
\hline Oct. & $0.10 \pm 5$ & $0.19 \pm 32$ & 5.3 & 5.2 & 7.5 & 6.9 \\
\hline Nov. & $0.16 \pm 5$ & $0.11 \pm 28$ & 14.5 & 5.9 & 23.4 & 2.5 \\
\hline Dec. & $0.04 \pm 7$ & $0.09 \pm 48$ & 4.4 & 4.6 & 6.8 & 6.8 \\
\hline Average & 0.08 & 0.19 & & 3.9 & 7.4 & \\
\hline $\operatorname{SDM}(\%)$ & 90 & 42 & & 49 & 83 & \\
\hline $\mathrm{DCG}(\mu \mathrm{Ci} / \mathrm{mL})$ & $2 \times 10^{-14}$ & $4 \times 10^{-10}$ & & $4.7 \times 10^{-2} \mu \mathrm{g} / \mathrm{m}^{3}$ & $0.3 \mu g / \mathrm{m}^{3}$ & \\
\hline Percent of DCG & $4 \times 10^{-3}$ & $5 \times 10^{-6}$ & & $8 \times 10^{-4}$ & $2 \times 10^{-2}$ & \\
\hline
\end{tabular}


Table A-6a. Tritium in air-Livermore site perimeter.

\begin{tabular}{|c|c|c|c|c|c|c|}
\hline \multirow[b]{3}{*}{ Month } & \multicolumn{6}{|c|}{ Sampling locationa } \\
\hline & 1 & 2 & 12 & 13 & 14 & 15 \\
\hline & \multicolumn{6}{|c|}{$\left[10^{-11} \mu \mathrm{Ci} / \mathrm{mL} \pm 2 \sigma\left(q_{*}\right)\right]$} \\
\hline Jan. & $-^{b}$ & $\begin{array}{c}3.2 \pm 3 \\
85.3 \pm 7^{c}\end{array}$ & $\begin{array}{l}6.6 \pm 2 \\
8.0 \pm 2\end{array}$ & $\begin{array}{l}4.3 \pm 3 \\
6.2 \pm 2\end{array}$ & $\begin{array}{c}-^{b} \\
1.6 \pm 1^{d} \\
1.6 \pm 4^{d}\end{array}$ & $\begin{array}{l}3.2 \pm 3 \\
1.6 \pm 4\end{array}$ \\
\hline Feb. & $\begin{array}{l}41.6 \pm 1 \\
53.9 \pm 1^{c}\end{array}$ & $\begin{array}{l}7.8 \pm 2 \\
6.3 \pm 2\end{array}$ & $\begin{array}{l}15.2 \pm 1 \\
64.8 \pm 1^{c}\end{array}$ & $\begin{array}{c}6.8 \pm 1^{c} \\
\text { - }^{\mathrm{c}}\end{array}$ & $\begin{array}{c}10.6 \pm 2 \\
109.1 \pm 1 c, d \\
2.0 \pm 4\end{array}$ & $\begin{array}{l}6.4 \pm 2 \\
2.0 \pm 4\end{array}$ \\
\hline Mar. & $\begin{array}{l}9.9 \pm 2 \\
6.6 \pm 2^{d} \\
3.4 \pm 4 \\
2.6 \pm 4^{d}\end{array}$ & $\begin{array}{l}3.7 \pm 3 \\
2.2 \pm 4\end{array}$ & $\begin{array}{r}13.2 \pm 2 \\
7.0 \pm 2\end{array}$ & $--^{b}$ & $\begin{array}{l}8.2 \pm 2 \\
3.0 \pm 4\end{array}$ & $\begin{array}{c}25.3 \pm 1^{c} \\
3.6 \pm 3\end{array}$ \\
\hline Apr. & $\begin{array}{c}15.2 \pm 1 \\
7.9 \pm 2^{d} \\
2.6 \pm 5 \\
2.1 \pm 5^{d}\end{array}$ & $\begin{array}{l}4.5 \pm 3 \\
5.6 \pm 3^{d} \\
2.6 \pm 3 \\
4.6 \pm 3^{d}\end{array}$ & $\begin{array}{r}9.2 \pm 2 \\
12.3 \pm 1\end{array}$ & $\begin{array}{l}3.7 \pm 3 \\
3.4 \pm 3\end{array}$ & $\begin{array}{c}14.7 \pm 1 \\
5.5 \pm 3^{d} \\
6.8 \pm 2 \\
3.2 \pm 4\end{array}$ & $\begin{array}{l}4.1 \pm 3 \\
1.7 \pm 5\end{array}$ \\
\hline May & $\begin{array}{l}5.6 \pm 2 \\
9.6 \pm 2^{d} \\
5.1 \pm 3 \\
2.4 \pm 3^{d}\end{array}$ & $\begin{array}{l}4.5 \pm 3 \\
2.6 \pm 5 \\
2.6 \pm 6\end{array}$ & $\begin{array}{r}11.2 \pm 2 \\
3.8 \pm 3\end{array}$ & $\begin{array}{l}3.7 \pm 3 \\
2.9 \pm 4\end{array}$ & $\begin{array}{l}7.2 \pm 2 \\
6.5 \pm 3^{d} \\
7.1 \pm 2 \\
7.6 \pm 2^{d}\end{array}$ & $\begin{array}{l}4.8 \pm 3 \\
5.7 \pm 3\end{array}$ \\
\hline June & $\begin{array}{l}4.8 \pm 3 \\
6.6 \pm 3^{d} \\
5.3 \pm 4 \\
3.4 \pm 4^{d}\end{array}$ & $\begin{array}{l}2.3 \pm 5 \\
2.8 \pm 6^{d} \\
2.4 \pm 7 \\
2.2 \pm 6^{d}\end{array}$ & $\begin{array}{l}3.5 \pm 5 \\
-b\end{array}$ & $\begin{array}{l}2.2 \pm 5 \\
2.0 \pm 7\end{array}$ & $\begin{array}{l}6.2 \pm 3 \\
4.2 \pm 4^{d} \\
6.3 \pm 3 \\
5.8 \pm 3^{d}\end{array}$ & $\begin{array}{l}4.0 \pm 3 \\
3.1 \pm 4\end{array}$ \\
\hline Jul. & $\begin{array}{l}3.3 \pm 4 \\
3.5 \pm 5 \\
3.3 \pm 5\end{array}$ & $\begin{array}{l}1.6 \pm 8 \\
1.5 \pm 9 \\
0.6 \pm 19\end{array}$ & $\begin{array}{l}2.6 \pm 4 \\
1.4 \pm 47 \\
0.7 \pm 14\end{array}$ & $\begin{array}{l}1.4 \pm 8 \\
1.1 \pm 10^{d} \\
1.1 \pm 11 \\
0.1 \pm 100 \\
0.4 \pm 26^{d}\end{array}$ & $\begin{array}{l}5.9 \pm 3 \\
4.5 \pm 3 \\
3.1 \pm 5\end{array}$ & $\begin{array}{l}2.0 \pm 6 \\
28 \pm 5 \\
1.4 \pm 8\end{array}$ \\
\hline Aug. & $\begin{array}{l}3.6 \pm 4 \\
4.7 \pm 5\end{array}$ & $\begin{array}{l}1.6 \pm 9 \\
2.5 \pm 6\end{array}$ & $\begin{array}{l}1.5 \pm 7 \\
3.1 \pm 5\end{array}$ & $\begin{array}{l}1.0 \pm 10 \\
1.1 \pm 11^{d} \\
1.7 \pm 8 \\
2.5 \pm 6^{d}\end{array}$ & $\begin{array}{l}4.5 \pm 3 \\
6.9 \pm 3\end{array}$ & $\begin{array}{l}2.9 \pm 4 \\
3.7 \pm 4\end{array}$ \\
\hline Sept. & $\begin{array}{l}8.8 \pm 2 \\
3.0 \pm 5 \\
5.4 \pm 3\end{array}$ & $\begin{array}{l}1.7 \pm 8 \\
1.5 \pm 9 \\
6.7 \pm 3\end{array}$ & $\begin{array}{c}4.4 \pm 4 \\
3.2 \pm 5 \\
3.3 \pm 5^{d} \\
22.9 \pm 1 \\
24.1 \pm 1^{d}\end{array}$ & $\begin{array}{l}-^{b} \\
0.7 \pm 16^{d} \\
1.3 \pm 10 \\
2.9 \pm 4\end{array}$ & $\begin{array}{l}6.2 \pm 2 \\
4.2 \pm 4 \\
4.1 \pm 3\end{array}$ & $\begin{array}{l}3.0 \pm 4 \\
2.0 \pm 7 \\
2.2 \pm 5\end{array}$ \\
\hline Oct. & $\begin{array}{l}4.9 \pm 4 \\
3.2 \pm 5\end{array}$ & $\begin{array}{l}3.8 \pm 4 \\
2.9 \pm 5\end{array}$ & $\begin{array}{l}2.6 \pm 5 \\
4.0 \pm 5 \\
3.7 \pm 5\end{array}$ & $\begin{array}{l}2.1 \pm 8 \\
29 \pm 8\end{array}$ & $\begin{array}{l}4.5 \pm 4 \\
3.1 \pm 5\end{array}$ & $\begin{array}{l}2.1 \pm 6 \\
1.7 \pm 8\end{array}$ \\
\hline Nov. & $\begin{array}{r}10.0 \pm 2 \\
2.3 \pm 5\end{array}$ & $\begin{array}{l}3.2 \pm 5 \\
2.8 \pm 5\end{array}$ & $\begin{array}{l}3.9 \pm 4 \\
4.5 \pm 4\end{array}$ & $\underset{-b}{1.3 \pm 10}$ & $\begin{array}{l}2.1 \pm 8 \\
2.6 \pm 5\end{array}$ & $\begin{array}{l}1.4 \pm 9 \\
1.8 \pm 7 d \\
1.5 \pm 6\end{array}$ \\
\hline
\end{tabular}


Table A-6a. (Continued).

\begin{tabular}{|c|c|c|c|c|c|c|}
\hline \multirow[b]{3}{*}{ Month } & \multicolumn{6}{|c|}{ Sampling location ${ }^{2}$} \\
\hline & 1 & 2 & 12 & 13 & 14 & 15 \\
\hline & \multicolumn{6}{|c|}{$\left[1 \sigma^{-11} \mu \mathrm{Ci} / \mathrm{mL} \pm 2 \sigma(\%)\right]$} \\
\hline \multirow[t]{4}{*}{ Dec. } & $2.2 \pm 6$ & $2.8 \pm 5$ & $3.6 \pm 4$ & $1.9 \pm 6$ & $2.5 \pm 5$ & $1.8 \pm 6$ \\
\hline & $1.5 \pm 5$ & $2.1 \pm 4$ & $6.7 \pm 2$ & $0.8 \pm 9$ & $7.6 \pm 2$ & $3.0 \pm 4^{d}$ \\
\hline & & & & & & $24 \pm 4$ \\
\hline & & & & & & $0.9 \pm 8^{d}$ \\
\hline \multirow[t]{2}{*}{ Average } & 6.6 & 3.2 & 6.9 & 2.1 & 6.8 & 2.7 \\
\hline & $(8.3)^{\mathrm{C}}$ & $(5 . B)^{C}$ & $(9.0)^{\mathrm{C}}$ & $(4.5)^{c}$ & $(10.9)^{c}$ & $(3.5)^{\mathcal{C}}$ \\
\hline \multirow[t]{2}{*}{$\operatorname{SDM}(\mathscr{c})$} & 116 & 53 & 88 & 67 & 83 & 49 \\
\hline & $(140)^{c}$ & $(255)^{c}$ & $(130)^{c}$ & $(272)^{c}$ & $(195)^{c}$ & $(125)^{c}$ \\
\hline Percent of DCG & $3 \times 10^{-2}$ & $2 \times 10^{-2}$ & $3 \times 10^{-2}$ & $1 \times 10^{-2}$ & $3 \times 10^{-2}$ & $1 \times 10^{2}$ \\
\hline Dose $($ mrem) 8 & $7 \times 10^{-2}$ & $5 \times 10^{-2}$ & $7 \times 10^{-2}$ & $4 \times 10^{-2}$ & $9 \times 10^{-2}$ & $3 \times 10^{2}$ \\
\hline
\end{tabular}

a See Fig. 5 for sampling locations.

b No data. See "Deviations from the Monitoring Program" section.

c Outlier. Values with outlier included are in parentheses.

d Quality assurance samples.

E Livermore site perimeter overall average $=4.7 \pm 96(7.0 \pm 81)$.

${ }^{f}$ DCG $=2 \times 10^{-7} \mu \mathrm{Ci} / \mathrm{mL}$ or $2 \times 10^{5} \mathrm{pCi} / \mathrm{m}^{3}$.

$B$ This dose is the effective dose equivalent, and was calculated from the annual average with outlier. 
Table A-6b. Tritium in air-Livermore Valley.

\begin{tabular}{|c|c|c|c|c|c|c|}
\hline \multirow[b]{3}{*}{ Month } & \multicolumn{6}{|c|}{ Sampling locationa } \\
\hline & S-1 & S-2 & V04 & V07 & vos & V17 \\
\hline & & & $\left\{10^{-11} \mu\right.$ & & & \\
\hline \multirow[t]{2}{*}{ Jan. } & $4.7 \pm 3$ & $2.5 \pm 4$ & $-b$ & $5.2 \pm 2$ & $2.8 \pm 4$ & $2.1 \pm 6$ \\
\hline & $1.6 \pm 5$ & $8.0 \pm 2$ & $1.5 \pm 5$ & $-b$ & $1.8 \pm 6$ & $11.2 \pm 2$ \\
\hline \multirow{2}{*}{ Frb. } & $12.2 \pm 2$ & $3.7 \pm 3$ & $18.3 \pm 1^{c}$ & $8.0 \pm 2$ & $3.6 \pm 4$ & $4.0 \pm 3$ \\
\hline & $1.0 \pm 8$ & $2.5 \pm 4$ & $0.6 \pm 11$ & $1.4 \pm 6$ & $-b$ & $-b$ \\
\hline \multirow[t]{2}{*}{ Mar. } & $9.4 \pm 2$ & $24 \pm 5$ & $2.3 \pm 5$ & $55.6 \pm 1^{c}$ & $24 \pm 5$ & $1.3 \pm B$ \\
\hline & $4.1 \pm 3$ & $1.5 \pm 6$ & $1.2 \pm 5$ & $1.5 \pm 6$ & $2.9 \pm 4$ & $0.7 \pm 15$ \\
\hline \multirow[t]{2}{*}{ Apr. } & $3.0 \pm 4$ & $1.6 \pm 6$ & $1.8 \pm 5$ & $3.5 \pm 3$ & $8.4 \pm 2$ & $1.1 \pm 8$ \\
\hline & $1.5 \pm 6$ & $1.9 \pm 5$ & $1.8 \pm 5$ & $1.2 \pm 7$ & $3.6 \pm 3$ & $3.0 \pm 4$ \\
\hline \multirow[t]{2}{*}{ May } & $4.3 \pm 3$ & $2.6 \pm 4$ & $2.4 \pm 6$ & $1.8 \pm 6$ & $4.2 \pm 3$ & $4.3 \pm 3$ \\
\hline & $3.5 \pm 4$ & $3.0 \pm 4$ & $5,4 \pm 3$ & $5.2 \pm 3$ & $2.7 \pm 4$ & $3.1 \pm 4$ \\
\hline \multirow[t]{2}{*}{ jume } & $1.5 \pm 7$ & $0.9 \pm 10$ & $3.3 \pm 4$ & $1.1 \pm 10$ & $2.8 \pm 4$ & $1.7 \pm 7$ \\
\hline & $1.2 \pm 10$ & $0.3 \pm 30$ & $2.1 \pm 6$ & $0.3 \pm 36$ & $1.9 \pm 7$ & $0.7 \pm 13$ \\
\hline \multirow[t]{3}{*}{ Jul. } & $2.1 \pm 6$ & $1.3 \pm 10$ & $2.7 \pm 5$ & $0.9 \pm 13$ & $0.7 \pm 15$ & $0.8 \pm 13$ \\
\hline & $1.3 \pm 9$ & $0.3 \pm 32$ & $2.8 \pm 5$ & $1.2 \pm 11$ & $0.9 \pm 12$ & $0.3 \pm 30$ \\
\hline & $0.9 \pm 13$ & $-b$ & $2.3 \pm 6$ & $0.6 \pm 20$ & $0.8 \pm 16$ & $0.7 \pm 17$ \\
\hline \multirow[t]{2}{*}{ Aug } & $1.9 \pm 7$ & $1.0 \pm 10$ & $3.4 \pm 4$ & $0.6 \pm 16$ & $0.3 \pm 34$ & $0.2 \pm 40$ \\
\hline & $25 \pm 6$ & $5.7 \pm 3$ & $2.3 \pm 6$ & $2.2 \pm 7$ & $1.4 \pm 10$ & $3.4 \pm 5$ \\
\hline \multirow[t]{3}{*}{ Sept. } & $5.7 \pm 3$ & $0.9 \pm 9$ & $4.8 \pm 4$ & $1.1 \pm 11$ & $0.7 \pm 17$ & $0.6 \pm 13$ \\
\hline & $1.4 \pm 9$ & $0.8 \pm 12$ & $0.8 \pm 6$ & $0.7 \pm 16$ & $0.4 \pm 25$ & $0.8 \pm 13$ \\
\hline & $3.0 \pm 4$ & $5.4 \pm 3$ & $3.7 \pm 4$ & $1.0 \pm 10$ & $1.0 \pm 10$ & $0.9 \pm 8$ \\
\hline \multirow[t]{2}{*}{ Oct. } & $2 i \pm 6$ & $3.6 \pm 4$ & $-b$ & $0.2 \pm 36$ & $0.6 \pm 17$ & $1.6 \pm 9$ \\
\hline & $2.5 \pm 6$ & - b & $20 \pm 8$ & $1.1 \pm 19$ & $0.5 \pm 22$ & $0.7 \pm 19$ \\
\hline \multirow[t]{2}{*}{ Nov. } & $4.7 \pm 3$ & $1.6 \pm 7$ & $1.1 \pm 11$ & $1.6 \pm 8$ & $1.5 \pm 10$ & $0.7 \pm 17$ \\
\hline & $1.8 \pm 7$ & $21+6$ & $1.6 \pm 7$ & b & $1.5 \pm 8$ & $1.0 \pm 11$ \\
\hline \multirow[t]{2}{*}{ Dec. } & -b & $13 \pm 9$ & $1.7 \pm 8$ & $0.8 \pm 12$ & - b & $0.8 \pm 13$ \\
\hline & $1.5 \pm 6$ & $1.4 \pm 6$ & b & $0.3 \pm 24$ & $0.3 \pm 24$ & $0.8 \pm 10$ \\
\hline Averagec & 3.2 & 2.3 & $\begin{array}{r}2.3 \\
(3)^{d}\end{array}$ & $\begin{array}{c}1.8 \\
(4)^{d}\end{array}$ & 1.9 & ${ }_{(1.9)^{\mathrm{d}}}^{1.5}$ \\
\hline SDM (\%) & 84 & $: 9$ & $\begin{array}{c}51 \\
(116)^{d}\end{array}$ & $\underset{(280)^{d}}{106}$ & 93 & $\stackrel{81}{(122)^{d}}$ \\
\hline $\begin{array}{l}\text { Percent } \\
\text { of DCGe }\end{array}$ & $2 \times 10^{-2}$ & $1 \times 1 \div-2$ & $1 \times 10^{-2}$ & $1 \times 10^{-2}$ & $1 \times 10^{-2}$ & $6 \times 10^{-3}$ \\
\hline Dose (mrem) $f$ & $3 \times 10^{-2}$ & $2 \times 10^{-2}$ & $2 \times 10^{-2}$ & $3 \times 10^{-2}$ & $2 \times 10^{-2}$ & $2 \times 10^{-2}$ \\
\hline
\end{tabular}

a see Fig. 7 for gampling locations.

b No data. See "Deviations from the Monitoring Program" section.

c Livermore Valley overall average $=2.2 \pm 55(2.7 \pm 62)$.

d Outlier. Values with outlier included are in parentheses.

e $\mathrm{DCG}=2 \times 10^{-7} \mu \mathrm{Ci} / \mathrm{mL}$ or $2 \times 10^{5} \mathrm{pCi} / \mathrm{m} 3$.

This dose is the effective dose equivalent, and was calculated from the annual average with outlier. 
Table A-7. Beryllium on air filters - Livermore site perimeter.

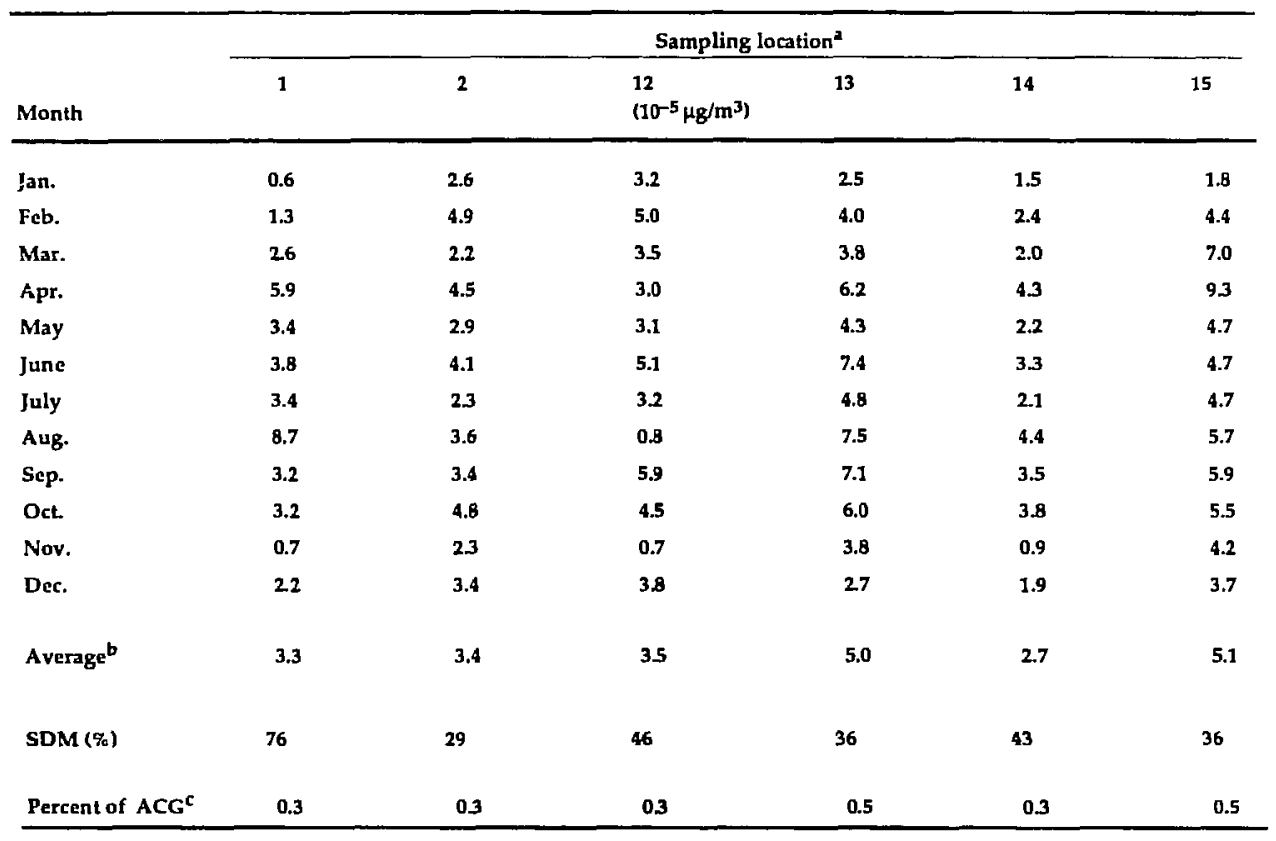

See Fig. 5.

b Livermore site perimeter overall annual average $=3.8 \times 10^{-5} \mu g / \mathrm{m}^{3}$.

${ }^{c}$ Ambient concentration guide set by the Bay Area Air Quality Management District is $0.01 \mu \mathrm{g} / \mathrm{m}^{3}\left(1000 \times 1 \sigma^{-5} \mu \mathrm{g} / \mathrm{m}^{3}\right)$. 
Table A-8. Beryllium on air filters-Site 300.

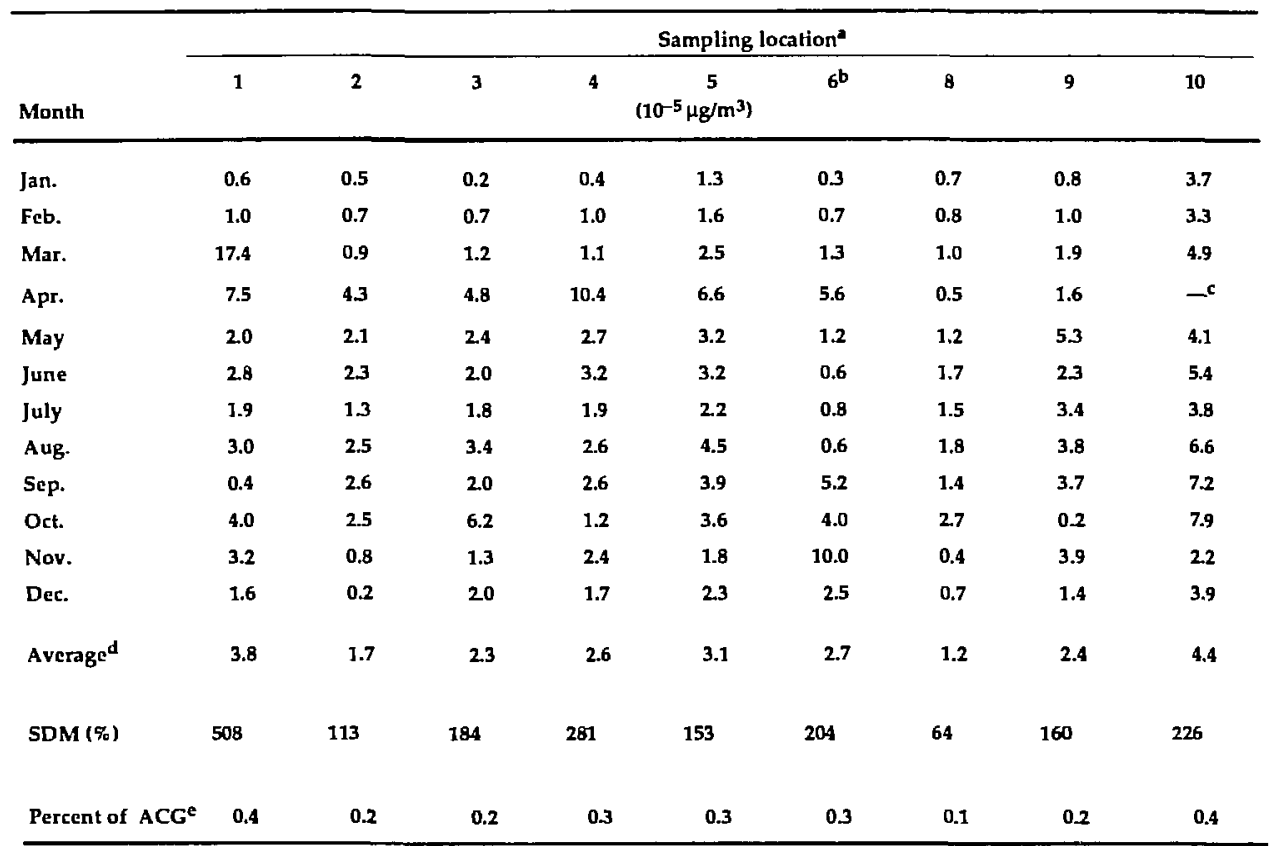

a Sce Fig. 6. for sampling locations.

b Tracy firchouse.

c No data.

d Site 300 overall annual average $=2.7 \times 10^{-5} \mu g^{\prime} \mathrm{m}^{3}$.

e Ambient concentration guide set by the Bay Area Air Quality Management District is $0.01 \mu g^{\prime} \mathrm{m}^{3}\left(1000 \times 10^{-5} \mu g^{/ m^{3}}\right)$. 
Table A-9. Various radionuclides in soil-Livermore Valley (sampling depth $=0$ to $5 \mathrm{~cm}$ ).

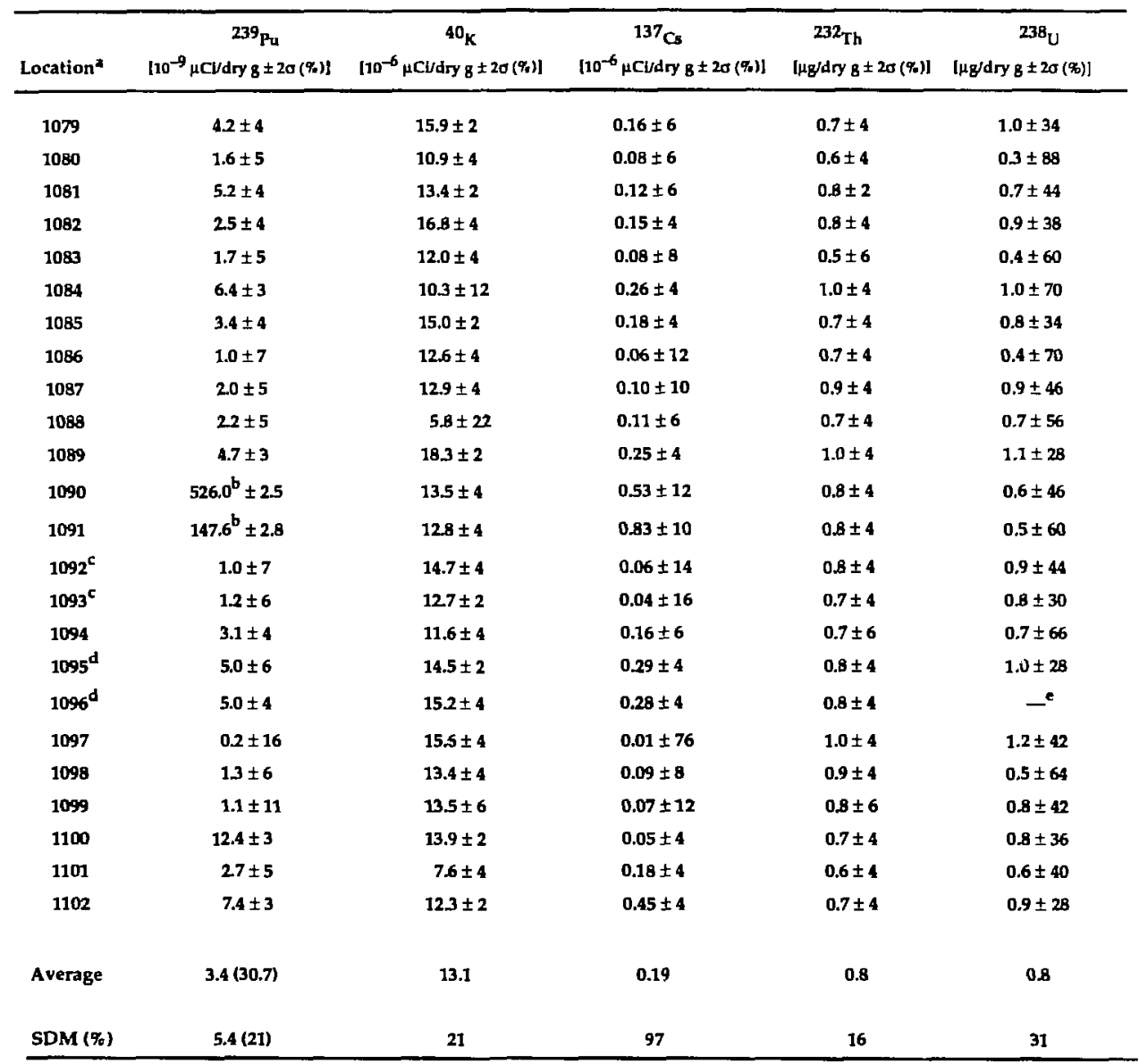

See Fig. 8 for sampling locations.

b Outlier. Data with outlier included are in parentheses.

c Samples 1092 and 1093 are duplicates.

d Samples 1095 and 1096 are duplicates.

Not detected. 
Table A-10. Plutonium, cesium, and uranium in soil-Site 300 (sampling depth $=0$ to $5 \mathrm{~cm}$ ).

\begin{tabular}{|c|c|c|c|c|c|}
\hline Location & $\begin{array}{c}{ }^{239} \mathrm{Pu} \\
{\left[10^{-9} \mu \mathrm{C} \nu / d r y \mathrm{~B} \pm 20(7)\right]}\end{array}$ & $\begin{array}{c}{ }^{40}{ }_{K} \\
{\left[10^{-6} \mu \mathrm{C} / \mathrm{dry} 8 \pm 2 \sigma(q)\right]}\end{array}$ & $\begin{array}{c}{ }^{137} \mathrm{Cs}_{s} \\
{\left[10^{-6} \mu \mathrm{C} / \mathrm{dry} \mathrm{B} \pm 20(9)\right]}\end{array}$ & $\begin{array}{l}{ }^{238} \mathrm{U} \\
\left\lfloor\mathrm{g}_{\mathrm{g}} / \mathrm{dry} \mathrm{B}\right.\end{array}$ & $\begin{array}{c}{ }^{232} \mathrm{Th} \\
\mid \mu \mathrm{g} / \mathrm{d} r \mathrm{~g} \mathrm{~g} \pm 2 \sigma(\%)]\end{array}$ \\
\hline 1103 & $3.6 \pm 5$ & $13.6 \pm 4$ & $0.17 \pm 6$ & $1.0 \pm 66$ & $1.1 \pm 4$ \\
\hline $1104^{b}$ & $6.7 \pm 4$ & $14.8 \pm 4$ & $0.35 \pm 4$ & -c & $0.9 \pm 4$ \\
\hline $1105^{b}$ & $6.6 \pm 4$ & $14.8 \pm 2$ & $0.30 \pm 4$ & $1.4 \pm 32$ & $0.9 \pm 4$ \\
\hline 1106 & $2.8 \pm 5$ & $11.5 \pm 4$ & $0.13 \pm 6$ & $-c$ & $1.0 \pm 4$ \\
\hline 1107 & $2.9 \pm 3$ & $14.5 \pm 4$ & $0.12 \pm 8$ & $2.2 \pm 28$ & $1.5 \pm 4$ \\
\hline 1108 & $4.6 \pm 5$ & $123 \pm 4$ & $0.21 \pm 4$ & $-c$ & $0.8 \pm 4$ \\
\hline $1109^{b}$ & $0.5 \pm 12$ & $10.8 \pm 2$ & $0.03 \pm 22$ & $-^{c}$ & $0.8 \pm 6$ \\
\hline 1110 & $2.9 \pm 4$ & $16.9 \pm 4$ & $0.15 \pm 6$ & $0.3 \pm 92$ & $0.7 \pm 6$ \\
\hline 1111 & $0.3 \pm 12$ & $10.7 \pm 4$ & $0.03 \pm 28$ & $1.0 \pm 28$ & $0.8 \pm 4$ \\
\hline 1112 & $3.3 \pm 4$ & $13.9 \pm 4$ & $0.15 \pm 8$ & $0.6 \pm 66$ & $1.0 \pm 4$ \\
\hline 1113 & $0.6 \pm 9$ & $11.5 \pm 4$ & $0.03 \pm 24$ & $1.9 \pm 20$ & $0.8 \pm 4$ \\
\hline 1114 & $4.9 \pm 4$ & $13.4 \pm 4$ & $0.26 \pm 4$ & $-c$ & $0.9 \pm 4$ \\
\hline 1115 & $4.1 \pm 4$ & $11.6 \pm 6$ & $0.20 \pm 6$ & $149.0 \pm 2^{d}$ & $2.2 \pm 4$ \\
\hline 1116 & $2.4 \pm 5$ & $16.0 \pm 4$ & $0.12 \pm 8$ & $1.2 \pm 46$ & $1.2 \pm 4$ \\
\hline $1117^{b}$ & $0.5 \pm 12$ & $10.1 \pm 4$ & $0.03 \pm 20$ & $0,3 \pm 76$ & $0.6 \pm 6$ \\
\hline Average & 3.1 & 13.1 & 0.15 & $1.1(59)$ & 1.0 \\
\hline $\operatorname{SDM}(\%)$ & 67 & 16 & 66 & $60(294)$ & 39 \\
\hline
\end{tabular}

a See Fig. 9 for sampling locations.

bamples 1104 and 1105 are duplicates; samples 1109 and 1117 are duplicates.

c Not detected.

d Outlier. Values with outlier included are in parentheses. 
Table A-11. Various radionuclides in effluents-LLNL and Livermore Water Reclamation Plant (LWRP).

\begin{tabular}{|c|c|c|c|c|c|c|c|}
\hline \multirow[b]{2}{*}{ Month } & \multicolumn{2}{|c|}{$\begin{array}{c}\text { HTO } \\
{\left[10^{-6} \mu \mathrm{Ci} / \mathrm{mL}_{ \pm 2} 2 \sigma(\%)\right]}\end{array}$} & \multicolumn{2}{|c|}{$\left[110^{-11} \mu \mathrm{Ci} / \mathrm{mL} \pm 2 \sigma\left(\xi_{s}\right)\right]$} & \multicolumn{2}{|c|}{$\begin{array}{c}{ }^{239} \mathrm{Pu} \\
{\left[10^{-12} \mu \mathrm{Ci} / \mathrm{mL} \pm 2 \sigma(\%)\right]}\end{array}$} & \multirow{2}{*}{$\begin{array}{c}\begin{array}{c}209 \\
\text { pu } \\
{\left[1 \sigma^{-8} \mu \mathrm{Ci} i_{g} \pm 2 \sigma(\%)\right]}\end{array} \\
\text { LWRP sludge } \\
\end{array}$} \\
\hline & LLNL & LWRP & LLNL & LWRP & LLNL & LWRP & \\
\hline Jan. & $0.4 \pm 5.7$ & $02 \pm 5.0$ & $72.6 \pm 8$ & $6.1 \pm 50$ & $13.31 \pm 5$ & $0.35 \pm 31$ & \\
\hline Feb. & $1.1 \pm 5.0$ & $0.4 \pm 5.7$ & $171 \pm 4$ & $15.5 \pm 24$ & $2.40 \pm 14$ & $-\infty$ & \\
\hline Mar. & $3.5 \pm 4.6$ & $0.5 \pm 6.0$ & $290^{b} \pm 2$ & $\leq 0.8$ & $6.14 \pm 7$ & $024 \pm 39$ & $7.72 \pm 2$ \\
\hline Apr. & $1.7 \pm 52$ & $02 \pm 6.1$ & $3.3 \pm 76$ & $3.4 \pm 72$ & $1024 \pm 6$ & $0.84 \pm 20$ & \\
\hline May & $6.7 \pm 4.2$ & $0.4 \pm 6.4$ & $14.3 \pm 22$ & $6.5 \pm 44$ & $11100^{b} \pm 2$ & $84.32^{b} \pm 2$ & \\
\hline June & $3.3 \pm 4.5$ & $0.4 \pm 6.0$ & $5.8 \pm 48$ & $\leq 12$ & $236 \pm 2$ & $10.78 \pm 5$ & $1018^{b} \pm 6$ \\
\hline July & $1.3 \pm 5.7$ & $0.4 \pm 6.3$ & $9.1 \pm 28$ & $28 \pm 58$ & $948 \pm 2$ & $3.17 \pm 10$ & \\
\hline Aug & $3.0 \pm 5.3$ & $0.3 \pm 6.4$ & $17.8 \pm 16$ & $\leq 1.0$ & $386 \pm 2$ & $11.32 \pm 6$ & \\
\hline Sept. & $12 \pm 5.7$ & $0.3 \pm 6.7$ & $7.4 \pm 42$ & 50.9 & $518 \pm 2$ & $4.13 \pm 10$ & $270 \pm 2$ \\
\hline Oet. & $0.8 \pm 6.0$ & $0.5 \pm 6.2$ & $8.1 \pm 28$ & $2.8 \pm 80$ & $295 \pm 2$ & $225 \pm 11$ & \\
\hline Nov. & $3.0 \pm 5.6$ & $0.4 \pm 6.1$ & B. $7 \pm 28$ & $3.6 \pm 50$ & $210 \pm 2$ & $3.52 \pm 11$ & \\
\hline Dec. & $1.7 \pm 5.6$ & $12 \pm 5.8$ & $11.6 \pm 18$ & $\leq 1.7$ & $115 \pm 3$ & $2.34 \pm 11$ & $56.15 \pm 2$ \\
\hline Average & 2.3 & 0.4 & $9.6(51.6)$ & $28^{c}$ & 249 (1153) & $9.89(1120)$ & $111(338)$ \\
\hline $\operatorname{SDM}(\%)$ & 75 & 60 & $16(173)$ & $61^{c}$ & $116(273)$ & $102(219)$ & $125(138)$ \\
\hline $\begin{array}{l}\text { DOE } \\
\operatorname{limit} \\
(\mu \mathrm{Ci} / \mathrm{mL})\end{array}$ & $1 \times 10^{-2}$ & $N / A$ & $1.5 \times 10^{-5}$ & $\mathbf{N} / \mathbf{A}$ & $1.0 \times 10^{-5}$ & N/A & N/A \\
\hline $\begin{array}{l}\text { Pereent } \\
\text { of DOE } \\
\text { limit }\end{array}$ & $2 \times 10^{-2}$ & N/A & $\begin{array}{c}6.4 \times 10^{-4} \\
\left(3.1 \times 10^{-3}\right)\end{array}$ & $\mathrm{N} / \mathrm{A}$ & $\begin{array}{l}2.5 \times 10^{-3} \\
\left(12 \times 10^{-2}\right)\end{array}$ & $\mathbf{N} / \mathbf{A}$ & N/A \\
\hline
\end{tabular}

A No data. See the section tilled "Deviations from the Sampling Program."

b Outlier. Data with outlier included are presented in parentheses.

c Median value \pm median absolute deviation. 
Table A-12. Metal discharged to sanitary sewer system: monthly summaries.

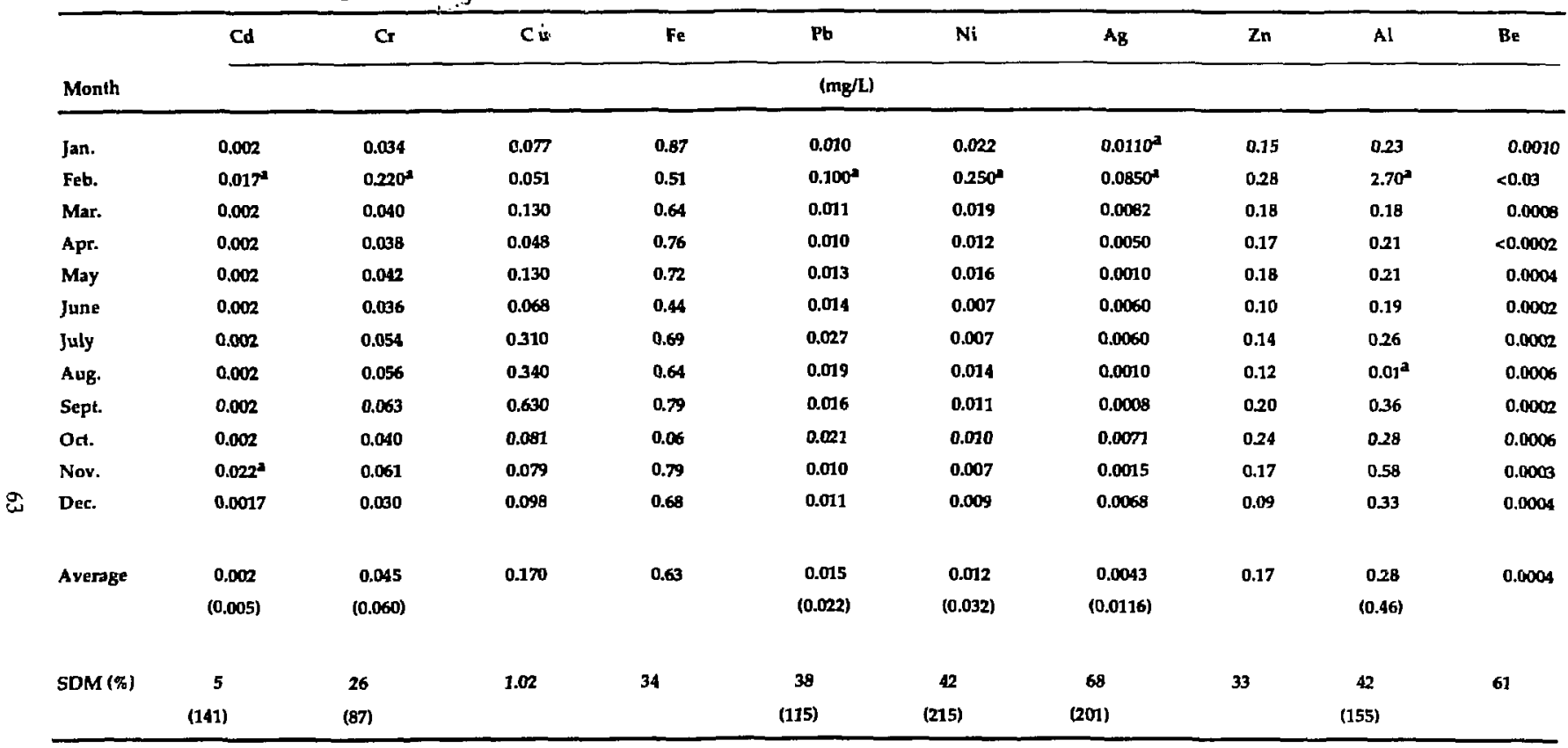

a Outlier. Data with outlier included are presented in parentheses. 
Table A-13. Physical and chemical examinations of LLNL sanitary sewer effluent.

\begin{tabular}{|c|c|c|c|c|c|c|}
\hline & Jan.-Mar. & Apr.-June & July-Sept. & Oct.-Dec. & \multirow[b]{2}{*}{ A verage } & \multirow[b]{2}{*}{$\operatorname{SDM}(\%)$} \\
\hline & \multicolumn{4}{|c|}{ (mg/L) } & & \\
\hline BOD & 63 & 89 & 60 & 75 & 72 & 18 \\
\hline COD & 200 & 210 & 180 & 140 & 182 & 17 \\
\hline Oil and grease & 9 & 48 & 44 & 19 & 30 & 63 \\
\hline Phenolics & $<0.05$ & $<0.35$ & $<0.05$ & 0.19 & 0.16 & 89 \\
\hline $\begin{array}{l}\text { Settleable solids } \\
\text { (mL/Lhr) }\end{array}$ & $-^{2}$ & 8.5 & 1.7 & 18 & 9.4 & 87 \\
\hline Total dissolved solids & 460 & 400 & -2 & 340 & 400 & 15 \\
\hline Total organic carbon & 45 & $\mathbf{3 8}$ & 39 & 60 & 46 & 22 \\
\hline Total solids & 490 & 500 & $-\mathbf{a}$ & 500 & 497 & 1 \\
\hline Total suspended solids & 17 & 30 & -2 & 57 & 35 & 59 \\
\hline $\begin{array}{l}\text { Volatile solids } \\
\text { ( } \% \text { total solids) }\end{array}$ & 56 & $\mathbf{5 7}$ & -2 & 71 & 61 & 14 \\
\hline Ammonia nitrogen (as $N$ ) & 26 & 29 & 31 & 28 & 28 & 7 \\
\hline Chloride & 97 & 85 & 27 & 3 & 53 & 85 \\
\hline Cyanide & $<0,02$ & $<0.02$ & $<0.02$ & $<0.02$ & $<0.02$ & $\mathbf{0}$ \\
\hline Nitrate nitrogen (as N) & $<0.10$ & $<0.01$ & $<0.10$ & $<0.10$ & $<0.08$ & 58 \\
\hline Nitrite nitrogen (as $\mathrm{NO}_{2}$ ) & $<0.03$ & $<0.03$ & $-\mathbf{a}$ & $<0.03$ & $<0.03$ & $\mathbf{0}$ \\
\hline Sulfate & 110 & 86 & 53 & 200 & 112 & 56 \\
\hline Total alkalinity (as $\mathrm{CaCO}_{3}$ ) & 243 & 204 & 126 & -4 & 191 & 31 \\
\hline Total kjeldahl nitrogen (as N) & 21 & 31 & 34 & 33 & 30 & 20 \\
\hline Total phosphorous (as P) & 10 & 3.6 & 13 & 11 & 9.4 & 43 \\
\hline Arsenic & $<0.001$ & 0.003 & $<0.002$ & 0.004 & $<0.002$ & 52 \\
\hline Boron & 0.45 & 0.35 & 0.27 & 0.30 & 0.34 & 23 \\
\hline Calcium & 29 & 18 & 9.2 & 15 & 18 & 47 \\
\hline Chromium & 0.02 & 0.08 & $<0.02$ & 0.19 & 0.08 & 103 \\
\hline Copper & 0.14 & 0.06 & 0.12 & 0.76 & 0.27 & 122 \\
\hline Magnesium & 13 & 10 & 1.3 & 1.6 & 6.5 & 92 \\
\hline Mercury & 0.0003 & 0.0008 & 0.0015 & 0.0013 & 0.0010 & 55 \\
\hline Nickel & $<0.05$ & $<0.05$ & $<0.05$ & $<0.05$ & $<0.05$ & 0 \\
\hline Potassium & 17 & - & 18 & 19 & 18 & 6 \\
\hline Selenium & 0.002 & $<0.001$ & $<0.001$ & $<0.001$ & $<0.001$ & 40 \\
\hline Sodium & $\mathbf{B 1}$ & - & $\mathbf{3 3}$ & 22 & 45 & 69 \\
\hline Sodium (as $\%$ cations) & 42 & $-\mathbf{a}$ & -a & $-“$ & 42 & 0 \\
\hline Zinc 0.20 & 0.13 & 0.17 & 0.50 & 0.25 & 68 & \\
\hline
\end{tabular}

No data.

The following compounds would have been reported had they appeared at or above their respective detection limits as indicated below:

Organochlorine pesticides

$\mu \mathrm{g} /$

Hg/L

Aldrin

0.05

Chlordane

0.3

Endrin

Dieldrin

0.1

0.05

BHC (nixed isomers)

DDT (mixed isomers)

DDE (mixed isomers)

DDD (mixed isomers)

Heptachlor

Heptachlor Epoxide

Methoxychlor

0.05

0.05

0.2

Polychlorinated biphenyls

Aroclors 1016-1262 
Table A-14. Gross alpha activity in water-Livermore Valley.

\begin{tabular}{|c|c|c|c|c|c|}
\hline \multirow[b]{2}{*}{ Location ${ }^{2}$} & \multirow{2}{*}{$\begin{array}{c}\text { Number of } \\
\text { samples }\end{array}$} & Maximum & Minimum & Average & \multirow[b]{2}{*}{$\operatorname{SDM}(\%)$} \\
\hline & & \multicolumn{3}{|c|}{$\left[10^{-9} \mu \mathrm{Ci} / \mathrm{mL} \pm 2 \sigma(\%)\right]$} & \\
\hline 11 & 4 & $\leq 2.8$ & $\leq 2.1$ & $\leq 2.4$ & 12 \\
\hline 15 & 4 & $\leq 3.2$ & $\leq 2.4$ & $\leq 2.7$ & 13 \\
\hline 16 & 4 & $\leq 6.5$ & $\leq 2.5$ & $\leq 4.2$ & 45 \\
\hline 19 & 4 & $\leq 2.8$ & $\leq 2.4$ & $\leq 2.5$ & 7 \\
\hline 20 & 5 & $\leq 4.5$ & $\leq 3.3$ & $\leq 3.7$ & 13 \\
\hline 23 & 4 & $\leq 2.8$ & $\leq 1.7$ & $\leq 2.4$ & 20 \\
\hline 24 & 4 & $\leq 4.8$ & $\leq 1.4$ & $\leq 2.8$ & 52 \\
\hline 26 & 4 & $\leq 2.8$ & $\leq 24$ & $\leq 2.6$ & 7 \\
\hline 29 & 4 & $5.0 \pm 78$ & $\leq 0.6$ & $\leq 27$ & 67 \\
\hline 31 & 3 & $\leq 3.3$ & $\leq 2.4$ & $\leq 2.7$ & 18 \\
\hline 34 & 4 & $\leq 2.8$ & $\leq 1.8$ & $\leq 24$ & 18 \\
\hline 37 & 4 & $\leq 3.3$ & $\leq 0.75$ & $\leq 2.2$ & 48 \\
\hline
\end{tabular}

a See Fig. 10 for sampling locations.

Table A-15. Gross alpha activity in water-Site 300 .

\begin{tabular}{|c|c|c|c|c|c|}
\hline \multirow[b]{2}{*}{ Location ${ }^{2}$} & \multirow{2}{*}{$\begin{array}{l}\text { Number of } \\
\text { samples }\end{array}$} & Maximum & Minimum & Average & \multirow[b]{2}{*}{$\operatorname{SDM}(\%)$} \\
\hline & & \multicolumn{3}{|c|}{$\left[10^{-9} \mu \mathrm{Ci} / \mathrm{mL} \pm 2 \sigma(\%)\right]$} & \\
\hline 1 & 4 & $\leq 3.3$ & $\leq 20$ & 2.6 & 21 \\
\hline 2 & 4 & $\leq 3.3$ & $\leq 20$ & 2.6 & 21 \\
\hline 3 & 4 & $21 \pm 38$ & $\leq \mathbf{2 0}$ & 7.3 & 126 \\
\hline 4 & 4 & $25 \pm 37$ & $\leq \mathbf{2 0}$ & 12.4 & 95 \\
\hline 5 & 4 & $32 \pm 32$ & $\leq 2.0$ & 10.0 & 146 \\
\hline 6 & 4 & $\leq \mathbf{3 3}$ & $\leq \mathbf{2 0}$ & 2.6 & 21 \\
\hline 14 & 4 & $\leq 10$ & $\leq 2.4$ & 4.6 & 78 \\
\hline 20 & 3 & $\leq 3.4$ & $\leq 1.5$ & 2.6 & 38 \\
\hline 21 & 4 & $7.2 \pm 73$ & $\leq 2.8$ & 4.1 & 51 \\
\hline 22 & 4 & $\leq 3.3$ & $\leq 2.0$ & 2.6 & 21 \\
\hline 23 & 3 & $\leq 3.3$ & $\leq 2.4$ & 2.9 & 16 \\
\hline 24 & 4 & $\leq 3.3$ & $\leq 20$ & 2.6 & 21 \\
\hline
\end{tabular}

a See Fig. 11 for sampling locations. 
Table A-16. Gross beta activity in water-Livermore Valley.

\begin{tabular}{|c|c|c|c|c|c|}
\hline \multirow[b]{2}{*}{ Location" } & \multirow{2}{*}{$\begin{array}{l}\text { Number of } \\
\text { samples }\end{array}$} & Maximum & Minimum & Average & \multirow[b]{2}{*}{$\operatorname{SDM}(\%)$} \\
\hline & & & {$\left[10^{-9} \mu \mathrm{Ci} / \mathrm{mL} \pm 2 \sigma\left(\%_{0}\right)\right]$} & & \\
\hline 11 & 4 & $\leq 7.6$ & $\leq 7.4$ & $\leq 7.5$ & 2 \\
\hline 15 & 4 & $\leq 7.6$ & $\leq 2.6$ & $\leq 6.2$ & 39 \\
\hline 16 & 4 & $13 \pm 66$ & $\leq 7.4$ & $\leq 12$ & 27 \\
\hline 19 & 4 & $\leq 7.6$ & $\leq 4.4$ & $\leq 6.7$ & 23 \\
\hline 20 & 5 & $\leq 13$ & $<21$ & $\leq 8.4$ & 47 \\
\hline 23 & 4 & $\leq 7.6$ & $\leq 5.0$ & $\leq 6.8$ & 18 \\
\hline 24 & 4 & $\leq 38$ & $\leq 5.9$ & $\leq 15$ & 106 \\
\hline 26 & 4 & $\leq 7.6$ & $\leq 2.1$ & $\leq 6.1$ & 44 \\
\hline 29 & 4 & $\leq 7.6$ & $\leq 5.4$ & $\leq 7.0$ & 15 \\
\hline 31 & 3 & $\leq 9.2$ & $\leq 7.4$ & $\leq 8.0$ & 13 \\
\hline 34 & 4 & $12 \pm 66$ & $\leq 7.4$ & $\leq 8.6$ & 26 \\
\hline 37 & 4 & $\leq 9.2$ & $\leq 7.4$ & $\leq 8.0$ & 11 \\
\hline
\end{tabular}

" See Fig 10 for sampling locations.

Table A-17. Gross beta activity in water-Site 300 .

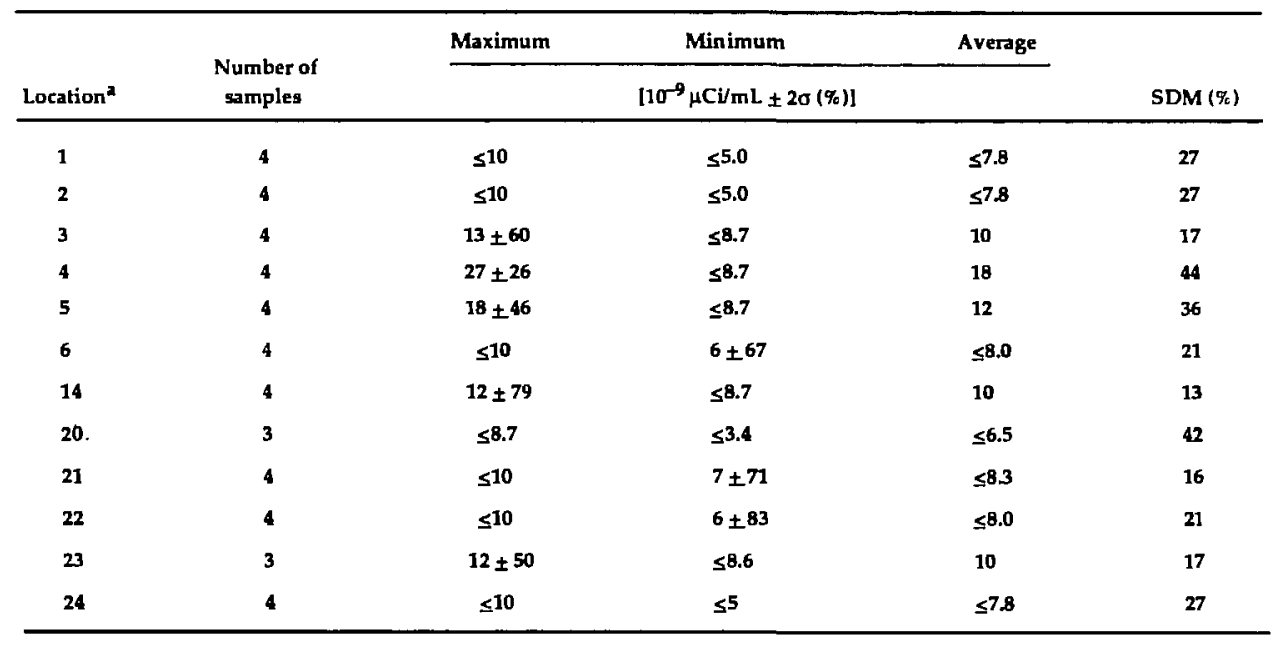

a See Fig. 11 for sampling locationg. 
Table A-18. Various radionuclides in stormwater runoff.

\begin{tabular}{cccc}
\hline Location $^{2}$ & $\begin{array}{c}{ }^{3} \mathrm{H} \\
{\left[10^{-6} \mu \mathrm{Ci} / \mathrm{mL} \pm 2 \sigma(\%)\right]}\end{array}$ & $\begin{array}{c}\text { Gross alpha } \\
\left(1 \sigma^{-9} \mu \mathrm{Ci} / \mathrm{mL}\right)\end{array}$ & $\begin{array}{c}\text { Gross beta } \\
\left(10^{-9} \mu \mathrm{Ci} / \mathrm{mL}\right)\end{array}$ \\
\hline 1 & $1.27 \pm 2.5$ & $\leq 2$ & $\leq 3$ \\
2 & $-\mathrm{b}$ & -6 & -6 \\
3 & $1.51 \pm 2.4$ & $\leq 2$ & $\leq 4$ \\
4 & $-\mathrm{b}$ & $-\mathrm{b}$ & -6 \\
5 & $18.5 \pm 1.6$ & $\leq 2$ & $4 \pm 2$ \\
6 & $2.60 \pm 2.3$ & $\leq 3$ & $4 \pm 2$ \\
\hline
\end{tabular}

a See Fig. 13 for sampling locations.

"No data. See the section titled "Deviations from the Sampiing Program."

Table A-19. Tritium in water-Livermore Valley.

\begin{tabular}{|c|c|c|c|c|c|c|c|c|}
\hline & \multicolumn{8}{|c|}{ Sampling location } \\
\hline & $11^{b}$ & $15^{b}$ & \multicolumn{4}{|c|}{$\left[10^{-7} \mu \mathrm{Ci} / \mathrm{mL} \pm 2 \sigma(\%)\right]$} & $24^{\mathrm{b}}$ & $\mathbf{2 6}^{\mathbf{b}}$ \\
\hline $\begin{array}{l}\text { First } \\
\text { quarter }\end{array}$ & $0.41 \pm 17$ & $0.62 \pm 12$ & $3.13 \pm 4$ & $0.63 \pm 11$ & $\begin{array}{l}36.3 \pm 2 \\
320 \pm 5 \\
17.1 \pm 8\end{array}$ & $0.72 \pm 9$ & $0.91 \pm 8$ & $1.35 \pm 6$ \\
\hline $\begin{array}{l}\text { Seond } \\
\text { quarter }\end{array}$ & $0.52 \pm 12$ & $0.41 \pm 16$ & $233 \pm 4$ & $0.58 \pm 11$ & $1.04 \pm 29$ & $0.34 \pm 17$ & $0.46 \pm 12$ & $1.57 \pm 6$ \\
\hline $\begin{array}{l}\text { Third } \\
\text { quarter }\end{array}$ & $0.42 \pm 15$ & $0.42 \pm 17$ & $1.09 \pm 8$ & $0.78 \pm 9$ & -e & $0.50 \pm 12$ & $0.48 \pm 12$ & $1.68 \pm 5$ \\
\hline $\begin{array}{l}\text { Fourth } \\
\text { quarter }\end{array}$ & $0.49 \pm 12$ & $0.38 \pm 15$ & $1.39 \pm 6$ & $0.32 \pm 17$ & $\begin{array}{r}6.15 \pm 3 \\
10.10 \pm 3 \\
17.40 \pm 2\end{array}$ & $0.42 \pm 13$ & $0.46 \pm 14$ & $1.61 \pm 5$ \\
\hline Average & 0.46 & 0.46 & 1.98 & 0.58 & 17.2 & 0.50 & 0.58 & 1.55 \\
\hline $\operatorname{SDM}(9 a)$ & 12 & 24 & 47 & 33 & 76 & 33 & 38 & 9 \\
\hline $\begin{array}{l}\text { Percent of } \\
\text { DCG }^{f}\end{array}$ & $2 \times 10^{-3}$ & $2 \times 10^{-3}$ & $1 \times 10^{-3}$ & $3 \times 10^{-3}$ & $1 \times 10^{-1}$ & $2 \times 10^{-3}$ & $3 \times 10^{-3}$ & $B \times 10^{-3}$ \\
\hline $\begin{array}{l}\text { Effective } \\
\text { dose (mrem) }\end{array}$ & $2 \times 10^{-3}$ & $2 \times 10^{-3}$ & $9 \times 10^{-3}$ & $3 \times 10^{-3}$ & $9 \times 10^{-2}$ & $2 \times 10^{3}$ & $3 \times 10^{-3}$ & $7 \times 10^{-3}$ \\
\hline
\end{tabular}


Table A-19. (Continued).

\begin{tabular}{|c|c|c|c|c|c|c|c|}
\hline & & & & Sampling location ${ }^{2}$ & & & \\
\hline & $29^{b}$ & $30^{8}$ & $31^{c}$ & {$\left[1 \sigma^{-7} \mu \mathrm{Ci} / \mathrm{mL} \pm 2 \sigma(\%)\right]$} & $34^{h}$ & $37^{c}$ & $43^{i}$ \\
\hline $\begin{array}{l}\text { First } \\
\text { quarter }\end{array}$ & $0.40 \pm 17$ & $0.39 \pm 16$ & $0.49 \pm 14$ & $-\mathbf{e}$ & $0.43 \pm 14$ & $0.48 \pm 14$ & - \\
\hline $\begin{array}{l}\text { Third } \\
\text { quarter }\end{array}$ & $0.61 \pm 12$ & $0.84 \pm 8$ & $0.72 \pm 10$ & -e & $0.61 \pm 11$ & $0.50 \pm 13$ & $\begin{array}{l}9.55 \pm 15 \\
9.47 \pm 15 \\
8.73 \pm 16\end{array}$ \\
\hline Average & 0.46 & 0.50 & 0.46 & - & 0.48 & 0.42 & 9.30 \\
\hline $\operatorname{SDM}(\%)$ & 24 & 46 & 41 & - & 19 & 19 & 37 \\
\hline $\begin{array}{l}\text { Percent of } \\
\text { DCG }\end{array}$ & $2 \times 10^{-3}$ & $2 \times 10^{-3}$ & $2 \times 10^{-3}$ & - & $2 \times 10^{-3}$ & $2 \times 10^{-3}$ & $5 \times 10^{-2}$ \\
\hline $\begin{array}{l}\text { Effective } \\
\text { dose (mrem) }\end{array}$ & $2 \times 10^{-3}$ & $2 \times 10^{-3}$ & $2 \times 10^{-3}$ & - & $2 \times 10^{-3}$ & $2 \times 10^{-3}$ & $4 \times 10^{-2}$ \\
\hline
\end{tabular}

See Fig 10 for sampling locations.

b Surface water.

cTap water-Livermore locations.

d Rain water.

c No data. See "Deviations from the Sampling Program" section.

I $\mathrm{DCG}=2 \times 10^{-3} \mu \mathrm{Ci} / \mathrm{mL}$.

8 Tap water-LLNL.

h Well water.

' LLNL swimming pool. 
Table A-20. Tritium in water-Site $\mathbf{3 0 0 .}$

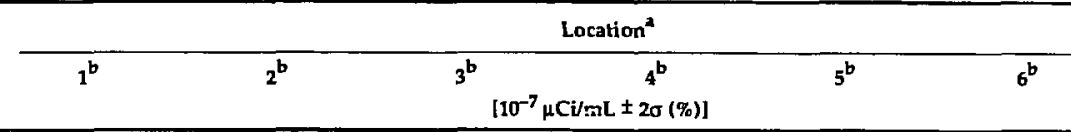

\begin{tabular}{lcccccc}
\hline $\begin{array}{l}\text { First } \\
\text { Cquarter }\end{array}$ & $0.20 \pm 30$ & $0.30 \pm 21$ & $0.05 \pm 94$ & $0.13 \pm 42$ & $0.13 \pm 40$ & $0.10 \pm 54$ \\
$\begin{array}{l}\text { Second } \\
\text { quarter }\end{array}$ & $11.4 \pm 2$ & $0.27 \pm 24$ & 50.04 & $\leq 0.04$ & $0.20 \pm 28$ & $0.05 \pm 99$ \\
$\begin{array}{l}\text { Third } \\
\text { quarter }\end{array}$ & $13.8 \pm 3$ & $1.55 \pm 5$ & $0.24 \pm 23$ & $1.03 \pm 7$ & $0.26 \pm 21$ & $0.1 \pm 40$ \\
$\begin{array}{l}\text { Fourth } \\
\text { quarter }\end{array}$ & $14.7 \pm 3$ & $0.54 \pm 13$ & 50.06 & $0.17 \pm 34$ & $0.20 \pm 31$ & 50.03 \\
$\begin{array}{l}\text { Average } \\
\text { SDM(5) }\end{array}$ & 10 & 0.66 & 0.10 & 0.34 & 0.20 & 0.08 \\
$\begin{array}{l}\text { Percent } \\
\begin{array}{l}\text { Cquarter } \\
\text { of DCG }\end{array}\end{array}$ & $5 \times 10^{-2}$ & $3 \times 10^{-3}$ & $5 \times 10^{-4}$ & $2 \times 10^{-3}$ & $1 \times 10^{-3}$ & $4 \times 10^{-}$ \\
$\begin{array}{l}\text { Effective } \\
\text { Cquarter } \\
\text { dose (mrem) }\end{array}$ & $5 \times 10^{-2}$ & $3 \times 10^{-3}$ & $5 \times 10^{-4}$ & $2 \times 10^{-3}$ & $9 \times 10^{-4}$ & $4 \times 10^{-4}$
\end{tabular}


Table A-20. (Continued).

\begin{tabular}{|c|c|c|c|c|c|c|}
\hline & \multicolumn{6}{|c|}{ Location ${ }^{a}$} \\
\hline & $14^{\mathrm{d}}$ & $20^{6}$ & $21^{d}$ & $22^{b}$ & $23^{b}$ & $24^{b}$ \\
\hline & \multicolumn{6}{|c|}{$\left[10^{-7} \mu \mathrm{Ci} / \mathrm{mL} \pm 2 \sigma\left(F_{0}\right)\right]$} \\
\hline $\begin{array}{l}\text { First } \\
\text { quarter }\end{array}$ & $0.96 \pm 9$ & $\begin{array}{l}0.61 \pm 11 \\
0.66 \pm 10 \\
0.42 \pm 17\end{array}$ & $0.55 \pm 14$ & $0.32 \pm 20$ & $0.29 \pm 26$ & $0.17 \pm 40$ \\
\hline $\begin{array}{l}\text { Second } \\
\text { quarter }\end{array}$ & $0.46 \pm 12$ & $-f$ & $0.11 \pm 53$ & $\leq 0.05$ & $\leq 0.06$ & $0.07 \pm 67$ \\
\hline $\begin{array}{l}\text { Third } \\
\text { quarter }\end{array}$ & $1.01 \pm 7$ & $-\mathbf{f}$ & $0.22 \pm 29$ & $0.12 \pm 41$ & $0.08 \pm 60$ & $\leq 0.05$ \\
\hline Average & 0.71 & 0.51 & 0.30 & 0.13 & 0.12 & 0.09 \\
\hline $\operatorname{SDM}(\%)$ & 44 & 20 & 62 & 106 & 91 & 64 \\
\hline $\begin{array}{l}\text { Percent } \\
\text { of DCG }\end{array}$ & $4 \times 10^{-3}$ & $2 \times 10^{-3}$ & $2 \times 10^{-3}$ & $6 \times 10^{-1}$ & $6 \times 10^{-4}$ & $4 \times 10^{-4}$ \\
\hline $\begin{array}{l}\text { Effective } \\
\text { dose (mrem) }\end{array}$ & $3 \times 10^{-3}$ & $2 \times 10^{-3}$ & $2 \times 10^{-3}$ & $6 \times 10^{-4}$ & $6 \times 10^{-4}$ & $4 \times 10^{-4}$ \\
\hline
\end{tabular}

See Fig. 11 for sampling locations.

b Well water.

${ }^{c} \mathrm{DCG}=2 \times 10^{-3} \mu \mathrm{Ci} / \mathrm{mL}$.

d Surface water.

Rain water.

I No data available. See the section titled "Deviations from the Sampling Program." 
Table A-21. Water-quality parameters in ground and surface waters in the vicinity of Site 300.

\begin{tabular}{|c|c|c|c|c|c|c|c|c|c|}
\hline \multirow[b]{2}{*}{ Location ${ }^{b}$} & \multicolumn{6}{|c|}{ Nonradiological analyted (mg/L) } & \multicolumn{3}{|c|}{ Radiulogical analyte $\left(10^{-9} \mu \mathrm{Ci} / \mathrm{mL}\right\}$} \\
\hline & Arsenic & Barium & Lead & Selenium & Fluoride & Nitrate (as N) & $\begin{array}{l}\text { Gross } \\
\text { alpha }\end{array}$ & $\begin{array}{c}\text { Gross } \\
\text { beta }\end{array}$ & Tritium \\
\hline V-1 (NW) & 0.004 & $<0.1$ & 0.001 & $<0.001$ & 0.57 & $<0.44$ & $<10$ & 13 & $<312$ \\
\hline V-2 (NW) & $<0.001$ & $<0.1$ & 0.004 & 0.001 & 0.60 & 28 & $<2$ & $<3$ & $<265$ \\
\hline$V-3(W)$ & $<0.001$ & 0.1 & $<0.001$ & 0.004 & 0.93 & 47 & $<4$ & $<3$ & $<254$ \\
\hline$V A(W)$ & $<0.001$ & $<0.1$ & 0.004 & 0.001 & 0.55 & 38 & $<3$ & 7 & $<280$ \\
\hline$V_{-6}(\mathrm{NE})$ & $<0.001$ & $<0.1$ & 0.024 & 0.002 & 0.21 & 65 & $<3$ & 6 & 294 \\
\hline V-7 (E) & 0.015 & $<0.1$ & 0.010 & 0.003 & 0.54 & 34 & $<3$ & 14 & $<329$ \\
\hline$V-8(E)$ & 0.013 & $<0.1$ & 0.012 & 0.005 & 0.59 & 26 & $<5$ & 10 & $<250$ \\
\hline P-1 (E) & 0.003 & $<0.1$ & 0.015 & $<0.001$ & 0.47 & $<0.44$ & $<6$ & $<4$ & $<205$ \\
\hline$C-1(S)$ & 0.001 & $<0.1$ & $<0.001$ & $<0.001$ & 0.65 & 0.66 & $<3$ & $<4$ & $<239$ \\
\hline$C-3(S)$ & $<0.001$ & $<0.1$ & 0.019 & $<0.001$ & 0.28 & 0.44 & $<5$ & 11 & $<258$ \\
\hline$F-1$ (SE) & 0.001 & $<0.1$ & 0.011 & $<0.001$ & 0.34 & 3.3 & $<3$ & 10 & $<625$ \\
\hline G-1 (S) & $<0.001$ & $<0.1$ & 0.001 & 0.001 & 0.31 & 2.0 & $<5$ & 9 & $<205$ \\
\hline G-2 (S) & 0.015 & $<0.1$ & $<0.001$ & 0.001 & 1.1 & $<0.44$ & $<2$ & 14 & $<244$ \\
\hline$G-4$ (S) & 0.004 & $<0.1$ & 0.14 & 0.001 & 0.74 & 0.49 & $<2$ & 13 & $<205$ \\
\hline G-5 (S) & $<0.001$ & $<0.1$ & 0.004 & 0.001 & 0.71 & 15 & $<3$ & $<5$ & $<205$ \\
\hline M-1A (N) & $<0.001$ & $<0.1$ & 0.013 & $<0.001$ & 0.71 & 8.9 & 3 & 9 & $<205$ \\
\hline $\mathrm{M}-2 \mathrm{~A}(\mathrm{~N})$ & 0.004 & $<0.1$ & $<0.001$ & $<0.001$ & 0.87 & $<0.44$ & $<5$ & 34 & $<266$ \\
\hline $\mathrm{M}-3 A(N)$ & $<0.001$ & $<0.1$ & 0.015 & 0.001 & 0.60 & 12 & $<4$ & $<7$ & $<205$ \\
\hline$M-6 A(N W)$ & 0.009 & $<0.1$ & 0.012 & 0.002 & 0.58 & 34 & $<5$ & 7 & $<377$ \\
\hline$W-1(W)$ & 0.003 & $<0.1$ & 0.003 & 0.005 & 0.50 & 60 & $<5$ & 28 & $<350$ \\
\hline $\mathbf{W}-\mathbf{2}(\mathbf{W})$ & $<0.001$ & $<0.1$ & 0.001 & $<0.001$ & 0.31 & 125 . & 16 & 63 & $<320$ \\
\hline$W-3(W)$ & 0.005 & $<0.1$ & 0.003 & $<0.001$ & 0.32 & $<0.44$ & $<7$ & 17 & $<229$ \\
\hline
\end{tabular}

a Concentrations of cadmium, chromium, mercury, silver, beryllium, and organic primary drinking water standard analytes were below the analytical level of detection for all sampling locations.

b Compass direction from the center of Site 300 is in parentheses. 
Table A-22. Tritium in groundwater-Livermore Valley.

\begin{tabular}{|c|c|c|}
\hline $\begin{array}{l}\text { Well } \\
\text { identification }\end{array}$ & $\begin{array}{c}\text { Activity } \\
{\left[10^{-7} \mu \mathrm{Ci} / m \mathrm{~mL} \pm 2 \sigma(\%)\right]}\end{array}$ & Pereent if $\mathrm{DCG}^{\mathrm{b}}$ \\
\hline 3S1E-1H3 & $0.1 \pm 52$ & $5 \times 10^{-4}$ \\
\hline 3S1E-1P2 & $3.1 \pm 4$ & $2 \times 10^{2}$ \\
\hline 3S1E-1R2 & $0.7 \pm 10$ & $4 \times 10^{-3}$ \\
\hline 3S1E-2R1 & $2.3 \pm 4$ & $1 \times 10^{-2}$ \\
\hline 351E-9M2 & $0.8 \pm 9$ & $4 \times 10^{-3}$ \\
\hline 351E-11B1 & $8.2 \pm 3$ & $4 \times 10^{-2}$ \\
\hline $3 \mathrm{~S} 1 \mathrm{E}-12 \mathrm{~A} 2$ & $1.2 \pm 7$ & $6 \times 10^{-3}$ \\
\hline 3S1E-12D2 & $5.5 \pm 3$ & $3 \times 10^{-2}$ \\
\hline 3S1E-12G1 & $2.7 \pm 4$ & $1 \times 10^{-2}$ \\
\hline 3S1E-16L5 & $0.6 \pm 10$ & $3: 10^{-3}$ \\
\hline 3S1E-17D2 & $\leq 0.1$ & $\leq 5 \times 10^{-4}$ \\
\hline 3S1E-18A5 & $0.2 \pm 30$ & $1 \times 10^{-3}$ \\
\hline 3S2E-7C2 & $1.2 \pm 7$ & $6 \times 10^{-3}$ \\
\hline 3S2E-7P3 & $0.1 \pm 53$ & $5 \times 10^{-4}$ \\
\hline 352E-16B1 & $0.2 \pm 22$ & $1 \times 10^{-3}$ \\
\hline
\end{tabular}

See Fig. 12 for sampling locations.

${ }^{b} \mathrm{DCG}=2 \times 10^{-3} \mu \mathrm{Ci} / \mathrm{mL}$. 
Table A-23. LLNL stormwater runoff-nonradioactive parameters.

Sampling location ${ }^{2}$

Positively detected parameters

\begin{tabular}{llllll}
\multicolumn{8}{c}{} & Sampling location & \\
1 & 2 & 3 & 4 & 5 & 6
\end{tabular}

Physical (mg/L)

\begin{tabular}{|c|c|c|c|c|c|c|}
\hline Nitrate (as N) & 1.3 & $-\mathbf{b}$ & 0.82 & $-b$ & 0.83 & 0.17 \\
\hline COD & 8 & $-\mathbf{b}$ & $<5$ & - b & $<5$ & $<5$ \\
\hline Oil and grease & 10 & $-b$ & 7 & $-b$ & 12 & $<5$ \\
\hline Cadmium & 0.0007 & $-b$ & $<0.0001$ & $-\mathbf{b}$ & $<0,0001$ & $<0.0001$ \\
\hline Chromium & 0.0014 & $-\mathbf{b}$ & $<0.0015$ & $-\mathbf{b}$ & 0.0016 & 0.0007 \\
\hline Lead & 0.003 & $-b$ & $<0.001$ & $-b$ & $<0.001$ & 0.002 \\
\hline Mercury & $<0.0001$ & $-b$ & 0.0002 & $-\mathbf{b}$ & 0.0002 & 0.0002 \\
\hline Silver & 0.0001 & -b & $<0.0001$ & $-^{\mathbf{b}}$ & $<0.0001$ & $<0.0001$ \\
\hline
\end{tabular}

Organics (mg/L)

TOC

9.0

- b

7.9

$-\mathbf{b}$

8.0

6.2

See Fig. 13 for sampling locations.

b No data. See the section titled "Deviations from the Sampling Program."

The following organic compounds would have been reported had they appeared above the detection limits indicated below:

Title 22 organics (mg/L)

2,4,5-TP (Silvex)

2,4-0

Endrin

Lindane

Methoxychlor

Toxaphene

\section{Purgeable priority pollutants (EPA 624) $(\mu \mathrm{g} / \mathrm{L})$}

0.2

1.0

0.1

0.05

0.2

1.0
Acrolein

10

Acrylonitrile

10

All other analytes 
Table A-24. Tritium in vegetation-Livermore Valley.

\begin{tabular}{|c|c|c|c|c|c|c|c|c|}
\hline & \multicolumn{8}{|c|}{ Sampling locationa } \\
\hline & 4 & 15 & 20 & 23 & & 31 & 32 & 33 \\
\hline & \multicolumn{8}{|c|}{$\left[10^{-7} \mu \mathrm{Ci} / \mathrm{mL}\right.$ of moisture content $\left.\pm 2 \sigma(\%)\right]$} \\
\hline $\begin{array}{l}\text { First } \\
\text { quarter }\end{array}$ & $3.4 \pm 33$ & $48.6 \pm 3$ & $33.3 \pm 4$ & $\begin{array}{l}85.5 \pm 2 \\
65.9 \pm 3\end{array}$ & $46.2 \pm 4$ & $11.4 \pm 11$ & $2.7 \pm 41$ & $4.6 \pm 25$ \\
\hline $\begin{array}{l}\text { Second } \\
\text { quarter }\end{array}$ & $5.2 \pm 22$ & $25.0 \pm 6$ & $5.1 \pm 23$ & $16.8 \pm 8$ & $14.3 \pm 9$ & $7.8 \pm 15$ & $3.9 \pm 29$ & $2.2 \pm 51$ \\
\hline $\begin{array}{l}\text { Third } \\
\text { quarter }\end{array}$ & $3.7 \pm 33$ & $9.9 \pm 14$ & $1.5 \pm 81$ & $26.5 \pm 6$ & $10.3 \pm 13$ & $10.5 \pm 13$ & $\leq 1.2$ & $\leq 1.2$ \\
\hline $\begin{array}{l}\text { Fourth } \\
\text { quarter }\end{array}$ & $19.5 \pm 8$ & $-\mathbf{b}$ & $9.9 \pm 14$ & $-\mathbf{b}$ & $22.4 \pm 7$ & $16.5 \pm 9$ & $7.9 \pm 17$ & $\leq 1.2$ \\
\hline Average & 8.0 & 37.4 & 12.4 & 42.9 & 21.6 & 11.1 & 4.6 & 2.3 \\
\hline $\operatorname{SDM}\left({ }^{\circ}\right)$ & 97 & 66 & 115 & 87 & 67 & 30 & 63 & 70 \\
\hline $\begin{array}{l}\text { Elfective } \\
\text { doge (mrem) }\end{array}$ & $1 \times 10^{-2}$ & $7 \times 10^{-2}$ & $2 \times 10^{-2}$ & $8 \times 10^{-2}$ & $4 \times 10^{-2}$ & $2 \times 10^{-2}$ & $8 \times 10^{-3}$ & $4 \times 10^{-3}$ \\
\hline
\end{tabular}

a See Fig. 14 for aampling locations.

b No data. See "Deviations from the Sampling Program" section.

CThis dose represents the total effective dose from the forage-cow-milk pathway.

Table A-25. Tritium in vegetation-Site 300.

\begin{tabular}{|c|c|c|c|c|c|c|}
\hline & \multicolumn{6}{|c|}{ Sampling location" } \\
\hline & 1 & 2 & 3 & 6 & 12 & 13 \\
\hline & \multicolumn{6}{|c|}{$\left[10^{-7} \mu \mathrm{Ci} / \mathrm{mL}\right.$ of moisture content $\left.\pm 2 \sigma(\%)\right]$} \\
\hline $\begin{array}{l}\text { First } \\
\text { quarter }\end{array}$ & $\begin{array}{l}1.8 \pm 60 \\
2.7 \pm 42\end{array}$ & $1.8 \pm 62$ & $27 \pm 42$ & $10.5 \pm 12$ & $2.0 \pm 54$ & $284 \pm 1$ \\
\hline $\begin{array}{l}\text { Second } \\
\text { quarter }\end{array}$ & $\leq 1.1$ & $1.2 \pm 92$ & $\leq 1.1$ & $10.6 \pm 12$ & $22 \pm 50$ & $\begin{array}{l}33.6 \pm 5 \\
107 \pm 2\end{array}$ \\
\hline $\begin{array}{l}\text { Third } \\
\text { quarter }\end{array}$ & $\begin{array}{l}\leq 1.2 \\
\leq 1.2\end{array}$ & $1.6 \pm 75$ & $\leq 1.2$ & $91.8 \pm 3$ & $1.4 \pm 86$ & $1.7 \pm 70$ \\
\hline $\begin{array}{l}\text { Fourth } \\
\text { quarter }\end{array}$ & $\leq 1.2$ & $\begin{array}{l}\leq 1.2 \\
\leq 1.3^{b}\end{array}$ & $\leq 1.2$ & $6.6 \pm 20$ & $4.6 \pm 28$ & $390 \pm 1$ \\
\hline A verage & $12^{c}$ & $1.3^{\mathrm{C}}$ & $1.2^{\mathrm{C}}$ & 29.9 & 2.6 & 163.3 \\
\hline $\operatorname{SDM}(\%)$ & $4^{d}$ & $8^{d}$ & $4^{d}$ & 138 & 55 & 102 \\
\hline $\begin{array}{l}\text { Effective } \\
\text { dose (mrem) }\end{array}$ & $2 \times 10^{-3}$ & $2 \times 10^{-3}$ & $2 \times 10^{-3}$ & $5 \times 10^{-2}$ & $5 \times 10^{-3}$ & $3 \times 10^{-1}$ \\
\hline
\end{tabular}

See Fig. 15 for sampling locations.

Q Quality assurance duplicate sample.

CMedian value. See Appendix $B$.

Median absolute deviation (\%). See Appendix B.

e This dose represents the total effective dose equivalent from the forage-cow-milk pathway. 
Table A-26. Tritium in wine.

\begin{tabular}{cccc}
\hline & & Sampling location & European \\
wample & $\begin{array}{c}\text { Livermore } \\
\text { wines }\end{array}$ & $\begin{array}{c}\text { Other Californian wines } \\
{\left[10^{-7} \mu \mathrm{Ci} / \mathrm{mL} \pm 2 \sigma(\%)\right]}\end{array}$ & $5.26 \pm 17$ \\
1 & $2.83 \pm 30$ & $1.11 \pm 74$ & $2.89 \pm 29$ \\
2 & $5.18 \pm 17$ & $1.51 \pm 55$ & $2.90 \pm 29$ \\
3 & $2.93 \pm 27$ & $1.44 \pm 55$ & 3.68 \\
Average & $7.41 \pm 12$ & 1.35 & 37 \\
SDM & 4.59 & 16 & \\
\hline
\end{tabular}

Table A-27. Tritium in honey

\begin{tabular}{lcc}
\hline & \multicolumn{1}{c}{ Sampling location $\left[10^{-7} \mu \mathrm{Ci} / \mathrm{mL}\right.$ (in water recovered $\left.\pm 2 \sigma(\%)\right]$} & California \\
\cline { 2 - 3 } 1 & Livermore & $1.46 \pm 30$ \\
2 & $1.14 \pm 19$ & $1.36 \pm 17$ \\
Average & $1.90 \pm 12$ & 1.41 \\
SDM $(q)$ & 1.52 & 5 \\
\hline
\end{tabular}


Table A-28a. Tritium in milk-Livermore Valley.

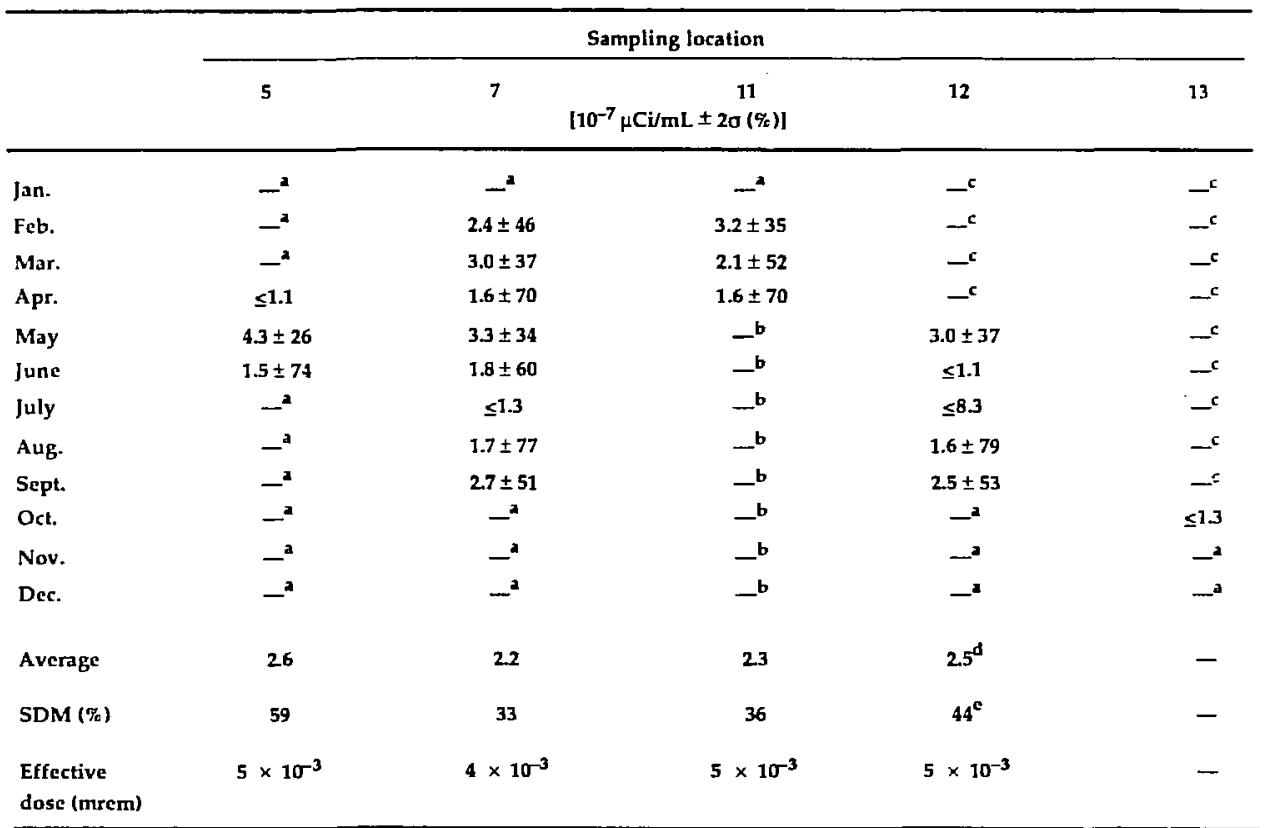

"No data. See "Deviationg from the Sampling Program" section.

b No data; location dropped. See "Chinges to the Environmental Monitoring Program" section.

"New location. See "Changes to the Environmental Monitoring Program" section.

d Median value. Sec Appendix B.

'Meciian absolute deviation (\%). See Appendix B. 
Table A-28b. Potassium-40 in milk-Livermore Valley.

\begin{tabular}{|c|c|c|c|c|c|}
\hline & & & Sampling locatic & & \\
\hline & 5 & 7 & $\begin{array}{c}11 \\
{\left[10^{6} \mu \mathrm{Ci} / \mathrm{mL} \pm 2 \sigma(\%)\right]}\end{array}$ & 12 & 13 \\
\hline Jan. & $-^{\mathbf{b}}$ & $\boldsymbol{-}^{\mathbf{b}}$ & $-b$ & $-^{d}$ & -d \\
\hline Feb. & $-\mathbf{b}$ & 1.4 & 1.4 & $-d$ & -d \\
\hline Mar. & $-\mathbf{b}$ & 1.6 & 1.5 & $-^{d}$ & $-{ }^{d}$ \\
\hline Apr. & 2.4 & 1.5 & 1.9 & $-d$ & - d \\
\hline May & 2.8 & 1.8 & $--^{c}$ & 1.9 & $-d$ \\
\hline hene & 1.9 & 2.1 & $-c$ & 1.9 & $-d$ \\
\hline July & $-\mathbf{b}$ & 2.1 & $-c$ & 2.0 & -d \\
\hline Aug & $-b$ & 1.8 & $-^{c}$ & 1.9 & $-{ }^{d}$ \\
\hline Sept. & $-\mathbf{b}$ & 2.0 & $-c$ & 2.0 & $-{ }^{\mathbf{d}}$ \\
\hline Oct. & $-\mathbf{b}$ & - & $-^{c}$ & $-\mathbf{b}$ & 1.8 \\
\hline Nov. & $-b$ & $-b$ & $-{ }^{c}$ & $-b$ & $-\mathbf{b}$ \\
\hline Dec. & $-^{b}$ & $-\mathbf{b}$ & $-^{c}$ & $-\mathbf{b}$ & $-^{b}$ \\
\hline Average & 2.4 & 1.8 & 1.6 & 1.9 & - \\
\hline $\operatorname{SDM}(\xi)$ & 19 & 15 & 16 & 3 & - \\
\hline
\end{tabular}

${ }^{2}$ Potassium- 40 is a naturally occurring radionuclide and is not an emission from LLNL

b No data; see the section titled "Deviations from the Sampling Program."

"No data; location dropped. Sce the section titled "Changes to the Environmental Monitoring Program."

¿New location. See the section titled "Changes to the Enjironmental Monitoring Program." 
Table A-28c. Cesium-137 in milk-Livermore Valley.

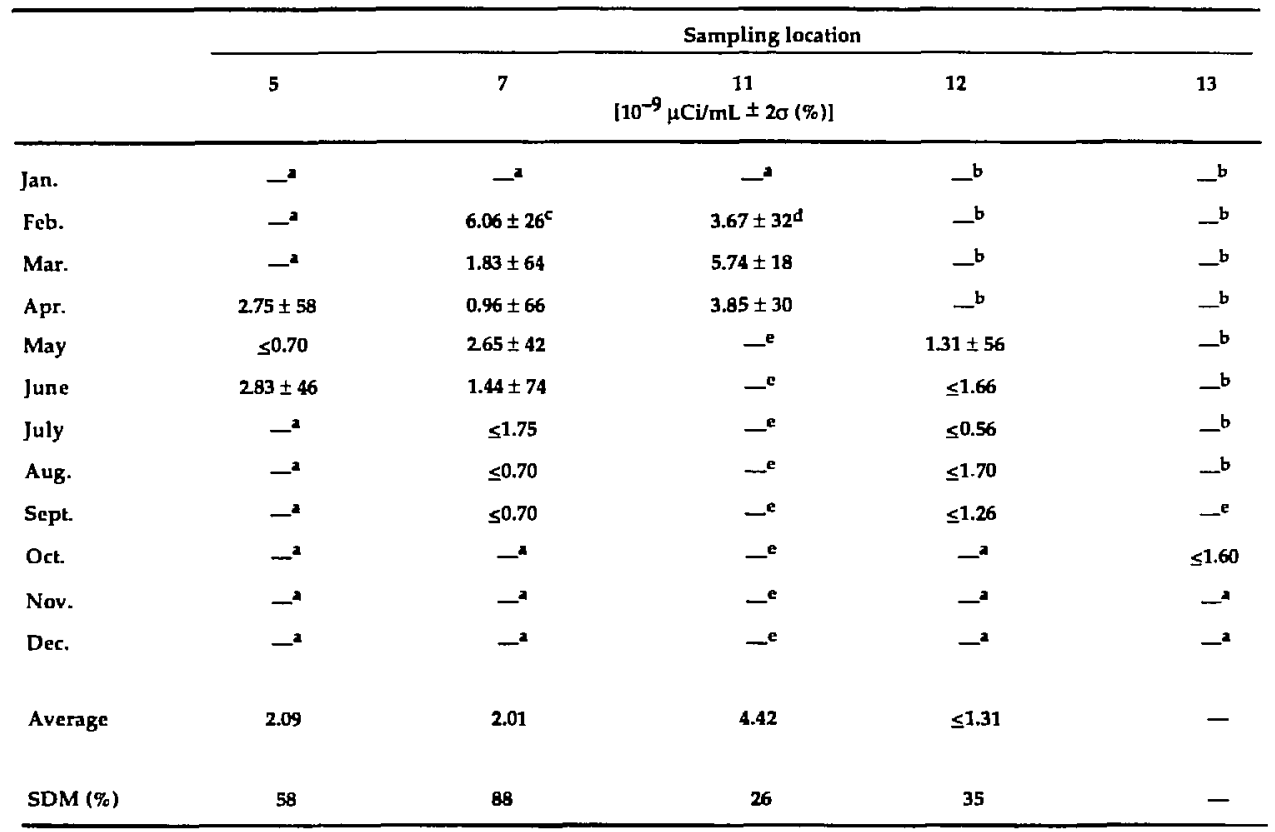

a No data. See "Deviations from the Sampling Program" section.

b This month ${ }^{334} \mathrm{Cs}$ was also detected at a level of $4.41 \pm 38 \% 10^{-9} \mu \mathrm{Ci} / \mathrm{mL}$.

cNew location. See "Changes to the Environmental Monitoring Program" section.

d This month ${ }^{134} \mathrm{Cs}$ was also detected at a level of $1.30 \pm 60 \% 10^{-9} \mu \mathrm{Ci} / \mathrm{mL}$.

"No data; location dropped. See "Changes to the Environmental Monitoring Program" section. 
Table A-29. Environmental radiation measurements (TLD)-Livermore site perimeter.

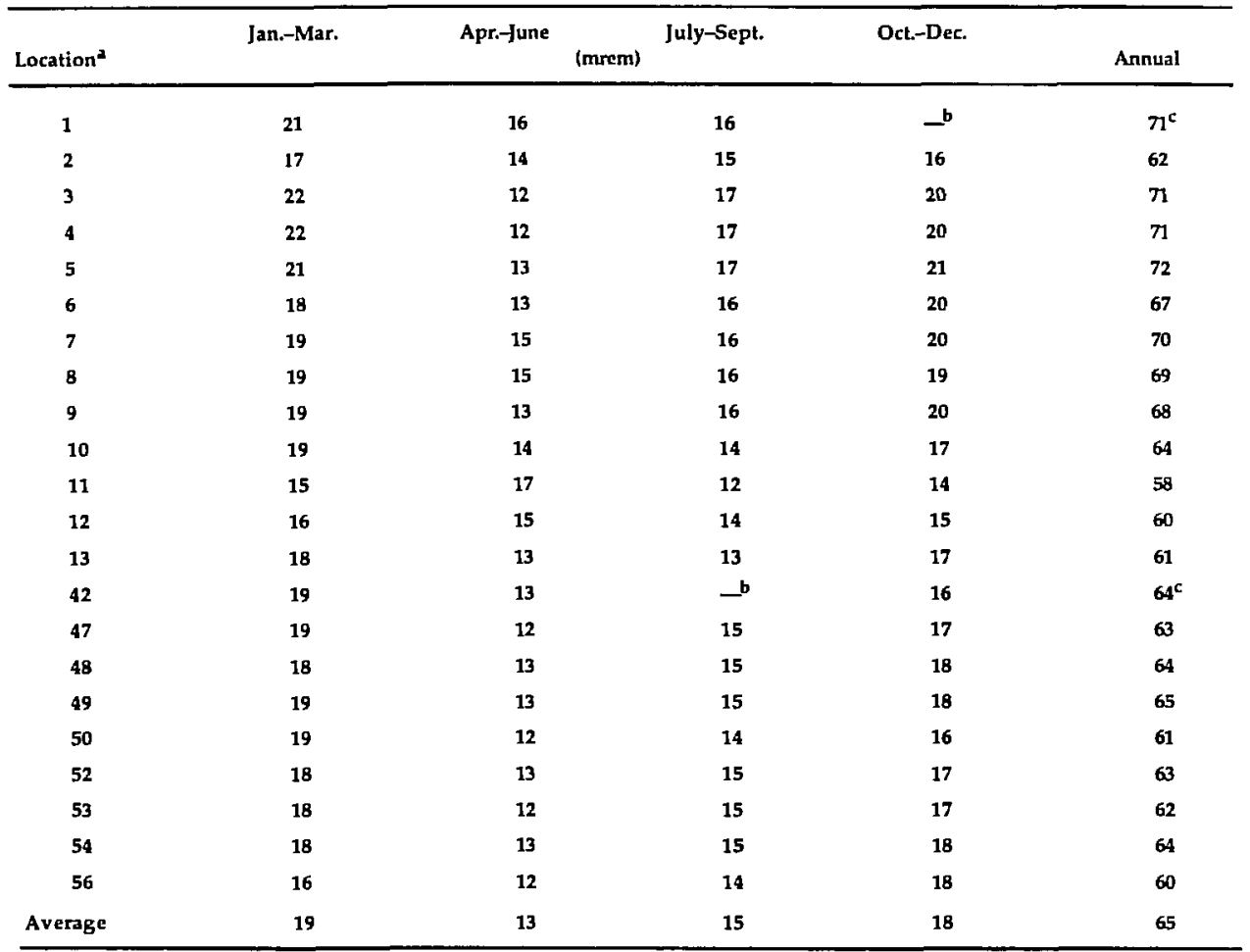

See Fig. 16.

b No data available; dosimeter was missing at collection time.

c The annual dose is calculated by avcraging the doses recorded for the available quarters. 
Table A-30. Environmental radiation measurements (TLD)_Livermore Valley.

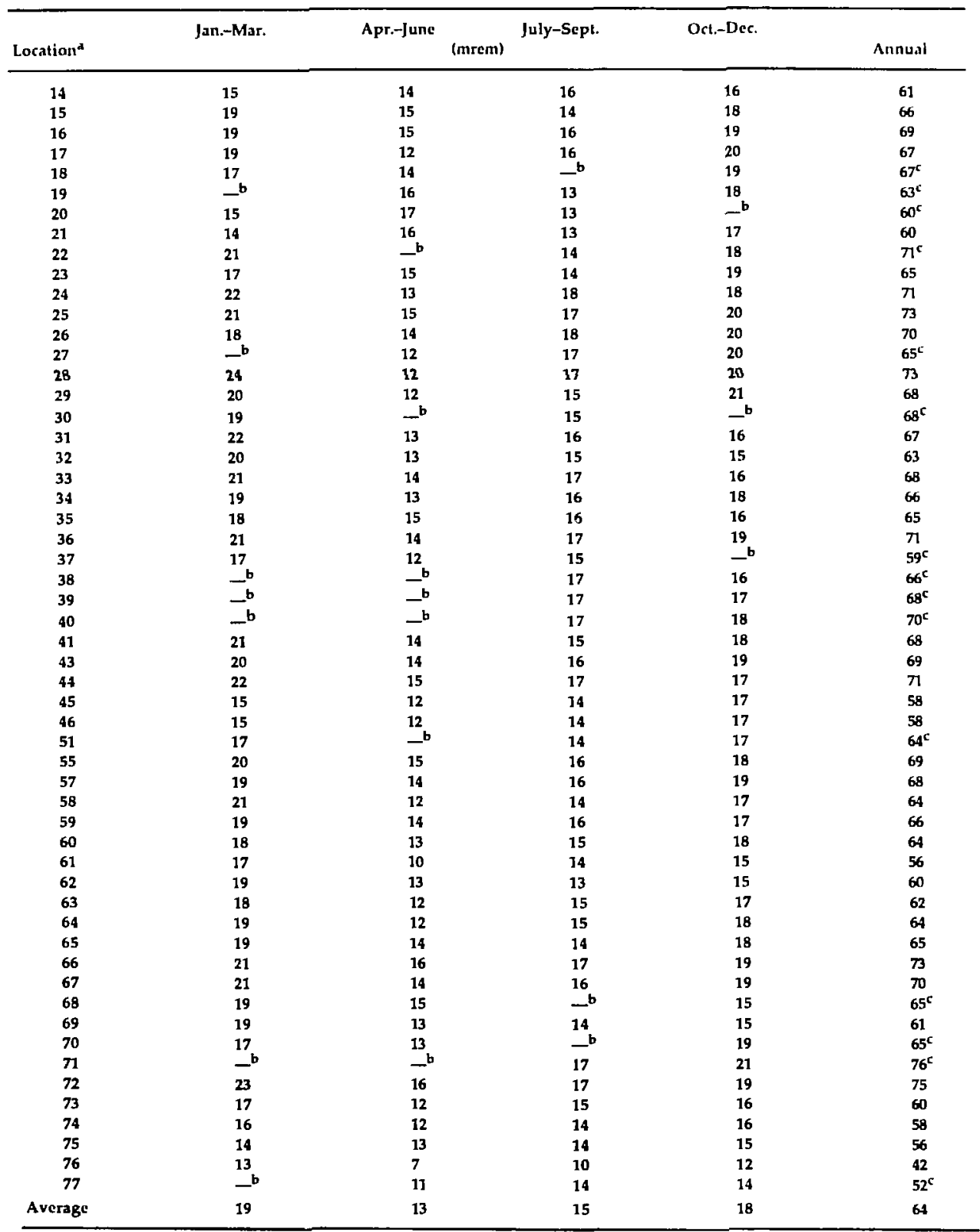

a See Fig. 17.

b No data available; dosimeter was missing.

c The annual dose is ealeulated by averaging the doses recorded for the available quarters. 
Table A-31. Environmental neutron monitoring-Livermore site perimeter.

\begin{tabular}{cccccc}
\hline Location & Jan.-Mar. & Apr.-Junc & July-Sept. & Oct.-Dec. & Total \\
\hline & & & & & \\
\hline & 1.0 & 1.6 & 1.0 & 0.8 & 4.4 \\
2 & 0.9 & 1.0 & 1.2 & 1.1 & 4.2 \\
3 & 1.1 & 5.7 & 1.4 & 1.0 & 9.2 \\
4 & 0.9 & 0.7 & 1.2 & 0.8 & 3.6 \\
5 & 1.1 & 1.6 & 1.0 & 0.8 & 4.5 \\
6 & 1.1 & 0.7 & 1.3 & 0.9 & 4.0 \\
7 & 1.2 & 1.3 & 1.1 & 0.8 & 4.4 \\
8 & 1.3 & 1.4 & 1.4 & 1.2 & 5.3 \\
Average & 1.1 & 1.8 & 1.2 & 4.9 & 5.0 \\
\hline
\end{tabular}

asee Fig. 16. 
Table A-32a. Water-quality parameters for Site 300 monitoring wells.

Parameters analyzed

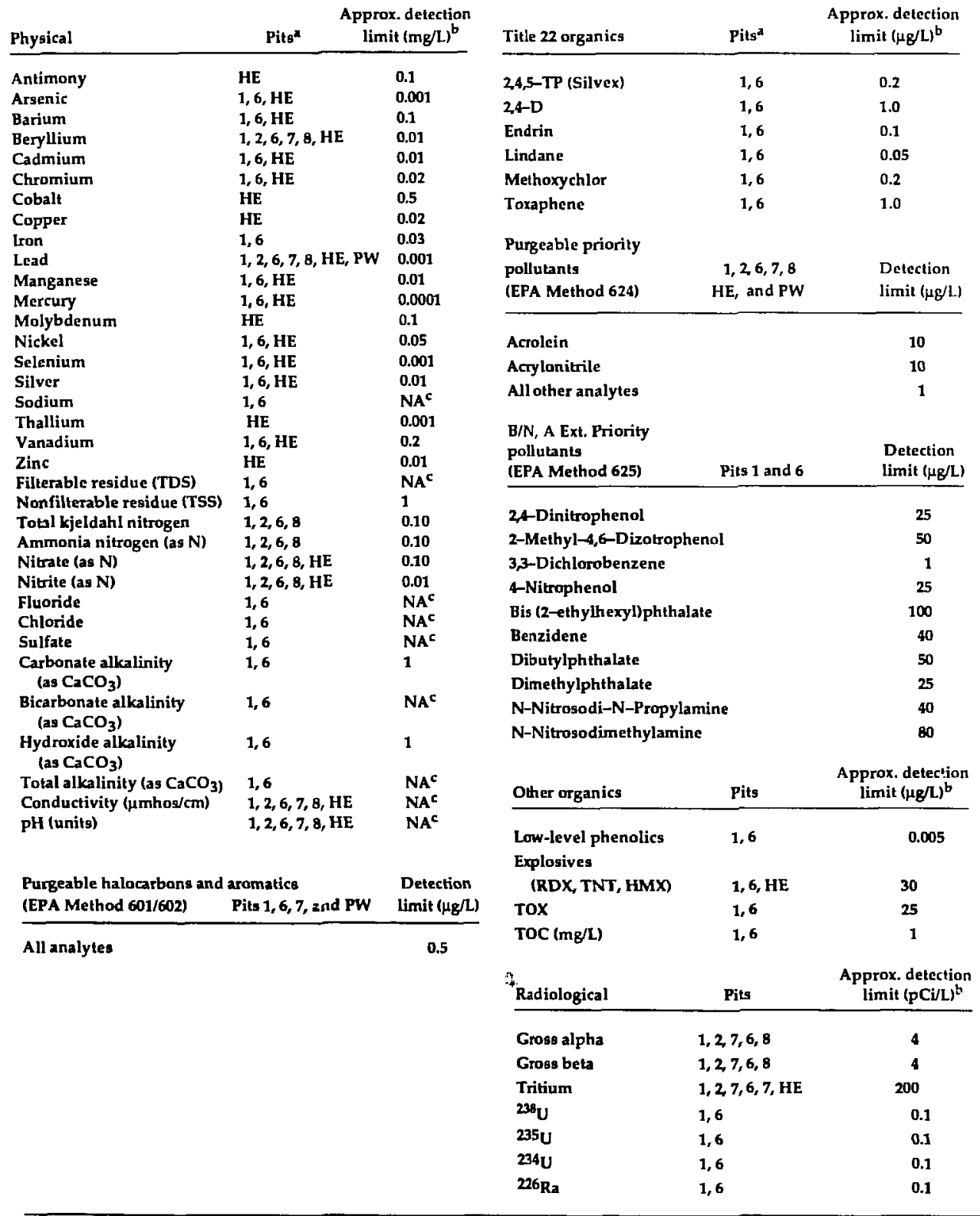

A $\mathrm{HE}=$ High-Explosive Surface Impoundment; PW = production wells.

b Detection limits can vary from sample to sample depending on such items as matrix interference and instrument sensitivity.

¿ Not applicable. 
Table A-32b. Pit 1 wells.

Positively delected parameters

K1-01C K1-02B

Well

Physical (mg/L)

\begin{tabular}{|c|c|c|c|c|c|c|c|c|}
\hline Arsenic & 0.010 & 0.010 & 0.011 & 0.010 & 0.014 & 0.014 & 0.013 & 0.013 \\
\hline Lead & 0.003 & 0.001 & 0.001 & 0.006 & 0.006 & 0.002 & $<0.001$ & $<0.001$ \\
\hline Manganest & 0.02 & 0.02 & 0.02 & 0.02 & $<0.01$ & $<0.01$ & $<0.01$ & $<0.01$ \\
\hline Nickel & $<0.05$ & $<0.05$ & 0.08 & 0.12 & 0.12 & 0.06 & $<0.05$ & $<0.05$ \\
\hline Sodium & 38 & 38 & 34 & 40 & 35 & 39 & 37 & 36 \\
\hline Filterable residue (TDS) & 369 & 354 & 342 & 360 & 335 & 358 & 339 & 340 \\
\hline Nonfltterable residue (TSS) & 1 & 7 & $<1$ & $<1$ & $\mathbf{5}$ & $<1$ & 13 & 3 \\
\hline Total kjcldahl nitrogen & 0.17 & 0.22 & 0.11 & 0.17 & $<0.10$ & $<0.10$ & $<0.10$ & $<0.10$ \\
\hline Nitrate (as $\mathbf{N}$ ) & 10.7 & 10.0 & 125 & 4.4 & 15.0 & 16.2 & 15.3 & 15.0 \\
\hline Fluoride & 0.33 & 0.33 & 0.27 & 0.36 & 0.46 & 0.39 & 0.44 & 0.41 \\
\hline Chloride & 45 & 37 & 33 & 36 & 36 & 40 & 38 & 37 \\
\hline Sulfale & 38 & 45 & 35 & 52 & 37 & 33 & 37 & 32 \\
\hline Selenium & 0.002 & 0.002 & 0.005 & 0.002 & $<0.001$ & 0.003 & 0.001 & $<0.001$ \\
\hline Mercury & 0.0002 & $<0.0001$ & $<0.0001$ & $<0,0001$ & $<0.0001$ & 0.0012 & 0.0003 & $<0.000$ \\
\hline Conductivity $\mu \mathrm{mhos} / \mathrm{cm}$ & 522 & 501 & 494 & 515 & 481 & 511 & 479 & 482 \\
\hline pH (units) & 7.8 & 7.4 & 7.8 & 7.7 & 7.5 & 7.0 & 7.8 & 7.8 \\
\hline
\end{tabular}

Organics

TOC (mg/L)

$\operatorname{TOX}(\mu g / \mathrm{L})$

Low-level phenolics ( $\mu / \mathrm{L}$ )

$\begin{array}{rrrrr}1 & 1 & 1 & 1 & 1 \\ 26 & <25 & <25 & <25 & <25\end{array}$

53

$\begin{array}{cr}1 & 2 \\ <25 & <25 \\ 0.045 & 0.25\end{array}$

Purgeable priority

pollutants $(\mu g / L)$

$\mathrm{C}_{5} \mathrm{H}_{12}$ hydracarbon ${ }^{2}$

$<1<1$

10

$<1$

$<1$
$<1$

$<1$
4

$<1$

$<1$

Toluene

Radiological (pCi/L)

Gross alpha
Gross beta
${ }^{238} \mathrm{U}$
${ }^{234} \mathrm{U}$

$\begin{array}{cc}<4 & <4 \\ <4 & <4 \\ 1.0 & 1.7 \\ 2.2 & 2.0\end{array}$

$<4$
$<4$
0.5
0.9

$<4$
$<4$
0.7
1.2

$<4$
$<4$
0.5
1.1

4
6
0.7
1.6

$\begin{array}{cc}<4 & <4 \\ <4 & 4 \\ 0.5 & <4 \\ 1.1 & 0.9\end{array}$

\footnotetext{
aemi-quantified result.
} 
Table A-32c. Pit 7 wells.

Positively detected parameters

\begin{tabular}{lllllll}
\multicolumn{9}{c}{ Well } & & \\
\hline K7-01 & K7-03 & K7-05 & K7-06 & NC7-25 & NC7-26 & NC7-47 \\
\hline
\end{tabular}

Physical (mg/L)

Lead

Conductivity $(\mu \mathrm{mhos} / \mathrm{cm})$

pH (units)

EPA Method $601(\mu \mathrm{g} / \mathrm{L})$

1,1-Dich loroethylene

Trans-1,2-Dichloroethylene

Trichloroethylene

1,1,2-Trichloroethane

1,1,1-Trichloroethane

Freon

Purgeable priority

pollutants $(\mu \mathrm{g} / \mathrm{L})$

Trimethyl silanol ${ }^{b}$

Radiological (pCi/L)

\section{Gross alpha}

Gross beta

Tritium

$\begin{array}{cc}0.8 & 2 \\ <0.5 & <0.5 \\ 5 & 5 \\ <0.5 & <0.5 \\ <0.5 & <0.5 \\ 1.8 & 1.2\end{array}$

$<0.5$

$<0.5$

$<0.5$

$<0.5$

$<0.5$

5.9

0.001

502

7.3

0.005
353
7.1

1.2

$\boldsymbol{L}^{2}$

0.021

390

7.0

3.018
-2
-2

$<0.5$

$<0.5$

$<0.5$

$<0.5$

$<0.5$

$<0.5$

$<1$

B

$<1$

$<1$

\footnotetext{
at applicable; well sampled by bailing.

b Semi-quantificd result.
}

\begin{tabular}{rrrrrrr}
$<4$ & $<4$ & $<4$ & $<4$ & 12 & $<4$ & $<4$ \\
8 & 6 & $<4$ & $<4$ & 13 & $<4$ & $<4$ \\
21600 & 137000 & $<200$ & $<200$ & 375000 & 2230 & $<200$ \\
\hline
\end{tabular}


Table A-32d. Pits 2, 8, and well NC2-07.

\begin{tabular}{|c|c|c|c|c|c|c|}
\hline \multirow{2}{*}{$\begin{array}{l}\text { Positively detected } \\
\text { paramsters }\end{array}$} & \multicolumn{6}{|c|}{ Well } \\
\hline & $\mathrm{K} 2-01 \mathrm{C}$ & K2-04 & K2-04D & K2-04S & K8-01 & NC2 -07 \\
\hline \multicolumn{7}{|l|}{ Physical (mg/L) } \\
\hline Nitrate (as N) & 8.4 & 1.7 & 9.4 & 9.3 & 10.8 & -2 \\
\hline Ammonia & 0.11 & 0.33 & $<0.10$ & $<0.10$ & $<0.10$ & -1 \\
\hline Total kjeldahi nitrogen & $<0.10$ & 0.33 & $<0.10$ & $<0.10$ & 0.22 & $-\mathbf{a}$ \\
\hline Lcad & 0.005 & $<0.001$ & $<0.001$ & $<0.001$ & 0.016 & $-{ }^{a}$ \\
\hline Conductivity $\left(\mu_{\mathrm{mhos}} / \mathrm{cm}\right)$ & 544 & 745 & 445 & 587 & 550 & 735 \\
\hline pH (units) & 7.2 & 6.9 & 6.8 & 6.7 & 7.7 & 7.7 \\
\hline \multicolumn{7}{|l|}{$\begin{array}{l}\text { Purgeable priority } \\
\text { pollutants }(\mu \mathrm{g} / \mathrm{L})\end{array}$} \\
\hline Chlorobenzene & $<1$ & $<1$ & $<1$ & $<1$ & 1.6 & $<1$ \\
\hline Froon & $<1$ & $<1$ & $<1$ & $\mathfrak{l}$ & $<1$ & $<1$ \\
\hline Trichloroethylene & $<1$ & $<1$ & $<1$ & $<I$ & 5.0 & $<1$ \\
\hline \multicolumn{7}{|l|}{ Radiological (pCi/L) } \\
\hline Gross alpha & $<4$ & $<4$ & $<4$ & $<4$ & 9 & $<4$ \\
\hline Gross beta & 7 & $<4$ & $<4$ & $<4$ & 10 & 10 \\
\hline${ }^{3} \mathbf{H}$ & 43375 & 1250 & 6160 & 99300 & 246 & $<200$ \\
\hline
\end{tabular}

a Not analyzed for these parameters. 
Table A-32e. Pit 6 wells.

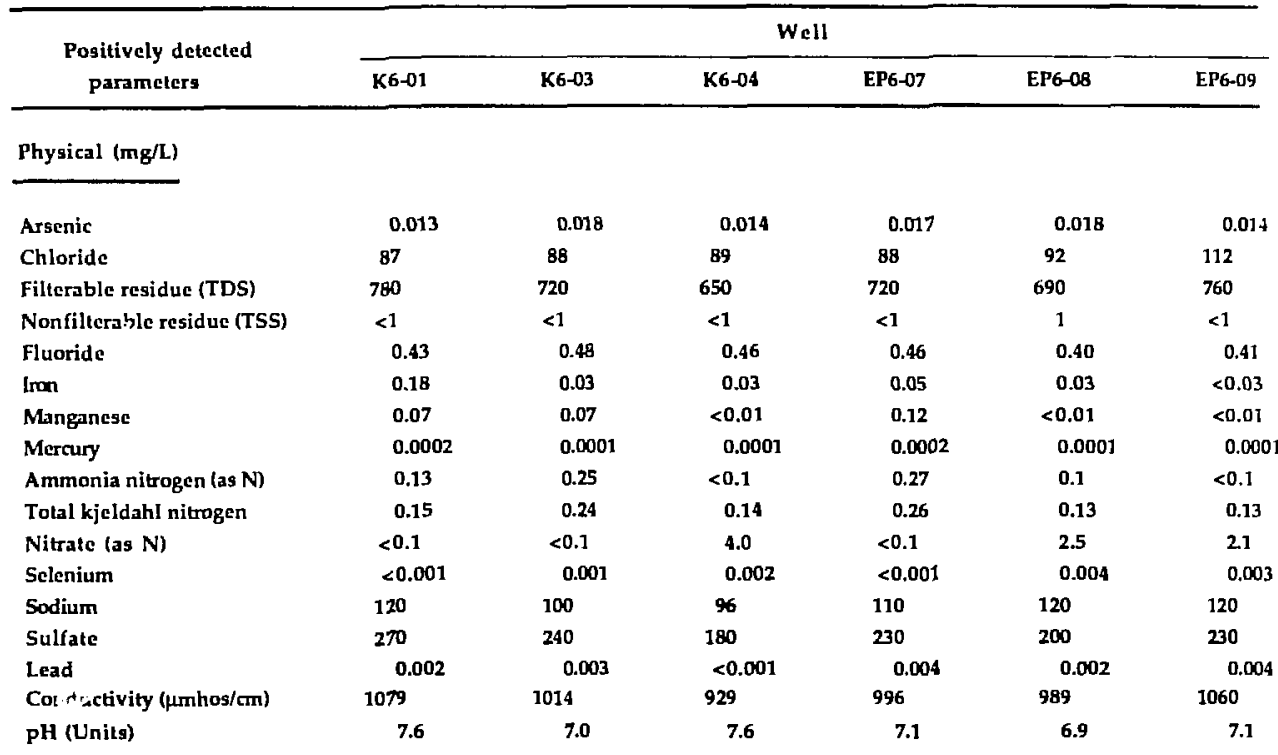

Organics

TOC (mg/L)

TOX $(\mu g / L)$

Low-level phenolics $(\mu \mathrm{g} / \mathrm{L})$

$\begin{array}{cccccc}1.3 & 1 & 1 & 1 & 1 & 1 \\ <25 & <25 & <25 & <25 & <25 & 42 \\ 0.008 & <0.005 & <0.005 & 0.008 & <0.005 & <0.005\end{array}$

EPA Method 601 ( $\mu \mathrm{g} / \mathrm{L})$

Chloroform

Tetrachlorocthene

1,2-Dichloroethane

Trichloroethylene

Purgeable priority pollutants $(\mu \mathrm{g} / \mathrm{L})$

\section{$<0.5$}

$<0.5$

$<0.5$

$<0.5$

$<1$

$<1$

$<0.5$
$<0.5$
$<0.5$
$<0.5$

$<0.5$

$<0.5$

$<0.5$

$<0.5$
$<0.5$

$<0.5$

$<0.5$

$<0.5$
0.7

0.8

$<0.5$

$<0.5$
$<0.5$ $<0.5$

0.7

2.3

Trichlorofluoromethane

Radiological (pCi/L)

Gross alpha
Gross beta
${ }^{238} \mathrm{U}$
${ }^{234} \mathrm{U}$

$<4$

0.4

0.5

$<4$

0.2

0.1
$<4$

10

0.5

0.7
$<1$

$<4$

9

0.1

0.3
11

9

0.5

0.7
$<4$

11 
Table A-32f. High-Explosive Process-Water Surface Impoundment.

\begin{tabular}{|c|c|c|c|c|c|}
\hline \multirow{2}{*}{$\begin{array}{l}\text { Positivcly delected } \\
\text { parameters }\end{array}$} & \multicolumn{5}{|c|}{ Well } \\
\hline & $817-01$ & $817-02$ & $817-03$ & $817-04$ & $817-03 A$ \\
\hline \multicolumn{6}{|l|}{ Physical (mg/L) } \\
\hline Selenium & 0.039 & 0.078 & 0.015 & 0.019 & - \\
\hline Arsenic & 0.048 & 0.060 & 0.047 & 0.040 & $-\mathbf{a}$ \\
\hline Barium & 0.1 & $<0.1$ & $<0.1$ & $<0.1$ & $-\mathbf{a}$ \\
\hline Nitrate (as N) & 22 & 22 & 23 & 25 & $-\mathbf{a}$ \\
\hline Zinc & 0.01 & 0.06 & $<0.01$ & 0.07 & - \\
\hline Vanadium & 0.2 & 0.2 & 0.2 & 0.2 & $-\mathbf{a}$ \\
\hline Conductivity $(\mu \mathrm{mhos} / \mathrm{cm})$ & 1462 & 2507 & 2024 & 1944 & $-\mathbf{a}$ \\
\hline pH (units) & 7.3 & 7.8 & 7.6 & 7.3 & - \\
\hline \multicolumn{6}{|l|}{ Organics } \\
\hline ToC (mg/L) & 1.5 & 2 & 2 & 2 & - \\
\hline $\operatorname{TOX}(\mu g / L)$ & 25 & 27 & 36 & 32 & $-^{a}$ \\
\hline $\operatorname{RDX}\left(\mu_{g} / L\right)$ & 47 & $<30$ & $<30$ & $<30$ & $<30$ \\
\hline \multicolumn{6}{|l|}{$\begin{array}{l}\text { Purgeable priority } \\
\text { pollutants }(\mu \mathrm{g} / \mathrm{L})\end{array}$} \\
\hline Trichlorocthylene & $<1$ & $<1$ & 23 & 12 & 113 \\
\hline Toluene & $<1$ & 7 & $<1$ & $<1$ & $<1$ \\
\hline
\end{tabular}

\footnotetext{
Not analyzed for these parameters.
} 
Table A-32g. Production wells.

\begin{tabular}{|c|c|c|c|c|c|c|c|c|}
\hline \multirow{2}{*}{$\begin{array}{l}\text { Positively detected } \\
\text { parameters }\end{array}$} & \multicolumn{8}{|c|}{ Well } \\
\hline & 1 & 3 & $4^{3}$ & 6 & 7 & 8 & $1 \mathrm{~B}^{\mathrm{a}}$ & $19^{a}$ \\
\hline \multicolumn{9}{|l|}{ Physical (mg/L) } \\
\hline Lead & 0.004 & 0.018 & 0.007 & 0.010 & $<0.001$ & 0.002 & 0.032 & $<0.001$ \\
\hline \multicolumn{9}{|l|}{$\begin{array}{l}\text { Purgeable priority } \\
\text { pollutants }\left(\mu \mathrm{g}^{\prime} \mathrm{L}\right)\end{array}$} \\
\hline Benzene & $<1$ & 1.2 & $<1$ & $<1$ & $<1$ & $<1$ & $<1$ & $<1$ \\
\hline Freon & $<1$ & $<1$ & 2 & $<1$ & $<1$ & $<1$ & $<1$ & $<1$ \\
\hline 1,2-Dichloroethane & $<1$ & 24 & $<1$ & 67 & $<1$ & $<1$ & $<1$ & $<1$ \\
\hline Methyllene chloride & $<1$ & 45 & $<1$ & 29 & $<1$ & $<1$ & $<1$ & $<1$ \\
\hline Tetrachloroethylene & $<1$ & $<1$ & $<1$ & $<1$ & 2 & $<1$ & $<1$ & $<1$ \\
\hline Trichloroethylene & $<1$ & $<1$ & $<1$ & 4 & 28 & $<1$ & $<1$ & $<1$ \\
\hline \multicolumn{9}{|l|}{ EPA Methad $601\left(\mu_{g} / L\right)$} \\
\hline Trans-1,2-Dichlorocthylene & $<0.5$ & $<0.5$ & $<0.5$ & $<0.5$ & 0.7 & $<0.5$ & $<0.5$ & $<0.5$ \\
\hline Toluene & $<0.5$ & 0.6 & $<0.5$ & 2 & $<0.5$ & $<0.5$ & $<0.5$ & $<0.5$ \\
\hline
\end{tabular}

a Only wells 4, 18, and 19 are currently used for the production of drinking water. 
Table A-33. Radioactive effluent releases from LLNL, 1981-1987.

\begin{tabular}{llccc}
\hline & \multicolumn{2}{c}{ Airborne effluents (Ci) } & \multicolumn{2}{c}{ Liquid effluents (Ci) } \\
\cline { 2 - 5 } Year & ${ }^{3} \mathrm{H}$ & ${ }^{13} \mathrm{~N}-15 \mathrm{O}$ & 344 & $239 \mathrm{Pu}$ \\
\hline 1981 & 2620 & 384 & 6.0 & $9.2 \times 10^{-5}$ \\
1982 & 2014 & 855 & 1.6 & $4.3 \times 10^{-6}$ \\
1983 & 3245 & 51 & 1.7 & $6.7 \times 10^{-6}$ \\
1984 & 7354 & 520 & 1.7 & $3.2 \times 10^{-6}$ \\
1985 & 2204 & 113 & 3.6 & $4.8 \times 10^{-6}$ \\
1986 & 1254 & 62 & 2.0 & $1.5 \times 10^{-5}$ \\
1987 & 275 & 1.4 & $6.9 \times 10^{-4}$ \\
\hline
\end{tabular}

Table A-34a. Radiation dose from the air pathway, all facilities during 1987 (Clean Air Act Code)."

\begin{tabular}{|c|c|c|c|c|}
\hline Facility & $\begin{array}{l}\text { Nuclide/ } \\
\text { emission } \\
\text { (Ci) }\end{array}$ & $\begin{array}{c}\text { Dose at site } \\
\text { perimeter } \\
\text { (mrem) } b\end{array}$ & $\begin{array}{l}\text { Dose to nearest } \\
\text { resident } \\
\text { (mrem) })^{\mathbf{b}}\end{array}$ & $\begin{array}{l}\text { Dose at maximum } \\
\text { of } f-s i t e \text { exposure } \\
\text { (mrem) }\end{array}$ \\
\hline \multicolumn{5}{|l|}{ LLNL } \\
\hline Tritium facility & ${ }^{3} \mathrm{H} / 2634$ & 0.07 & 0.05 & 0.07 \\
\hline $\begin{array}{l}\text { Insulating } \\
\text { core accelerator }\end{array}$ & ${ }^{3} \mathrm{H} / 38$ & 0.003 & $\mathbf{0}$ & 0.003 \\
\hline $\begin{array}{l}\text { Ratating torget } \\
\text { neutron source }\end{array}$ & ${ }^{3} \mathrm{H} / 78.5$ & 0.004 & 0.003 & 0.004 \\
\hline Incinerator & ${ }^{3} \mathrm{H} / 0.22$ & o & 0 & 0 \\
\hline Linear aceclerator & ${ }^{13} \mathrm{~N}-15 \mathrm{O} / 48$ & 0.004 & 0.003 & 0.004 \\
\hline Total (LLNL) & & 0.081 & 0.056 & 0.081 \\
\hline Percent of Federal & & $0.3 \%$ & $0.2 \%$ & $0.3 \%$ \\
\hline \multicolumn{5}{|l|}{ Site 300} \\
\hline ATA $^{d}$ & ${ }^{13} \mathrm{~N}-15 \mathrm{O} / 4.1$ & 0.002 & 0 & 0.002 \\
\hline $\begin{array}{l}\text { Percent of Federal } \\
\text { Emission Standard }\end{array}$ & & $0.008 \%$ & 0 & 0.0089 \\
\hline
\end{tabular}

a These doses were calculated pursuant to the National Emissions Standards for Hazardous Air Pollutants (Clean Air Act), 40 CFR 61, Subpart H.

b These doses are dose equivalents calculated using the ICRP 2 method (i.e., whole body/critical organ concept). These calculations were performed using the EPA approved Clean Air Act Code, which contains the AIRDO5-EPA and RADRISK models for calcubting atmospheric transport, exposure, and dose. Site-specific meteorogical data was used except for atmospheric stability, which was obtained from Oakland Airport for the period 1960-1964.

c The Federal Emission Standards for radionuclides (conbined in 40 CFR 61, Subpart H) limit doses to the publie to 25 mrem/y to the whole body and $75 \mathrm{mrem} / \mathrm{y}$ to any critical organ.

d Advanced test accelerator. 
Table A-34b. Estimated radiation dose to the public from LLNL airborne effluents during 1987 (Continuous-Point-Source Code).

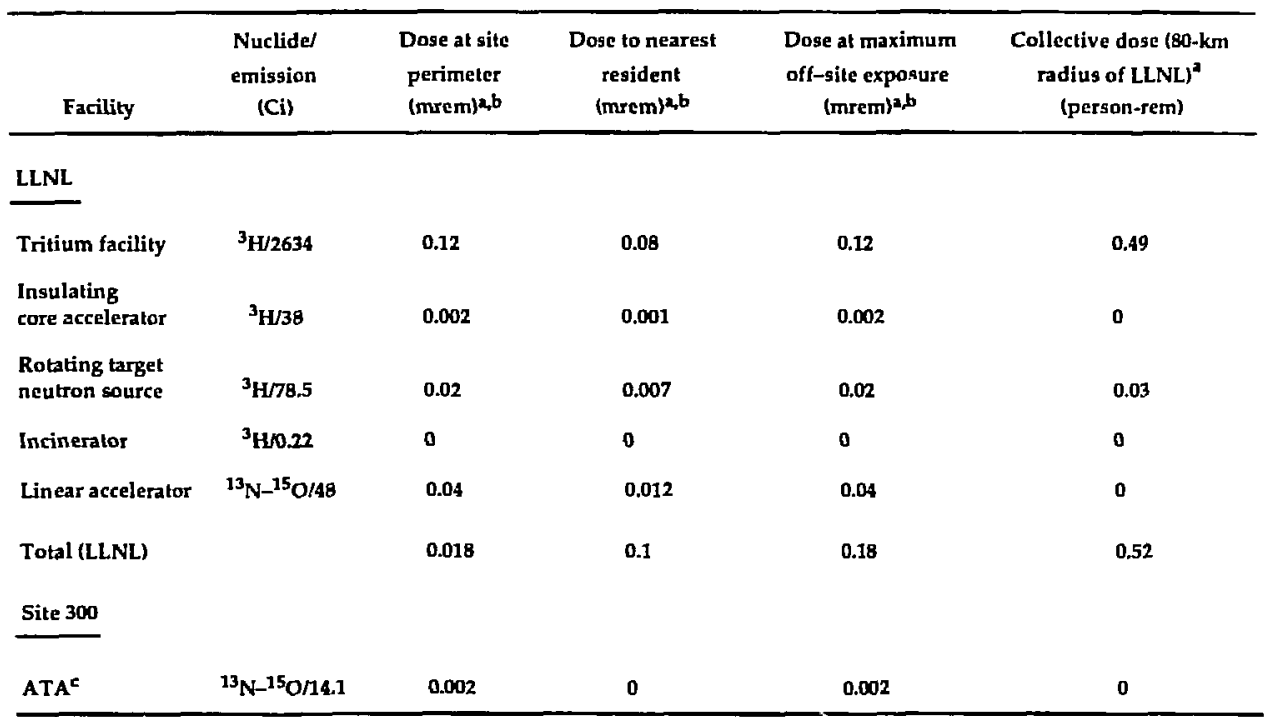

a Doses are based on the 1329 Ci of HTO released by LLNL. The dose due to the 1422 Ci of HT released by LLNL does nol add significantly to the total. SNLL emitted about $570 \mathrm{Ci}$ of $\mathrm{HTO}$, which are not included in these calculations.

b This dose represents the 50-y committed effective dose equivalent.

during 1987. Doge calculations were made using the Continuous-Point-Source computer code.

c Advanced test accelerator. ATA accounts for the total emission at Site 300 . 
Table A-34c. Summary of radiological dose assessment for 1987.

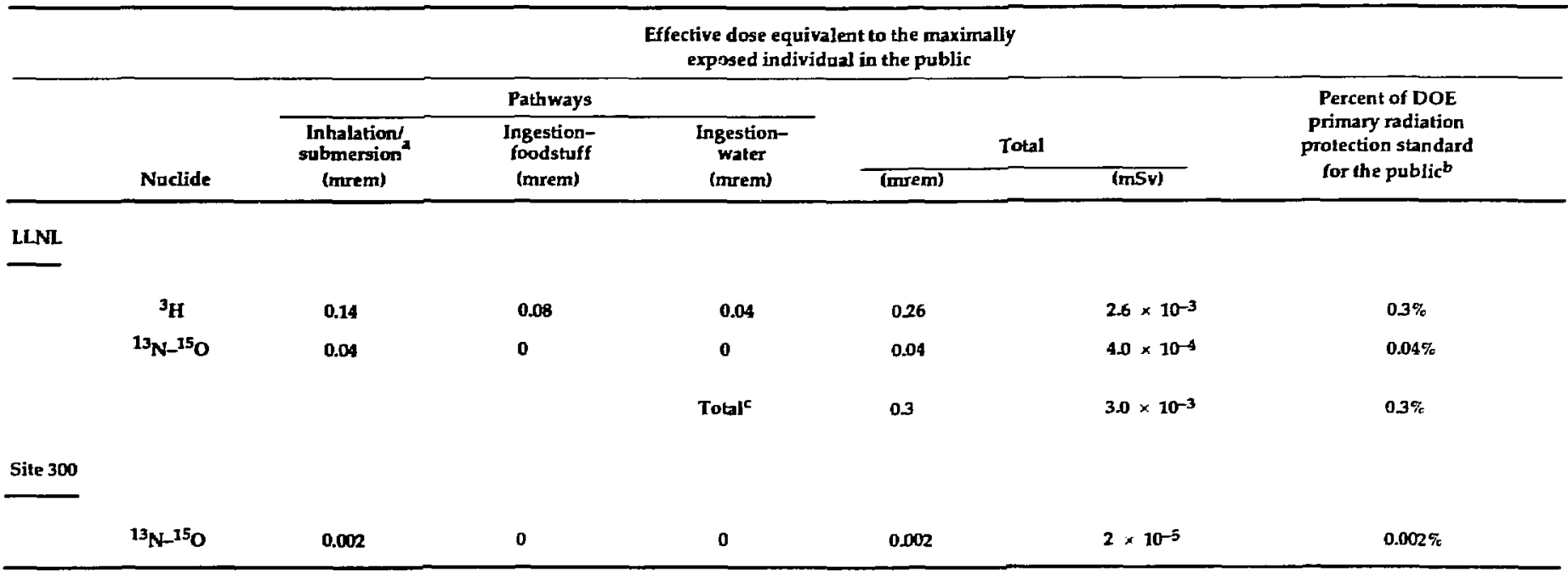

\footnotetext{
2 The inhalation/sabmersion dose was derived using the Continuous-Point-Source code and represents committed effective dose equivalents.

b The primary DOE radiation standard for protection of the public (all sources and all palhways) is $100 \mathrm{mrem} / \mathrm{y}$.

c This dose is the maximum potential dose to a member of the public from all sources and all exposure pathways.
} 
Table A-34d. Comparison of radiation doses-1987.

Location/suurce

Individual dose

Population dosc ${ }^{a}$ (mrem) (person-rem)

LENL sources

Maxinum of - -site doseb

LLNL atmospheric emissions

0.18

0.52

LLNL liquid emissions

0

0

Site 300

0.002

0

Other Sources

Natural radloactivity ${ }^{c}$

Cosmic radiation

40

200000

Terrestrial radiation

50

250000

Internal (food consumption)

28

140000

Radon

200

1000000

Subtotal (natural)

318

1600000

Medical radiation

(Diagnostle procedurea)

91

460000

Weapons teat fallout

5

25000

Total other sources

414

2085000

The population dose is the collective (combined) dose for all individuals residing within an 80-km radius of LLNL.

b These doses represent the maximum committed effective dose equivalent from all LLNL emissions. It is calculated using the most conservative exposure assumption and is not a dose actually received by any member of the public.

cThese values vary with location and represent approximate averages in the vicinity of LLNL.

d This dose is an average over the U.S. population. 
Table A-35a. Quality assurance analyses for the EPA's Environmental Radioactivity Laboratory Intercomparison Studies Program.

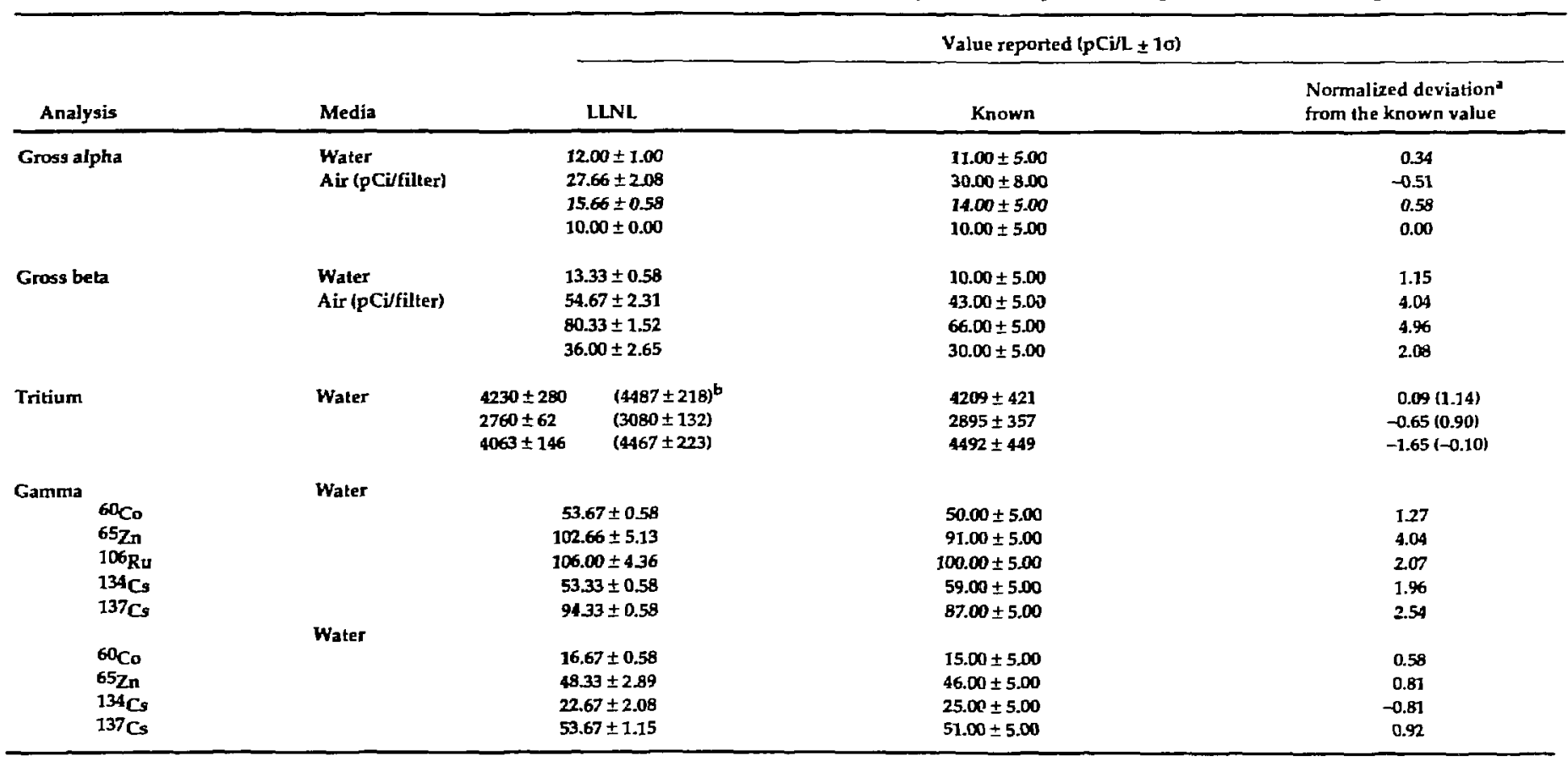

Acceptable deviations are $\leq \pm 3$.

b Data in parentheses are provided by the Nuclear Chemistry Division. All other data are provided by the Hazards Control Department. 
Table A-35b. Quality assurance for the DOE Environmental Measurements Laboratory (EML) Quality Assessment

Program.a,b

\begin{tabular}{|c|c|c|c|c|}
\hline Analysis & Media & $\begin{array}{l}\text { LLNL } \\
\text { value }\end{array}$ & $\begin{array}{l}\text { EML } \\
\text { value }\end{array}$ & $\begin{array}{c}\text { LLNL/EML } \\
\text { ratio }\end{array}$ \\
\hline \multirow[t]{2}{*}{${ }^{7} \mathrm{Be}$} & Air & 1000 & 896 & 1.12 \\
\hline & & 4400 & $(\leq \Delta)$ & 0.95 \\
\hline${ }^{60} \mathrm{Co}$ & & 396 & 444 & 0.89 \\
\hline \multirow[t]{2}{*}{${ }^{137} \mathrm{Cs}_{\mathrm{s}}$} & & 316 & 290 & 1.09 \\
\hline & & 469 & 470 & 1.00 \\
\hline \multirow[t]{2}{*}{${ }^{238} \mathrm{U}$} & & 1.97 & 1.71 & 1.15 \\
\hline & & 2.35 & 1.88 & 1.25 \\
\hline \multirow[t]{2}{*}{$209 \mathrm{PL}$} & & 5.09 & 5.23 & 0.97 \\
\hline & & 5.79 & 5.68 & 1.02 \\
\hline \multirow[t]{2}{*}{$\mathbf{4 0} \mathrm{K}$} & Soil & 23.6 & 20.0 & 1.18 \\
\hline & & 0.80 & 1.05 & 0.76 \\
\hline \multirow[t]{2}{*}{${ }^{137} \mathrm{Cs}$} & & 0.21 & 0.21 & 1.01 \\
\hline & & 0.49 & 0.48 & 1.02 \\
\hline \multirow[t]{2}{*}{${ }^{239} \mathbf{P u}$} & & 0.044 & 0.029 & 1.52 \\
\hline & & 2,35 & 1.88 & 1.25 \\
\hline \multirow[t]{2}{*}{${ }^{3} \mathbf{H}$} & Water & 29.5 & 33.7 & 0.88 \\
\hline & & 19.7 & 19.1 & 1.03 \\
\hline \multirow[t]{2}{*}{${ }^{137} \mathrm{Cs}$} & & 3.63 & 2.34 & 1.55 \\
\hline & & 3.74 & 2.28 & 1.64 \\
\hline \multirow[t]{2}{*}{ 239Pu } & & 0.071 & 0.137 & 0.52 \\
\hline & & 0.186 & 0.266 & 0.70 \\
\hline
\end{tabular}

all values are relative. The exponents are not included; therefore, values do not indicate actual concentrations.

b All data were provided by LLNL's Nuclear Chemistry Division. 
Table A-36. Quality assurance -duplicate sampling.

\begin{tabular}{|c|c|c|c|c|c|c|c|}
\hline \multirow[b]{2}{*}{ Media } & \multirow[b]{2}{*}{ Parameter } & \multirow[b]{2}{*}{ Data capture $(\%)^{2}$} & \multirow[b]{2}{*}{ Precision ${ }^{b}$} & \multirow[b]{2}{*}{ Ratioc } & \multicolumn{3}{|c|}{ Regression Analysisd } \\
\hline & & & & & $\begin{array}{l}\text { ComelationW } \\
\text { coefficient }\end{array}$ & Slope & Y-intercept \\
\hline \multicolumn{8}{|l|}{ Sewage } \\
\hline LLNL & ${ }^{3} \mathbf{H}$ & 97 & $+218 /-158$ & & 0.97 & 0.99 & 2.6 \\
\hline LWRP & ${ }^{3} \mathbf{H}$ & & $+59 /-80$ & & 0.08 & -0.08 & 3.7 \\
\hline Water & & 95 & & & & & \\
\hline Livermore Valley & ${ }^{3} \mathbf{H}$ & & & 1.04 & & & \\
\hline Site $\mathbf{3 0 0}$ & ${ }^{3} \mathbf{H}$ & & & 216 & & & \\
\hline Vegetation & & 96 & & & & & \\
\hline Livermore Valley & ${ }^{3} \mathbf{H}$ & & & 0.98 & & & \\
\hline Site $\mathbf{3 0 0}$ & ${ }^{\mathbf{3}} \mathbf{H}$ & & & 8.51 & & & \\
\hline \multirow[t]{3}{*}{ Air } & $239 \mathrm{Pu}$ & 97 & $+85 /-42$ & & 0.95 & 1.13 & 0.0 \\
\hline & $\mathbf{3}_{\mathbf{H}}$ & 94 & $+105 /-87$ & & 0.85 & 0.75 & 0.6 \\
\hline & Be & 97 & $+383 /-192$ & & 0.16 & -0.16 & 0.05 \\
\hline Soil & ${ }^{239} \mathrm{Pu}$ & 100 & & 0.95 & & & \\
\hline \multirow[t]{3}{*}{ Groundwater } & TOC & 97 & & 123 & & & \\
\hline & $\operatorname{Tox}$ & & & 2.09 & & & \\
\hline & As & & & 0.98 & & & \\
\hline Milk & ${ }^{3} \mathbf{H}$ & 83 & & 0.83 & & & \\
\hline
\end{tabular}

a Ratio of samples collected for that medium to the number of samples scheduled to be collected.

b Calcalated according to the methodology in Quality Assurance Handbook for Air Pollution Measurement Systems (EPA 1976) for idata sets with more than 8 valid data pairs.

' Only used for data sets with less than 8 valid data pairs. Value is ratio of $Q A$ sample/routine sample.

d Only calculated for data sets with more than 8 valid data pairs. 
Appendix B. Statistical Methods 
[he tollownth stalletlial methode were appled to the data prenented in thes report.

Lower Limit of Detection (LLD). The l.1.D are indicated on the tables be the "less than or equal to" 1- Ingn for computation of average values and errors actual data points (when availahle) were used in

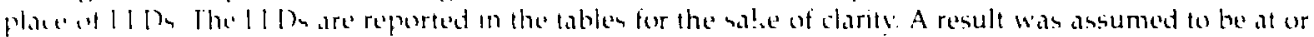

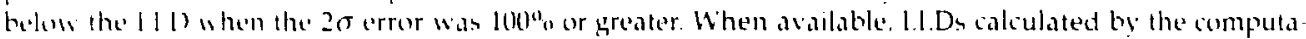
tomal pregrame were und. When attal data points were avalable, the data point plus the 20 error was uned to give a conservatue estimate.

Distribution Analysis. For the 1986 Envirommental Monitoring Annual Report (Holland et al.. |4k7) an eifort was made to determine the distribution characteristics of data sets before calculating summary statsstics. The differences in summary statistics were found to be of little significance, and the process was verv time consuming. Conseyuently, for this report, all data sets have heen treated as though thes were nurmally distributed.

Reporting. For sample sets containing few L.DS or extreme values (or those for which actual values helas the |I.D are avalable) numbers are reported as the arithmetic mean \pm two standard deviations. for bample nets combining many (one-thirt or more of the total) LLDs or extreme values (for which actual

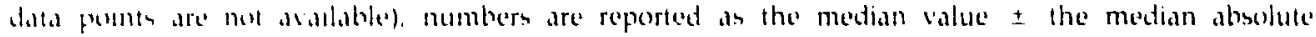
dusation. 
Appendix C. Radiation Protection Standards 


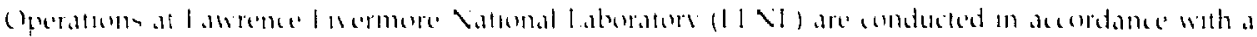

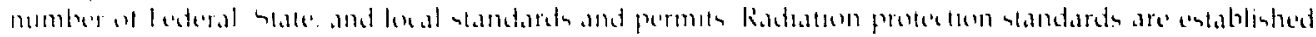

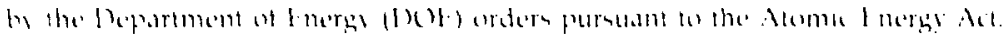

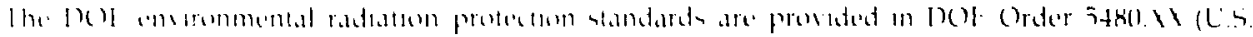

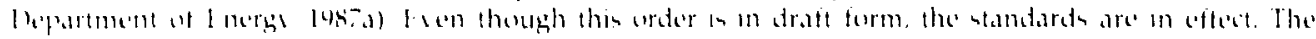

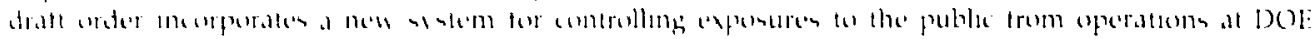

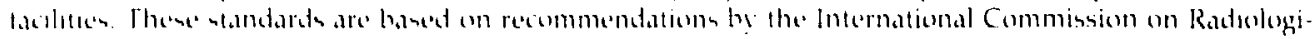

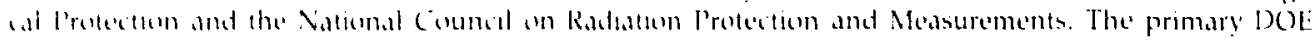

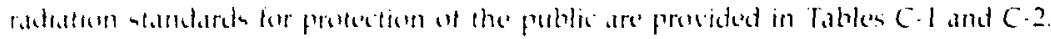

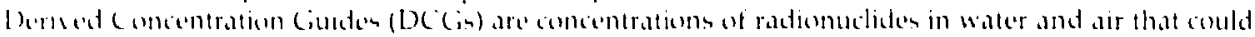

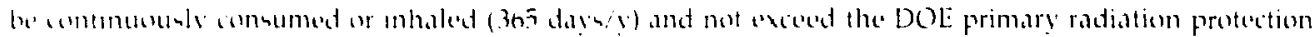

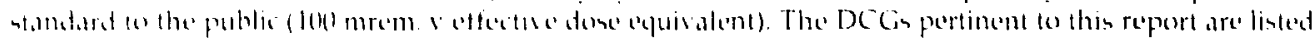
in I.1Wh.' ?

Table $(-1$. DOE radiation standard to the public: all pathways and all sources."

I ypusuru

l'rolunged texpoumice

Cocisional oxposure

Thene limits are based on the dose to the maximally esposed individual in an uncontrolled area.

"Ihe "eflective dase sopuivalent" in defined as the sum of the effective dose syuivalent trom external radiation and the committed $(50-y)$ offective dose repuisalent from ingestion and inhalation during the calendar year.

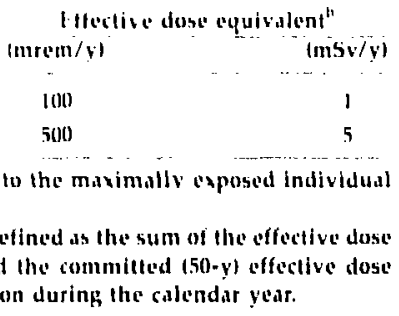

Table C-2. Air pathway only."

\begin{tabular}{|c|c|c|}
\hline \multirow[b]{2}{*}{ trpusure } & \multicolumn{2}{|c|}{ Dose equivalent } \\
\hline & $(\mathrm{mrem} / \mathrm{y})$ & $(\mathrm{mS} v / y)$ \\
\hline Whole body & 25 & 0.25 \\
\hline Any organ & 75 & 0.75 \\
\hline
\end{tabular}

Table C-3. Derived concentration guides.

\begin{tabular}{|c|c|c|}
\hline Nuclide & $\begin{array}{c}\text { Concentration in dir } \\
(\mu \mathrm{Ci} / \mathrm{mL})\end{array}$ & $\begin{array}{c}\text { Concentration in water } \\
\qquad(\mu \mathrm{Ci} / \mathrm{mL})\end{array}$ \\
\hline 'H & $2 \cdot 10^{\circ}$ & $2 \cdot 10^{t}$ \\
\hline "Ho & $5 \cdot 10^{x}$ & $1 \cdot 10^{1}$ \\
\hline${ }^{17} N$ & $2 \cdot 10^{4}$ & - \\
\hline${ }^{15} 0$ & $2 \cdot 10^{\prime \prime}$ & - \\
\hline${ }^{10} \mathrm{~K}$ & $9 \cdot 10^{111}$ & $7 \cdot 10^{\mathrm{k}}$ \\
\hline${ }^{111 h} \mathbf{R u}$ & $3 \cdot 10^{11}$ & $6 \cdot 10^{h}$ \\
\hline${ }^{125} \mathrm{Sb}$ & $1 \cdot 10^{4}$ & $6 \cdot 10^{5}$ \\
\hline $1 " \mathrm{Cs}$ & $4 \cdot 10^{111}$ & $3 \cdot 10^{\mathrm{h}}$ \\
\hline${ }^{1 H} \mathrm{Cu}$ & $3 \cdot 10^{11}$ & $7.10^{\prime \prime}$ \\
\hline $215 \mathrm{U}$ & $1 \cdot 10^{11}$ & h. $10^{\circ}$ \\
\hline$\therefore / 4 \mathrm{~L}$ & $1 \cdot 10^{11}$ & h. $10^{\circ}$ \\
\hline$: 14 \mathrm{~T} u$ & $2 \cdot 10^{14}$ & $3 \cdot 10^{\mathrm{h}}$ \\
\hline
\end{tabular}


The State of California (1977) specifies maximum contaminant levels ( $\mathrm{MCl}$.s) for public water supplies as follows:

Groms alpha particle activity (including

:inkal but exduting Rn and (l)

$\begin{array}{rr}- & 15 \mu \mathrm{Ci} / \mathrm{L} \text { or } 1.5 \times 10^{4} \mu \mathrm{Ci} / \mathrm{ml} . \\ - & 50 \mu \mathrm{Ci} / \mathrm{l} \text {. or } 5.0 \times 10^{\circ} \mu \mathrm{Ci} / \mathrm{ml} . \\ - & 20000 \mathrm{CCi} / \mathrm{L} \text { or } 2.0 \times 10^{5} \mu \mathrm{Ci} / \mathrm{ml} .\end{array}$

Tritium

In the draft order, no standards have been provided for gross alpha and grose beta activity. Altholgh not a DOE reguirement, gross activity medsurements have been included in this report for historical continuity: 


\section{Appendix D. Sampling and Analytical Procedures for Environmental Monitoring at Lawrence Livermore National Laboratory}




\section{Introduction}

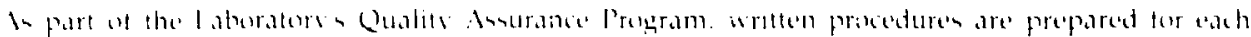

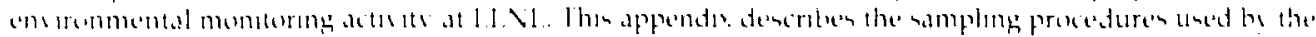

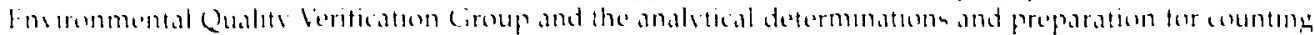

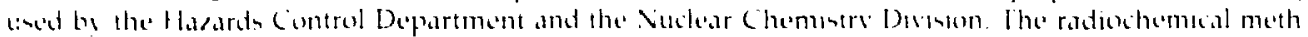

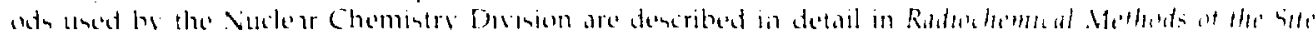

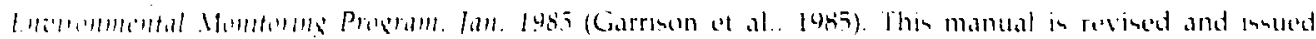

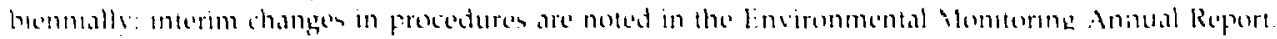

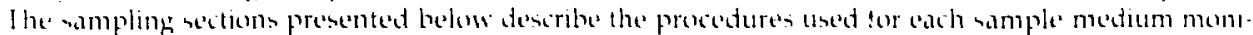

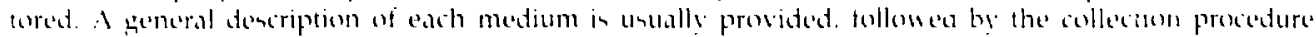

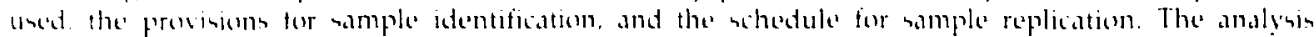

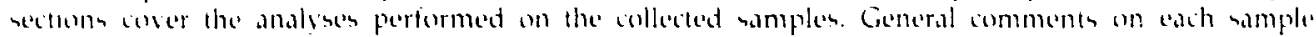

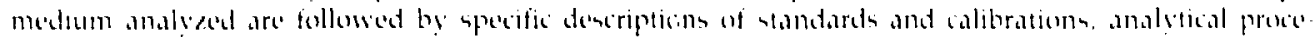

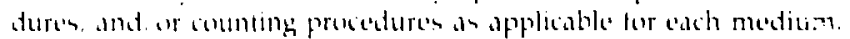

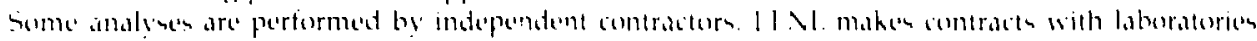

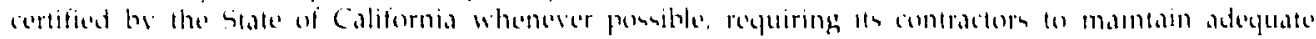

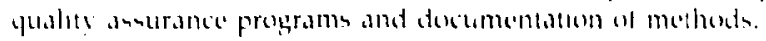

\section{Air Sampling}

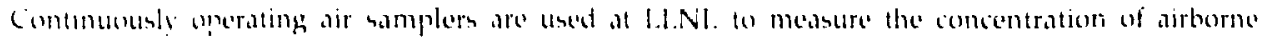
particulate radionetivits, beryllium, and tritiated water Somplers placed at six locations around the Livermore site perimeter and at nine !ncation at Site 300 measure particulate radioactivity and beryllium. Particulate radicactivity is also measured at 11 off-site locations near the livermore site. Tritiateci water samplers are operated at the six perineter locations and at six off-site locations. In all cases, the samplers are positioned to ressonably ensure that any significant concentration of effluents from L.LNL operations would be detected, regardless of local meteorolog!.

\section{Collection}

\section{Particulates}

Samples taken at the Livermore site perimeter, selected off-site locations in the Livermore Valley, and at Site $30\left(0\right.$ are collected on $5.2 \times 10 \mathrm{~m}^{2} \mathrm{~m}^{2}$ Whatman filters using high-volume samples with average flow rates of $706 !$ / min. These flow rates are verified at month!y intervals with a portable field-calibration unit. If a high-volume air sampler fails, it is repaired and then calibrated with a spirometer that was itself calibrated using an immersion unit certified by the National Bureau of 5tandards (NBS).

The remaining off-site samples in the Livermore Valley are collected on $7.5 \times 10^{3} \mathrm{~m}^{2}$ Flanders F-700 glass-fiber filters at a flow rate of $80 \mathrm{~L} / \mathrm{min}$. The flow-rate indicators are generally calibrated annually.

\section{Tritiated Water}

Samples of tritiated-water vapor are collecied by drawing air through silica-gel-packed columns at flow rates of ahout $0.5 \mathrm{~L} / \mathrm{min}$. The average flow rate is colculated from the initial and final flow rates, which are measured with a rotoneter that is calibrated annually. Columns are exchanged biweekly.

\section{Identification}

\section{Particulates}

Particulate samplers run continunusly, and the filters are exchanged weekly. Each filter is identified by its location, the date on, the date off, the slapsed sampling time, and the flow rate. Filters are placed in glassine envelopes and are transported to the laboratory, where this information is transferred to log 
sheets and each filter sample is given a eerjal number that accompanies it throughout the analysis. Half of

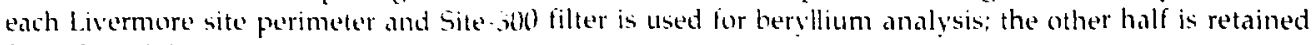
for radionactivity measurements.

\section{Tritiated Water}

Tritiated-water vapor samplers run continuously, and the silica-gel holders are exchanged biweekly: Each simple is ideritified by its location, the date on, the date off, the elapsed sampling time, and the flow rate. This information is transferred to log sheets in the laboratory and each sample is given a serial number that accompanies it throughout the analysis.

\section{Replication}

\section{Particulates}

A partictiate air sampler is operated in parallel with the permanent sampler at one of the six Livermore site perimeter locations. This parailel operation is continued for one month, the filters are exchanged weokly, and both filtors art submitted for analysis in the usual manner. Monthly rotation of the extra sampler among the six locations ensures the samplers are checked ammually. The replicate samples are then compared with respect to gross alpha and betw activities and to $23 \mathrm{Pu}$ content.

\section{Tritialed Water}

Parallel samples of tritiated-water vapor are collected at the Livermore site perimeter locations during alternate months from those in which particulate replicates are collected. The parallel sampler is operated at the perimeter locations at one-month intervals,

\section{Soil Sampling}

Soil samples are collected annually within the Livermore Valley and at Site 300 . Radiochemical analyses of these samples serve to document any changes that may have occurred during the year. Approximately 20 sampling sites within the Livermore Valley are chosen at random from a list of 125 locations; this list provides the data hase of various nuclides in the soil near the Livermore site. The same sampling sites are used each year at Site 300 to provide an ongoing comparison, with additional sampling sites added from time to time to expand coverage or to test specific hypotheses.

\section{Collection}

Sampling sites are selected in reasonably level areas that represent undisturbed soil. A 2-m square is marked off in each area, and an $8.25-\mathrm{cm}$-diam coring tool, designed at LLNL, is used to collect 5-cm-deep samples at the corners and center of the square.

\section{Identification}

Five samples of soil collected from each $2-\mathrm{m}$ square are composited in a plastic bag and identified by number. This number is entered in a loghook, together with the sampling data and a description of the sample location. The number is used to identify the sample throughout the laboratory aralyse: and in the Environmental Monitoring Annual Report. 


\section{Replication}

During each annual collection of soil samples, approximately $10 \%$ of the sites are sampled in duplicate. In duplicate collections, two adjacent cores, $5 \mathrm{~cm}$ deep, are taken from the corners and center of each $2-\mathrm{n}$ square. Separate composites of the five cores are then made, and the composite's are identified by' successive numbers.

\section{Water Sampling}

At quarterly intervals, water samples from surface and groundwater sources in the Livermore Valley and at Site 300 are analyzed for gross alpha and heta radioactivity and for tritium content. These analyses are performed to determine if detectable changes in radioactivity have occurred.

Once each year, groundwater samples from the vicinity of the Livermore Water Reclamation Plant (LWRP) are analyzed for tritium. These analyses are performed to determine the extent, if any, of tritium migration to the groundwater from LLNL's se'wage effluent.

\section{Collection}

Grab samples of surface sources such as ponds, creeks, and reservoirs are obtained with a tethered plastic pail. A $500-\mathrm{mL}$ sample is collected for tritium analysis in an argon-flushed glass container fitted with a ground-glass stopper. Samples for other analyses are collected in $500-\mathrm{mL}$ polyethylene bottles.

\section{Identification}

As samples are collected in the field, they are labeled with the sampling location and date. In the laboratory, each sample is assigned a number that accompanies it during analysis.

\section{Replication}

During each sample collection period, at least $10 \%$ of the water samples are duplicates.

\section{Sewage Sampling}

Sewage from the Livermore site is discharged into the City of Livermore's sanitary sewer system. Radioactive or otherwise hazardous liquid wastes are first treated to reduce concentration levels to within applicable standards before they are released into the sanitary sewer. Sewage samples are collected from the Livermore site effluent, the treated effluent, and from the digester sludge at the LWRP.

\section{Collection}

\section{Livermore Site Effluent}

A 24-h composite of Livermore site sewage effluent is collected daily by a peristaltic pump that functions for $9 \mathrm{~s}$ every $5 \mathrm{~min}$ to collect $13 \mathrm{~L}$. Aliquots of this composite are transferred to plastic bottles and are submitted for analysis. 


\section{LWRP Effluent}

Daily composites of treated effluent from the l.WRP are collected by l.WRP employedes. Aliquots of these composites are placed in $5(0)-\mathrm{ml}$ polycthylene bottles and are retained for weekly collection by L.I.NL..

\section{LWRP Digester Sludge}

Composites from both digesters at the LWRP are collected monthly: The composites consist of aliyuots taken three times a werk from the circulating stwage.

\section{Identification}

As cach sewage sample is collected in the field it is labeled with the sampling location and date of sampling. In the laboratory: ach samplo is assigned a number that acompanies it during analysis.

\section{Replication}

\section{Livermore Site Effluent}

Ono replicate sample af livermore site offluent is taken overy Wednesday and is analyzed for gross alphat gross beta, and tritium analysis.

\section{LWRP Effluent}

One replicate samplo of I.WRT effleent is haken every Wednestay and is analyzed for gross alpha, gross beta, and tritium.

\section{Vegetation Sampling}

At quarterly intervals, samples of vegetation (usually native grasses) are collected throughout the Livermore Valley; at Site 300, and at off-site locations near 5ite 300. After these samples are freeze-dried, the tritiun content of the recovered water is determined by liquid-scintillation counting.

\section{Collection}

Samples of segetation are routinely collected from the same locations each sampling period. Grass samples are pulled up or cut close to the ground, and any soil is discarded. The bulk volume of these samples is ustally between 0.5 and $1 \mathrm{~L}$. As each sample is collected, it is placed in a plastic bag and frozen in a dry-joe chest to minimize water loss on the bag's surface. Duplicate samples are collected at each location and are later transferred to a freezer in the laboratory.

\section{Identification}

Samples of vegetation collected in the field are labeled according to simple type and location. In the laboratory; each sample is assigned a number that accompanies it until the measurement is reported.

\section{Replication}

Two samples of vegetation are collected at bach location in case the first sample is lost during analysis or the measurement is in question. At least one set of each group of samples collected is analyzed in duplicate to furnish replicate data. 


\section{Milk Sampling}

Milk samples are obtained at monthly intervals, or when avalable, from four goat farms near l.l.N1. A portion of each milk sanple is freeze-dried, and the tritium content of the recosered witer is determined by liquid-scintillation counting. A 1 - L. sample is preserved with formaldehyde and then gammacounted in a Marinelli beaker.

\section{Air Analysis}

Environmental air samples are analyzed for gross alpha and beta activity, plutonium, uranium, gamma-emitting radionuclides, and beryllium (Be).

\section{Gross Alpha and Beta Counting}

After a 4-day delay to allow for decay of the radon-thoron daughters, all environmental radioactivity air filters are counted for alpha and beta activity: Counting is done in a Sharp gas proportional counter using 20-min counting periods. Normally, this counter is used only for environmental sanples to avoid possible contanination.

\section{Standards and Calibration}

Separate ${ }^{234} \mathrm{Pu}$ and "hi' $\mathrm{Sr}$ standards on 5-sni-diam stainless-steel planchels are used to determine alpha and beta counting officiencies, respectively. These standards are traceable to NBS or to equivalent certification sources. Counting-efficiency measurements are made with each set of filters counted, and a background count is taken at the beginning of each run and between each set of 10 samples. Records are kept of background and counting-efficiency variations in the Sharp counter.

\section{Gamma Spectrometry}

Monthly composites of filters from sampling stations along the Livermore site perimeter and at Site 300 are sealed in a $214-\mathrm{cm}^{3}$ aluminum can, and submitted for gamma analysis.

\section{Plutonium and Uranium}

Monthly composites of air filters are ashed and then dissolved in a mixture of nitric acid $\left(\mathrm{HNO}_{3}\right)$ and hydrochloric $(\mathrm{HCl})$ and/or hydrofluoric acid (HF). Plutonium and uranium are then separated by an ion. exchange process. Plutonium is further purified by ion exchange, electroplated onto a stainless-steel disk, and submitted for alpha spectrometry. Uranium is further purified by ion exchange and submitted for analysis by mass spectrometry.

\section{Beryllium}

Every month, half of each weekly Livermore site perimeter and Site-300 paper air filter is composited by sampling location. Two paper filters at a time are wet-ashed with a mixture of $80 \% \mathrm{HNO}_{1}$ and $20 \%$ perchloric acid $\left(\mathrm{HClO}_{4}\right)$. The solutions are then evaporated to a few milliliters, taking care to prevent the samples from baking dry. After the samples are diluted with water, they are filtered, any residusis are discarted, and the filtrates are diluted to $100 \mathrm{~mL}$ with deionized water. 
Quantefication in dome hy atumic absorption spectrophotometry with electrothermal atomization. (Guality control includes a redgent blank with blank filters, a blank spiked with zoo ng of Be, and several s.amplem are upiked with esecentially carrier-tree 'Bes.

Standard of 1 . 2. and $5 \mu \mathrm{g} / \mathrm{l}$. are prepared by diluting an intermediate $1-\mathrm{ppm}$ stock solution obtained trom an NBS traceable $100(1)$ prom stock dilution. The dilutent in all cases is $1 \% \mathrm{HNO}_{3}$ in water.

\section{Water Analysis}

Environmental water samples are analyzed for gross alpha and beta activily, tritium, and beryllium.

\section{Gross Alpha and Beta Activity}

A 1011 - ml. sample or less, depending on the solid content, is digested with a mixture of $80 \% \mathrm{HNO}_{3}$

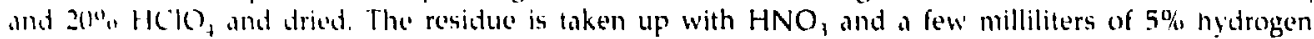
peroxide $\left(H_{2}()_{2}\right)$. The solution is evaporated to aboui $5 \mathrm{ml}$. and transforred to a 5 -cm-diam serrated, stainless-steel planchet. Aiter the planchet is tried and flamed, the sample is counted for $30 \mathrm{~min}$ in a Sharp $31 / 4$-in. proportional counter. A blank is processed with each set of samples.

\section{Standards and Calibration}

The : "Pu and "Sr standards are used with every sample set. (See similar entry below under "Soil Analyis.") Background measurements are made between every ten sample-counting measurements.

\section{Tritium}

low-level samples are electrolytically enriched and then counted by liquid-scintillation spectrometry. Each counting set incluctes a total of eight standards to establish quench corrections and eight blanks to tetermine background.

\section{Beryllium}

A $10(1)-\mathrm{mL}$. sample is digested with $\mathrm{HNO}_{3}$. The residue is diluted to $100 \mathrm{~mL}$ with deionized water, and the analysis is completed using atomic absorption spectrophotometry, as described for air analysis.

\section{Sewage Analysis}

Sewage samples are analyzed for gross alpha and beta activities, tritium, plutonium, cesium, and selected metal ions. All sewage samples except those to be analyzed for tritium are wet-digested with a mixture of $20 \% \mathrm{HClO}_{4}$ and $80 \% \mathrm{HNO}_{3}$. Those sewage samples to be analyzed for tritium are distilled to reduce quenching before counting.

\section{Gross Alpha and Beta Radioactivity}

Ahout $25 \mathrm{~mL}$ of an $80 / 20 \%$ mixture of $\mathrm{HNO}_{1}$ and $\mathrm{HClO}_{4}$ is added to an aliquot ( $500 \mathrm{~mL}$ if on site; 100 $\mathrm{mL}$. if from the LWR P), anct the mixture is heated to dryness on a hotplate. The residue is taken up in $10 \mathrm{ml}$. of $\mathrm{HNO}_{1}$ and $5 \mathrm{~mL}$ of $5 \% \mathrm{H}_{2} \mathrm{O}_{2}$. The volume is reduced to 3 to $5 \mathrm{~mL}$ on a hotplate, transferred to 5-cm-diam planchets, and counted. 


\section{Tritium}

A 5-mL aliquot of sewage sample is added to $15 \mathrm{ml}$. of Packard Instagel in a 25-ml. screw-cap polyethytene bottle. Then, $15 \mathrm{~mL}$ of Instagel is used to prepare a background for the sample, and both the sample and the background are placed in the refrigerated detection chamber of the Packard scintillation counter for a 1 -hr temperature equilibration prior to counting. Each is counted for $100 \mathrm{~min}$.

\section{Plutonium}

Plutonium is separated by co-precipitation with manganese dioxide $\left(\mathrm{MnO}_{2}\right)$. The manganese dioxide is then ashed and dissolved in $\mathrm{HNO}_{1}$ and $\mathrm{H}_{2} \mathrm{O}_{2}$. Plutonium is purified by ion exchange, electroplated onto a stainless-steel disk, and submitted for alpha spectrometry:

\section{Cesium}

Cesium is separated by ion exchange with amnonium molybdophosphote (AMP). The AMP iryshals are transferred to a counting wal with concentrated HCI, which is then submitted for gamma spectrometry:

\section{Metals}

Monthly composites of Livermore site sewage effluent are analyaed for cadmiun, chromiun, copper, iron, least, nickel, silver, aluminum, beryllium, and zinc.

$A$ composite is prepared by combining daily samples of $500 \mathrm{~mL}$. $\mathrm{HNO}_{1}(80 \%)$ and $\mathrm{HClO}_{4}(20 \%)$ are added to the first 500-ml. daily sample of the month, and the mixture is reduced in volume to ahout $100 \mathrm{~mL}$. Each subsequent day, the daily sample is added and the total volume is reduced to ahout $100 \mathrm{~mL}$. After the last $500 \mathrm{~mL}$. from the last day is added, the combined volume is reduced to about $50 \mathrm{ml}$. When cool, about $50 \mathrm{~mL}$ of deionized water is added, and the liquid is filtered through No. 40 Whatman paper. The paper is placed in a platinum crucible and digested with about $5 \mathrm{~mL}$ of HF, $16 \mathrm{~mL}$ of $\mathrm{HNO}_{3}$, and $4 \mathrm{~mL}$ of $\mathrm{HClO}_{+}$to a residue of about 4 to $5 \mathrm{~mL}$. Water is adted and the liquid is refiltered; the residue is discarded. The filtrates are combined, transferred to a $100-\mathrm{mL}$ volumetric flask, and brought to volume with deionized water. The metal content is determined with a Perkin-Elmer Model 5000 atomic-absorption spectrophotometer. The required siandards are prepared by diluting of a 1000 -ppm, NBS-traceable stock solution.

\section{Soil Analysis}

Soil samples are analyzed for gamma-emitting radionuclides, plutonium, and uranium.

\section{Gamma}

The soils are dried at $110^{\circ} \mathrm{C}$ for a minimum of 2 days, pulverized, passed through a 32-mesh sieve, blented, sealed in a $238-\mathrm{cm}^{3}$ aluminum can, and submitted for gamma spectrometry.

\section{Plutonium}

The soil is leached by heating for $4 \mathrm{~h}$ with a mixture of concentrated $\mathrm{HNO}_{7}$ and $\mathrm{HCl}$. The plutonium is then separated anst purified by ion exchange and electroplating. 


\section{Vegetation Analysis}

Vegetation samples are prepared for tritium by freeze-drying. The resultant water is analyzed for tritium by either liquid-scintillation spectrometry or gas proportional counting.

\section{Milk Analysis}

Milk samples are prepared hy freeze-drying. The resultant water is analyzed for tritium by liquidscintillation spectrometry. Milk samples are also analyzed by gamma spectrometry, consisting of a direct count of $938 \mathrm{~mL}$ of milk preserved with $20 \mathrm{~mL}$ of formaldehyde is placed in a Marinelli beaker.

\section{Wine Analysis}

Wine samples are analyzed for tritium by combustion in a Peterson furnace, which catalyzes the wine to $\mathrm{CO}_{2}$ and $\mathrm{H}_{2} \mathrm{O}$. The resultant water is then analyzed by gas proportional counting.

\section{Honey Analysis}

Huncy is analyzed for tritium by digesting the samples in a Parr Bomb followed by gas proportional counting. 
Appendix E. Discharge Limits

to the Sanitary Sewer System of the City of Livermore 
Sections 13.32.16, 13.32.08, 13.32.09, 13.32.100, and 13.32.110, of the City of Livermore Municipal Code (1983) state the discharge limits for Livermore's sanitary sewer system. These sections are reprinted below.

\section{Section 13.32.06 General Discharge Prohibitions.}

No person shall contribute or cause to be contributed, directly or indirectly, any pollutant or wastewater that will interfere with the operation or performance of the publically-owned treatment works (POTW). These general prohibitions apply to all such users of the POTW whether or not the user is subject to national categorical pretreatment standards or any other national, state, or local pretreatment standarts or requirements. A user may not contribute the following substances to the POTW:

(a) Any liquids, solids, or gases that by reason of their nature or quantity are, or may be, sufficient either alone or by interaction with other substances to cause fire or explosion or be injurious in any other way to the POTW or to the operation of the POTW. At no time, shall two successive readings on an explosion hazard meter, at the point of discharge into the system (or at any point in the system) be more than five percent $(5 \%)$ nor any single reading over ten percest $(10 \%)$ of the lower explosive limit (LEL) of the meter. Prohibited materials include, but are not linited to, gasoline, kerosene, naphtha, benzene, toluene, vylene, ethers, alcohols, ketones, aldehydes, peroxides, chlorates, perchlorates, bromates, carbides, hydrides, and sulfides and any other substances that the city, the state or the EPA has notified the user is a fire hazard or a $h$ zard to the system.

(b) Solid or viscous substances that may cause obstruction to the flow in a sewer or other interference with the operation of the wastewater treatment facilities such as, but not limited to: grease, garbage with particles greater than one-half inch $\left(1 / 2^{\prime \prime}\right)$ in any dimension, animal guts or tissues, paunch manure, bones, hair, hides or fleshings, entrails, whole blood, feathers, ashes, cinders, sand, spent line, stone or marblo tust, motal, glass, straw, shavings, grass clippings, rags, spent grains, spent hops, waste paper, wood, plastics, gas, tar, asphalt residues, residues from refining, or processing of fuel or lubricating oil, mud, or glass grinding or polishing wastes.

Specifically excluded from the sewers are waste products resulting from the handling, storage and sale of fruits and vegetables from other than retail produce establishments, or other foods not intended primarily for immediate consumption.

(c) Any wastewater having a pH less than 6.8 or greater than 8.5 , unless a city permit is obtained. Wastewater having any other corrosive property capable of causing damage or hazard to structures, equipment, and/or personnel of the POTW is also prohibited.

(d) Any wastewater containing toxic pollutants in sufficient quantity, either singly or by interaction with other pollutants, to injure or interfere with any wastewater treatment process, consititute a hazard to humans or animals, create a toxic effect in the receiving waters of the POTW, or to exceed the limitation set forth in the categorical pretreatment standard. A toxic pollutant shall include, but not be limited to any pollutant identified pursuant to Section 307(a) of the Act.

(e) Any noxious or malodorous liquids, gases, or solids, which either singly or by interaction with other wastes are sufficient to create a public nuisance or hazard to life or are sufficient to prevent entry into the sewers for maintenance and repair.

(f) Any substance that may cause the POTWs effluent or any other product of the POTW such as residues, sludges, scums, or gases, to be unsuitable for reclamation and reuse or to interfere with the reclamation process. In no case, shall a substance discharged to the POTW cause the POTW to be in noncompliance with sludge use or disposal criteria, guidelines or regulations developed under Section 405 of the Act, any criteria, guidelines, or regulations affecting sludge use or disposal developed pursuant to the Solid Waste Disposal Act, the Clean Air Act, the Toxic Substances Control Act, or state criteria applicable to the sludge management method being used.

(g) Any waters or wastes that contain more than $100 \mathrm{mg} / \mathrm{L}$ of freon extractible fat, oil, or grease.

(h) Any substance that will cause the POTW to violate its NPDES Permit or the receiving water quality standards.

(i) Any wastewater with objectionable color not removed in the treatment process, such as, but not limited to, dye wastes and vegetable tanning solutions. 
(i) Ans wantewater hasing a temperature that will inhibit biologital activity in the POTW treatment plant resulting in interference, but in no case wastewater with a temperature at the introduction inte the rotil which ascoeds $40^{\circ} \mathrm{C}\left(114^{\circ} \mathrm{H}\right)$.

(k) Any pollutants, including ovgen demanding pollutants (BOD, che) released at a Bow rate and/or polluant concentratem that a user hnows or has reason to know will cause interference to the POTW:

(1) Any Wastewater containing any rationative wastes or isotopes of such half-life or concontration as may exced the limits established by the state or federal regulatery agency applicable to the PoTw' user.

(m) iny wastewater that cause's a hacard to human life or creates a public nuisance.

(n) Any waters or wastes containing total dissolved solids increment greater than $325 \mathrm{mg} / \mathrm{l}$. nor chloride incerment grester than $75 \mathrm{mg} / \mathrm{l}$, increase during a single cycle use of the water supply: unless a aly permit is obtained te soced this limit.

(1) Any water or wastes having a BOD greater than 300 (the average BOD for residential users), unless a city permit is obtained.

(p) Any waters or wastes containing more than $300 \mathrm{mg} / \mathrm{L}$ of suspended solids (the average st,ipended solids for residential users). unless a city permit is obonined.

When the Staperintendent determines that a user(s) is contributing wo the PoTW' any of the aboveenumerales substances in such amounis as to interfere with the operation of the POTW, the Superintendent shall (1) advise the user(s) of the impat of the contribution on the POTW, and (2) develup eflluent limitations for such user(s) to correst the interference with the P(O)T:

\section{Section 13.32.08 Federal Categorical Pretreatment Standards.}

Upon the promulgation af the Federal Categorical Pretreatment Standards for a particular industrial subcategory, the federal Standard. if more stringent than limitations improsed under this article for sources in that subcategory, shall immedialely supersede the limitations imposed under this article. The Superinfendent shall notify all affected usters of the applicable reporting reguirements under $40 \mathrm{CFR}$, Section 4013.12 .

\section{Section 13.32.09 Modification of Federal Categorical Pretreatment Standards.}

Where the city's wastewater treatment system achieves consistent removal of pollutants limited by Federal Pretrentment Standards, the city may apply to the state/EPA for modification of specific limits in the Federal Pretreatment Standards. "Consistent Removal" shall mean reduction in the amount of pollutant or alteration of the nature of the pollutant, by the wastewater treatment system, to the less toxic or harmless state, in the effluent that is achieved by the system in 95\% of the samples taken when measured according to the procedures set forth in Section 403.7 (c) (2) of (Title 40 of the Code of Federal Regulations, Part 40.3)- "General Pretreatment Regulations for Existing and New Sources of Pollution" promulgated pursuant to the Act. The city may then modify pollutant discharge limits in the Federal Pretreatment randards if the requirements contained in 40 CFR, Part 403, Section 403.7, are fulfilled and prior approvial from state/EPA is obtained.

\section{Section 13.32.100 Specific Pollutant Limitations.}

No person shall discharge wastewater containing in excess of:

\begin{tabular}{|c|c|}
\hline 0.1 & mg/l a cosenit \\
\hline 1.2 & $\mathrm{mg} / \mathrm{L}$ cadmium \\
\hline 2.0 & mg/l. copper \\
\hline 1,0 & mg/l. cyonicte \\
\hline & $m g / l$ leat \\
\hline 0 & $\mathrm{mg} / \mathrm{l}$ mercury \\
\hline & my/l. nickel \\
\hline
\end{tabular}



$0.2 \mathrm{mg} / \mathrm{L}$ silver
$1.0 \mathrm{mg} / \mathrm{L}$ total chromium
$3.0 \mathrm{mg} / \mathrm{L}$ zinc
$0.02 \mathrm{mg} / \mathrm{L}$ total identifiable chlorinated hydrocarbons
$1.0 \mathrm{mg} / \mathrm{L}$ pheonolic compounds
$0.01 \mathrm{mg} / \mathrm{L}$ polychlorinated biphenyls

\section{Section 13.32.110 State Requirements.}

State requirements and limitations on discharges shall apply in any case where they are more stringent than Federal requirements and limitations or those in this article. 
Appendix F. Methods of Dose Calculations 
The radiological impat to ihe public from operations at Lawience Livermore National Laborators (1.1.N1.) in assessed in acortance with applicable Department of Energy (DOE) orders. Based on releases of rationtivity to the environment and measurements of environmental media, fo ir potential dos:es are calculated: I.l.NL perimeter nearest resident, point of mavimum exposure in an uncontrolled area, and the fopulation residing within an $80-\mathrm{km}$ ratius of the l.L.N1. The doses in this report may be compared to the radiation protection standards astablished by the DOE and other regulatory bodies (see Appendix C).

For the purposes of this report. doscs are reported in terms of "effective dose equivalent," which is defined as the sum of the dose from external radiation and the committed (50-y) effective dose equivalent from ingestion and inhalation during a $1-y$ period. This dose is a measure of the potential health effects from radiation exposure. It also acrounts for the radiation dose delivered to the hody from intakes of rationuclides with a long effective half life (i.e. radionuclides with long residency in the body). Thus, the "effective dose equivilent" incluties the total dose received over a 50-y period following a $1-y$ exposure. The effective dose equivalents if this report were calculated using the dosimetric parameters recommended by the International Commission on Radiological Protection in Publications 26 (1977) and 30 (148(1).

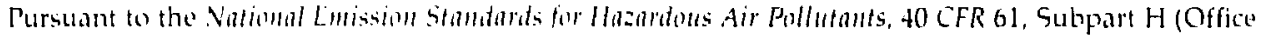

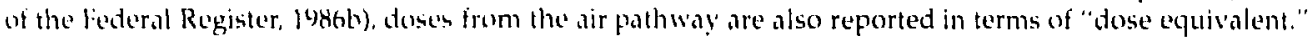
These dose's refer to a measure of radiation dose and are calculated based on the wholo boty/eritical organ concept of ICRP Publication Number 2. These doses were derived using the Clean Air Act Code, which contains models (AIRDOS-EPA and RADRISK) approved by the Environmental Protection Agency (EPA) for calculating atmospheric transport and exposure. Population exposure was converted to dose using dose' conversion facturs and weighting hators specified by the EPA.

\section{Radiological Dose Assessment Performed for 1987}

Bricfly described bolow are sich of the doses used to measure the radiological impact from LLNL during 1987.

1. External "fence-post"dose. The fence-post dose rate is a measure of the maximum external dose at locations of nearest uncontrolled putlic access. Dose rates from external penetrating radiations (primarily gamma rays and neutrons) are neasured using environmental dosimeters (thermoluminescence dosimeters and neutron detectors). The environmental dosimeters measure dose rates fron: all external radiation sources, including cosmic radiations, naturally occurring radioactivity in the environment, fallout from nuclear weapons testing, and any contribution from LLNL operations. Hence, these doses are not solely attributable to LLNL and in most instances are a measure of regional background. This is determined by comparing the perimete: measurements with those made at off-sile (Livermore Valley) locations. Morewer. ihese measurements are made at points of maximum exposure and assume an occupancy of $24 \mathrm{~h}$ per day: 305 day's per $y$. In actuality, no member of the public resides at these locations for extended periods of time, making these conservative estimates.

2. Ingestion dose. Potential doses from ingestion of locally produced foodstuff and surface water are based on actual measurements of radionticlide concentrations in the various media (determined by sampling). Conservative exposure data and current ICRP dosimetric factors are used to estimate doses to the individual. The following radionuclide exposure pathways are assessed by means of field measurements: tritium in water, tritium in milk, and tritium in vegetation (which includes the forage-cow-milk pathway).

3. Inhalation/submersion dose. Air pathway doses are calculated for each airborne radioactive dis. charge to the atmosphere. Inhalation/submersion doses are calculated at the Livermore site perimeter, nearest resident, and point of maximum off-site exposure. The amount of radioactivity released from the LLNL is usually too low to accurately measure radionuclide concentrations in ambient air and to detemine dose. Therefore, environmental transport and exposure pathway models are used to calculate potential closes resulting from effluent emissions (i.e., measurements made at the building stack). These doses are calculated by two methods to comply with both the newly adopted DOE standards (equivalent to current ICRP recommendations) and the National [mission Staldards for Hazardous Air Pollutalts, 40 CFR 61. Subpart $H$ (Office of the Federal Register, 1986b). 
Dose alculations were made using a continuous-point-source computer code based on the Caussian plume niodel (Peterson el al., 197h). This code provides ratios of concentration to release rate $(\chi / Q)$ through sivteen $22.5^{\circ}$ compass sectors and distances from 0.1 to $100 \mathrm{~km}$ from potential release points. The average annual $\chi / Q$ vilues have been calculated using local meteorological data. These data were obtained trom sensors on the LLNL meteorological tower from a height of $40 \mathrm{~m}$. From records of these data, wind speed, wird direction, and atmospheric stability estimates were tabulated at one-quarter-hour intervals over the calendar year. Digitized meteorological data became available at Site 300 in May of 1986, and were used to perform dispersion calculations for the advanced test accelerator emissions.

Variance in the horizontal wind ctirection was used to estimate Pasquill-Gifford stability categories based on the method siescribed by D. H. Slade (Slade, 1968). Lateral and vertical standard deviations $\sigma$, and $\sigma$, are entered in the computer code as functions of these stability categories and the respective distances. Bused on the annual effluent data (release rate $Q$ ) and the appropriate $\chi / Q$ values, the radionuclide concentrations at the site perimeter and the nearest resident were calculated. "Nearest resident" refers to the resident receiving the highest duse from each radioactivity release point, not necessarily the resident nearest to the site perimeter.

4. Maximully exposed individual dose. This dose represents the maximum credible dose to any "hypothetical"member of the general public. It inclucles contributions from all potential exposure pathways and is terived using the most conservative but realistic exposure data and assumptions. This hypothetical person is assumed to reside at the point of highest ground-level radionuclide air concentration continuously for $24 \mathrm{~h}$ per day, 365 days per year. During this occupancy period, a portion of this person's thet consists of locally protuced foodsiuffs and drinking water containing the highest measured radionudide concentration. Thus, this is not a dose actually received by any individual and should be viewed as a conservative estimate (i.e., over estimate) of the hiphest possible dose to any member of the public.

5. Collective population dose. The collective population dose is the dose for all individuals residing within an $80 \mathrm{~km}$ radius of LLNL. It is calculated by summing for each sector the average individual dose multiplied by the number of individuals residing in the sector. The collective population dose is referred to as the "collective effective dose equivalent" and is expressed in terms of person-rem.

The effective dose equivalents shown in this report have been calculated using models and methods consistent with the NRC Regulatory Guide 1.109, Calculation of Antunl Dose's to Man from Routine Releases of Re'actor Efflu'nt (U.S. Nuclear Regulatory Commission, 1977). The dose and dose-rate conversin factor used in these calculations were obtained from the committed dose equivalent tables for DOE dose calculations. These dose conversion factors are consistent with those specified in ICRP 30, Limits of Intakes of Rationuclite's by Worke's (International Commission on Radiological Protection, 1980). Examples of these calculations and assumptions are presented below.

\section{Annual Dose from Potable Water}

Assuming that all water sampled is available as drinking water, the annual whole-body dose for tritium has been calculated using the following equation:

$$
R_{\text {whole huds }}=C_{w} U_{w} D_{w} \text {. }
$$

where

$$
\begin{aligned}
C_{w}= & \text { concentration }(\mathrm{pCi} / \mathrm{L}) \\
U_{w}= & \text { intake rate }(\mathrm{L} / \mathrm{y})=730 \mathrm{~L} / \mathrm{y} \text { for maximum exposed individual, } \\
D_{w}= & \text { dose factor }(\mathrm{mrem} / \mathrm{pCi})=6.3 \times 10^{-8} \mathrm{mrem} / \mathrm{pCi} \text { for the whole-body inges- } \\
& \text { tion pathway for an adult, } \\
R_{\text {whwir twitv }}= & \text { effective dose equivalent in mrem from ingestion of } 730 \mathrm{~L} \text { of potable water } \\
& \text { with concentration } C_{w} .
\end{aligned}
$$




\section{Annual Dose from Forage-Cow-Milk Pathway for Tritium in Vegetation}

Assuming that all feed for the cattle was pasture grass, the effective dose equivalent per $\mu \mathrm{Ci} / \mathrm{mL}$ of tritiated watar (HTO) for the maximum exposed individual has been calculated using the following equation:

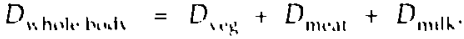

$$
\begin{aligned}
& D_{1, k} \text { (leaty vegetables) }=U_{1 \mathrm{~g}} \times C_{1 \mathrm{~m}} \times D_{\mathrm{m}}
\end{aligned}
$$

where

$$
\begin{aligned}
& U_{u, k}=\text { intake rate }(\mathrm{kg} / \mathrm{y})=64 \mathrm{~kg} / \mathrm{y} \text { for maximum-exposed individual, } \\
& C_{1 \ldots h}=\text { concentration }(\mu \mathrm{Ci} / \mathrm{kg})=10^{4} \frac{\mathrm{pCi} / \mathrm{kg}}{\mu \mathrm{Cl} / \mathrm{ml}} \times \mathrm{C}_{1 \ldots k} \mu \mathrm{Ci} / \mathrm{mL} \text { (measured). } \\
& D_{1: 1,}=\text { dose factor }(\mathrm{mrem} / \mathrm{pCi})=6.3 \times 10^{\times} \mathrm{mrem} / \mathrm{pCi} \text { for } \mathrm{H} \text { for the adult } \\
& \text { whole-body ingestion pathway, and } \\
& D_{\ldots \mathrm{g}}(\mathrm{mrem} / \mathrm{y} r)=0.40 \times 10^{-1} \mathrm{C}_{\mathrm{b}} \mu \mathrm{Ci} / \mathrm{mL} \text { (measured). }
\end{aligned}
$$

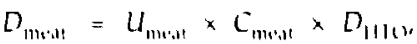

where

$$
\begin{aligned}
& U_{1 m+1}=110 \mathrm{~kg} / \mathrm{y} \\
& D_{111}=6.3 \times 10^{*} \text { nrem } / \mathrm{pCi} \text {, } \\
& \mathcal{C}_{m b i t}=\left(F_{1}\right)\left(Q_{1}\right)\left(C_{w, p}\right) \exp \left(-\lambda_{1} t_{n}\right) \\
& F_{1}=\text { fraction of taily intake of nuclide per } \mathrm{kg} \text { of animal/fish }(\mathrm{pCi} / \mathrm{kg} \text { in meat per } \\
& \mathrm{pCi} / \text { day ingested by the animal), days/kg. } \\
& Q_{1}=\text { amount of feed consumed }(\mathrm{kg} / \mathrm{day}) \text {, } \\
& C_{1+2}=\text { same as above. } \\
& \lambda_{t}=\text { radiological decay constant, day ! } \\
& \text { 1. = time between slaughter to consumption (days). } \\
& C_{\text {must }}=\left(1.2 \times 10^{2}-\frac{\mathrm{day}}{\mathrm{kg}}\right)\left(50 \frac{\mathrm{kg}}{\mathrm{day}}\right)\left(\mathrm{C}_{\mathrm{w}} \frac{\mu \mathrm{Ci}}{\mathrm{mL}}\right)\left(10^{4} \frac{\mathrm{pCi} / \mathrm{kg}}{\mu \mathrm{Ci} / \mathrm{mL}}\right) \\
& \times \exp \mid-1.5 \times 10+201)=0.6 \times 10^{4} \frac{\mathrm{pCi} / \mathrm{kg}}{\mu \mathrm{Ci} / \mathrm{mL}} \\
& \times C_{1} \frac{\mu \mathrm{Ci}}{\mathrm{mL}} \text { (measured), } \\
& D_{\text {muat }}(\mathrm{mrem} / \mathrm{y})=0.41 \times 10^{4} \times \mathrm{C}_{\mathrm{reg}} \mu \mathrm{Ci} / \mathrm{mL} \text { (measured). } \\
& D_{m, k}=U_{m 1 k} \times C_{m 1 k} \times D_{111,1}
\end{aligned}
$$


where

$$
\begin{aligned}
& U_{\text {nulk }}=310 \mathrm{I} / \mathrm{s} \\
& D_{1111}=6.3 \times 10 " \mathrm{mrem} / \mathrm{pCi} \text {. } \\
& C_{\text {milk }}=F_{1 n} U_{1} C_{\text {wn, }} \text { axp }\left(\lambda, t_{1}\right) \text {. } \\
& F_{m}=\text { fraction of daily intake of nutide per liter of milk }(\mu \mathrm{Ci} / \mathrm{l} \text {. in milk per } \\
& p C i / \text { day ingested by the animal), day/l., } \\
& \left.Q_{1}=\text { amount of feed consumed ( } \mathrm{kg} / \mathrm{day}\right) \text {, } \\
& C_{\text {an }}=\text { same as ahove. } \\
& \lambda_{1}=\text { radiological decory constant, thys ! } \\
& t_{1}=\text { transport tine from the beed to milk receptor. }
\end{aligned}
$$

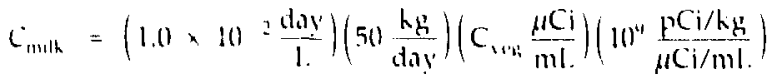

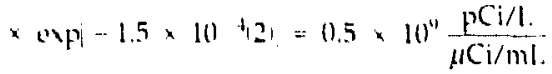

$$
\begin{aligned}
& \times L_{i, k} \frac{\mu C i}{m L} \text { (messured }
\end{aligned}
$$

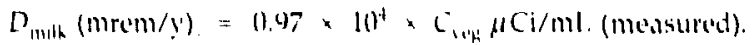

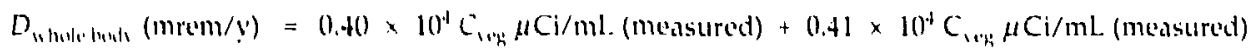

$$
\begin{aligned}
& +0.97 \times 10^{4} C_{1,4} \mu \mathrm{Ci} / \mathrm{mL} \text { (mensured) }=1.78 \times 10^{4} C_{1, \mathrm{~g}} \mu \mathrm{Ci} / \mathrm{ml} \text {. }
\end{aligned}
$$

\section{Inhalation/Submersion Dose}

To calculate the air pathway dose at the livermore site perimeter, to the nearest resident, and at the point of maximum exposure, a continuous-point-source computer code based on the Gaussian plume model was used.

A. Inhalation Dose ('H)

$$
D_{m a}=C \times U \times D .
$$

where

$$
\begin{aligned}
C= & \text { radionuclide concentration at the receptor, } \\
U= & \text { intake rate (the inhalation rate for adult maximally' exposect individual is } \\
& \left.8400 \mathrm{~m}^{1} / \mathrm{y}\right) \text {, and } \\
D= & \text { dose conversion factor for }{ }^{~} H ; D=9.45 \times 10^{\mathrm{N}} \mathrm{mrem} / \mathrm{pCi} \text {. }
\end{aligned}
$$

(The tritium dose conversion factor was obtained by multiplying the inhalation dose factor, 6,3 , $10^{\mathrm{k}} \mathrm{mrent} / \mathrm{pCi}$, by 1.5 to include alosorption through the skin.)

$$
c=3.17 \times 10^{-1}(\chi /())(Q) \text {. }
$$


where

$$
\begin{aligned}
\chi / Q & =\text { diffusion parameter }\left(\mathrm{s} / \mathrm{m}^{3}\right), \\
Q & =\text { release rate } \mathrm{Ci} / y, \\
3.17 \times 10^{+} & =1 \times 10^{12} \frac{\mathrm{PCi}}{\mathrm{Ci}} / 3.15 \times 10^{7} \frac{\mathrm{s}}{\mathrm{y}} .
\end{aligned}
$$

B. External Immersion Dose ( $\left({ }^{1 .} \mathrm{N}\right.$ and $\left.{ }^{15} \mathrm{O}\right)$

$$
D_{\max }=\mathcal{C} \times D R F
$$

where $D R F$, the dose-rate factor, is the external dose-equivalent rate per unit radionuclide concentration $\left(\frac{\mathrm{mrem} \times \mathrm{m}^{3}}{\mathrm{pCi}^{3} \times y^{\prime}}\right)$. For ${ }^{13 \mathrm{~N}}, D R F=5.22 \times 10^{3} \frac{\mathrm{mren} \times \mathrm{m}^{3}}{\mathrm{pCi} \times \mathrm{y}} ;$ for ${ }^{15} \mathrm{O}, D R F=5.25 \times 10 \frac{3 \mathrm{mrem} \times \mathrm{m}^{3}}{\mathrm{pCi} \times y}$,

\section{Annual Population Dose}

For population dose, the diffusion parameters and population figures for a sector $(i)$ within $80 \mathrm{~km}$ of LLNL were summed over all directions (n).

$$
\text { Dose (person-mrem) }=3.17 \times 10^{+}\left[\sum_{1}^{n}\left(x / Q_{1} P_{1}\right] Q \cup D\right. \text {. }
$$

where

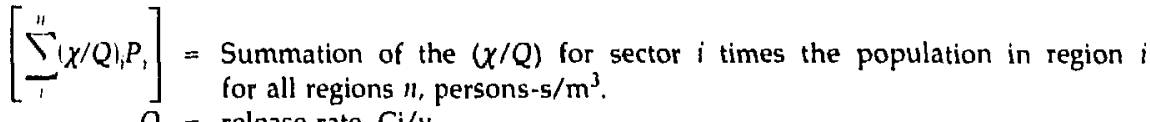

$$
\begin{aligned}
& Q=\text { release rate, } \mathrm{Ci} / \mathrm{y} \text {. } \\
& U \text { = inhalation rate, average individual (adult), } \\
& D=\text { dose factor, mrem } / \mathrm{pCi} \text {, } \\
& P_{1}=\text { the population of the } i \text { th sector. }
\end{aligned}
$$


Appendix G. Deviations from the Sampling Program 
Table G-1. Data for the following routinely scheduled samples were not reported for the reasons listed.

\begin{tabular}{|c|c|c|}
\hline \multirow[b]{2}{*}{ Station } & \multicolumn{2}{|c|}{ Air particulate monitoring } \\
\hline & Date & Reasun \\
\hline 1 & 1-13-87 & Air sampler malfunction \\
\hline 1 & $1-20-87$ & Air sampler malfunction \\
\hline 1 & $1-27-87$ & Air sampler malfunction \\
\hline 1 & $2-03-87$ & Air sampler malfunction \\
\hline 1 & $5-12-87$ & Air sampler malfunction \\
\hline 1 & $8-18-87$ & Air sampler malfunction \\
\hline 3 & $12-08-87$ & Air sampler malfunction \\
\hline 4 & $1-13-87$ & Air sampler malfunction \\
\hline 4 & $3-17-87$ & Air sampler malfunction \\
\hline 8 & $1-27.87$ & Air sampler malfunction \\
\hline 8 & $3-03-87$ & Air sampler malfunction \\
\hline 8 & $3-31-87$ & Air sampler malfunction \\
\hline $\mathbf{3}$ & $5-26-87$ & Air sampler malfunction \\
\hline 10 & $1-06-87$ & Air sampler malfunction \\
\hline 12 & $3-03-87$ & Air sampler malfunction \\
\hline 12 & $6-02-87$ & Air sampler malfunction \\
\hline 12 & $6-30-87$ & Air sampler malfunction \\
\hline 12 & $7-21-87$ & Air sampler malfunction \\
\hline 12 & $8-25-87$ & Air sampler malfunction \\
\hline 12 & $9-08-87$ & Air sampler malfunction \\
\hline 13 & $5-19-87$ & Air sampler malfunction \\
\hline 13 & 7-14-87 & Air sampler malfunction \\
\hline 13 & $7-21-87$ & Air sampler malfunction \\
\hline 13 & $9-01-87$ & Air sampler malfunction \\
\hline 15 & $3-17-87$ & Air sampler malfunction \\
\hline 15 & $4-28-87$ & Air sampler malfunction \\
\hline 17 & $2-24-87$ & Air sampler malfunction \\
\hline 17 & $3-24-87$ & Air sampler malfunction \\
\hline S300-1 & $9-01-87$ & Air sampler malfunction \\
\hline S300-1 & $10-20-87$ & Air sampler malfunction \\
\hline $5300-5$ & $1-27-87$ & Air sampler malfunction \\
\hline $5300-6$ & $6-30-87$ & Air sampler malfunction \\
\hline S300-7 & 1-13-87 & Air sampler malfunction \\
\hline S300-7 & $1-20-87$ & Air sampler malfunction \\
\hline S300-7 & $1 \cdot 27-87$ & Air sampler malfunction \\
\hline S300-9 & $7-7-87$ & Air sampler malfunction \\
\hline
\end{tabular}


Table G-1. (Continued).

\begin{tabular}{|c|c|c|}
\hline \multirow[b]{2}{*}{ Station } & \multicolumn{2}{|c|}{ Air tritium monitoring } \\
\hline & Date & Reason \\
\hline 1 & 1-15-87 & Air sampler malfunction \\
\hline 1 & $1-29-87$ & Air sampler malfunction \\
\hline 4 & $1-15-87$ & Air sampler malfunction \\
\hline 4 & $10-15-87$ & Air sampler malfunction \\
\hline 4 & $12-23-87$ & Flask broken \\
\hline 7 & $1-29-87$ & Air sampler malfunction \\
\hline 7 & $11-25-87$ & Air sampler malfunction \\
\hline 9 & 2-26-87 & Air sampler malfunction \\
\hline 9 & $12-10-87$ & Air sampler malfunction \\
\hline 12 & $6-04-87$ & Air sampler malfunction \\
\hline 13 & $2-26-87$ & Air sampler malfunction \\
\hline 13 & 3-12-87 & Air sampler malfunction \\
\hline 13 & 3-26-87 & Air sampler malfunction \\
\hline 13 & 9-03-87 & Air sampler malfunction \\
\hline 13 & $11-25-87$ & Air sampler malfunction \\
\hline 14 & $1-15-87$ & Air sampler malfunction \\
\hline 17 & 2-26-87 & Alr sampler malfunction \\
\hline $\mathrm{S1}$ & $12-10-87$ & Air sampler malfunction \\
\hline $\mathbf{S 2}$ & $7-30-87$ & Air sampler malfunction \\
\hline \multirow[t]{2}{*}{ S2 } & $10-29-87$ & Air sampler malfunction \\
\hline & \multicolumn{2}{|c|}{ Vegetation monitoring } \\
\hline Station & Date & Reason \\
\hline
\end{tabular}

\begin{tabular}{cll}
\hline 15 & Fourth quarter & No sample available \\
23 & Fourth quarter & Milk monitoring \\
Station & \multicolumn{2}{c}{ No sample available } \\
\cline { 2 - 3 } & \multicolumn{1}{c}{ Date } & Reason \\
\hline All & January & Goats not producing \\
5 & February & Goats not producing \\
5 & March & Goats not producing \\
5 & July & No milk available \\
5 & August & No milk available \\
$5,7,12$ & September & No milk available \\
All & October & Goats not producing \\
All & November & Goats not producing \\
& December & Goats not producing
\end{tabular}


Table G-1. (Continued).

\begin{tabular}{|c|c|c|}
\hline \multirow[b]{2}{*}{ Station } & \multicolumn{2}{|c|}{ Water monitoring } \\
\hline & Date & Reason \\
\hline 33 & Entire year & Pump not working \\
\hline 43 & January, February, March & $\begin{array}{l}\text { Swimming pool closed } \\
\text { for repairs }\end{array}$ \\
\hline $5300-7$ & Entìre year & $\begin{array}{l}\text { Permission to sample } \\
\text { denied by owners }\end{array}$ \\
\hline Stormwater 2 & December & Insufficient water \\
\hline \multirow[t]{2}{*}{ Storm water 4} & December & Insufficient water \\
\hline & \multicolumn{2}{|c|}{ Environmental radiation monitoring } \\
\hline Station & Date & Reason \\
\hline 01 & Fourth quarter & Missing \\
\hline 18 & First quarter & Missing \\
\hline 18 & Third quarter & Missing \\
\hline 20 & Fourth quarter & Missing \\
\hline 22 & Second quarter & Missing \\
\hline 30 & Second quarter & Missing \\
\hline 30 & Fourth quarter & Missing \\
\hline 37 & Fcurth quarter & Missing \\
\hline 38 & First quarter & Missing \\
\hline 38 & Second quarter & Missing \\
\hline 39 & First quarter & Missing \\
\hline 39 & Second quarter & Missing \\
\hline 40 & First quarter & Missing \\
\hline 40 & Second quarter & Missing \\
\hline $\mathbf{5 1}$ & Second quarter & Missing \\
\hline 68 & Third quarter & Missing \\
\hline 71 & First quarter & Missing \\
\hline 71 & Second quarter & Missing \\
\hline 77 & First quarter & Missing \\
\hline
\end{tabular}




\section{Appendix H. Quality Assurance Plan}




\section{Environmental Quality Verification Group Quality Assurance Plan}

R. C. Holland

September 18, 1987

C. E. DeGrange, Section Leader Guidance and Monitoring Section 
UCAR-10203

Environmental Quality Verification Group Quality Assurance Plan

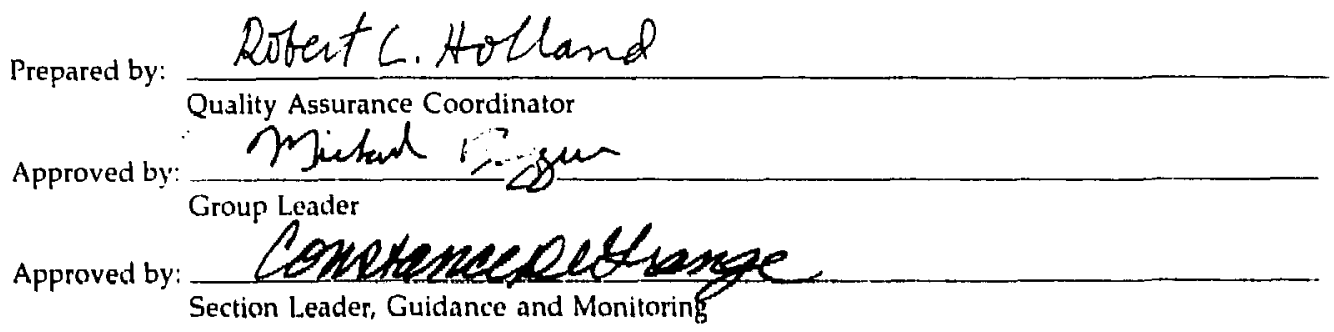

129 


\section{Contents}

Introduction

Quality Assurance Project Plan Locator Page

QAP-1 REV. 0 Organization

QAP-2 REV. 0 Quality Assurance Program

QAP-3 REV. 0 Design Control

QAP-4 REV. 0 Procurement Document Control

QAP-5 REV. 0 Instructions, Procedures, and Drawings

QAP-6 REV. 0 Document Control

Document Control .......... 15

QAP-7 REV. 0 Control of Purchased Items and Services _... 17

QAP-8 REV. 0 Identification and Control of Items . . . . . . 19

QAP-9 REV. 0 Control of Processes........ . 23

QAP-10 REV. 0 Inspection $\ldots \quad 25$

$\begin{array}{ll}\text { QAP-11 REV. } 0 \text { Test Control } & 27\end{array}$

QAP-12 REV. 0 Control of Measuring and Test Equipment 29

QAP-13 REV. 0 Handling, Storage, and Shipping 31

QAP-14 REV. 0 Inspection, Test, and Operating Status 33

QAP-15 REV. 0 Control of Nonconforming Items 35

QAP-16 REV. 0 Corrective Action $\quad 37$

QAP-17 REV. 0 Quality Assurance Records _ . 39

QAP-18 REV. 0 Audits 41 


\section{Introduction}

The Environmental Quality Verification Group (EQVG) is the organization within the Guidance and Monitoring Section of the Environmental Protection Department that is responsible for the monitoring of various environmental media in the vicinity of LLNL's Livermore Site and Site 300. This monitoring is carried out to meet the requirements of State and local regulatory agencies as well as Federal agencies (such as the Environmental Protection Agency (EPA) or the Department of Energy (DOE)).

DOE Draft Order 5480.XX of August 15, 1986 requires that DOE facilities have a quality assurance plan that addresses the 18 quality assurance criteria of ANS1/ASME NQA-1; the plan is to be written in the format of ANSI/ASME NQA-1.

This quality assurance plan was written to meet the requirements of DOE Draft Order 5480 .XX. Each of the 18 criteria has been assigned a Quality Assurance Procedure (QAP). The first section of each QAP states the requirement as taken from ANSI/ASME NQA-1. The goal of this quality assurance plan is to generate data that are precise, accurate, complete, representative, and comparable. The data can then be used as a basis for decision making about the monitoring program and the impacts of LLNL operations. To this end, the following goals are established for all environmental monitoring data:

Accuracy-Data shall be accurate to within $\pm 10 \%$ as determined by interlaboratory comparisons, or analysis of samples with known concentrations of the parameters of interest.

Precision-Data shall be precise to within $\pm 30 \%$ at the $95 \%$ confidence level as determined by the use of duplicate sampling techniques.

Completeness-Data capture shall be equal to or greater than $85 \%$ for each sampling media.

Representativeness-Sample collection points shall be chosen to assure that the collected samples are representative of the environmental medium sampled. Methods for choosirig sample collection points shall be addressed in the Environmental Surveillance Plan as required by DOE Draft Order 5480.XX.

Comparability-Data will be presented in all reports in the units required by DOE Draft Order $5480 . X X$ or by the appropriate regulatory agency to assure that data are comparable with data produced by other organizations. Wherever applicable, EPA standard methods will be used for sample collection and analysis.

In order to assure that this document also meets the quality assurance requirements of EPA regulations (such as the Comprehensive Environmental Response, Compensation, and $\mathrm{Li}$ ability Act (CERCLA) regulations), a Quality Assurance Project Plan Locator Page has been included that correlates the 16 EPA quality assurance criteria to the 18 ANSI quality assurance criteria. 


\section{Quality Assurance Project Plan Locator Page}

This page delineates which of the eighteen QAP's meet the sixteen Quality Assurance criteria specified by the Environmental Protection Agency for project plans stated in "Interim Guidelines and Specifications for Preparing Quality Assurance Project Plans" QAMS-005/80. This is done to avoid duplication of effort since the areas covered by both the EPA and ANSI documents overlap to a great extent.

Title Page

Title Page

Contents

Project Description

Contents

Project Organization and Responsibility

Introduction

QA Objectives for Measurement of Data

QAP-1

in Terms of Precision, Accuracy, Completeness,

Representativeness, and Comparability

Sampling Procedures

Sample Custody

Calibration Procedures and Frequency

Analytical Procedures

Data Reduction, Validation, and Reporting

Introduction

Internal Quality Control Checks and Frequency

QAP-5,6,9

QAP-8

QAP-12

QAP-9

QAP-2

QAP-2

Performance and System Audits and Frequency

QAP-18

Preventive Maintenance Procedures and Schedules

QAP-12

Specific Routine Procedures to be Used to Assess

Data Precision, Accuracy, and Completeness of

Specific Measurement Parameters Involved

QAP-2

Corrective Action

QAP-16

Quality Assurance Reports to Management

QAP-2 
Rev. 0

page 1 of 3 .

QAP-1

September 18, 1987

\section{Organization}

Prepared by:

Robert C. Holland

Approved by:

Quality Assurance Coordinator

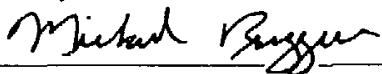

Leader Environmental Quality Verification Group

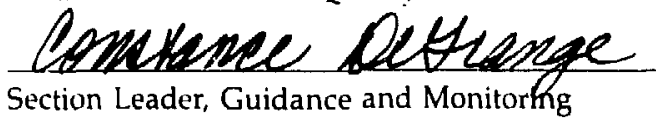

\section{Requirement}

ANSI/ASME NQA-1-1986: The organizational structure, functional responsibilities, levels of authority, and lines of communication for activities affecting quality shall be documented. Persons or organizations responsible for assuring that an appropriate quality as: surance program has been established and verifying that activities affecting quality have been correctly performed shall have sufficient authority, access to work areas, and organizational freedom to

(1) identify quality problems;

(2) initiate, recommend, or provide solutions to quality problems through designated channels;

(3) verify implementation of solutions; and

(4) assure that further processing, delivery, installation, or use is controlled until proper

disposition of a nonconformance, deficiency, or unsatisfactory condition has occurred.

Such persons or organizations shall have direct access to responsible management at a level where appropriate action can be effected. Such persons or organizations shall report to a management level such that required authority and organizational freedom are provided, including sufficient independence from cost and schedule considerations.

\section{Response}

This plan is designed to cover all EQVG activities that affect the quality of the environmental monitoring program. The plan addresses the 18 criteria of ANSI/ASME NQA-1-1986. Each member of EQVG is responsible for implementing all portions of this QA plan as it applies to his/her specific activities. The Quality Assurance Coordinator for EQVG will be responsible for assessing the implementation of this plan, while responsibilities for review and audit of this QA plan will reside with the LLNL Quality Assurance Office in order to assure that functional independence is maintained.

\section{A. Authorities and Responsibilities}

Section Leader, Guidance and Monitoring Section: Reiains ultimdte responsibility for the operation of the Environmental Quality Verification Group. Responsible for review and approval of all changes to the design of the monitoring program. 
Rev, 0

page 2 of -3.

September 18,1987

Group Leader: Responsible for the day-to-day operation of the EQVG. Responsible for review and approval of all changes to the design of the monitoring program, and all EQVG functional procedures. Responsible for review and approval of the annual environmental monitoring report.

Quality Assurance Coordinator: Responsible for review of all monitoring program design changes and all functional procedures. Responsible for compiling the annual environmental monitoring report. Responsible for periodically assessing the implementation of this QA Plan by the functional sections of the EQVG.

Scientific Support Personnel: Responsible for review and reporting of environmental monitoring data. Responsible for performing required dose assessments.

Technical Support Personnel: Responsible for sample collection, maintenance and calibration of sampling equipment, and maintenance and calibration of the meteorological sensors.

\section{B. Organizational Chart}

ENVIRONMENTAL PROTECTION DEPARTMENT

Department Head-Richard Ragaini

\section{GUIDANCE AND MONITORING SECTION}

Section Leader-Constance DeGrange

ENVIRONMENTAL QUALITY VERIFICATION GROUP

Group Leader (acting)-Michael Ruggieri

Quality Assurance Coordinator

Robert C. Holland

Technical Support

see page 3
Scientific Support

see page 3 
Rev. 0

page 3 of 3 .

September 18, 1987

\section{Scientific Support}

Dose Assessment

David D. Brekke
Data Analysis/Reporting

Robert C. Holland

David D. Brekke

Michael G. Brown

Tina M. Carlsen

\section{Technical Support}

Sample Collection

Marion Heaton

Chantel Aracne

Computations

Theresa Swatloski

6 technicians (part-time effort) 
Rev. 0

page 1 of 3.

QAP-2

September 18, 1987

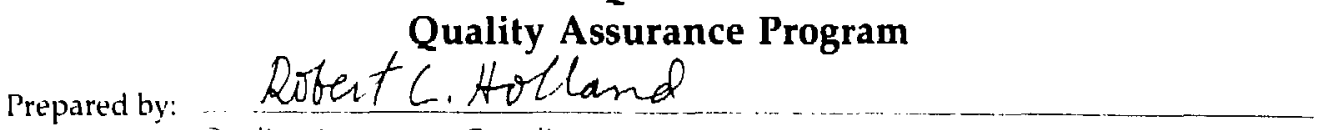

Quality Assuranco Courdinator

Approved by:

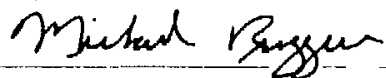

Group Leader

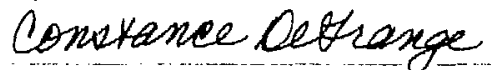

Siction lesader, Guidance and Momitoring

\section{Requirement}

ANSI/ASME NQA-1-1986: A documented quality assurance program shall be planned, implenented, and maintained in accordance with this Standard, or portions thereof. The program shall identify the activities and items to which it applies. The establishment of the program shall include consideration of the technical aspects of the activities affecting quality. The program shall provide control over activities affecting quality to an extent consistent with their importance. The program shall be established at the earliest time consistent with the schedule for accomplishing the activities.

The program shall provide for the planning and accomplishment of activities affecting quality under suitably controlled conditions. Controlled conditions include the use of appropriate equipment, suitable environmental conditions for accomplishing the activity, and assurance that prerequisites for the given activity have been satisfied. The program shall provide for any special controls, processes, test equipment, tools, and skills to attain the required quality and for the verification of quality:

The program shall provide for indoctrination and training, as necessary, of personnel performing activities affecting quality to assure that suitable proficiency is achieved and maintained.

Management of thost organizations implementing the quality assurance program, or portions thereof, shall regularly assess the adequacy of that part of the program for which they are re'sponsible and shall assure its effective implementation.

\section{Response}

This document details the Quality Assurance Program for the EQVG. This plan applies only to those aspects of EQVG's activities in operating the environmental monitoring program. This plan specifically does not apply to any research and development projects that may be undertaken by EQVG personmel.

\section{A. Training and Qualification of Personnel}

The required qualifications of each position within the monitoring program shall be specified (e.t., as in a job description). 
Rev. 0

page 2 of 3 .

September 18,1987

Training for EQVG personnel will follow the system being devised for Environmental Protection as a whole. l'ersonnel will be documented as qualified by the use of a Job Performance Checklist for each of the procedures they are required to perform. A system of periodic retraining, reexamining, recertifying, or reviewing performance will be established.

Training will be performed in order to assure that all personnel are aware of the nature and goals of the Quality Assurance Program.

Training may be performed by the Group Leader, Assistant Group Leader, members of scientific support, or by the technician supervisor. The trainer is responsible for documenting the training in accordance with EPD guidelines, and for forwarding the documentation to the EPD training coordinator for retention.

\section{B. Quality Control Samples}

Duplicate samples shall be taken according to the following schedule:

Air particulates: One replicate sampler is run in parallel with a normal sampler at the LLNL and Livermore Valley sites. A replicate simple is not currently taken at Situ 300 because all filters are composited for analyses.

Air tritium: One replicate sampler is run, in parallel with a normal sampler at the LLNL perimeter.

Surface water: For each sampling round, one replicate sample shall be taken for the Livermore Valley locations, and one replicate sample shall be taken for the Site 300 locations.

Groundwater: For each sampling round, two replicate samples shall be taken for the Livermore Valley groundwater sampling locations, and one replicate sample shall be taken for the Site 300 locations.

Soil: For each sampling round, two replicate samples shall be taken for the Livermore Valley locations, and one replicate sample shall be taken for the Site 300 locations.

Vegetation: A replicate sample shall be taken for each sampling location. One Livermore Valley and one Site 300 replicate sample shall be analyzed during each sampling round.

Milk: One replicate sample shall be taken quarterly.

Sewage: One replicate sample shall be taken each week.

During each sampling round, a field blank will be submitted for the following media: surface water (low tritium water), groundwater (low tritium water), milk (powdered milk reconstituted with low tritium water), sewage (low tritium water). Field blanks for the other media are considered impractical.

All laboratories performing analyses for the monitoring program shall be required to participate in measurement assurance programs. For radiological analyses, the EPA Environmental Radioactivity Laboratory Intercomparison Studies (Cross-check) Program, and 
Rev. 0

page 3 of 3.

September 18,1987

the DOE Environmental Measurements Laboratory (EML) Quality Assessment Program, are acceptable examples.

Periodically, the Quality Assurance Coordinator shall submit blind spikes to the analytical laboratories for analysis. The results of these analyses shall be reported to management as discussed below.

\section{Data Handling}

Responsibility for the review of data lies with Scientific Support Personnel. Data shall be reviewed in a timely fashion after receipt from the analytical group performing the analysis. This review will be accomplished in accordance with written procedures as specified in QAP-5. The reviewing person shall sign the chain-of-custody form accompanying the data upon receipt of the data. Data shall be plotted on control charts (or the equivalent) to provide easy identification of adverse trends. All data, and the associated control charts and chain-of-custody forms shall be filed in the Document Retention Center at the end of the reporting period (usually in April of the following year).

The previous year's environmental data shall be used to determine average valuer and 2-sigma error values for the control charts. If two consecutive data points fall outside the 2-sigma limits, or one data point falls outside the 3-sigma error values, these data vili be considered to be anomalous and an investigation will be initiated in accordance with QAP15 and QAP-16 to determine the cause of the anomalous data (whether it be due to sampling or analytical error, or possible sources for a high value that has been determined to be correct).

For all data calculations made by hand, at least $10 \%$ shall be independently verified by a knowledgeable individual who was not involved in performing the original calculation.

All manual data inputs shall be independently verified.

Replicate samples failing to meet the quality assurance goals listed in the introduction to this plan will be documented according to QAP-15 and the data dispositioned according to QAP-16.

\section{Internal Assessments}

Annually, the Quality Assurance Coordinator shall perform an assessment of the implementation of this QA Plan as discussed in QAP-18 of this Plan. This assessment shall be presented to management in the form of an annual quality assurance report. 
Prepared by:

\section{Design Control}

Approved by:

\section{Quality Assurance Coordinator}

\section{Mistad ressur \\ Group Leader}

Conutanee Detrayge

Section Lader, Guidance and Monitoring

\section{Requirement}

ANSI/ASME NQA-1-1986: The design shall be defined, controlled, and verified. Applicable design inputs shall be appropriately specified on a timely basis and correctly translated into design documents. Design interfaces shall be identified and controlled. Design adequacy shall be verified by persons other than those who designed the item. Design changes, including ficld changes, shall be governed by control measures commensurate with those applied to the original design.

\section{Response}

This requirement applies to the design of the monitoring program with respect to the following:

(1) Environmental media sampled.

(2) Frequency of sampling.

(3) Location of sampling stations.

(4) Analyses performed on samples.

(5) Equipment used for sampling.

The design of the monitoring program will be laid out initially in the Environmental Surveillance Plan as required by the final version of DOE Draft Order 5480.XX. Changes to any of the above-listed criteria (and thereby the Environmental Surveillance Plan) will be considered a design change, and will be controlled by this QA Plan.

All documents pertaining to the design of the monitoring program shall be prepared by personnel technically competent (as outlined in QAP-2, Section A) in this area. Prior to approval, the design shall be verified by competent personnel not directly involved in the development of the design document. This verification shall consist of one or more of the following: performance of design reviews, use of alternate calculations, or the performance of qualification tests. This design verification shall be documented. After verification, the document shall be reviewed and signed by the Section Leader-Guidance and Monitoring, the Group Leader, and the EQVG Quality Assurance Coordinator. 
Rev: 0

page 2 of 2 .

September 18, 1987

For the initial design (or justification of an existing design), a Design Package will be generated. This Design Package will contain the following documentation:

(1) A listing of all documents, texts, articles, etc. used as design inputs.

(2) The design document itself.

The Design Package will be placed in the appropriate file in the Document Retention Center as described in QAP-6.

For all design changes, a revised Design Package will be generated. The same verifications and approvals that were necessary for the original Design Package will be repeated for the revision. The revised Design Package will be placed in the appropriate Document Retention Center file. All superceded Design Packages will be retained in the historical files as described in QAP-6. 
Rev. 0

page 1 of 1

QAP-4

September 18, 1987

\title{
Procurement Document Control
}

I'repared by:

\author{
Dobert C. Hotland
}

Quality Assuranee Condinator

Approwed by:

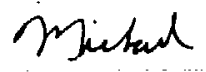

Group lidader

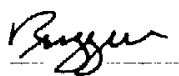

Conatance letrange

Sestion leader: Guidance and Monitoring

\section{Requirement}

ANSI/ASME NQA-1-1986: Applicable design bases and other requirements necessary to assure adequate quality shall be included or referenced in documents for procurement of items or services. To the extent necessary, procurement documents shall require suppliers to have a quality assurance program consistent with the applicable requirements of this standard.

\section{Response}

Standard LLNL procurement practices and documentation practices will be used for all purchases made by EQVG. EQVG will retain a listing of all major contracts or procurements executed for the monitoring program. This listing will be kept up to date, and retained in the Document Retention Center. The Group Leader will review all procurement documents to ensure that applicable portions of ANSI/ASME NQA-1-1986 (as determined by the Group Leader and the Quality Assurance Coordinator) are specified as requirements in the contract. The contract shall also contain provisions for inspection and audit by EQVG personnel. 
Rev. 0

page -1 of 2 .

QAP-5

September 18, 1987

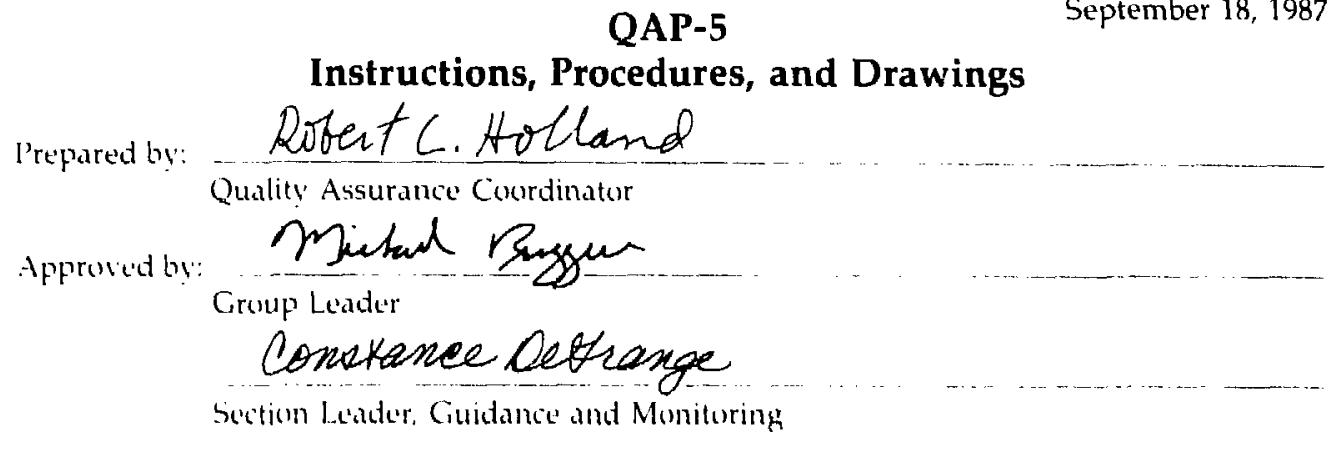

\section{Requirement}

ANSI/ASME NQA-1-1986: Activities affecting quality shall be prescribed by and perfurmed in accordance with documented instructions, procedures, or drawings of a type appropriate to the circumstances. These documents shall include or reference appropriate quantitative acesptance criteria for determining that prescribed activities have been satisfactorily accomplished.

\section{Response}

\section{A. Procedures}

EQVG procedures shall be written covering sample collection; packaging, shipment, and receipt of samples for off-site analysis; maintenance and calibration of sampling equipment; and reduction, evaluation, and reporting of data. Written procedures shall contain the following sections and headings:

Purpose: Briefly state the purpose and objective of the procedure.

Discussion: Discuss anything special about the nature of the procedure, background, etc. This section may also be used for discussing the scope of the procedure, if warranted.

References: Reference any procedures or documents directly applicable to the subject procedure and necessary for the successful completion of the tasks involved.

Definitions: Define any terms not in common use or that may be subject to multiple interpretations.

Equipment: List the equipment necessary to carry out the procedure.

Procedure: Provide a step-by-step description of the procedure, detailed enough to allow someone with an appropriate technical background to duplicate the procedure.

Documentation: List the appropriate forms that must be completed, disposition of those forms, length and method of storage, and any data transmission to be accomplished.

Acceptance Criteria: List appropriate qualitative or quantitative criteria for determining that prescribed activities have been satisfactorily accomplished. 
Rev. 0

page $\_2$ of 2 .

September 18,1987

\section{B. Computer Programs}

All computer programs used by EQVG shall be verified prior to initial use and after each modification. This shall be documented in a Design Package as described above in QAP-3. For programs generated in-huuse, the verification will consist of trial runs being performed and compared with independient hand calculations. For purchased programs, the manufacturer usually can provide adequate documentation of the program.

This information shall be placed in the Document Retention Center. 
Prepared by:

\section{Document Control}

Approved by

Quality Assurance Coordinator

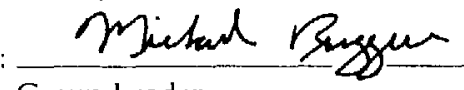

Group Leader

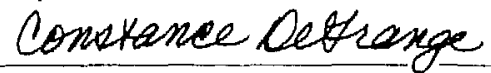

Section Leader, Guidance and Monitoring

\section{Requirement}

ANSI/ASME NQA-1-1986: The preparation, issuance, and change of documents that specify quality requirements or prescribe activities affecting quality shall be controlled to assure that correct documents are being employed. Such documents, including changes thereto, shall be reviewed for adequacy and approved for release by authorized personnel.

\section{Response}

Design documents shall be controlled by placing the revision number, date, and page number (as page ___ of ___ ) in the upper right hand corner of each page.

Design documents shall be filed in the Document Retention Center, and retained for the life of the facility. All historical revisions of design documents will be retained as above. The latest revision in the file shall reflect the actual current operating practices of the monitoring program.

Changes to design documents (other than inconsequential editorial changes) shall receive the same review as the original design document unless a different review process is specifically delineated. The only persons authorized to determine whether a change constitutes a minor change (and therefore does not require review) is the group leader.

All procedures necessary for the uperation of the monitoring program shall be prepared by personnel technically competent in the area covered by the procedure. Prior to issuance for use, all procedures shall be reviewed and signed by the group leader, and the EQVG Quality Assurance Coordinator.

Procedures shall be controlled by placing the revision number, date, and page number (as page _ of __ ) in the upper right hand corner of each page. All procedures will have the word 'controlled' stamped in red ink on each page of procedures issued for use by EQVG personnel. Any copy of a procedure not so stamped will be considered an unofficial copy and is not suitable for use by personnel in the field. The stamp may only be applied by the Quality Assurance Courdinator, or his designee.

The cover sheet of each procedure will indicate the date of the last review of the procedure, anc' the scheduled date of the next review. 
Rev: 0

page 2 of 2 .

September 18, 1987

Procedures will be reviewed annually by personnel familiar with the implementation of the procedure to determine if revision is necessary. If revision is necessary, it shal! be handled as described in this section. If it is determined that no revision is necessary, a new cover sheet for the procedure shall be issued indicating the revised review date.

Current procedures, and all historical procedures shall be filed in the Document Retention Center, and retained for a minimum of twenty years. The current revision in the file shall reflect the actual current operating practices of the monitoring program.

A log shall be kept in the Environmental Protection Department File that identifies those personnel who have controlled copies of the procedures. This log will be used to assure that all personnel have the most current revision of the procedures.

The Document Retention Center will also be used to house all other documents pertinent to the monitoring program, such as field log books, sample collection data sheets, and data sheets as received from the analytical laboratories. Final results from the monitoring program will be retained for the life of the facility. 
Rev. 0

page $\_1$ of 1 .

QAP-7

September 18,1987

\section{Control of Purchased Items and Services}

Prepared by:

Dobent C. Holland

Quality Assurance Coordinator

Approved by:

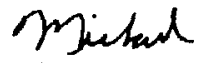

Group Leader

\section{Conatance Detiange}

Section Leader, Guidance and Monituring

\section{Requirement}

ANSI/ASME NQA-1-1986: The procurement of items and services shall be controlled to assure conformance with specified requirements. Such control shall provide for the following as appropriate: source evaluation and selection, evaluation of objective evidence of quality furnished by the supplier, source inspection, audit, and examination of items or services upon delivery or completion.

\section{Response}

Purchases for the EQVG will be controlled by LLNL's standard procurement practices. All documentation of this process will be filed in the appropriate file in the Document Retention Center.

A written procedure shall be developed which addresses specific areas to be considered during the procurement process. These specific areas shall include, at the minimum, 1) assessment of the proposed contractor's QA plan, 2) assessment of their past QA performance, 3) ability to do the work, and 4) cost factors. 
Rev. 0

page 1 of 4.

QAP-8

September 18,1987

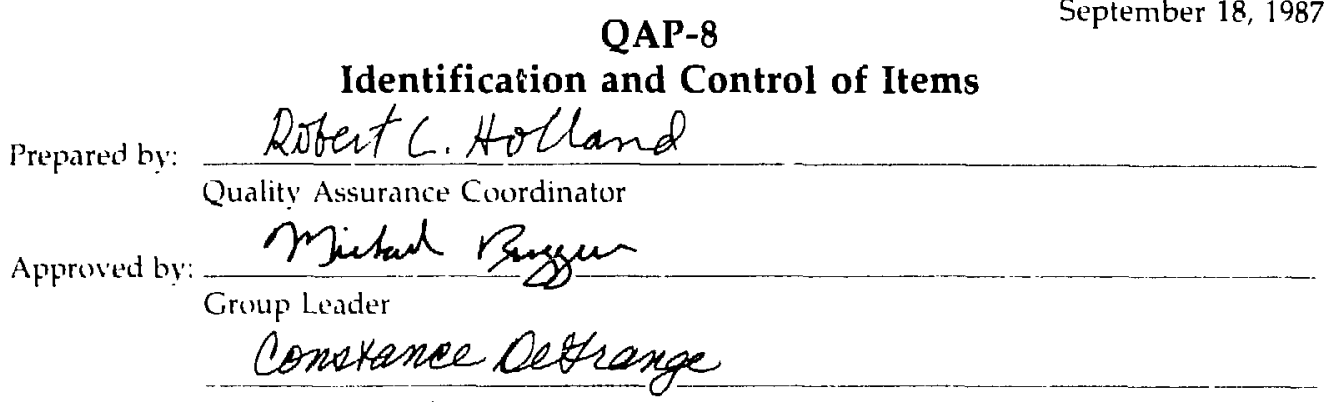

Section Leader, Guidance and Monitoring

\section{Requirement}

ANSI/ASME NQA-1-1986: Controls shall be established to assure that only correct and accepted items are used or installed. Identification shall be maintained on the items or in documents traceable to the items, or in a manner which assures that identification is established and maintained.

\section{Response}

\section{A. Equipment}

All equipment used for sampling shall be controlled by a unique identification number (serial numbers, LLNL inventury numbers, or EQVG assigned numbers are acceptable for this purpose). A list (or other tracking system) sha!l be maintained that indicates the present operating status of each piece of equipment, its current location, and its calibration status (date of last calibration and date of next scheduled calibration). This tracking system will be maintained by those members of the Technical Support Section responsible for maintenance, calibration, and placement of the equipment.

Consumable materials (such as air filters) shail be controlled by tracking the manufacturer's lot number and the samples they were used on.

\section{B. Sample Chain of Custody}

All samples shall have affixed to them a label containing at least the following information:

- Sampling location.

- Sample type.

- Date.

- Initials of the person collecting the sample.

Field Tracking Forms shall be completed in the field as the samples are collected. Specific field tracking forms will be included in the sampling procedures, and shail contain at least the following information: sample location, sample type, date collected, person collecting, and date 
Rev. 0

page 2 of 4 .

September 18, 1987

of submittal for analysis. The data from this form will be used to fill out a chain-of-custody form (Form QAP-8-1, or an equivalent form provided by a subcontractor laboratory) to be used during the remainder of the sample processing, up to and including the point of archiving of the data in the Document Retention Center. 


\section{Chain-of-Custody Record}

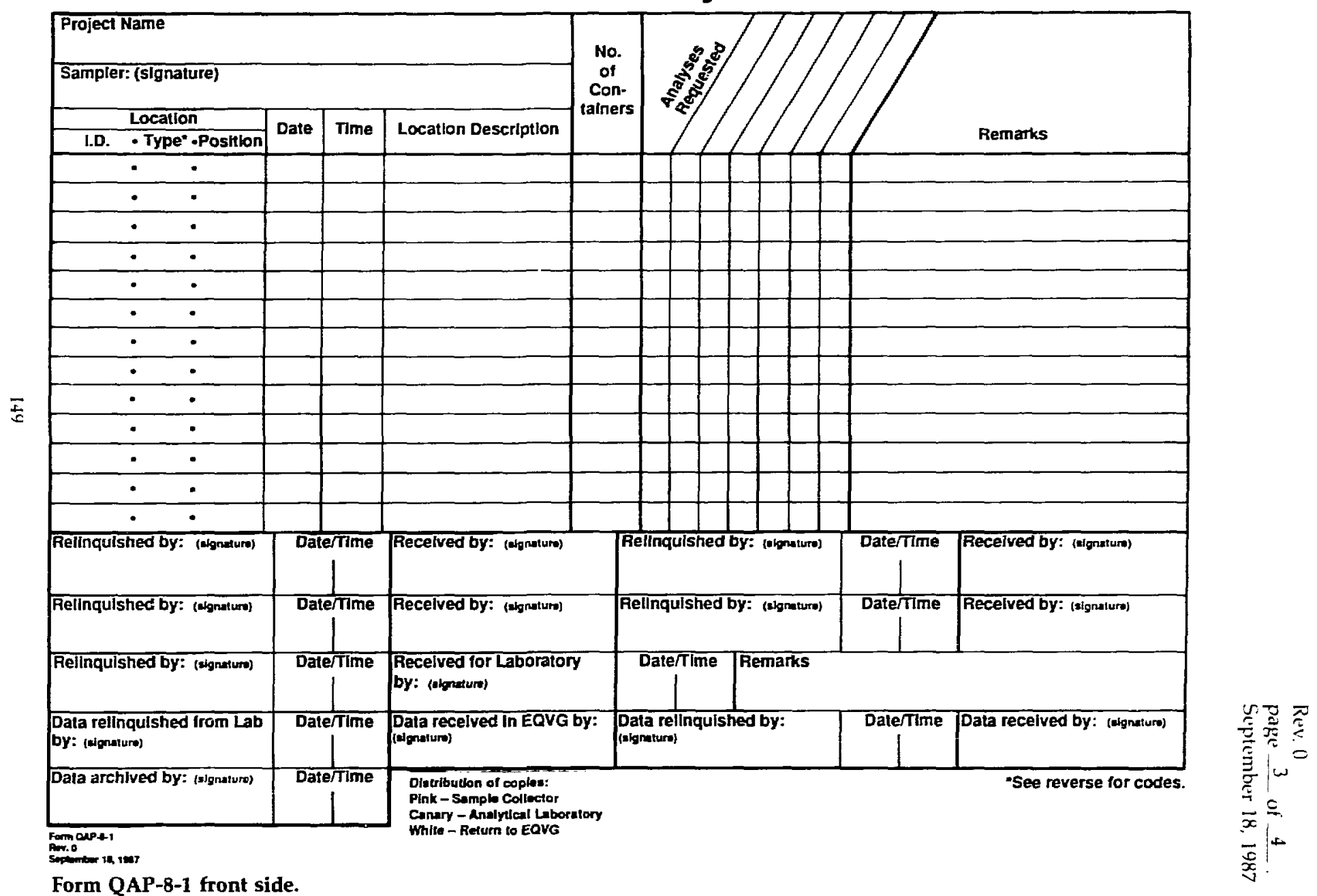


Groundwater Samples:

$$
\begin{aligned}
& \text { BC }=\text { Barcad } \\
& \text { BH }=\text { Borehole } \\
& \text { LY }=\text { Lysimeter } \\
& \text { NP }=\text { Neutron Probe } \\
& \text { MW = Monitoring Well } \\
& \text { SP }=\text { Spring }
\end{aligned}
$$

Non-Groundwater Samples:

$$
\begin{aligned}
& \text { AF }=\text { Air Filter } \\
& \text { AT }=\text { Air Tritium } \\
& \text { HY }=\text { Honey } \\
& \text { ML }=\text { Milk } \\
& \text { MS }=\text { Miscellaneous Samples } \\
& \text { OW }=\text { Other Water } \\
& \text { SN }=\text { Snoopy } \\
& \text { SO }=\text { Soil } \\
& \text { SW }=\text { Sewage } \\
& \text { TL }=\text { TLD } \\
& \text { VG }=\text { Vegetation } \\
& \text { WI }=\text { Wine }
\end{aligned}
$$


Rev. 0

page 1 of 1 .

QAP-9

September 18,1987

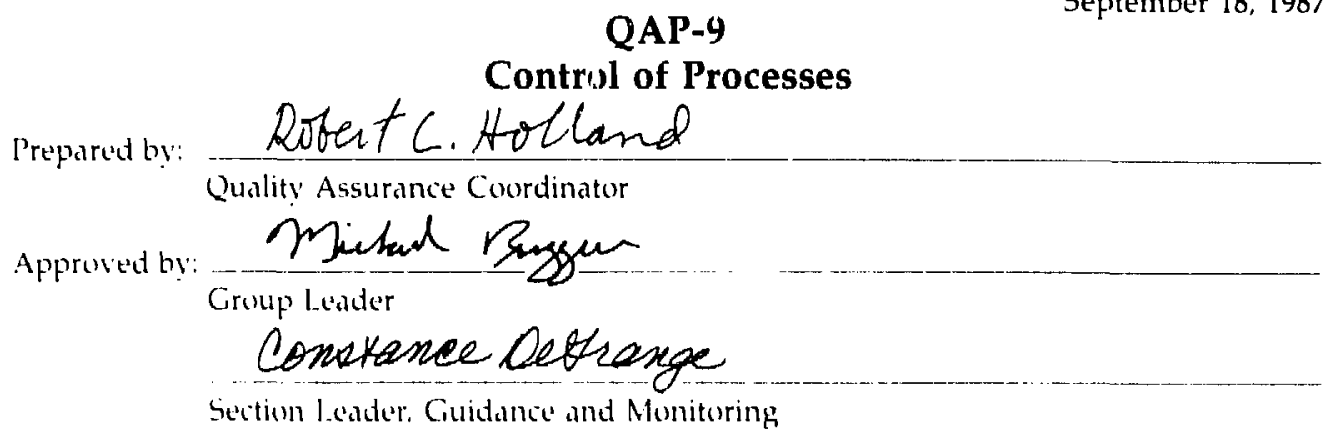

\section{Requirement}

ANSI/ASME NQA-1-1986: Processes affecting quality of items or services shall be controlled. Special processes that control or verify quality, such as those used in welding, heat treating, and nondestructive examination, shall be performed by qualified personnel using qualified procedures in accordance with specified requirements.

\section{Respoilse}

All aspects of sample processing shall be addressed by written procedures as described in QAP-5. Provisions shall be made for control of 'emergency' or 'one time' processes that are not covered by the normal procedures. Control of these processes will allow for professional judgement to be exercised, and will also allow for after-the-fact documentation to facilitate rapid response to unusual circumstances.

Personnel performing sample processing shall be qualified as outlined in QAP-2. However, to facilitate on-the-job training, it will be considered acceptable for unqualified personnel to perform sampling activities under the direct supervision of a qualified person. In such instances, both the trainee and the supervising person shall sign all required documentation. 
Prepared by: Robert C. Hothand

Inspection

Quality Assurance Coordinator

Approved by:

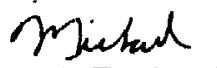

Croup Leater

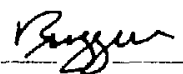

Conxtance Detraxge

Section Ledader, Guidance and Monituring

\section{Requirement}

ANSI/ASME NQA-1-1986: Inspections required to verify conformance of an item or activity to specified reçuirements shall be planned and executed. Characteristics to be inspected and inspection methods to be employed shall he specified. Inspection results shall be documented. Inspection for acceptance shall be performed by persons other than those who performed or directly supervised the work being inspected.

\section{Response}

This requirement is not considered applicable to the monitoring program. All items used for the sampling program are assured of suitability for the purpose by the procurement process and by initial testing. Inspection points during the sampling process are not considered feasible or necessary. 


\section{Test Control}

Prepared by:

Approved by:

Quality Assurance Coordinator

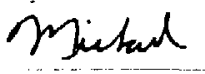

Crrup Leader

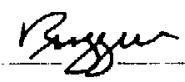

\section{Conatance Oeblaxpe}

Section Ladere. Guidance and Monitoring

\section{Requirement}

ANSI/ASME NQA-1-1986: Tests reyuired to verify conformance of an item to specified reyuirements and to demonstrate that items will perform satisfactorily in service shall be planned and executed. Characteristics to be tested and test methods to be employed shall be specified. Test results shall be documented and their conformance with acceptance criteria shall be evaluated.

Tests reyuired to collect data, such as for siting or design input, shall be planned, executed, documented, and evaluated.

\section{Response}

All new sampling equipment or procedures will be tested before being placed in service. The documentation from these tests will become part of the Design Package as described in QAP-3. The tests shall include, where practicable, the side-by-side testing of the new equipment or procedures with the old system. The new system shall be deemed acceptable when the results of the tests fall within plus or minus the 2-sigma error value of the old system, unless it can be shown through independent methods that the new system is more accurate than the old system, and similar results should not be expected. In this case, the test shall provide enough data to establish a new baseline and 2-sigma error factors. The new test shall provide enough data for this statistical evaluation to be made. 
Rev. 0

page 1 of 1 . 1 .

QAP-12

September 18, 1987

Control of Measuring and Test Equipment

Prepared by:

Robect C. Holland

Quality Assurance Coordinator

Approved by:

Mistan resgur

Group Leader

Conetance Detraxge

Section Leader, Guidance and Monitoring

\section{Requirement}

ANSI/ASME NQA-1-1986: Tools, gages, instruments, and other measuring and test equipment used for activities affecting quality shall be controlled and at specified periods calibrated and adjusted to maintain accuracy within necessary limits.

\section{Response}

All equipment shall be identified as described in QAP-8. Maintenance and calibration procedures shall be written and controlled as described in QAP-5 and QAP-6. Provisions shall be made in the calibration and operating procedures for acceptable ranges of operation, recalibration schedules, and treatment of 'out of control' equipment. Equipment determined to be 'out of control' shall be immediately removed from service.

All calibrations shall be traceable to National Bureau of Standards Standard Reference Materials (SRM's). The SRM to which the calibration is traceable shall be recorded on the calibration record and filed in the Document Retention Center. 


\title{
Handling, Storage, and Shipping
}

Prepared by:

\author{
Robert C. Holland
}

Quality Assurance Courdinatur

Approved by:

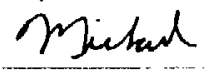

Group Leader

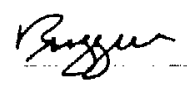

Constance Detiange

Section Leader. Cindince and Mlomitoring

\section{Requirement}

ANSI/ASME NQA-1-1986: Handling, storage, cleaning, packaging, shipping, and preservation of items shall be controlled to prevent damage or loss and to minimize deterioration.

\section{Response}

All sample collection procedures shall contain instructions on proper preservation and packaging of samples. These provisions shall be designed to maintain sample integrity under normal shipping and storage conditions.

Retention times shall be established for all sample types. These required retention times shall be specified in the contracts for all subcontractors handling the samples. 
Prepared by: \\ Inspection, Test, and Operating Status}

Approved by: ... Mictad renguen

Robert C. Holland

Quality Assurance Courdinator

Group Le'deder

Contrance Detrange

bection Leader, Guidance and Monitoring

\section{Requirement}

ANSI/ASME NQA-1-1986: The status of inspection and test activities shall be identified either on the items or in documents traceable to the items where it is necessary to assure that required inspections and tests are performed and to assure that items that have not passed the required inspections and tests are not inadvertently installed, used, or operated. Status shall be maintained through indicators, such as physical location and tags, markings, shop travelers, stamps, inspection records, or other suitable means. The authority for application and removal of tags, markings, labels, and stamps shall be specified. Status indicators shall also provide for indicating the operating status of systems and components of the nuclear facility, such as by tagging valves and switches, to prevent inadvertent operation.

\section{Response}

This section applies snly to the preoperational testing of equipment and procedures as outlined in QAP-11. Suci' e'uipment will clearly be marked 'under test,' and such procedures will be clearly marked 'dratt.' These markings shall not be removed until the Design Package has been approved by the Group Leader and the Quality Assurance Coordinator. 


\section{Control of Nonconforming Items}

Prepared by:

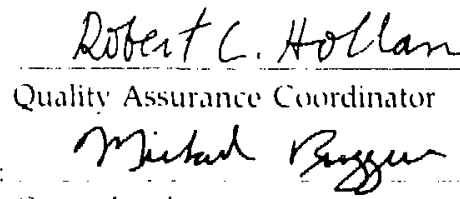

Cirup lesider

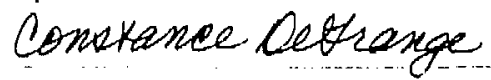

bection Leades. Gimdance and Monitoring

\section{Requirement}

ANSI/ASME NQA-1-1986: Items that do not conform to specified requirements shall be controlled to prevent inadvertent installation or use. Controis shall provide for identification, documentation, evaluation, segregation when practical, and disposition of nonconforming items, and for notification to affected organizations.

\section{Response}

Equipment ur materials that have been designated 'out of control' or have failed inspections or tests as described in QAP-11 or QAP-12 shall be physically separated. Provisions shall be made in the tracking system described in QAP-8 for identifying the operational or calibration status of all sampling exuipment.

Data that has been determined to be anomalous in accordance with QAP-2 (and its implementing procedures) shall also be considered nonconforming.

Deficiencies noted during assessments of EQVG operations by the Quality Assurance Coordinator shall be treated as nonconformances.

Nunconformances shall be brought to the attention of the Quality Assurance Coordinator who will issue a Nonconformance Report (QAP-15-1). Copies of this form shall be sent to the Group Leader, Assistant Group Leader, and the person responsible for the item in question. Response to the nonconformance and documentation are covered in QAP-16. 
Rev: 0

page 2. of . 2

September 18, 1987

\section{Nonconformance Report}

\section{Description of Situation}

Reported by:

Date:

\section{Requirement Vlolated}

\section{Response}

Responsible party:

Date:

Response Verifled and Accepted

By:

Date:

Form QAP-15-1. 
Revi 1

page 1 of 1 .

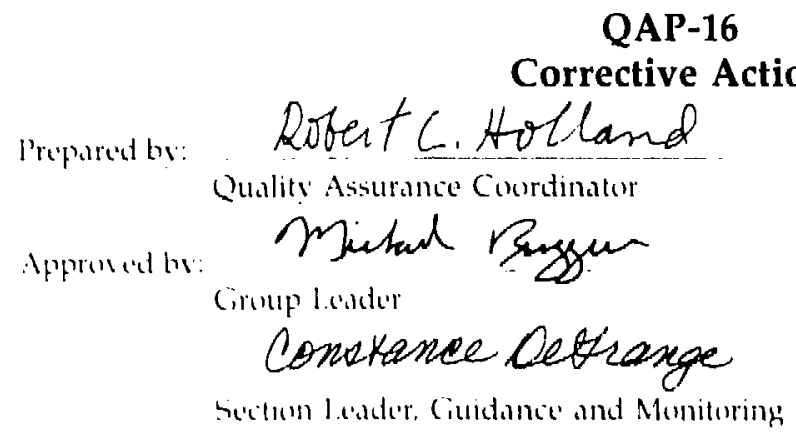

September 18, 1987

\section{Corrective Action}

\section{Requirement}

ANSI/ASME NQA-1-1986: Conditions adverse to quality shall be identified promptly and corrected as soun as practical. In the case of a significant condition adverse to quality, the cause of the condition shall be determined and corrective action taken to preclude recurrence. The identification, cause, and corrective action for significant conditions adverse to quality shall be documented and reported to appropriate levels of management; follow-up action shall be taken to verify implementation of this corrective action.

\section{Response}

Nonconformances are identified as described in QAP-15. All Nonconformance Reports must be responded to in writing within 30 days of the issuance of the Nonconformance Report. The Quality Assurance Coordinator is responsible for verification of the implementation of the corrective action specified on the Nonconformance Report

Deficiencies noted during the annual audits performed by the LLNL, QA Office will be formally responded to by the Section Leader of Guidance and Monitoring.

All completed Nonconformance Reports (which will include the corrective action and verification of the corrective action) shall be archived in the Document Retention Center. 


\section{Quality Assurance Records}

Prepared by:

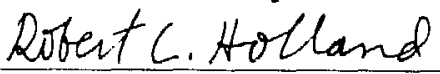

Quality Assurance Coordinator

Approved by:

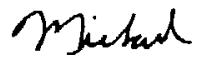

Group Leader

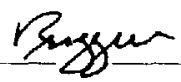

Conotance Detirange

Section Leader. Guidarice and Monitoring

\section{Requirement}

ANSI/ASME NQA-1-1986: Records that furnish documentary evidence of quality shall bu specified, prepared, and maintained. Records shall be legible, identifiable, and retrievable. Reccrds shall be protected against damage, deterioration, or loss. Requirements and responsibilities for record transmittal, distribution, retention, maintenance, and disposition shall be established and documented.

\section{Response}

Procedures that produce QA records will specify in the Documentation section which documents are QA records, and specify method, length, and place of storage.

A list of Quality Assurance Records will be maintained in the Document Retention Center.

The Document Control Coordinator will be responsible for the functioning of the Document Retention Center, including the establishment of a filing system to ensure retrievability. The furictioning of the Document Retention Center shall be detailed in written procedures as specified in QAP-5 and QAP-6. 
Rev. (0

page _ 1 of _. 1. .

QAP-18

Suptember 18, 1987

\section{Audits}

Prepared by:

Rotert C. Hotland

Quality Assurance Coordinator

Approved by:

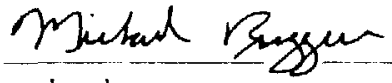

Group Leader

Conatance Detraxge

Section Leder, Guidance and Monitoring

\section{Requirement}

ANSI/ASME NQA-1-1986: Planned and scheduled audits shall be performed to verify compliance with all aspects of the quality assurance program and to determine its effectiveness. These audits shall be performed in accordance with written procedures and checklists by personnel who do not have direct responsibility for performing the activities being audited. Audit results shall be documented and reported to and reviewed by responsible management. Follow-up action shall be taken where indicated.

\section{Response}

An annual audit of this Quality Assurance Plan shall be performed by the LLNL Quality Assurance Office, in accordance with their procedures. This audit will be performed for the Section Leader of the Guidance and Monitoring Section.

In addition, the EQVG Quality Assurance Coordinator will perform assessments of the various EQVG functions in such a manner that all functions are assessed annually. These assessments will be performed in accordance with written procedures, and the results will be retained in the Document Retention Center as specified in QAP-17.

The functions of EQVG Quality Assurance personnel shall be specified in written procedures. 


\section{References}

American National Standards Institute/American Society of Mechanical Engineers (1986). (Uality Assiir-

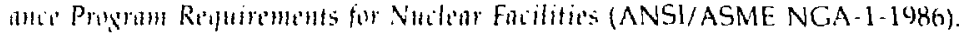

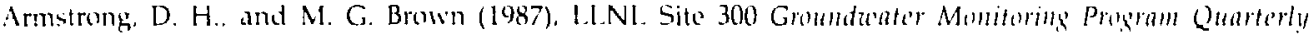
Riport lamary-Mardh 1987. Lawrence livermore National Laboratory, livermore, Calif. (UCAR$10191-87 \cdot 1)$.

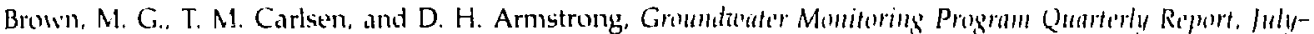
Siptembir 1987, L awrence livermore National Laboratory, Livermore, Calif. (UCAR-10191-87-3).

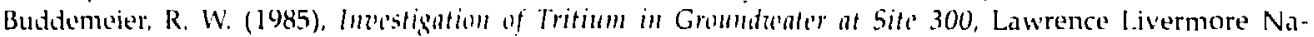
tional Laboratory: Livermore, Calif. (UCID-20600).

Buddemeier, R. W.. D. H. Armstrong, M. G. Brown (1987a), LLNL Site 300 Grounduater Monituring Pregrtam Quarterly Repurt. April-hun' 1987, Lawrence Livermore National Laboratory, Livermore, Calif. (ULAR-10191-87-2)

Butdemeicr. R. W., M. R. Ruggieri, and J. A. Oberdorfer (1987b), Tritium in Grombanater at Sitt 300 , l.awrence lifiermore National Lahoratory, Livermore, Calif. (UCID-21031).

Butdemeier, R. W., D. W. Carpenter and M. R. Ruggieri (1987c). LLNL Site 300 Lmirmmental Ime'stignpiells (Lwarforly, Lawrence Livermore National Lahoratory, Livermore, Calif. (UCAR-10194-87-1).

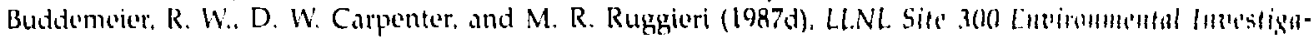
tans (Ualkerly, Lawrence livermore National Laboratory, Livermore, Calif. (UCAR-10194-87-2).

Corlien, T. M., N. G. Brown, D. H. Armstrong (1987), Sile 300 Gromduater Monituring Progrmm. Quartorly

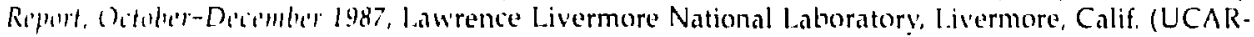
$1(0101-87-4)$.

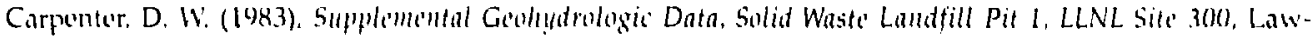
remce Livermore National laboratory: livermore Calif. (UCID-20009).

Carpenter. D. W. R. Slone, R. C. Ragaini, W. A, McConachie, N. B. Crow, and R. Elwood (1983), Assoss-

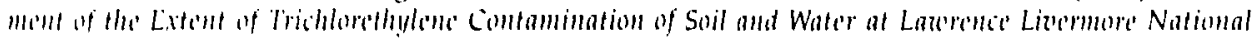
Laburahry, Lawrence Livermore National Lahoratory, Livermore, Calif. (UCID-19945).

Carpenter. D. W. (108t). Assi'ssment of Combmination in Soils and Gromd Water at Lawerence Linermore Vatimal Labuatury. Sandia National Labouatories, Linermore and Adjac'nt Propertie's, Lawrence Livermore National Laboratory, Livermore, Calif. (UCAR-10160).

Carpenter. D. W. I. I. Sweeney. F. W. Kasameyer, N. R. Burkhard, K. G. Knauss, and R. J. Shelmon (1984),

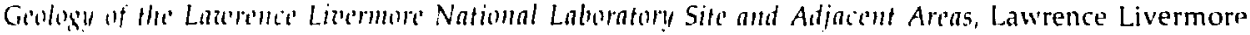
National Laboratory: Livermore, Calif. (UCRL-53316).

Carpenter. D. W., R. Elwood, and L. G. Gross (1986), Ass'ssme'nt of the Extent of Trichlorethyl'me in Soil and Water at Lawrinc' Liw'rmon' National Lahoratory Site 300, Lawrence Livermore National Laboratory, l.ivermore, Calif. (UCID-20774).

City of Livermore (1984), City of Livermore Municipal Code, Ch. 13.

Crow, N., R. Elwood, and $\Gamma$. Webster-Scholten (1986), Distrilution of High Explosite's Compounds in Soil and Walcer at 806/807 Lagouls. HE Proce'ss Arta, LLNL, 5itc 300, Law'rence Livermore National Laborators: Livermore, Calif. (UCAR-10169).

Devany, R. O., W. A. McConachie, D N. Homan, E. M. Nichols, M. D. Dresen, and D. S. Thompson (1997), LLVL Ground Water Project Mouthly Progress Report, January 15-Fibriary 15, 1987, Lawrence Livermore National Lahoratory, Livermore, Calif. (UCAR-10160-87-3).

Devlin, T. K. (1988), Envirommental Monitoring Report, Sandia National Laboratories, Livermore, Sandia National Laboratories, Livermore, Calif. (SAND 88-8206).

Dibblee, T. W. Jr. (1980), A Preliminary Map of the Midway Quadrangle, Alameda and San loapuin Conutir's, Colifomia, USGS Open-File Report 80-535.

Dreicer, M. (1985). Preliminary Report on the Past and Presemt Use's, Storage, and Disposal of Hazardous

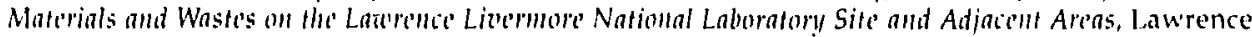
Livermore National Laboratory, Livermore, Calif, (UCRL-20442).

Dresen, M. D., and E. M. Nichols (1986), Distrihution of VOCs in Gromid Water We'sl of LLNL, Lawrence Livermore National Lahoratory, Livermore, Calif. (UCID-20917). 


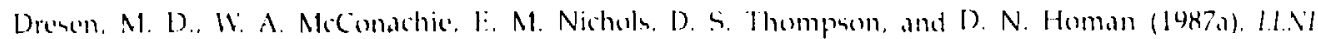

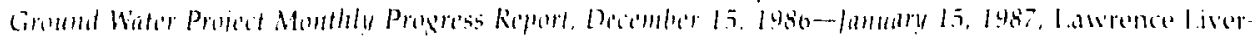
more National laboratory, livermore, Calif. (UCAR-10160) 87.2 ).

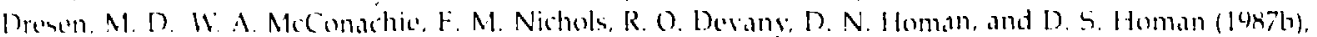

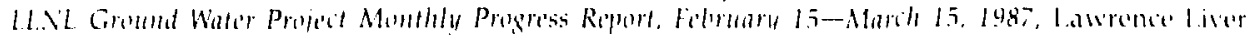

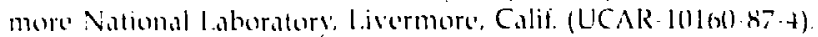

Dresen, M. D. W. A. McComachie, R. O. Devany, M. C. Small, D. 5. Thomponen, and D. N. Homan (1987a),

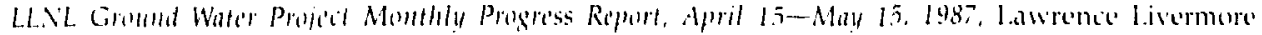
National laboratory: lisermore, Calit. (UCAR-1016()-87-6).

Dresen. M. D., W. A. MeConathie, R. O. Devany, E. M. Nichols, M. C. Small. D. 5. Thompsi n, and D. N

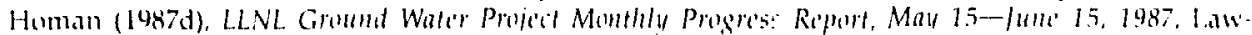

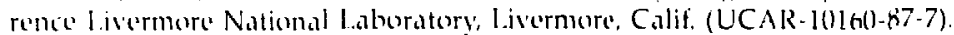

Drincll, M. D., E. N. Nichols, R. O. Devany, W. F. Isherwend, D. S. Thompsion, M. C. Small, and D. N.

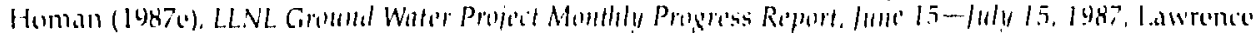
l.isermoro National I.aboratory l.ivermore, Calif. (UCAR-1016(6)-87.8).

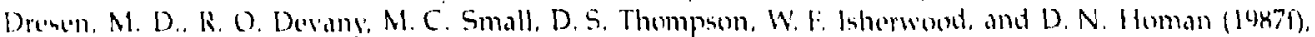

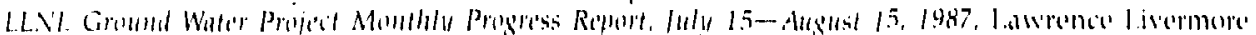

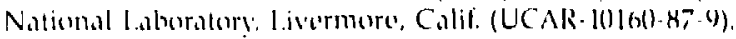

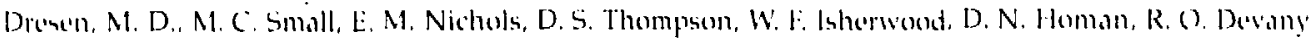

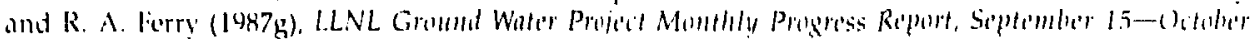
15, 1987. Lawrence livermore National l.aboratory, livermore, Calif, (UCAR-1016()-87-11).

Drestill, N. D., E. M. Nichols, W. A. M.Comachie, K. S. Buchanan, and W. LE Lsherwood (1987h), Re'medial

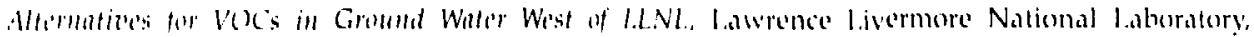
I.jurmore, Calif. (Draft meport, UCAR-102()2).

Fishuer. I. C. Ir. (1976), "Calibration of Andersen-Braun Remmeters with Track Eteh Detectors," Hazarts

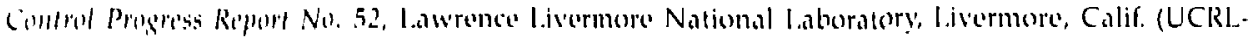
S(1)(1)7-76-1).

Gatrisom. 1., 5. Mackean, R. Bocanegra, and R. W. Buddemeier (1985), Radiochemical Methods of the Site Ensirommental Monitoring Program, Lawrence Livermore National Laboratory, Livermore, Calif. (M-122. Rev: 1).

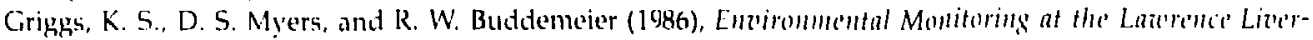

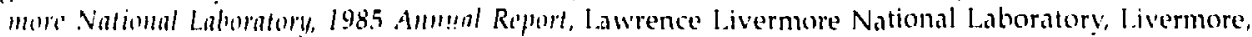
Calif. (UCRL.-50027-85).

Gudiksen, Г. H. C. I. Lindeken, J. W. Meadows, and K. O. Hamby (1973), Lumbumental Lizels of Radionitivity in the Vicinity of th' LLL, 1972 Ammal Report. Lawrence Livermore National lahoratory, l.ivermore, Calif. (UCRI.5I333).

Holland, R. C., R. W. Buddemeir, D. D. Brekke (1987), Envirommental Monitoring at the Laterence Litermore' Vational Labmaturl 1986 Ammal Rephlt, Lawrence Livermore National Laboratory, Livermore, Calif. (UCAR-50027-86).

International Commission on Radiological Protection (1977), Recommendations of the Intermational Commissicn an Radiolugical Protedion, Publication 26, Pergoman Press, New York.

International Commission on Radiological Protection (1980), Limits for lutake's of Rndionus lide's by Worters, Publication 30, Pergoman Press, New York.

l.indeken, C. L., P. H. Gudiksen, ]. W. Meadows, K. O. Hamby, and L. R. Anspaugh (1963), Emirommonm Le've's of Rationtivity in Lit'irmore Valley/ Solls, Lawrence Livermore National laboratory, l.ivermore, Calif. (UCRL-74+14).

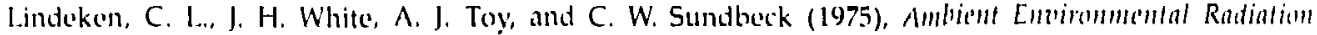
Monitoring at the Law'me' Livermori National Laboratory, Lawrence Livernore National Laboratory, l.juermore, Calif, (UCRL.77106).

Lowter, W. M., and H. L. Beck (1966), "Cosmic Ray lonization in the L.ower Atmosphere," /. Gio), Physt. Ri't: 71, 4611.

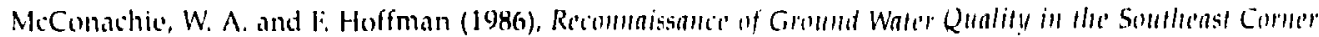
of Laurente Lincrmore National Laboratory, Lawrence Livermore National Laboratory, Livermore, Calif. (UCAR-1016t). 


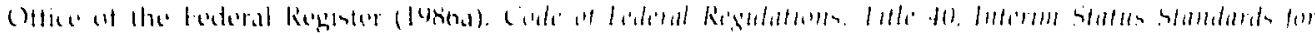

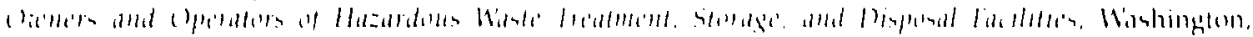
D.C.. Part $26 \overline{7}$

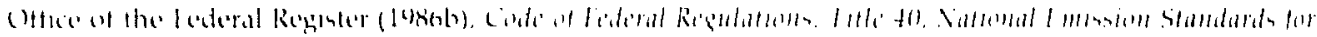

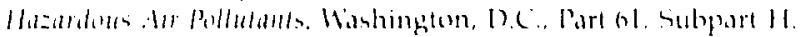

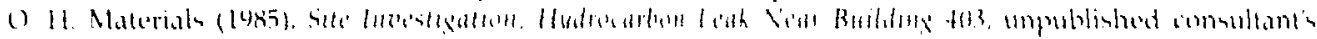

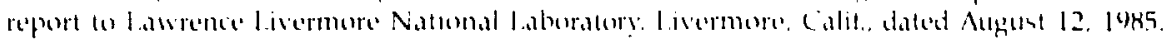

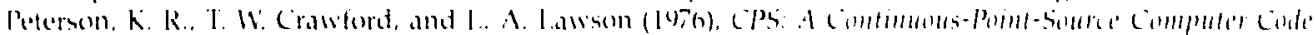

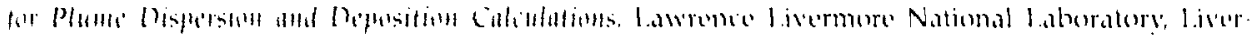
mure, Calif. (LCRL $52(14$ (4)

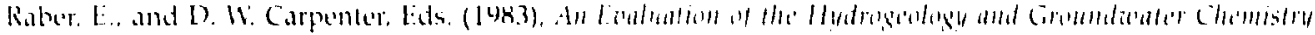

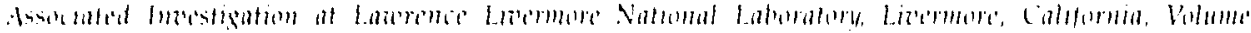

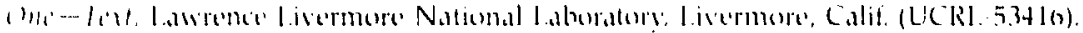

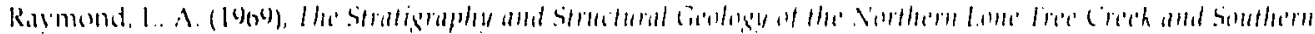

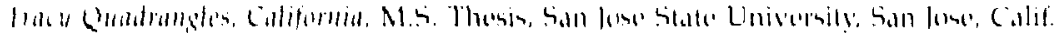

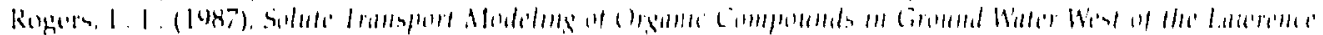

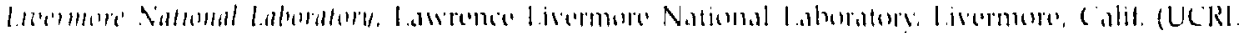
(17.35(3). "P pl.

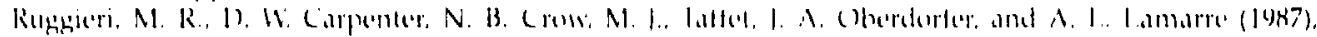

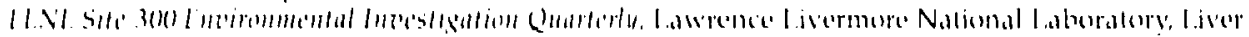
mure, Calif. (UCAR-1114-4.87-3).

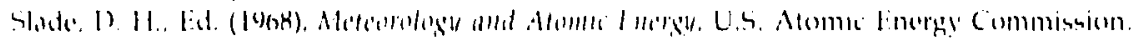

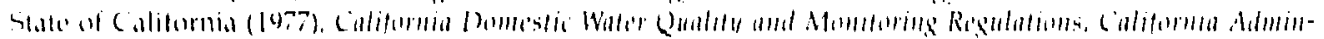

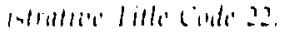

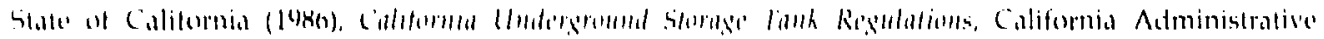
Cinte. Titlo 2.3. Ch. 3. Subthet. 16.

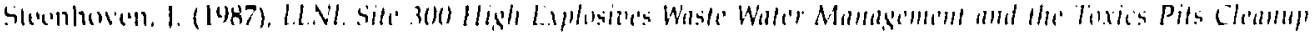

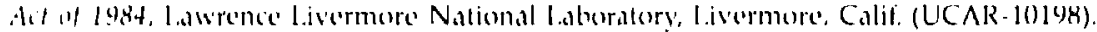

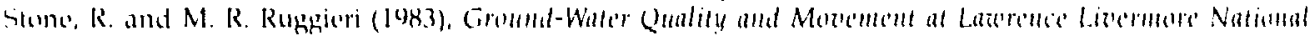

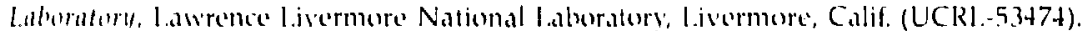

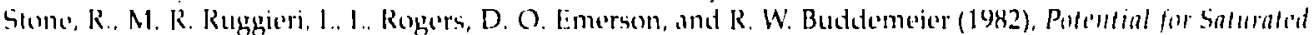

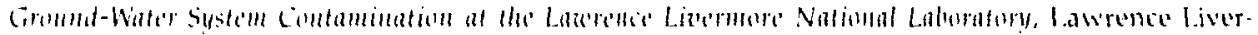
more National Laboralory, livermore, Calif. (UCRI.-53+26).

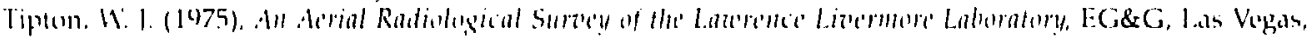
Neviatal (l:CiCi-118.3-160)3).

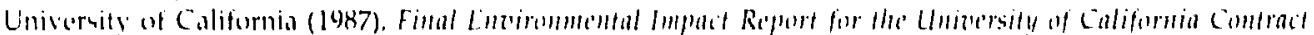

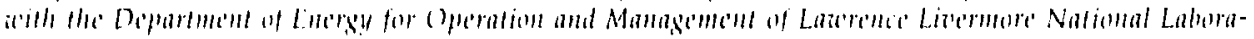
Hary, Lniversily of California, Berkoley, Calif (SCH-85112611).

U.S. Department of linergy (1987a). Radiation Protiction of the Pallis and the Lndirmment. DOE: Order No. 5+80.XX, draft of March 20, 1987, U.S. Department of Energy: Washington D.C.

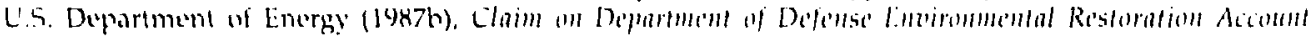
(draft).

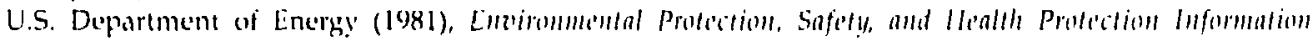
Repurting Reamirments, DOE Order No, 5t80.1 - Chapter 1, U.S. Department of Energy Operational and Environmental Safety Division, Washington D.C.

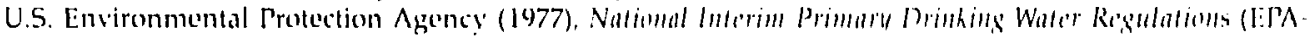
57(0)/4-76-(00)3).

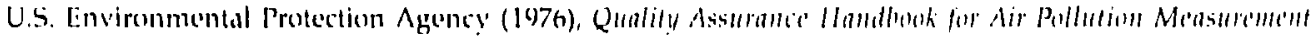
Sy/St'ms (EPA-60)/9-76-(0)(15).

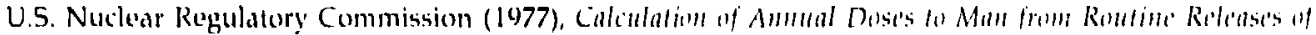

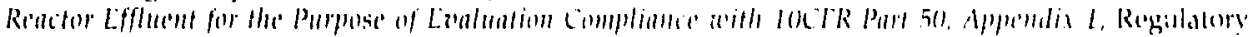
Guido $1.10 \%$.

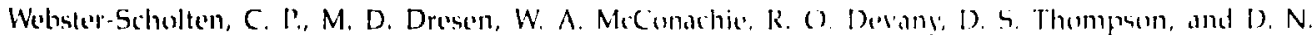

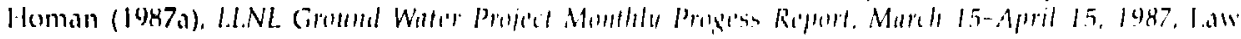

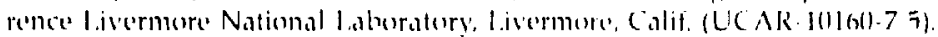


Wehster-Sihulten, C. P., R. O. Devany, E. M. Nichols, W. Y. lsherwood, M. D. Dresen, M. C. Small, D. 5. Thompson, and D. N. Homan (1987b), LLNL Ground Water Proted Monthly Progess Report, August 1.5S'ph'mli'r 15, 1987, Lawrence Livermore National Laboratory, l.jermore, Calif. (UCAR-10160-7-10).

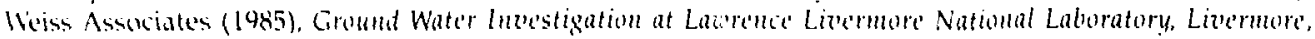

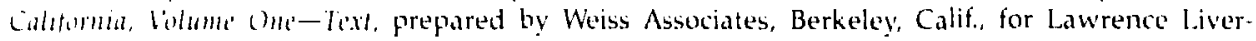
more National Laboratory, Livermore, Calif. (UCRL-15835). 


\section{External Distribution}

11 thim

I inermure Water Redhamation Plant

1250 kitts Hawh Roud

licermore. CA 94530

Assistant Administratur for Air Radiatton (ANR -443)

L.S. Envirommental Protecteon sgency

Wishingtum. D.C. $2(1+4)$

1. Avres

M. Dermer

1. Han

U.S. Environmental Drotectum : Agemes

Region IX

215 fremont Streed

San Francisoc, CA $4+107$

11. Brinkley

Bay Arad Air Quality Nanagement Distrut

Gai) llllin Street

San frandinco. ( 144104

R. F. Brus

Vallecitum Nustear Cinter

Pleasanton. CA 4456h

T. Bursotinsiky

Asseciation of Bay Area Gosermments

P. (). Box 2050

Oakland, CA 4t6014

T. Dewlin

Sandia National laboratories

livermore, $C_{1} 94550$

D. Hoenig

M. James

D. Krause

California Department of Health Services

Toxic Substances Control Division

5850 Shellmound. 3rd floor

Emerville. CA $4460 \mathrm{~s}$

\section{Horner}

City of livernore

City Manager

10525 . livermore $\mathrm{Nie}$

livermore. CA 44530

R. lament

N. Ammann
1) Dilke

P.Mallon

Calfurnia Reguonal Water Quality Control Borard

San Francisco Bay Region

1111 lackson Street, Room 6040)

Onkland $\mathrm{CA} 94607$

1. Killingstad

Nameda Couny litood Contrel District

Ane 7

sest Parknide Drive

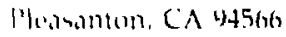

1. 1. I. (1)ahan

Nlamesta County Walter Districl

3singl| fremont B|sid.

Iremunt, CA 945.37

C. Ow'the

(i. Tinrese

Calitumia State Water Resources Control Beard

Divinion of Waler Quality

(2) " $P$ " Stree't

Sacramento, CA 95814

5. Rohertuon

ii. Colson

A. Vorster

California Regional Water Quality Control Board

Central Lalley Region

3443 Rosutior Rd.

hacrumento, CA $95827 \cdot 3098$

T. Shirasawa

Alameda County Health Care Services Ageney

I:nvirommental Health Planning

(7) 27th Strext

()aklant, CA 4 4612

1. O. Ward

Department of Health Services

Radolongic Health Section

7it "p" strent

sacramento, CA 95814

V. V. Williams

San loaguin local Healeh District

P. (7) Bux $2(3) 4$

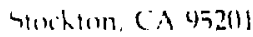

